Prepared in cooperation with the Carson Water Subconservancy District and Nevada Division of Environmental Protection

\title{
Groundwater Contributions to Excessive Algal Growth in the East Fork Carson River, Carson Valley, West-Central Nevada, 2010 and 2012
}

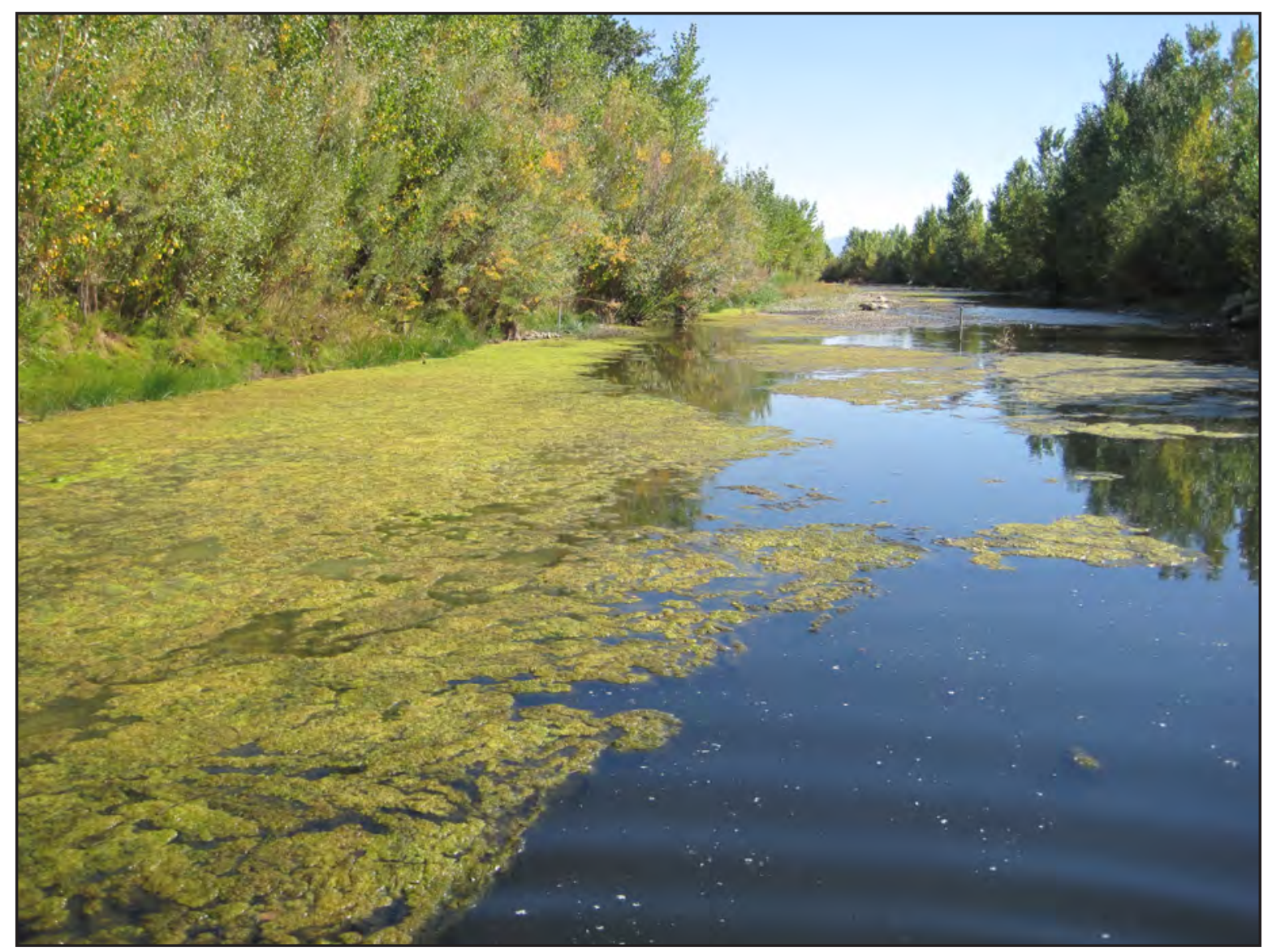

Scientific Investigations Report 2018-5102 


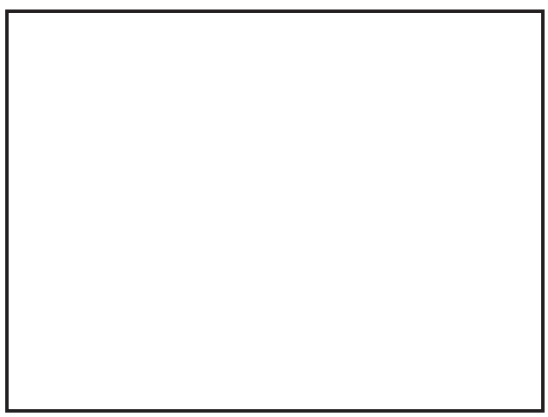

\section{FRONT COVER:}

Photograph showing algae in the East Fork Carson River looking upstreem toward well transect 4 (upper), Carson Valley, west-central Nevada.

Photograph by Nancy Alvarez, U.S. Geological Survey, 2012.

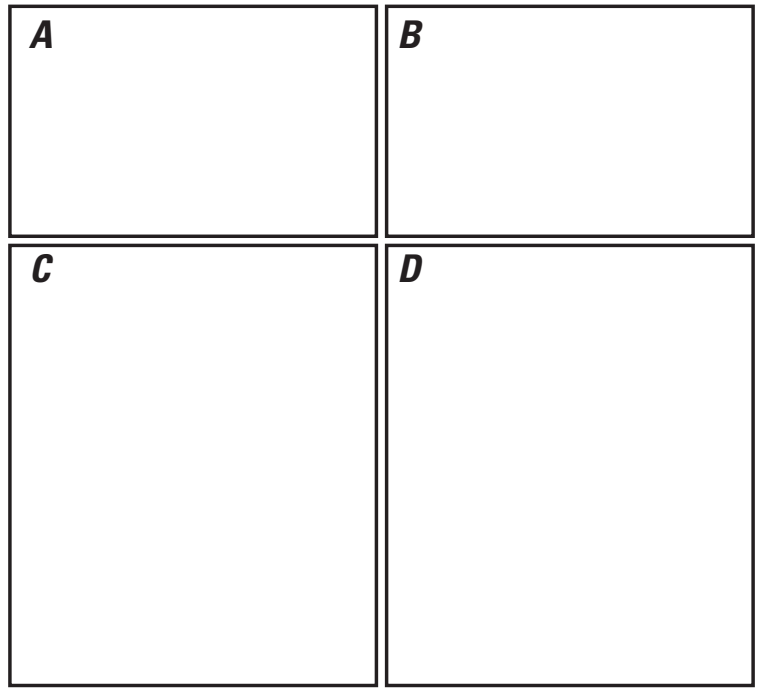

\section{BACK COVER:}

Photographs showing U.S. Geological Survey and Nevada Division of Environmental Protection scientists and engineer performing field work for this study along the East Fork Carson River, Carson Valley, west-central Nevada. Photographs by Nancy Alvarez, U.S. Geological Survey, A, 2010; B, 2012; C, 2010; D, 2012. 


\section{Groundwater Contributions to Excessive Algal Growth in the East Fork Carson River, Carson Valley, West-Central Nevada, 2010 and 2012}

By Nancy L. Alvarez, Randy A. Pahl, and Michael R. Rosen

Prepared in cooperation with the Carson Water Subconservancy District and Nevada Division of Environmental Protection

Scientific Investigations Report 2018-5102 


\title{
U.S. Department of the Interior \\ RYAN K. ZINKE, Secretary
}

\author{
U.S. Geological Survey \\ James F. Reilly II, Director
}

U.S. Geological Survey, Reston, Virginia: 2018

For more information on the USGS - the Federal source for science about the Earth, its natural and living resources, natural hazards, and the environment-visit https://www.usgs.gov or call 1-888-ASK-USGS.

For an overview of USGS information products, including maps, imagery, and publications,

visit https://store.usgs.gov.

Any use of trade, firm, or product names is for descriptive purposes only and does not imply endorsement by the U.S. Government.

Although this information product, for the most part, is in the public domain, it also may contain copyrighted materials as noted in the text. Permission to reproduce copyrighted items must be secured from the copyright owner.

Suggested citation:

Alvarez, N.L., Pahl, R.A, and Rosen, M.R., 2018, Groundwater contributions to excessive algal growth in the East Fork Carson River, Carson Valley, west-central Nevada, 2010 and 2012: U.S. Geological Survey Scientific Investigations Report 2018-5102, 94 p., https://doi.org/10.3133/sir20185102. 


\section{Acknowledgments}

Funding for this project was provided by Nevada Division of Environmental Protection, the Carson Water Subconservancy District (CWSD), and the U.S. Geological Survey (USGS).

Appreciation is extended to homeowners and landowners who allowed access to the East Fork Carson River from their property. Many thanks to Ed James (CWSD), Genie Azad (formerly of CWSD), and the CWSD students for logistical support and help in the field. A special thank you goes to Mike Potts, formerly a student at the USGS, for going above and beyond the call of duty by staying up all night to collect groundwater samples and for collecting a large portion of the field data in 2010. Many thanks also go to current and former USGS employees Lindsay Burt, Toby Welborn, Mike Barrenchea, Jonathan Arthur, Karen Thomas, and Kurtiss Schmidt for their help in the field, and to Sonya Vasquez, James Swartwood, Kip Allander, Toby Welborn, and Rose Medina for their help with data management, processing and analyzing the data, and creating figures, and to Dan Bright, Dave Berger, Steve Berris, Angi Paul, Kip Allander, Shannon Watermolen, Chris Mebane, and Andrew Gendaszek for reviews of draft manuscripts. Special thanks goes to Nancy Damar, of the USGS, for preparing the data release associated with this report. 


\section{Contents}

Acknowledgments .......................................................................................................................ii

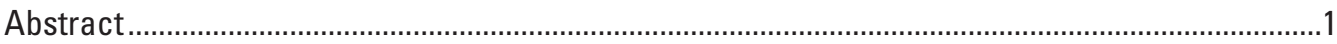

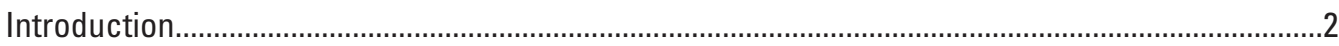

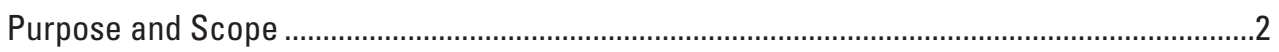

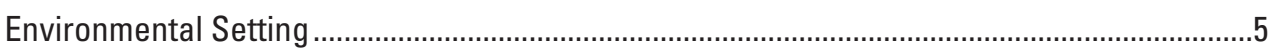

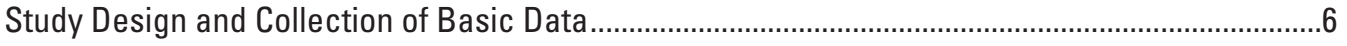

Methods of Data Analysis .....................................................................................................

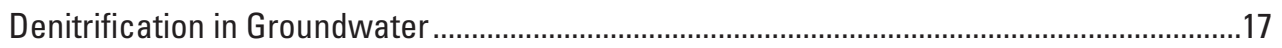

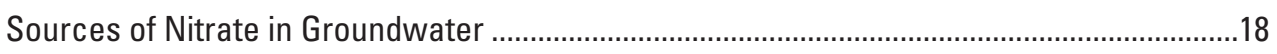

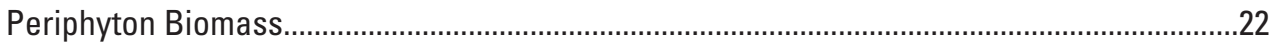

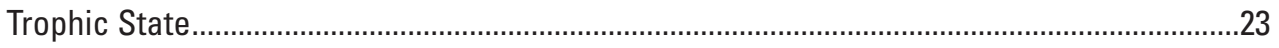

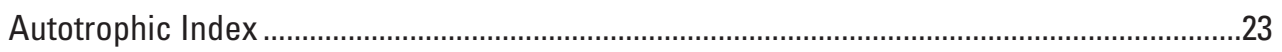

Comparison of Water-Quality Data to Standards and Reference Criteria ..............................23

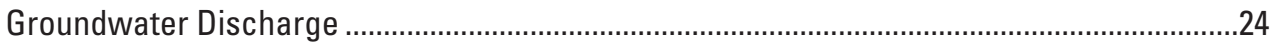

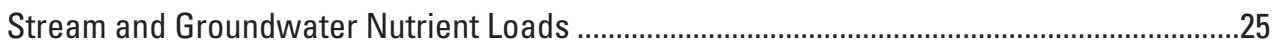

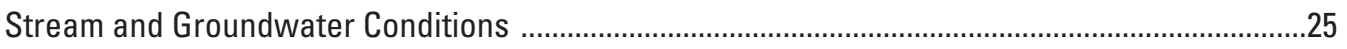

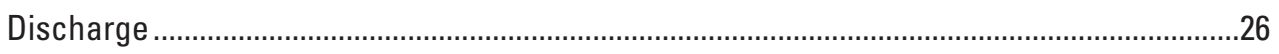

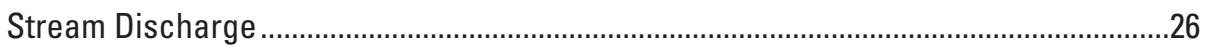

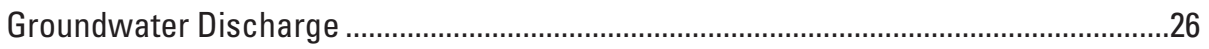

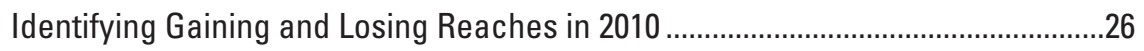

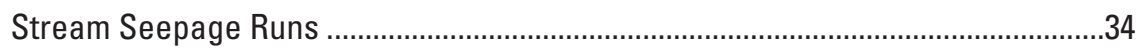

Chloride Mass Balance .........................................................................................

Specific Conductance Profiles ................................................................................

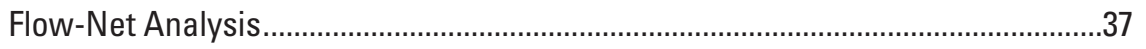

Summary of Groundwater Discharge Estimates ....................................................38

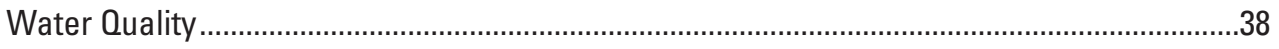

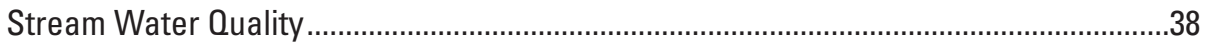

Comparison to Historical Water Quality ………………….....................................44

Comparison to Water-Quality Standards and Reference Criteria ............................46

Groundwater Quality .............................................................................................49

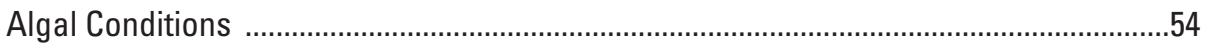

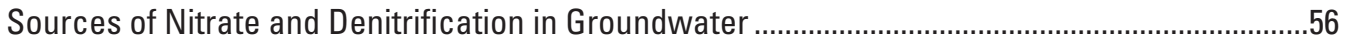

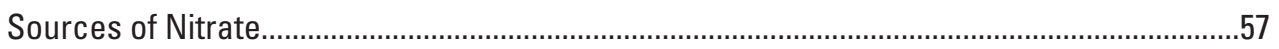

Evidence from Detection of Organic Wastewater Compounds ......................................57

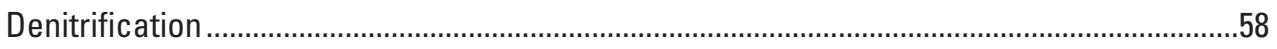

Evidence from Nitrogen and Oxygen Isotopes ………...........................................58

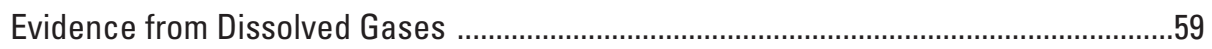

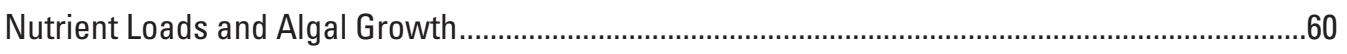

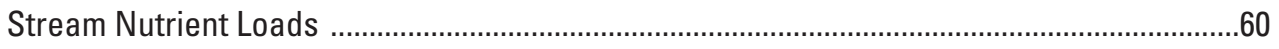

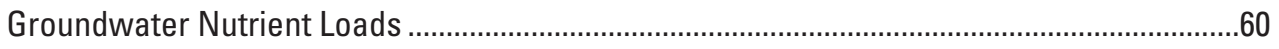

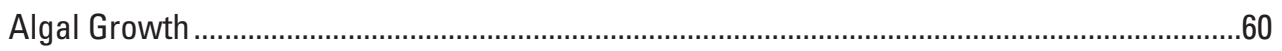

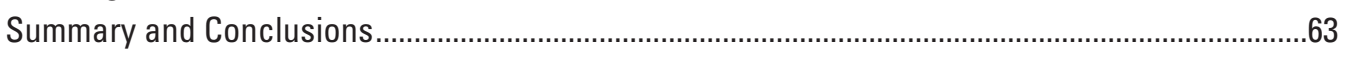

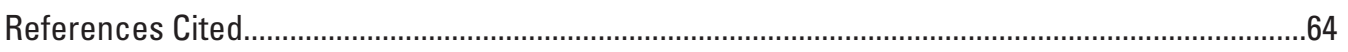


Appendix 1. Field Measurements and Nutrient and Chloride Concentrations in Stream and Groundwater Samples Collected Along the East Fork Carson River, 2010,

Carson Valley, West-Central Nevada.

Appendix 2. Field Measurements and Nutrient, Chloride, Dissolved Organic Carbon, and Isotope Concentrations in Stream and Groundwater Samples Collected Along the East Fork Carson River, 2012, Carson Valley, West-Central Nevada 79

Appendix 3. Quality Assurance and Quality Control Procedures for Water-Quality Samples........87

2010 Nutrient and Chloride Quality Control Samples ...........................................................87

2012 Nutrient, Chloride, and Dissolved Organic Carbon Quality Control Samples ..................87

2012 Dissolved-Gas and Nitrogen and Oxygen Isotope Quality Control Samples ...................87

2012 Organic Wastewater Compounds Quality Control Samples.............................................88

Appendix 4. Dissolved-Gas Concentrations, Assumed Recharge Elevation, Calculated

Recharge Temperature, and Excess Air for Samples of Water From Select

Groundwater Wells Located In and Near the East Fork Carson River, 2012,

Carson Valley, West-Central Nevada.

Appendix 5. Organic Wastewater Compound Concentrations for Blank, Replicate, and

Environmental Samples From Select Groundwater Wells Located In and Near the

East Fork Carson River, 2012, Carson Valley, West-Central Nevada .. .91

\section{Figures}

1. Map showing location of study area on the East Fork Carson River, Carson Valley, west-central Nevada .

2. Map showing stream temperature data for the East Fork Carson River, midafternoon on August 8, 2006, Carson Valley, west-central Nevada

3. Photograph showing small drainage channel formed by storm or snowmelt runoff discharging from a storm drain that connects to the stream site East Fork Carson River near Muller Lane middle-stream transect (SMT), Carson Valley, west-central Nevada

4. Graph showing mean monthly discharge for water years 1975-84 and 1995-98 at East Fork Carson River at Minden (U.S. Geological Survey stream gaging station 10309100), Carson Valley, west-central Nevada

5. Map showing location of data collection sites including three well transects and three stream sites, as part of a reconnaissance study (2010) along the study reach of the East Fork Carson River, Carson Valley, west-central Nevada

6. Map showing location of data collection sites including three well transects and three stream sites, as part of the investigative study (2012) along the study reach and subreach of the East Fork Carson River, Carson Valley, west-central Nevada.

7. Photograph showing water-quality sonde deployment at stream site East Fork Carson River near Muller Lane downstream transect (SDT), East Fork Carson River, Carson Valley, west-central Nevada...

8. Graphs showing water-level altitudes in observation wells and the stream at well transects, summer 2010, East Fork Carson River, Carson Valley, west-central Nevada..

9. Graphs showing vertical hydraulic gradients between streambank wells and stream and between mid-stream well and stream at well transect 2 (middlestream), summer 2010, East Fork Carson River, Carson Valley, west-central Nevada ...30

10. Graphs showing water temperature at well transects and stream sites of the East Fork Carson River, Carson Valley, west-central Nevada, July and August 2010.....31 


\section{Figures-Continued}

11. Graphs showing water temperature at well transects and stream sites of the East Fork Carson River, Carson Valley, west-central Nevada, September 2010

12. Graph showing longitudinal stream profiles of specific conductance along the study reach from above the stream site East Fork Carson River near Muller Lane upstream transect (SUT) to below the stream site East Fork Carson River near Muller Lane downstream transect (SDT) and includes stream site East Fork Carson River near Muller Lane middle-stream transect (SMT), August 2, 2012, and

September 25, 2012, East Fork Carson River, Carson Valley, west-central Nevada ........36

13. Graph showing relative proportion of reach streamflow originating from groundwater discharge along the study reach for specific conductance profiles collected from above the stream site East Fork Carson River near Muller Lane upstream transect (SUT) to below the stream site East Fork Carson River near Muller Lane downstream transect (SDT) and includes the stream site East Fork Carson River near Muller Lane middle-stream transect (SMT), on August 2 and September 25, 2012, East Fork Carson River, Carson Valley, west-central Nevada ........36

14. Graphs showing water temperature, $\mathrm{pH}$, dissolved oxygen, and specific conductance at stream site East Fork Carson River near Muller Lane downstream transect (SDT), August 3-September 29, 2010, and July 20-August 17, 2012, East Fork Carson River, Carson Valley, west-central Nevada.

15. Graph showing daily fluctuation in dissolved oxygen and $\mathrm{pH}$, July 21-31, 2012, at stream site East Fork Carson River near Muller Lane downstream transect (SDT), East Fork Carson River, Carson Valley, west-central Nevada.

16. Graphs showing nitrogen, phosphorus, and dissolved oxygen concentrations at the reconnaissance study well transect 2 (middle-stream) observation wells.

17. Graph showing chloride concentrations at the reconnaissance study well transect 2 (middle-stream) right bank (MRB6), mid-stream (MMS5), and left bank (MLB4) observation wells, September 8-9, 2010, East Fork Carson River, Carson Valley, west-central Nevada

18. Graphs showing average concentrations of dissolved oxygen, dissolved nitrate plus nitrite, and dissolved orthophosphate in observation wells at well transect 4 (upper), well transect 2 (middle-stream), and well transect 5 (lower), summer 2012, East Fork Carson River, Carson Valley, west-central Nevada

19. Graph showing chlorophyll a concentrations from five sampling events at stream sites in 2010 and 2012, East Fork Carson River, Carson Valley, west-central Nevada ....56

20. Photograph showing high algal biomass at stream site East Fork Carson River near Muller Lane middle-stream transect (SMT), July 23, 2012, East Fork Carson River, Carson Valley, west-central Nevada

21. Graph showing $\delta^{15} \mathrm{~N}$ and $\delta^{18} 0$ compositions of nitrate in groundwater samples collected from select wells in Douglas County, Carson Valley, west-central Nevada ...58

22. Graph showing $\delta^{15} \mathrm{~N}_{\text {nitrate }}$ and nitrate plus nitrite concentrations in groundwater samples collected from select groundwater wells at well transect 2 (middle-stream), well transect 4 (upper), and well transect 5 (lower), 2012, East Fork Carson River, Carson Valley, west-central Nevada. 


\section{Tables}

1. Description of stream sites, observation wells, and types of data collected in 2010 and 2012, East Fork Carson River, Carson Valley, west-central Nevada

2. Distances between stream and groundwater sites in study reach, 2010 and 2012, East Fork Carson River, Carson Valley, west-central Nevada.

3. Summary of basic hydrologic data collected along East Fork Carson River study reach in 2010 and study reach and subreach in 2012, Carson Valley, west-central Nevada

4. Organic wastewater compounds analyzed in groundwater samples collected from select groundwater wells at well transect 4 (upper), well transect 2 (middlestream), and well transect 5 (lower), 2012, including their uses or sources and their reporting levels, East Fork Carson River, Carson Valley, west-central Nevada.

5. Summary of trophic-state classification scheme used for samples collected from the East Fork Carson River in Carson Valley, west-central Nevada ...

6. Summary of discharge measurements at stream sites and net streamflow gain or loss attributed to groundwater for the 2010 and 2012 studies, East Fork Carson River, Carson Valley, west-central Nevada

7. Streamflow, chloride concentration, and estimated groundwater discharge based on the chloride mass balance method, 2010 and 2012, East Fork Carson River, Carson Valley, west-central Nevada

8. Site numbers, slug test information, and estimates of hydraulic conductivity at select observation wells, 2010 and 2012, East Fork Carson River, Carson Valley, west-central Nevada

9. Parameters used to calculate groundwater discharge to the study subreach using flow-net analysis, 2012, East Fork Carson River, Carson Valley, west-central Nevada

10. Summary of stream water-quality and groundwater-quality data collected in summers 2010 and 2012, East Fork Carson River, Carson Valley, west-central Nevada

11. Summary of minimum, median, and maximum concentrations of selected constituents sampled at historic Nevada Division of Environmental Protection sites and at study stream sites in summer 2010 and summer 2012, East Fork Carson River, Carson Valley, west-central Nevada.

12. Nevada Division of Environmental Protection stream water-quality standards for selected constituents. 


\section{Tables-Continued}

13. Summary of exceedances of the State of Nevada temperature water-quality standard at stream site East Fork Carson River near Muller Lane downstream transect (SDT), 2010 and 2012, East Fork Carson River, Carson Valley, west-central Nevada

14. Summary of exceedances of the State of Nevada dissolved oxygen water-quality standard at stream site East Fork Carson River near Muller Lane downstream transect (SDT), 2010 and 2012, East Fork Carson River, Carson Valley, west-central Nevada

15. Summary of exceedances of the State of Nevada dissolved oxygen saturation guideline at stream site East Fork Carson River near Muller Lane downstream transect (SDT), 2010 and 2012, East Fork Carson River, Carson Valley, west-central Nevada

16. Summary of exceedances of the State of Nevada pH water-quality standard at stream site East Fork Carson River near Muller Lane downstream transect (SDT), 2010 and 2012, East Fork Carson River, Carson Valley, west-central Nevada.

17. Chlorophyll a, algal biomass, algal biomass to chlorophyll a ratio, and percent algal cover for stream sites, East Fork Carson River, 2010 and 2012, Carson Valley, west-central Nevada

18. Trophic status for stream sites, 2010 and 2012, based upon mean and maximum chlorophyll a levels, East Fork Carson River, Carson Valley, west-central Nevada .........56

19. Nutrient loads in groundwater and the stream in study reach, 2012, East Fork Carson River, Carson Valley, west-central Nevada

1-1. Field measurements and nutrient and chloride concentrations in stream and groundwater samples collected along the East Fork Carson River, 2010, Carson Valley, west-central Nevada...

2-1. Field measurements and nutrient, chloride, dissolved organic carbon, and isotope concentrations in stream and groundwater samples collected along the East Fork Carson River, 2012, Carson Valley, west-central Nevada

4-1. Dissolved-gas concentrations, assumed recharge elevation, calculated recharge temperature, and excess air for samples of water from select groundwater wells located in and near the East Fork Carson River, 2012, Carson Valley, west-central Nevada

5-1. Organic wastewater compound concentrations for blank, replicate, and environmental samples from select groundwater wells located in and near the East Fork Carson River, 2012, Carson Valley, west-central Nevada. 


\section{Conversion Factors}

U.S. customary units to International System of Units

\begin{tabular}{|c|c|c|}
\hline Multiply & By & To obtain \\
\hline \multicolumn{3}{|c|}{ Length } \\
\hline inch (in.) & 2.54 & centimeter $(\mathrm{cm})$ \\
\hline foot $(\mathrm{ft})$ & 0.3048 & meter $(\mathrm{m})$ \\
\hline mile (mi) & 1.609 & kilometer (km) \\
\hline yard (yd) & 0.9144 & meter $(\mathrm{m})$ \\
\hline \multicolumn{3}{|c|}{ Area } \\
\hline acre & 4,047 & square meter $\left(\mathrm{m}^{2}\right)$ \\
\hline square foot $\left(\mathrm{ft}^{2}\right)$ & 929.0 & square centimeter $\left(\mathrm{cm}^{2}\right)$ \\
\hline square foot $\left(\mathrm{ft}^{2}\right)$ & 0.09290 & square meter $\left(\mathrm{m}^{2}\right)$ \\
\hline square inch $\left(\mathrm{in}^{2}\right)$ & 6.452 & square centimeter $\left(\mathrm{cm}^{2}\right)$ \\
\hline \multicolumn{3}{|c|}{ Volume } \\
\hline ounce, fluid (fl. oz) & 0.02957 & liter (L) \\
\hline pint (pt) & 0.4732 & liter (L) \\
\hline quart (qt) & 0.9464 & liter (L) \\
\hline gallon (gal) & 3.785 & liter (L) \\
\hline cubic inch $\left(\mathrm{in}^{3}\right)$ & 0.01639 & liter (L) \\
\hline cubic foot $\left(\mathrm{ft}^{3}\right)$ & 28.32 & cubic decimeter $\left(\mathrm{dm}^{3}\right)$ \\
\hline cubic foot $\left(\mathrm{ft}^{3}\right)$ & 0.02832 & cubic meter $\left(\mathrm{m}^{3}\right)$ \\
\hline \multicolumn{3}{|c|}{ Flow rate } \\
\hline cubic foot per second $\left(\mathrm{ft}^{3} / \mathrm{s}\right)$ & 0.02832 & cubic meter per second $\left(\mathrm{m}^{3} / \mathrm{s}\right)$ \\
\hline \multicolumn{3}{|c|}{ Mass } \\
\hline ounce, avoirdupois (oz) & 28.35 & $\operatorname{gram}(\mathrm{g})$ \\
\hline pound, avoirdupois (lb) & 0.4536 & kilogram (kg) \\
\hline \multicolumn{3}{|c|}{ Pressure } \\
\hline atmosphere, standard (atm) & 101.3 & kilopascal (kPa) \\
\hline bar & 100 & kilopascal (kPa) \\
\hline inch of mercury at $60^{\circ} \mathrm{F}$ (in $\mathrm{Hg}$ ) & 3.377 & kilopascal $(\mathrm{kPa})$ \\
\hline pound-force per square inch $\left(\mathrm{lbf} / \mathrm{in}^{2}\right)$ & 6.895 & kilopascal (kPa) \\
\hline pound per square foot $\left(\mathrm{lb} / \mathrm{ft}^{2}\right)$ & 0.04788 & kilopascal (kPa) \\
\hline pound per square inch $\left(\mathrm{lb} / \mathrm{in}^{2}\right)$ & 6.895 & kilopascal (kPa) \\
\hline \multicolumn{3}{|c|}{ Hydraulic conductivity } \\
\hline foot per day (ft/d) & 0.3048 & meter per day $(\mathrm{m} / \mathrm{d})$ \\
\hline
\end{tabular}


Temperature in degrees Celsius $\left({ }^{\circ} \mathrm{C}\right)$ may be converted to degrees Fahrenheit $\left({ }^{\circ} \mathrm{F}\right)$ as follows:

$$
{ }^{\circ} \mathrm{F}=\left(1.8 \times{ }^{\circ} \mathrm{C}\right)+32 .
$$

\section{Datum}

Vertical coordinate information is referenced to the North American Vertical Datum of 1988 (NAVD 88).

Horizontal coordinate information is referenced to the North American Datum of 1983 (NAD 83).

Altitude, as used in this report, refers to distance above the vertical datum.

\section{Supplemental Information}

Specific conductance is given in microsiemens per centimeter at 25 degrees Celsius $(\mu \mathrm{S} / \mathrm{cm}$ at $\left.25^{\circ} \mathrm{C}\right)$.

Concentrations of chemical constituents in water are given in either milligrams per liter (mg/L) or micrograms per liter $(\mu \mathrm{g} / \mathrm{L})$.

Groundwater discharge is given in cubic feet per second per mile $\left(\mathrm{ft}^{3} / \mathrm{s} / \mathrm{mi}\right)$.

Chlorophyll a concentrations are given in milligram per square meter $\left(\mathrm{mg} / \mathrm{m}^{2}\right)$.

Nutrient loads are given in pounds per day $(\mathrm{lb} / \mathrm{d})$.

Hydraulic gradient is given in feet per foot $(\mathrm{ft} / \mathrm{ft})$.

Results for measurements of stable isotopes of an element (with symbol E) in water, solids, and dissolved constituents commonly are expressed as the relative difference in the ratio of the number of the less abundant isotope (iE) to the number of the more abundant isotope of a sample with respect to a measurement standard.

The nitrogen and oxygen isotope ratios of nitrate in water samples are given as delta $(\delta)$ values in units of parts per thousand (per mil, \%o) relative to an international reference standard. 

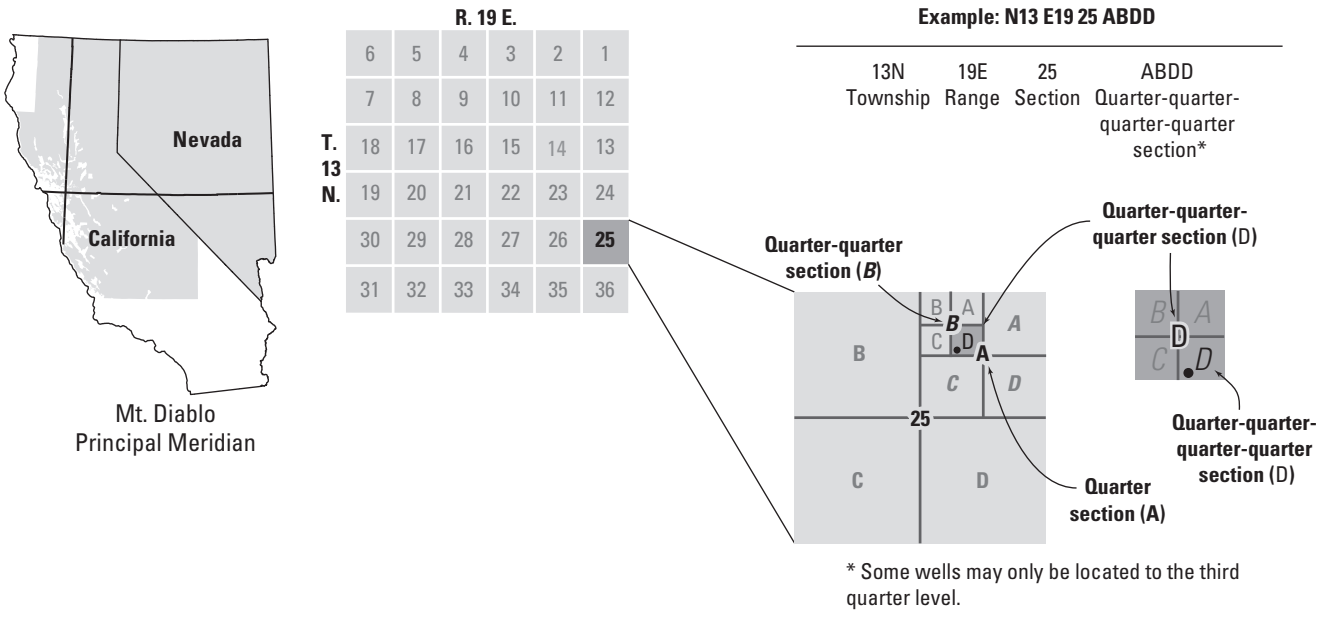

The system of numbering wells and springs in Nevada is based on its location in the Public Land Survey System. Four quadrants are formed by the intersection of a base line and a principal meridian. The letters $N$ or S locate the township north or south of the base line. The letters $E$ or W locate the range east or west of the principal meridian. The first numeral of the local site number specifies the hydrographic area as defined by Rush (1968). Nevada has been divided into 14 hydrographic regions or major basins and 256 individual hydrographic areas or valleys. The classification is used to compile information pertaining to water resources in Nevada. The second numeral indicates the township, the third the range, and the fourth the section in which the well is located. Letters following the section number locate the well within the section. The letters (A-D) are assigned within the section in a counter-clockwise direction beginning with " $A$ " in the northeast quarter of the section. Letters are assigned within each quarter section and successive subdivisions in the same manner. The first letter denotes the quarter section, the second the quarter-quarter section, the third the quarter-quarter-quarter section, and the fourth the quarter-quarter-quarter-quarter section. Where two or more wells are located within the smallest subdivision, consecutive numbers beginning with 1 are added to the letters in the order in which the wells are inventoried.

For example, well 105 N13 E19 25ABDD5 DLB10 is located in the SE $1 / 4$ of the SE $1 / 4$ of the NW $1 / 4$ of the NE $1 / 4$ of Section 25, T13N, R19E. It is located in hydrographic area 105 . It is the fifth inventoried well in that parcel. DLB10 is the local well name.

Prior to January 1976, local site numbers in Nevada were published according to the following general format: 19/28-36aabc1. The first number was the township north of the base line (if the township was south of the base line, the first number was followed by an "S"). The second number was the range east of the meridian, the third number was the section, and the following letter or letters and number indicated the quarter sections and sequence as defined above. 


\section{Abbreviations}

\begin{tabular}{ll} 
AFDM & ash free dry mass \\
Ar & argon \\
chl-a & chlorophyll a \\
CWSD & Carson Water Subconservancy District \\
DEET & N,N-Diethyl-m-toluamide \\
DO & dissolved oxygen \\
DOC & dissolved organic carbon \\
EFCR & East Fork Carson River \\
GPS & Global Positioning System \\
LRL & laboratory reporting level \\
LT-MDL & long-term method detection level \\
N & nitrogen \\
N & nitrogen gas \\
NAC & Nevada Administrative Code \\
NDEP & Nevada Division of Environmental Protection \\
NWIS & National Water Information System \\
NWOL & National Water Ouality Lab \\
O & oxygen \\
P & phosphorus \\
SC & specific conductance \\
SDT & East Fork Carson River near Muller Lane downstream transect \\
SMT & East Fork Carson River near Muller Lane middle-stream transect \\
SUT & East Fork Carson River near Muller Lane upstream transect \\
TDS & total dissolved solids \\
TKN & total Kjeldahl nitrogen \\
TN & total nitrogen \\
TP & total phosphorus \\
USGS & U.S. Geological Survey \\
VSMOW & Vienna-Standard Mean Ocean Water \\
\hline
\end{tabular}




\title{
Groundwater Contributions to Excessive Algal Growth in the East Fork Carson River, Carson Valley, West-Central Nevada, 2010 and 2012
}

\author{
By Nancy L. Alvarez, ${ }^{1}$ Randy A. Pahl, ${ }^{2}$ and Michael R. Rosen ${ }^{1}$
}

\section{Abstract}

Excessive algal growth and low dissolved oxygen concentrations were observed during low streamflow conditions during summer months along a 5,800-foot reach of the East Fork Carson River in Carson Valley, west-central Nevada. Algal growth from nutrient enrichment of a stream reduces aquatic diversity, threatens fish ecology and stream health, and can be a recreational nuisance. In response to concerns that groundwater discharging to the 5,800-foot reach of the East Fork Carson River may be a source of nutrients to the stream, the U.S. Geological Survey, in cooperation with the Carson Water Subconservancy District and the Nevada Division of Environmental Protection, conducted studies during the summers of 2010 and 2012 to gain an improved understanding of the contributions of nutrients to the stream from groundwater, characterize algal conditions and algal effects on water quality, assess potential sources of nitrate in groundwater discharging to the stream, and evaluate nitrate reduction in groundwater from denitrification.

A reconnaissance study in the summer of 2010 along the 5,800 -foot study reach located a subreach with clear evidence of nutrient-rich groundwater discharging to the stream. At the subreach, nitrate plus nitrite (referred to hereafter as nitrate) concentrations in groundwater discharging to the stream were high (average 2.75 milligrams per liter as nitrogen) along the right bank. The stream at this location had the highest stream nitrate concentrations (average 0.056 milligrams per liter as nitrogen) compared to other locations upstream and downstream of the subreach. As a result, the 2012 study focused on a 405-foot subreach of the East Fork Carson River centered where results from the 2010 study found the highest stream and groundwater concentrations of nitrate, as well as the greatest observed contributions of groundwater discharge to the stream.

Groundwater nutrient concentrations were much higher than stream nutrient concentrations during the summer of 2012 during low streamflow conditions at the 405 -foot subreach of the East Fork Carson River. Average groundwater nitrate and orthophosphate concentrations along the right bank of the 405-foot subreach were 9 and 12 times higher, respectively,

\footnotetext{
${ }^{1}$ U.S. Geological Survey.

${ }^{2}$ Nevada Division of Environmental Protection.
}

than in the stream at this subreach. Groundwater discharge rates to the study reach based on different methods varied from 0.09 to 1.2 cubic feet per second per mile. Estimated groundwater discharge rates to the right bank of the study subreach were used to calculate groundwater nutrient load estimates to the subreach right bank, which were found to be low when compared to stream nutrient loads.

Elevated algal biomass levels above nuisance thresholds were observed during the summers of 2010 and 2012. The study reach was characterized as mesotrophic-eutrophic during the 2010 study and eutrophic during the 2012 study. The presence of algae caused daily dissolved oxygen and $\mathrm{pH}$ fluctuations in the stream, resulting in exceedances of the State of Nevada water-quality standards owing to low dissolved oxygen concentrations and high $\mathrm{pH}$ concentrations, although the standards might not have been applicable during 2012 because of extremely low streamflow.

The addition of nutrients to the stream from the constant supply in groundwater discharge sustains the growth of algae during low streamflow conditions. In the summer when streamflow is low or very low, nutrient-rich groundwater discharge enters the stream through the sediment-water interface at the streambed. Because the attached algae is thick and stream velocity is low, the nutrient-rich water pools at the sediment-water interface. Higher nutrient concentrations at the streambed create a favorable microenvironment for algae attached to the substrate to consume available nutrients from the groundwater before the groundwater mixes with overlying stream water.

The source of nitrate in groundwater in this subreach is anthropogenic because nitrate concentrations are greater than background groundwater nitrate concentrations in Douglas County, high groundwater nitrate concentrations are only found at the right bank of the stream near a housing development, and organic wastewater compounds indicative of human-derived sources were also detected in groundwater wells on the right bank of the stream. Nitrogen and oxygen isotope concentrations of nitrate in shallow groundwater were used to determine the specific source of the nitrate, but the isotopic values indicated denitrification was occurring. Further investigation is needed to determine the specific anthropogenic source of the nitrate in the groundwater because the denitrification present in all samples obscures the original source of nitrogen. 


\section{Introduction}

During the summers of 2006 and 2007, Nevada Division of Environmental Protection (NDEP) performed qualitative algae screening surveys at a number of locations in the Carson River. Algal biomass covered 100 percent of the streambed along a 5,800-foot reach of the lower East Fork of the Carson River (EFCR) between Highway 88 and Muller Lane during both the 2006 and 2007 algae surveys (Pahl, 2007a; fig. 1). Low dissolved oxygen concentrations were measured in this reach (less than 5 milligrams per liter, $\mathrm{mg} / \mathrm{L}$ ) during the summers of 2001 and 2005 (Pahl, 2002, 2006b, 2007a). Stream reaches with excessive algal growth typically are a concern because this condition may reduce aquatic diversity, threaten fish ecology, create large diurnal dissolved oxygen (DO) fluctuations, and be a nuisance to recreational uses such as boating and fishing.

Past studies by the NDEP and others have characterized factors in the Carson River that are associated with excessive algal growth, including stream nutrient concentrations, water temperature, shading over the stream, channel substrate, and DO concentrations (Pahl, 2002, 2006a, 2006b, 2006c, 2007a, 2007b, 2008; Fritsen and others, 2006; Watershed Sciences, Inc., 2006). High stream nitrate and orthophosphate concentrations may promote eutrophic conditions that lead to excessive growth of algae. Maurer and others (2009, p. 97) compiled nitrate data for sites along the Carson River and found the highest nitrate concentration in a sample collected from EFCR at Highway 88, site CV88 (fig. 1; total nitrate plus nitrite of $1.76 \mathrm{mg} / \mathrm{L}$ as nitrogen, N), upstream of the 5,800-foot reach observed by NDEP to have excessive algal growth.

Nutrients in groundwater discharging to a stream can be an important contributor to excessive algal growth and biomass production (Cox and others, 2005), particularly during low streamflow conditions. An airborne thermal infrared survey in summer 2006 (Watershed Sciences, Inc., 2006; Pahl, 2008) provides evidence for groundwater discharge to the EFCR in the area of excessive algal growth (fig. 2). Using this dataset, four seeps within the EFCR alluvial channel between Highway 88 and Muller Lane were identified. Colder water associated with the seeps indicate areas of groundwater discharge to the EFCR (Watershed Sciences, Inc., 2006; Pahl, 2008) and, in areas of agricultural or urban land use, a potential source of nutrients to the stream. Naranjo and others (2013) published groundwater nutrient data for wells in Carson Valley, and in four that surrounded the study reach, groundwater nitrate concentrations ranged from 0.4 to $1.8 \mathrm{mg} / \mathrm{L}$ as $\mathrm{N}$.

\section{Purpose and Scope}

Based on the algal screening surveys and findings by Pahl (2007a) and water-quality data from the U.S. Geological Survey (USGS), NDEP and the Carson Water Subconservancy District (CWSD) recommended in 2009 that additional study is warranted along the EFCR in the area of excessive algal growth. Of principal concern to NDEP and CWSD is to (1) better characterize algal conditions, including a more quantitative assessment of algal biomass, and (2) gain an improved understanding of the contribution of nutrients to the EFCR from groundwater during low streamflow conditions.

The USGS, CWSD, and NDEP began a cooperative study in 2010 to characterize algal conditions in a selected reach of the EFCR and investigate the influence of groundwater discharge on the excessive algal growth. The main objectives of the study were the following:

- characterize (1) algal biomass and trophic levels in areas of algal growth and (2) algal effects on water quality,

- identify areas of groundwater discharge to the EFCR within and adjacent to reaches of high algal growth,

- determine nutrient concentrations and loads in select reaches of the EFCR study area and adjacent groundwater areas,

- evaluate nitrate reduction owing to denitrification within and adjacent to areas of groundwater discharge to the EFCR study area, and

- identify potential sources of nitrate in groundwater discharging to the EFCR study area.

This report summarizes the results of two data-collection efforts completed in the summers of 2010 and 2012 during low streamflow conditions in the EFCR. The 2010 study was an initial reconnaissance-level effort to investigate potential contributing factors to eutrophic conditions and excessive algal growth and to identify a stream reach on the EFCR for a more detailed and focused investigation. Using the results of the 2010 reconnaissance study, a smaller subreach of the EFCR was identified for additional biologic, hydrologic, and water-quality data collection in the summer of 2012. Both datasets were evaluated to characterize algal conditions and assess groundwater contributions to excessive algal growth in the EFCR. Results of this study are intended to assist water managers in understanding conditions and processes contributing to excessive algal growth. A better understanding of the conditions and processes leading to high algal growth will aid in developing strategies to mitigate excessive algal growth along this reach of the EFCR as well as in other streams in Nevada. 


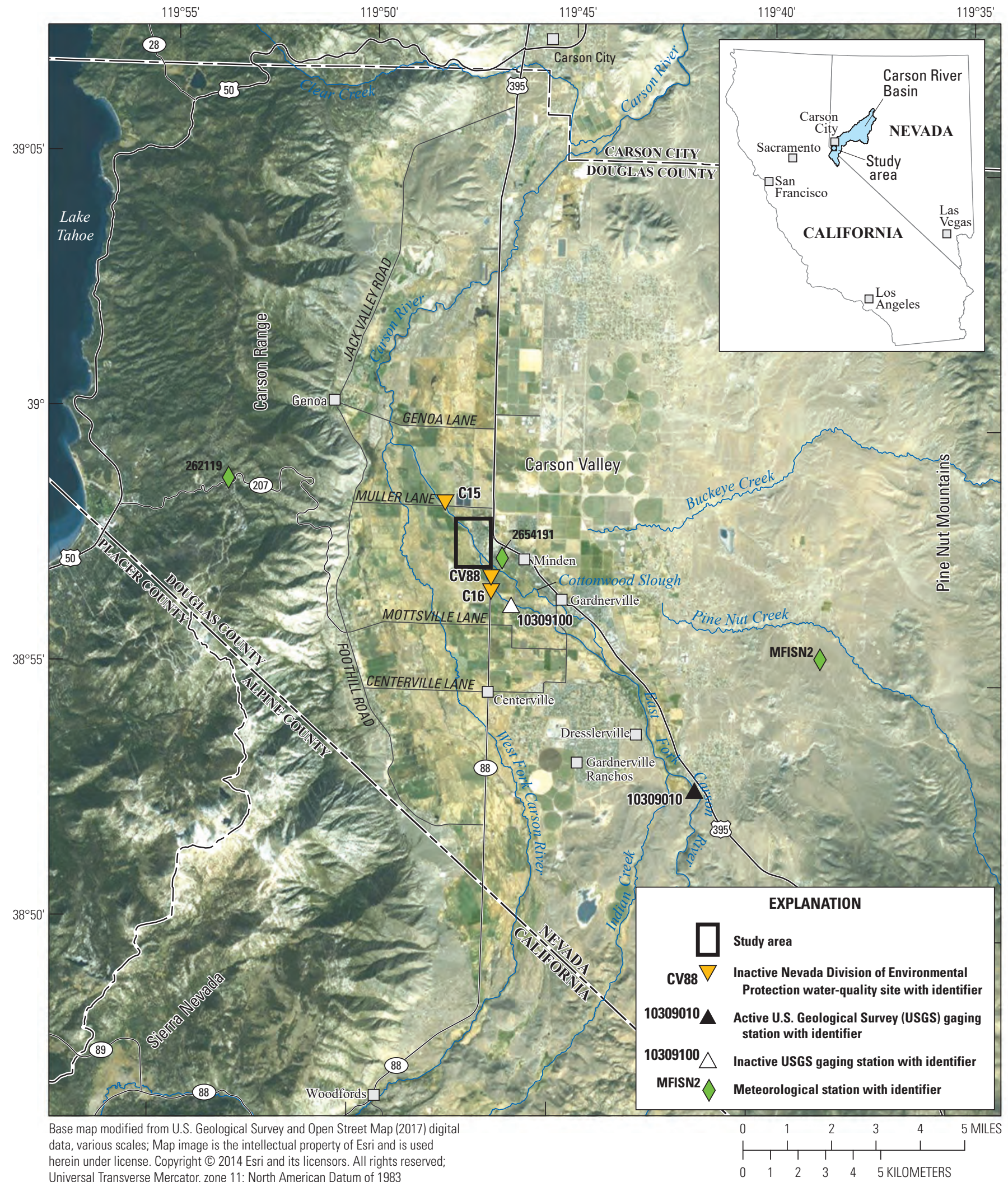

Figure 1. Location of study area on the East Fork Carson River, Carson Valley, west-central Nevada. 


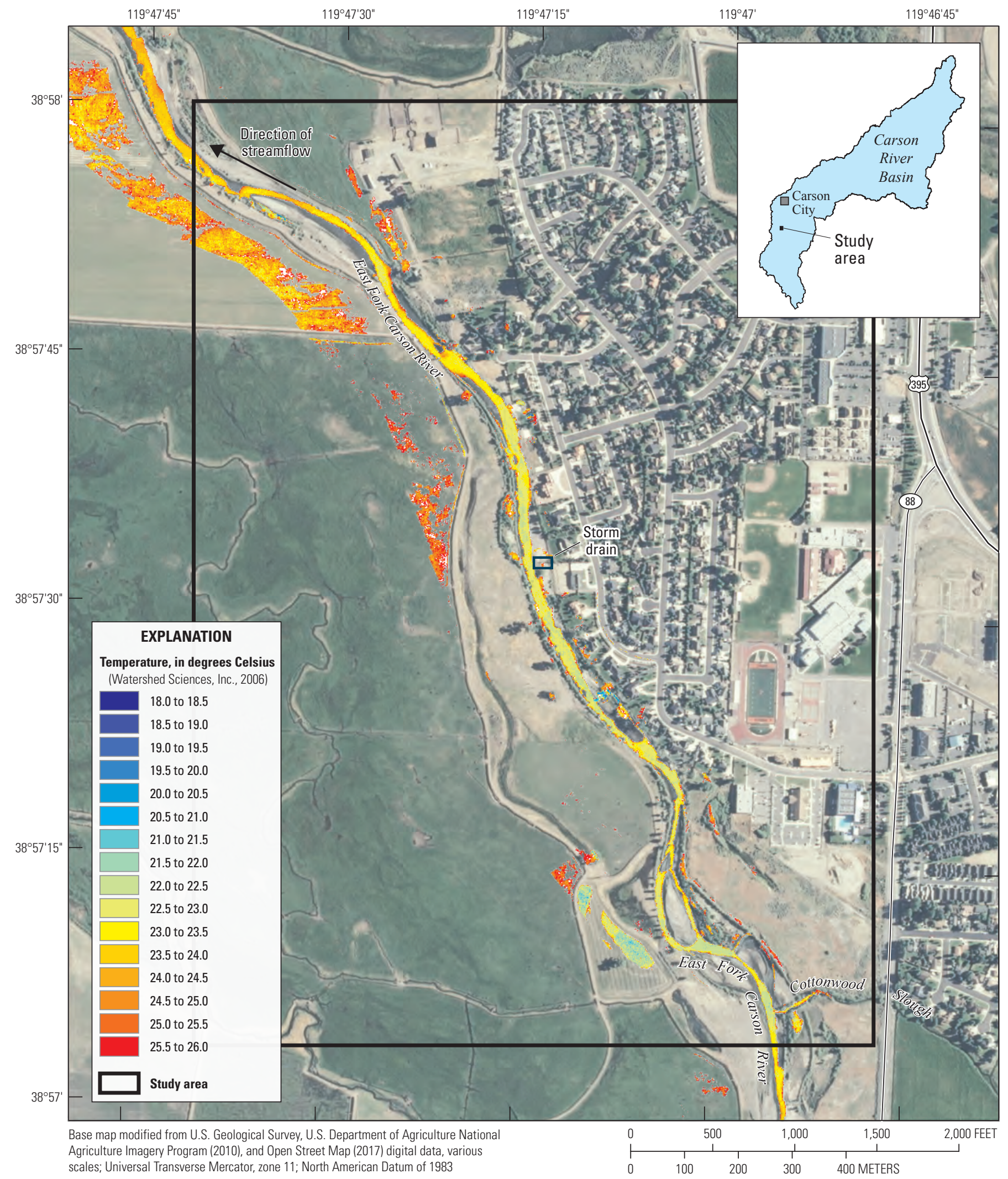

Figure 2. Stream temperature data for the East Fork Carson River, mid-afternoon on August 8, 2006, Carson Valley, west-central Nevada. 


\section{Environmental Setting}

The hydrology of Carson Valley is dominated by the Carson River. The EFCR originates on the eastern slopes of the Sierra Nevada in California south of the study area and combines with the West Fork Carson River near the town of Genoa, Nevada (fig. 1). The Carson River continues to flow northward and exits the Carson Valley southeast of Carson City, Nev. (fig. 1). Snowmelt runoff from the upper watersheds and tributary streamflow from the Carson Range to the west are the primary sources of water to Carson Valley. Streamflow from the Carson River is diverted for irrigation of agricultural lands through a complex system of unlined ditches and canals throughout the valley. The water table is shallow under much of the valley floor owing, in part, to infiltration of applied irrigation water (Berger and Medina, 1999; Maurer and others, 2004). A more detailed description of the hydrology of Carson Valley, including discussion of primary water budget components, can be found in Maurer and others (2004), Maurer and others (2006), Maurer and Berger (2006), and Yager and others (2012).

Excessive algal growth in the EFCR along a reach between Highway 88 and Muller Lane was inventoried by NDEP (Pahl, 2007a) in 2006 and 2007 (fig. 1). Nutrient inputs to this reach that may affect algal growth could occur from land use immediately adjacent to the EFCR, which is residential along the right bank and agricultural on the left bank (fig. 2). State of Nevada groundwater discharge permits have not been issued for use of treated wastewater effluent for irrigation immediately upstream or upgradient of potential groundwater discharge to the stream. However, some land west of the EFCR near the downstream section of this reach is irrigated with treated wastewater effluent (Alvarez and Seiler, 2004, p. 26). Although treated wastewater effluent is used for irrigation in California at the upstream end of Carson Valley within the drainage of the West Fork Carson River, any return flows from this irrigation would not enter the EFCR (Alvarez and Seiler, 2004, p. 26). Nutrient inputs to this reach of EFCR also could occur from upstream tributary inflow from Cottonwood Slough (fig. 2), which receives urban runoff from Minden and Gardnerville, Nev., and irrigation return flow from adjacent land use (Alvarez and Seiler, 2004, p. 30). Additionally, nutrient inputs to this reach could occur from drains receiving storm or snowmelt runoff. For example, one storm drain for the adjacent housing development connects to the EFCR within this reach (figs. 2 and 3); however, the drain is dry during the summer except during large storm events.

Typical monthly streamflow conditions at the study reach are shown in figure 4 . Streamflow discharge data are available for water years 1975-84 and 1995-98 at a discontinued USGS stream gaging station, "East Fork Carson River at Minden" (station number 10309100), located just upstream

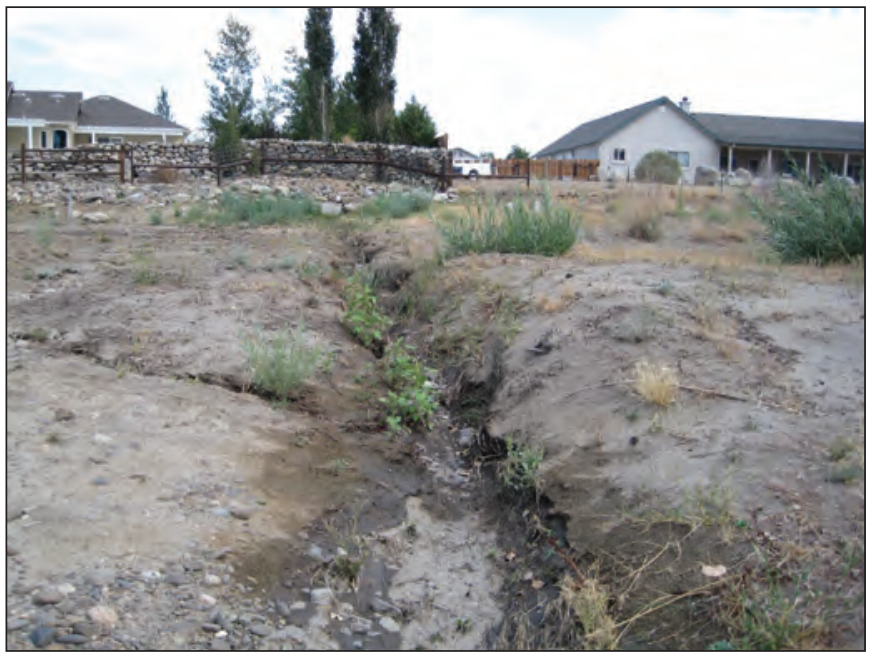

Figure 3. Small drainage channel formed by storm or snowmelt runoff discharging from a storm drain that connects to the stream site East Fork Carson River near Muller Lane middle-stream transect (SMT), Carson Valley, west-central Nevada. Photograph taken on August 17, 2012, after a storm event.

from the reach with excessive algae growth (fig. 1). Current USGS stream gaging stations on the EFCR are much farther upstream of the study reach and do not represent hydrologic conditions at the study reach because of diversions located between the stream gaging stations and the study reach. The largest mean monthly discharge occurs in May, whereas the lowest mean monthly discharge occurs in September (fig. 4). Mean monthly discharges for July, August, September, and October at the discontinued stream gaging station closest to the study reach are $354,39,12$, and 30 cubic feet per second $\left(\mathrm{ft}^{3} / \mathrm{s}\right)$, respectively.

The interaction between streamflow and shallow groundwater in the Carson Valley results in a complex pattern of groundwater and surface-water exchange (Yager and others, 2012). The relative altitude of the stream stage and groundwater level determines if the stream is gaining from groundwater inflow (discharge) or losing streamflow to the shallow aquifer (Winter and others, 1998). Yager and others (2012) suggested that the direction of the hydraulic gradients in Carson Valley between the stream and water table can change between wet and dry years and within a given irrigation season because the operation of diversions can change the stream stage throughout the season. In gaining stream reaches, mixing of shallow groundwater and surface water can take place in the hyporheic zone. Stream water enters this zone and eventually reenters the stream further downstream. Hyporheic exchange increases the residence time of water within a stream system and has a strong influence on biogeochemical processes such as denitrification. 


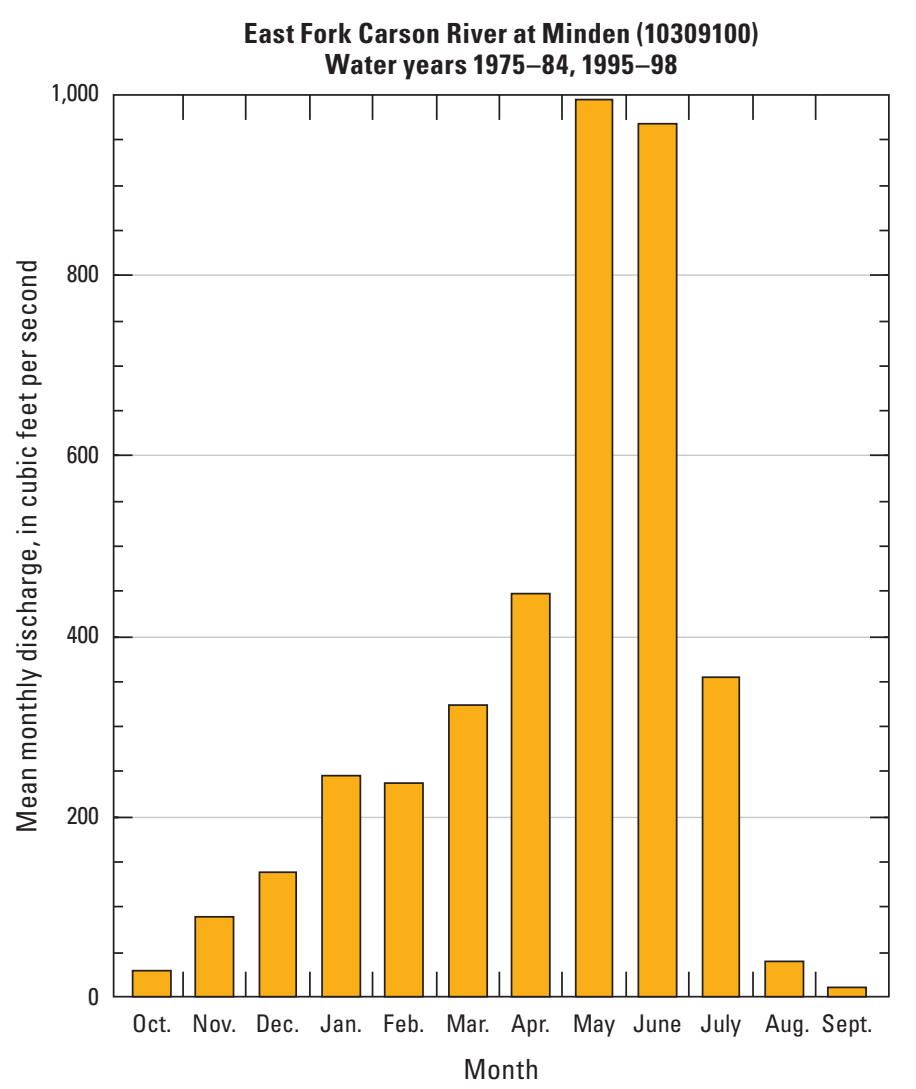

Figure 4. Mean monthly discharge for water years 1975-84 and 1995-98 at East Fork Carson River at Minden (U.S. Geological Survey stream gaging station 10309100), Carson Valley, westcentral Nevada.

\section{Study Design and Collection of Basic Data}

To characterize and assess the influence of groundwater on excessive algal growth in the EFCR, surface-water and groundwater data were collected from multiple study transects within and adjacent to a 5,800-foot reach identified by NDEP. The study was designed using two data-collection efforts, an initial reconnaissance effort covering the NDEP 5,800-foot reach in the summer of 2010, and a more focused investigative effort within this reach in the summer of 2012. Data collected in 2010 were evaluated to identify a reach of the stream with excessive algae that may be associated with discharge of nutrient-rich groundwater to the stream. Data collected in 2012 were used to identify and characterize the hydrologic and water-quality factors that may be contributing to the excessive algal production.

Groundwater and stream data were collected along the 5,800-foot reach of EFCR between Highway 88 and Muller Lane during the summer of 2010 (fig. 5), referred to in this report as the "study reach." Within the study reach, 10 shallow drive-point observation wells were installed along 3 groundwater well transects labeled well transect
1 (upstream), well transect 2 (middle-stream), and well transect 3 (downstream; table 1). Co-located at well transect 1 (upstream), well transect 2 (middle-stream), and well transect 3 (downstream) was a stream site labeled SUT, SMT, and SDT, respectively (table 1). The shallow observation wells were installed at the edge of or in the middle of the stream to determine the groundwater hydraulic gradient to or from the stream. The wells were also used to determine the concentration of dissolved nitrate plus nitrite (hereafter referred to as nitrate), dissolved orthophosphate (hereafter referred to as orthophosphate), and other nutrients in groundwater either going toward or coming from the stream. Well transect 1 (upstream) and well transect 3 (downstream) were located about 2,900 and 2,870 feet (ft) from well transect 2 (middle-stream), respectively (table 2; fig. 5). The 10 shallow observation wells installed in 2010 (and removed in 2011) included the following:

- well transect 1 (upstream)

- 1-well, left bank (ULB7)

- 1-well, middle of the stream (UMS8)

- 1-well, right bank (URB9)

- well transect 2 (middle-stream)

- 1-well, left bank (MLB4)

- 1-well, middle of the stream (MMS5)

- 1-well, right bank (MRB6)

- well transect 3 (downstream)

- 2-wells, left bank (DLB10 and DLB1)

- 1-well, middle of the stream (DMS2)

- 1-well, right bank (DRB3)

During the summer of 2012, groundwater data collection was focused along a smaller subreach near the 2010 well transect 2 (middle-stream), referred to in this report as the "study subreach." Three groundwater well transects were added, one at the same location as well transect 2 (middlestream) in 2010, one located upstream, and one located downstream to investigate the 400-ft study subreach (fig. 6). The 2012 upstream well transect, well transect 4 (upper), was located about $210 \mathrm{ft}$ upstream from well transect 2 (middlestream), and the 2012 downstream well transect, well transect 5 (lower), was located about $190 \mathrm{ft}$ downstream from well transect 2 (middle-stream; table 2). Similar to the observation wells installed in 2010, 13 shallow drive-point observation wells were installed in 2012 at well transect 4 (upper), well transect 2 (middle-stream), and well transect 5 (lower). All 2012 observation wells were installed along transects perpendicular to the stream to estimate hydraulic gradients to or from the stream, groundwater discharge to the stream, and associated nutrient concentrations and loads (fig. 6; table 1). 


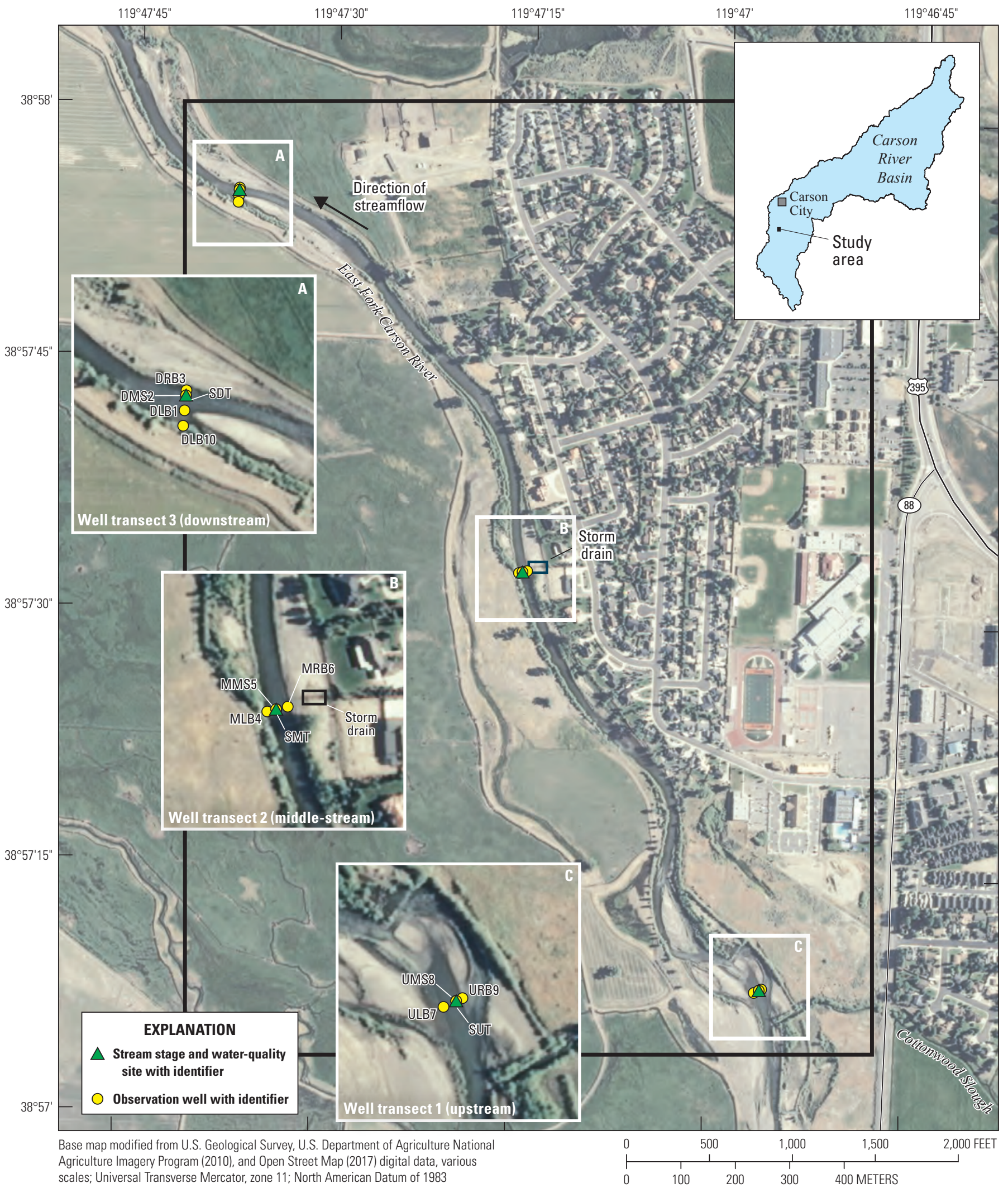

Figure 5. Location of data collection sites including three well transects and three stream sites, as part of a reconnaissance study (2010) along the study reach of the East Fork Carson River, Carson Valley, west-central Nevada. Stream sites are East Fork Carson River near Muller Lane upstream transect (SUT), East Fork Carson River near Muller Lane middle-stream transect (SMT), and East Fork Carson River near Muller Lane downstream transect (SDT). 
Table 1. Description of stream sites, observation wells, and types of data collected in 2010 and 2012, East Fork Carson River, Carson Valley, west-central Nevada.

[Site locations are shown in figures 5 and 6. Latitude and longitude locations are degrees, minutes, seconds and are referenced to North American Datum of 1983 (NAD 83 ); altitudes are in reference to North American Vertical Datum of 1988 (NAVD 88). Abbreviations: ft, foot; in., inch; - , not applicable]

\begin{tabular}{|c|c|c|c|c|c|c|c|c|c|c|}
\hline $\begin{array}{c}\text { USGS site } \\
\text { identification } \\
\text { number }\end{array}$ & Site name & $\begin{array}{l}\text { Site short } \\
\text { name }\end{array}$ & Latitude & Longitude & $\begin{array}{l}\text { Altitude } \\
\text { of land } \\
\text { surface } \\
\text { (ft above } \\
\text { NAVD 88) }\end{array}$ & $\begin{array}{c}\text { Altitude of } \\
\text { reference } \\
\text { datum } \\
\text { (ft above } \\
\text { NAVD 88) }\end{array}$ & $\begin{array}{l}\text { Well depth, } \\
\text { in feet below } \\
\text { land surface }\end{array}$ & $\begin{array}{l}\text { Well } \\
\text { diameter } \\
\text { (in.) }\end{array}$ & $\begin{array}{c}\text { Well } \\
\text { screened } \\
\text { interval } \\
\text { (ft below } \\
\text { land surface) }\end{array}$ & $\begin{array}{l}\text { Types } \\
\text { of data }{ }^{1}\end{array}$ \\
\hline \multicolumn{11}{|c|}{ Stream sites 2010} \\
\hline 385708119465604 & $\begin{array}{l}\text { East Fork Carson River near } \\
\text { Muller Lane upstream transect }\end{array}$ & SUT & 385708.20 & 1194655.60 & - & 4,698 & - & - & - & Q, WL, N \\
\hline 385733119471504 & $\begin{array}{l}\text { East Fork Carson River near } \\
\text { Muller Lane middle-stream } \\
\text { transect }\end{array}$ & SMT & 385732.70 & 1194714.59 & - & 4,688 & - & - & - & $\mathrm{Q}, \mathrm{WL}, \mathrm{N}$ \\
\hline 385755119473704 & $\begin{array}{l}\text { East Fork Carson River near } \\
\text { Muller Lane downstream } \\
\text { transect }\end{array}$ & SDT & 385754.97 & 1194737.06 & - & 4,684 & - & - & - & $\begin{array}{l}\text { Q, WL, N, } \\
\text { CWQ }\end{array}$ \\
\hline \multicolumn{11}{|c|}{ Stream sites 2012} \\
\hline 385708119465604 & $\begin{array}{l}\text { East Fork Carson River near } \\
\text { Muller Lane upstream transect }\end{array}$ & SUT & 385708.20 & 1194655.60 & - & 4,698 & - & - & - & Q, N \\
\hline 385733119471504 & $\begin{array}{l}\text { East Fork Carson River near } \\
\text { Muller Lane middle-stream } \\
\text { transect }\end{array}$ & SMT & 385732.70 & 1194714.59 & - & 4,688 & - & - & - & $\begin{array}{l}\text { Q, WL, N, } \\
\text { DOC, } \\
\text { CWL }\end{array}$ \\
\hline 385755119473704 & $\begin{array}{l}\text { East Fork Carson River near } \\
\text { Muller Lane downstream } \\
\text { transect }\end{array}$ & SDT & 385754.97 & 1194737.06 & - & 4,684 & - & - & - & Q, N, CWQ \\
\hline \multicolumn{11}{|c|}{ Groundwater sites 2010} \\
\hline \multicolumn{11}{|c|}{ Well transect 1 (upstream) } \\
\hline 385708119465601 & 105 N13 E20 31BABD1 ULB7 & ULB7 & 385708.05 & 1194655.98 & - & 4,698 & 3.9 & 1.6 & $2.0-3.1$ & $\mathrm{WL}, \mathrm{N}$ \\
\hline 385708119465602 & 105 N13 E20 31BABD2 UMS8 & UMS8 & 385708.20 & 1194655.60 & - & 4,698 & 3.9 & 1.6 & $2.0-3.1$ & WL, $N$ \\
\hline 385708119465603 & 105 N13 E20 31BABD3 URB9 & URB9 & 385708.27 & 1194655.41 & - & 4,698 & 3.9 & 1.6 & $2.0-3.1$ & $\mathrm{WL}, \mathrm{N}$ \\
\hline \multicolumn{11}{|c|}{ Well transect 2 (middle-stream) } \\
\hline 385733119471501 & 105 N13 E20 30CBCB1 MLB4 & MLB4 & 385732.64 & 1194714.86 & - & 4,688 & 3.9 & 1.6 & $2.0-3.1$ & WL, N, 24 \\
\hline 385733119471502 & 105 N13 E20 30CBCB2 MMS5 & MMS5 & 385732.70 & 1194714.58 & - & 4,688 & 3.9 & 1.6 & $2.0-3.1$ & WL, N, 24 \\
\hline 385733119471503 & 105 N13 E20 30CBCB3 MRB6 & MRB6 & 385732.77 & 1194714.24 & - & 4,688 & 3.9 & 1.6 & $2.0-3.1$ & WL, N, 24 \\
\hline
\end{tabular}


Table 1. Description of stream sites, observation wells, and types of data collected in 2010 and 2012, East Fork Carson River, Carson Valley, west-central Nevada.-Continued

[Site locations are shown in figures 5 and 6. Latitude and longitude locations are degrees, minutes, seconds and are referenced to North American Datum of 1983 (NAD 83); altitudes are in reference to North American Vertical Datum of 1988 (NAVD 88). Abbreviations: ft, foot; in., inch; - , not applicable]

\begin{tabular}{|c|c|c|c|c|c|c|c|c|c|c|}
\hline $\begin{array}{c}\text { USGS site } \\
\text { identification } \\
\text { number }\end{array}$ & Site name & $\begin{array}{l}\text { Site short } \\
\text { name }\end{array}$ & Latitude & Longitude & $\begin{array}{c}\text { Altitude } \\
\text { of land } \\
\text { surface } \\
\text { (ft above } \\
\text { NAVD 88) }\end{array}$ & $\begin{array}{c}\text { Altitude of } \\
\text { reference } \\
\text { datum } \\
\text { (ft above } \\
\text { NAVD 88) }\end{array}$ & $\begin{array}{l}\text { Well depth, } \\
\text { in feet below } \\
\text { land surface }\end{array}$ & $\begin{array}{c}\text { Well } \\
\text { diameter } \\
\text { (in.) }\end{array}$ & $\begin{array}{c}\text { Well } \\
\text { screened } \\
\text { interval } \\
\text { (ft below } \\
\text { land surface) }\end{array}$ & $\begin{array}{l}\text { Types } \\
\text { of data }{ }^{1}\end{array}$ \\
\hline \multicolumn{11}{|c|}{ Groundwater sites 2010 -Continued } \\
\hline \multicolumn{11}{|c|}{ Well transect 3 (downstream) } \\
\hline 385755119473705 & 105 N13 E19 25ABDD5 DLB10 & DLB10 & 385754.24 & 1194737.12 & - & 4,684 & 3.9 & 1.6 & $2.0-3.1$ & $\mathrm{WL}, \mathrm{N}$ \\
\hline 385755119473701 & 105 N13 E19 25ABDD1 DLB1 & DLB1 & 385754.61 & 1194737.09 & - & 4,684 & 3.9 & 1.6 & $2.0-3.1$ & WL, $\mathrm{N}$ \\
\hline 385755119473702 & 105 N13 E19 25ABDD2 DMS2 & DMS2 & 385754.97 & 1194737.06 & - & 4,684 & 3.9 & 1.6 & $2.0-3.1$ & WL, $N$ \\
\hline 385755119473703 & 105 N13 E19 25ABDD3 DRB3 & DRB3 & 385755.09 & 1194737.05 & - & 4,684 & 3.9 & 1.6 & $2.0-3.1$ & $\mathrm{WL}, \mathrm{N}$ \\
\hline \multicolumn{11}{|c|}{ Groundwater sites 2012} \\
\hline \multicolumn{11}{|c|}{ Well transect 4 (upper) } \\
\hline 385731119471401 & 105 N13 E20 30CBCA1 ULB2 & ULB2 & 385730.84 & 1194714.09 & $4,688.05$ & - & 3.6 & 1.63 & $2.0-3.2$ & $\begin{array}{l}\text { WL, N, } \\
\text { DOC, DG }\end{array}$ \\
\hline 385731119471402 & 105 N13 E20 30CBCA2 UMS3 & UMS3 & 385730.95 & 1194713.77 & $4,688.54$ & - & 3.6 & 1.63 & $2.0-3.2$ & $\begin{array}{l}\text { WL, N, } \\
\text { DOC, I, } \\
\text { DG }\end{array}$ \\
\hline 385731119471403 & 105 N13 E20 30CBCA3 URB4 & URB4 & 385731.05 & 1194713.45 & $4,688.73$ & - & 3.6 & 1.63 & $2.0-3.2$ & $\begin{array}{l}\text { WL, N, } \\
\text { DOC, I, } \\
\text { DG }\end{array}$ \\
\hline 385731119471404 & 105 N13 E20 30CBCA4 URBFS5 & URBFS5 & 385731.31 & 1194712.70 & $4,694.04$ & - & 6.9 & 1.63 & $5.3-6.5$ & $\begin{array}{l}\text { WL, CWL, } \\
\text { N, DOC, I, } \\
\text { DG, OWC }\end{array}$ \\
\hline \multicolumn{11}{|c|}{ Well transect 2 (middle-stream) } \\
\hline 385733119471505 & 105 N13 E20 30CBCA6 MLB7 & MLB7 & 385732.91 & 1194714.96 & $4,688.71$ & - & 3.5 & 1.63 & $2.0-3.2$ & WL, N, DG \\
\hline 385733119471506 & 105 N13 E20 30CBCA7 MMS8 & MMS8 & 385732.97 & 1194714.68 & $4,688.10$ & - & 3.6 & 1.63 & $2.0-3.2$ & WL, N, DG \\
\hline 385733119471507 & 105 N13 E20 30CBCA8 MRB9 & MRB9 & 385733.03 & 1194714.36 & $4,688.88$ & - & 3.5 & 1.63 & $2.0-3.2$ & $\begin{array}{r}\text { WL, CWL, } \\
\text { N, I, DG }\end{array}$ \\
\hline 385733119471508 & $\begin{array}{l}105 \text { N13 E20 30CBCA9 } \\
\text { MRBMFS10 }\end{array}$ & MRBMFS10 & 385733.11 & 1194713.98 & $4,691.62$ & - & 4.9 & 1.63 & $3.4-4.6$ & $\begin{array}{l}\text { WL, CWL, } \\
\text { N, DOC, I, } \\
\text { DG, OWC }\end{array}$ \\
\hline 385733119471510 & $\begin{array}{l}105 \text { N13 E20 30CBCA11 } \\
\text { MRBFFS12 }\end{array}$ & MRBFFS12 & 385733.29 & 1194713.09 & $4,694.03$ & - & 7.1 & 1.63 & $5.6-6.8$ & $\begin{array}{l}\text { WL, CWL, } \\
\text { N, DOC, } \\
\text { DG, OWC }\end{array}$ \\
\hline
\end{tabular}


Table 1. Description of stream sites, observation wells, and types of data collected in 2010 and 2012, East Fork Carson River, Carson Valley, west-central Nevada.-Continued

[Site locations are shown in figures 5 and 6. Latitude and longitude locations are degrees, minutes, seconds and are referenced to North American Datum of 1983 (NAD 83 ); altitudes are in reference to North American Vertical Datum of 1988 (NAVD 88). Abbreviations: ft, foot; in., inch; - , not applicable]

\begin{tabular}{|c|c|c|c|c|c|c|c|c|c|c|}
\hline $\begin{array}{c}\text { USGS site } \\
\text { identification } \\
\text { number }\end{array}$ & Site name & $\begin{array}{l}\text { Site short } \\
\text { name }\end{array}$ & Latitude & Longitude & $\begin{array}{c}\text { Altitude } \\
\text { of land } \\
\text { surface } \\
\text { (ft above } \\
\text { NAVD 88) }\end{array}$ & $\begin{array}{c}\text { Altitude of } \\
\text { reference } \\
\text { datum } \\
\text { (ft above } \\
\text { NAVD 88) }\end{array}$ & $\begin{array}{l}\text { Well depth, } \\
\text { in feet below } \\
\text { land surface }\end{array}$ & $\begin{array}{l}\text { Well } \\
\text { diameter } \\
\text { (in.) }\end{array}$ & $\begin{array}{c}\text { Well } \\
\text { screened } \\
\text { interval } \\
\text { (ft below } \\
\text { land surface) }\end{array}$ & $\begin{array}{l}\text { Types } \\
\text { of data }{ }^{1}\end{array}$ \\
\hline \multicolumn{11}{|c|}{ Groundwater sites 2012-Continued } \\
\hline \multicolumn{11}{|c|}{ Well transect 5 (lower) } \\
\hline 385735119471501 & 105 N13 E20 30CBBC1 DLB14 & DLB14 & 385734.82 & 1194715.44 & $4,688.28$ & - & 3.6 & 1.63 & $2.0-3.2$ & WL, N, DOC \\
\hline 385735119471502 & 105 N13 E20 30CBBC2 DMS15 & DMS15 & 385734.87 & 1194715.03 & $4,687.57$ & - & 3.6 & 1.63 & $2.0-3.2$ & WL, N, I, DG \\
\hline 385735119471503 & 105 N13 E20 30CBBC3 DRB16 & DRB16 & 385734.90 & 1194714.80 & $4,688.02$ & - & 3.6 & 1.63 & $2.0-3.2$ & WL, N, I, DG \\
\hline 385735119471506 & $\begin{array}{l}105 \text { N13 E20 30CBBC5 } \\
\text { DRBFS20 }\end{array}$ & DRBFS20 & 385735.05 & 1194713.83 & $4,693.72$ & - & 7.2 & 1.63 & $5.7-6.9$ & $\begin{array}{l}\text { WL, CWL, } \\
\text { N, DOC, I, } \\
\text { DG, OWC }\end{array}$ \\
\hline
\end{tabular}

24, 24 hours of nutrient and chloride concentrations collected every 2 hours; CWL, continuous water level; CWQ, continuous dissolved oxygen, pH, temperature, and specific conductance concentrations; DG, dissolved gas concentrations; DOC, dissolved organic carbon concentrations; I, nitrogen and oxygen isotopes concentrations; N, nutrients and chloride concentrations; OWC, organic wastewater compound concentrations; Q, instantaneous discharge measurements; WL, discrete water-level measurements. 
Table 2. Distances between stream and groundwater sites in study reach, 2010 and 2012, East Fork Carson River, Carson Valley, west-central Nevada.

[Site locations are shown in figures 5 and 6. Site descriptions are available in table 1. Abbreviation: ft, foot; SDT, East Fork Carson River near Muller Lane downstream transect; SMT, East Fork Carson River near Muller Lane middle-stream transect; SUT, East Fork Carson River near Muller Lane upstream transect]

\begin{tabular}{|c|c|}
\hline Site pair & $\begin{array}{c}\text { Distance } \\
\text { between } \\
\text { (ft) }\end{array}$ \\
\hline \multicolumn{2}{|l|}{2010} \\
\hline SUT-SMT & 2,897 \\
\hline SMT-SDT & 2,868 \\
\hline $\begin{array}{l}\text { Well transect } 1 \text { (upstream) - well transect } 2 \\
\text { (middle-stream) }\end{array}$ & 2,897 \\
\hline $\begin{array}{l}\text { Well transect } 2 \text { (middle-stream) - well transect } 3 \\
\quad(\text { downstream) }\end{array}$ & 2,868 \\
\hline \multicolumn{2}{|l|}{2012} \\
\hline $\begin{array}{l}\text { Well transect } 4 \text { (upper) — well transect } 2 \\
\quad \text { (middle-stream) }\end{array}$ & 213 \\
\hline $\begin{array}{l}\text { Well transect } 2 \text { (middle-stream)—-well transect } 5 \\
\text { (lower) }\end{array}$ & 192 \\
\hline URB4-URBFS5 & 65 \\
\hline MRB9-MRBFFS12 & 104 \\
\hline DRB16-DRBFS20 & 78 \\
\hline URB4-MRB9 & 213 \\
\hline MRB9-DRB16 & 192 \\
\hline URBFS5-MRBFFS 12 & 203 \\
\hline MRBFFS12-DRBFS20 & 187 \\
\hline SUT-SMT & 2,897 \\
\hline SMT-SDT & 2,868 \\
\hline
\end{tabular}

The 13 shallow observation wells installed in 2012 included the following:

- well transect 4 (upper)

- 1-well, left bank (ULB2)

- 1-well, middle of the stream (UMS3)

- 2-wells, right bank (URB4 and URBFS5)

- well transect 2 (middle-stream)

- 1-well, left bank (MLB7)

- 1-well, middle of the stream (MMS8)

- 3-wells, right bank (MRB9, MRBMFS10, and MRBFFS12)

- well transect 5 (lower)

- 1-well, left bank (DLB14)

- 1-well, middle of the stream (DMS15)

- 2-wells, right bank (DRB16, and DRBFS20)

High-precision Global Positioning System (GPS) equipment was used to determine the location of all observation wells and the altitude of established (1) measuring points for water-level measurements in 2010 and (2) reference datum in 2012. High precision laser levels with accuracy of plus or minus $0.004 \mathrm{ft}$ were used in 2012 to determine altitude of measuring points for water-level measurements relative to the reference datum.

Observation wells installed across the EFCR in the summers of 2010 and 2012 established multiple transects for the collection of basic hydrologic data (table 3). Groundwater-level and stream-stage measurements were collected in 2010 and 2012 to determine hydraulic gradients. Periodic groundwater-level and stream-stage measurements were made at all wells and stream sites, respectively, and these measurements were supplemented by a more intense data-collection effort of continuous groundwater-level and stream-stage measurements over a 2-month period from September 15-November 29, 2012. Additionally, continuous (every 15 minutes) groundwater and stream temperature data collected in 2010 and instantaneous stream discharge measurements in 2010 and 2012 were combined with groundwater-level and stream-stage datasets to determine groundwater inflow (or discharge) to the stream (gaining stream) or streamflow loss from the stream (losing stream). All groundwater-level, stream-stage, stream discharge, and groundwater temperature measurements were collected using established USGS protocols (table 3), and data were archived in the USGS National Water Information System (NWIS) database (https://waterdata.usgs.gov/nv/nwis/nwis). 


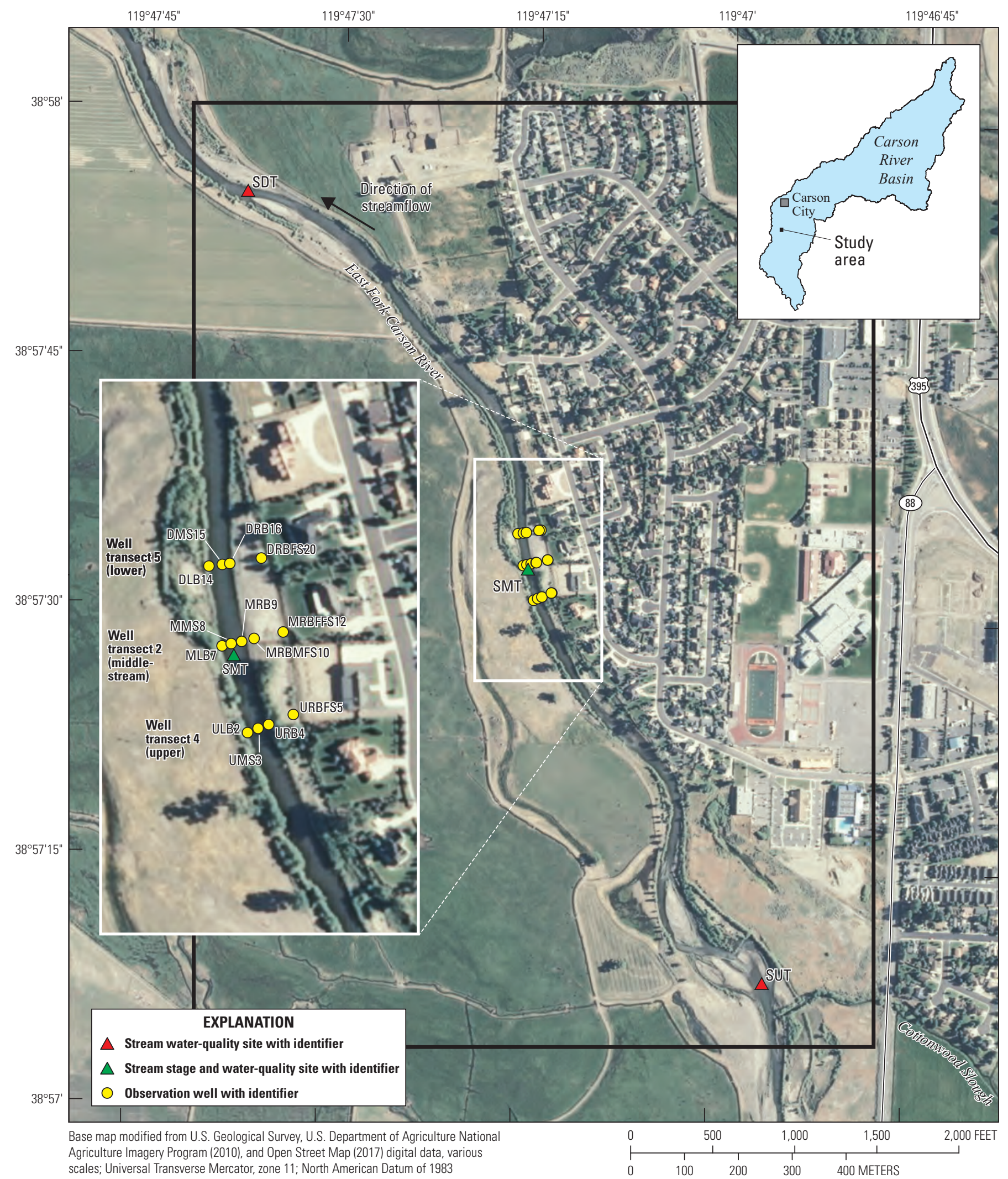

Figure 6. Location of data collection sites including three well transects and three stream sites, as part of the investigative study (2012) along the study reach and subreach of the East Fork Carson River, Carson Valley, west-central Nevada. Stream sites are East Fork Carson River near Muller Lane upstream transect (SUT), East Fork Carson River near Muller Lane middle-stream transect (SMT), and East Fork Carson River near Muller Lane downstream transect (SDT). 
Table 3. Summary of basic hydrologic data collected along East Fork Carson River study reach in 2010 and study reach and subreach in 2012, Carson Valley, west-central Nevada.

[DOC, dissolved organic carbon; ft, foot; GPS, global positioning system; MP, measuring point; SDT, East Fork Carson River near Muller Lane downstream transect; SMT, East Fork Carson River near Muller Lane middle-stream transect; SUT, East Fork Carson River near Muller Lane upstream transect]

\begin{tabular}{|c|c|c|c|c|}
\hline Data type & $\begin{array}{l}\text { Study reach transects } \\
2010\end{array}$ & $\begin{array}{l}\text { Study reach transects } \\
2012\end{array}$ & Comments & References \\
\hline $\begin{array}{l}\text { Observation } \\
\text { wells }\end{array}$ & $\begin{array}{l}\text { Ten shallow drive-point wells were } \\
\text { installed. Top of well screens were } \\
2.0 \mathrm{ft} \text { below land surface (the } \\
\text { streambed), and screen lengths } \\
\text { were } 1.1 \mathrm{ft} \text {. Additional well } \\
\text { information is given in table } 1 .\end{array}$ & $\begin{array}{l}\text { Thirteen drive-point wells installed. Top } \\
\text { of well screens ranged from } 2.0 \text { to } 5.9 \mathrm{ft} \\
\text { below land surface, and screen lengths } \\
\text { were } 1.2 \mathrm{ft} \text {. Additional well information } \\
\text { given in table } 1 .\end{array}$ & $\begin{array}{l}\text { Installed wells using a post driver. } \\
\text { Installed wells perpendicular to } \\
\text { stream in } 2010 \text { to define well } \\
\text { transect } 1 \text { (upstream), well transect } 2 \\
\text { (middle-stream), and well transect } 3 \\
\text { (downstream). Installed wells } \\
\text { perpendicular to stream in } 2012 \text { to } \\
\text { define well transect } 4 \text { (upper), well } \\
\text { transect } 2 \text { (middle-stream), and well } \\
\text { transect } 5 \text { (lower). }\end{array}$ & - \\
\hline $\begin{array}{l}\text { High precision } \\
\text { GPS and laser } \\
\text { levels }\end{array}$ & $\begin{array}{l}\text { High precision GPS was used to } \\
\text { determine the altitude and location } \\
\text { of observation well measuring } \\
\text { points (MPs) and stream stilling } \\
\text { well MPs. }\end{array}$ & $\begin{array}{l}\text { High precision GPS was used to } \\
\text { determine the altitude of the reference } \\
\text { datum and location of well. High } \\
\text { precision laser levels were used to } \\
\text { determine MP altitudes of wells and } \\
\text { the stream stilling well relative to the }\end{array}$ & $\begin{array}{l}\text { MP altitudes were used to determine } \\
\text { groundwater levels at observation } \\
\text { wells and stream stage at stilling } \\
\text { wells. Well locations were used to } \\
\text { determine distance between wells and } \\
\text { transects. }\end{array}$ & - \\
\hline
\end{tabular}

\section{Groundwater Periodic measurements were} level conducted at all wells using either measurements an electric tape or folding ruler.
Stream stage Periodic measurements were measurements conducted at SUT, SMT, SDT. at stream Stilling wells were attached to transects midstream wells (UMS8, MMS5,

DMS2) and used to make stream

stage measurements.

\section{reference datum.}

(1) Periodic measurements were conducted at all wells using a steel tape.

(2) Continuous measurements were made at five wells (URBFS5,

MRB9, MRBMFS10, MRBFFS12, DRBFS20). Data was collected at 15-minute intervals from September 15 to November 29, 2012. Continuous measurements were made with a submersible pressure transducer.

(1) Periodic measurements were conducted at SMT. A stilling well was attached to well MMS8 and used for stream stage measurements at SMT.

(2) Continuous measurements were made at SMT stilling well. Data was collected at 15-minute intervals from September 15 to November 29, 2012.

(3) Periodic measurements were conducted at wells in the stream when the well was surrounded by water.
The water level in the well was

Cunningham and Schalk (2011)

measured from the well MP to the water level.

Stream stages at the stilling wells were measured from the stilling well MP to the stream surface inside the stilling well using an electric tape in 2010 and a steel tape in 2012. During 2012, the stream stage was measured at wells surrounded with water by measuring from the well MP to the stream surface using a folding ruler. Continuous measurements were made with submersible pressure transducers. 
Table 3. Summary of basic hydrologic data collected along East Fork Carson River study reach in 2010 and study reach and subreach in 2012 , Carson Valley, west-central Nevada.-Continued

[DOC, dissolved organic carbon; ft, foot; GPS, global positioning system; MP, measuring point; SDT, East Fork Carson River near Muller Lane downstream transect; SMT, East Fork Carson River near Muller Lane middle-stream transect; SUT, East Fork Carson River near Muller Lane upstream transect]

\begin{tabular}{|c|c|c|c|c|}
\hline Data type & $\begin{array}{l}\text { Study reach transects } \\
2010\end{array}$ & $\begin{array}{c}\text { Study reach transects } \\
2012\end{array}$ & Comments & References \\
\hline $\begin{array}{l}\text { Stream } \\
\text { discharge } \\
\text { measurements }\end{array}$ & $\begin{array}{l}\text { Instantaneous discharge } \\
\text { measurements were made at } \\
\text { SUT, SMT, and SDT prior to } \\
\text { collection of stream samples } \\
\text { except in July at SDT when the } \\
\text { discharge measurement was made } \\
\text { after sample collection. Stream } \\
\text { discharge measurements at SUT, } \\
\text { SMT, and SDT were made on } \\
\text { different days or made at two sites } \\
\text { in a given day. }\end{array}$ & $\begin{array}{l}\text { Instantaneous discharge measurements } \\
\text { were made at SUT, SMT, and SDT prior } \\
\text { to or after collection of stream samples. } \\
\text { Stream discharge measurements were } \\
\text { made at SUT, SMT, SDT at the same } \\
\text { time. }\end{array}$ & $\begin{array}{l}\text { The percent error used to estimate } \\
\text { measurement error for each discharge } \\
\text { measurement based on the discharge } \\
\text { measurement accuracy is as follows: } \\
\text { For good accuracy } 5 \text { percent of the } \\
\text { discharge value was used, for fair } \\
\text { accuracy } 8 \text { percent of discharge } \\
\text { value was used, for poor accuracy } \\
10 \text { percent of discharge value was } \\
\text { used. }\end{array}$ & $\begin{array}{l}\text { Rantz and others (1982), } \\
\text { Sauer and Meyer (1992), } \\
\text { Turnipseed and Sauer (2010) }\end{array}$ \\
\hline $\begin{array}{l}\text { Groundwater- } \\
\text { quality field } \\
\text { parameters- } \\
\text { periodic }\end{array}$ & $\begin{array}{l}\text { Groundwater in } 10 \text { wells was } \\
\text { measured for dissolved oxygen, } \\
\text { temperature, specific conductance, } \\
\text { and } \mathrm{pH} \text {. }\end{array}$ & $\begin{array}{l}\text { Groundwater in } 13 \text { wells was measured } \\
\text { for dissolved oxygen, temperature, } \\
\text { specific conductance, and } \mathrm{pH} \text {. }\end{array}$ & $\begin{array}{l}\text { Field parameters were monitored prior } \\
\text { to collection of groundwater samples. }\end{array}$ & $\begin{array}{l}\text { USGS National Field Manual for } \\
\text { the Collection of Water-Quality } \\
\text { Data (U.S. Geological Survey, } \\
\text { variously dated) }\end{array}$ \\
\hline $\begin{array}{l}\text { Groundwater- } \\
\text { quality field } \\
\text { parameters- } \\
\text { continuous }\end{array}$ & $\begin{array}{l}\text { Groundwater in } 10 \text { wells was } \\
\text { measured for water temperature } \\
\text { every } 15 \text { minutes. }\end{array}$ & - & - & $\begin{array}{l}\text { USGS National Field Manual for } \\
\text { the Collection of Water-Quality } \\
\text { Data (U.S. Geological Survey, } \\
\text { variously dated) }\end{array}$ \\
\hline $\begin{array}{l}\text { Groundwater- } \\
\text { quality } \\
\text { samples } \\
\text { at wells- } \\
\text { Multiple } \\
\text { sampling } \\
\text { efforts in } \\
2010 \text { and } \\
2012\end{array}$ & $\begin{array}{l}\text { (1) Nutrient }{ }^{1} \text { and dissolved chloride } \\
\text { samples from } 10 \text { wells were } \\
\text { collected during three sampling } \\
\text { events - late July, early September, } \\
\text { mid-October. } \\
\text { (2) Nutrient }{ }^{1} \text { and dissolved chloride } \\
\text { samples were collected and field } \\
\text { parameters measuremented at three } \\
\text { well transect } 2 \text { (middle-stream) } \\
\text { wells every } 2 \text { hours over } 24 \text { hours } \\
\text { in early September. }\end{array}$ & $\begin{array}{l}\text { (1) Nutrient }{ }^{1} \text { and dissolved chloride } \\
\text { samples at } 13 \text { wells were collected } \\
\text { during three sampling events_late } \\
\text { July/early August, late August, late } \\
\text { September. } \\
\text { (2) Dissolved organic carbon (DOC) } \\
\text { samples were collected at } 8 \text { wells } \\
\text { during late September. } \\
\text { (3) Dissolved nitrite samples were } \\
\text { collected at } 13 \text { wells in late September } \\
\text { and from } 2 \text { wells in late July/early } \\
\text { August. }\end{array}$ & $\begin{array}{l}\text { In } 2010 \text {, groundwater samples at a } \\
\text { given well transect were collected } \\
\text { on the same day as stream samples } \\
\text { from the stream site near the given } \\
\text { well transect (except URB9 was } \\
\text { sampled one day later in October). } \\
\text { In } 2012 \text {, groundwater samples were } \\
\text { collected at wells in the same transect } \\
\text { on the same day (except during } \\
\text { the late August sampling event at } \\
\text { well transect } 2 \text { (middle-stream) } \\
\text { wells which took } 2 \text { days). In } 2012 \text {, } \\
\text { groundwater samples from a given } \\
\text { well transect and stream samples } \\
\text { collected near the given well transect } \\
\text { were not collected on the same day. } \\
\text { Nutrient, chloride, and DOC samples } \\
\text { were analyzed by the USGS National } \\
\text { Water Quality Laboratory in Denver, } \\
\text { Colorado. }\end{array}$ & $\begin{array}{l}\text { Sample collection methods: USGS } \\
\text { National Field Manual for the } \\
\text { Collection of Water-Quality } \\
\text { Data (U.S. Geological Survey, } \\
\text { variously dated) } \\
\text { Nutrient and chloride laboratory } \\
\text { methods: Fishman and Friedman } \\
\text { (1989), Fishman (1993), O’Dell } \\
\text { (1993), Patton and Truitt (2000), } \\
\text { Patton and Kryskalla (2011) } \\
\text { DOC laboratory methods: Brenton } \\
\text { and Arnett (1993) }\end{array}$ \\
\hline
\end{tabular}


Table 3. Summary of basic hydrologic data collected along East Fork Carson River study reach in 2010 and study reach and subreach in 2012, Carson Valley, west-central Nevada.-Continued

[DOC, dissolved organic carbon; ft, foot; GPS, global positioning system; MP, measuring point; SDT, East Fork Carson River near Muller Lane downstream transect; SMT, East Fork Carson River near Muller Lane middle-stream transect; SUT, East Fork Carson River near Muller Lane upstream transect]

\begin{tabular}{|c|c|c|c|c|}
\hline Data type & $\begin{array}{l}\text { Study reach transects } \\
2010\end{array}$ & $\begin{array}{l}\text { Study reach transects } \\
2012 \\
\end{array}$ & Comments & References \\
\hline $\begin{array}{l}\text { Stream water- } \\
\text { quality field } \\
\text { parameters- } \\
\text { periodic }\end{array}$ & $\begin{array}{l}\text { Dissolved oxygen, temperature, } \\
\text { specific conductance, and } \mathrm{pH} \text { were } \\
\text { measured during or after collection } \\
\text { of stream samples. }\end{array}$ & $\begin{array}{l}\text { Dissolved oxygen, temperature, specific } \\
\text { conductance, and } \mathrm{pH} \text { were measured } \\
\text { during or after collection of stream } \\
\text { samples. }\end{array}$ & - & $\begin{array}{l}\text { USGS National Field Manual for } \\
\text { the Collection of Water-Quality } \\
\text { Data (U.S. Geological Survey, } \\
\text { variously dated) }\end{array}$ \\
\hline $\begin{array}{l}\text { Stream water- } \\
\text { quality field } \\
\text { parameters- } \\
\text { continuous }\end{array}$ & $\begin{array}{l}\text { Dissolved oxygen, temperature, } \\
\text { specific conductance, and pH } \\
\text { were measured at SDT. Data } \\
\text { was collected at 5- to } 10 \text {-minute } \\
\text { intervals from August } 3 \text { to } \\
\text { September } 29,2010 \text {. Water } \\
\text { temperature was measured at SUT, } \\
\text { SMT, and SDT every } 15 \text { minutes. }\end{array}$ & $\begin{array}{l}\text { Dissolved oxygen, temperature, specific } \\
\text { conductance, and pH were measured } \\
\text { at SDT. Data was collected at } 5 \text { - to } \\
10 \text {-minute intervals from July } 20 \text { to } \\
\text { August } 17,2012 \text {. }\end{array}$ & $\begin{array}{l}\text { The dissolved oxygen probe used } \\
\text { in } 2010 \text { biofouled from detached } \\
\text { benthic algae and had calibration drift } \\
\text { problems resulting in some dissolved } \\
\text { oxygen data with poor accuracy. An } \\
\text { optical dissolved oxygen probe was } \\
\text { used in } 2012 \text { resulting in minimal } \\
\text { biofouling and calibration drift, and } \\
\text { improved accuracy. }\end{array}$ & Wagner and others (2006) \\
\hline $\begin{array}{l}\text { Stream water- } \\
\text { quality } \\
\text { samples }\end{array}$ & $\begin{array}{l}\text { Nutrient }^{1} \text { and dissolved chloride } \\
\text { samples were collected at SUT, } \\
\text { SMT, and SDT during three } \\
\text { sampling events - late July, early } \\
\text { September, and mid-October. }\end{array}$ & $\begin{array}{l}\text { (1) Nutrient }{ }^{1} \text { and dissolved chloride } \\
\text { samples were collected at SUT, SMT, } \\
\text { and SDT during three sampling } \\
\text { events-late July/early August, late } \\
\text { August, and late September. } \\
\text { (2) DOC sample was collected at SMT in } \\
\text { late September. } \\
\text { (3) Dissolved nitrite samples were } \\
\text { collected at SUT, SMT, and SDT in late } \\
\text { September, and at SMT in late July/ } \\
\text { early August. }\end{array}$ & $\begin{array}{l}\text { During } 2010, \text { stream samples at } \\
\text { a stream site near a given well } \\
\text { transect were collected on same } \\
\text { day as groundwater-quality samples } \\
\text { for given well transect (with one } \\
\text { exception). During 2012, stream } \\
\text { samples at SUT, SMT, SDT were } \\
\text { collected on same day. Nutrient, } \\
\text { chloride, and DOC samples analyzed } \\
\text { by the USGS National Water Quality } \\
\text { Laboratory in Denver, Colorado. }\end{array}$ & $\begin{array}{l}\text { Sample collection methods: USGS } \\
\text { National Field Manual for the } \\
\text { Collection of Water-Quality } \\
\text { Data (U.S. Geological Survey, } \\
\text { variously dated) } \\
\text { Nutrient and chloride laboratory } \\
\text { methods: Fishman and Friedman } \\
\text { (1989), Fishman (1993), O’Dell } \\
\text { (1993), Patton and Truitt (2000), } \\
\text { Patton and Kryskalla (2011) } \\
\text { DOC laboratory methods: Brenton } \\
\text { and Arnett (1993) }\end{array}$ \\
\hline
\end{tabular}

${ }^{1}$ Nutrient laboratory analysis included total ammonia plus organic nitrogen (total Kjeldahl nitrogen), dissolved nitrate plus nitrite, dissolved ammonia, total phosphorus, and dissolved orthophosphate. Total nitrogen determined by adding dissolved nitrate plus nitrite to total ammonia plus organic nitrogen. Total organic nitrogen determined by subtracting dissolved ammonia from total ammonia plus organic nitrogen. Dissolved nitrate determined by subtracting dissolved nitrite from dissolved nitrate plus nitrite. Particulate phosphorus estimated by subtracting dissolved orthophosphate from total phosphorus. 
Stream water-quality samples were collected at SUT, SMT, and SDT, and groundwater water-quality samples were collected from wells located at three well transects (well transect 1 [upstream], well transect 2 [middle-stream], and well transect 3 [downstream]) during three sampling events in 2010. Groundwater water-quality samples were collected from wells at three well transects (well transect 4 [upper], well transect 2 [middle-stream], and well transect 5 [lower]) during three sampling events in 2012, in addition to stream waterquality samples collected at SUT, SMT, and SDT. Sampling events in 2010 and 2012 occurred at nearly the same time of year-late July/early August, late August/early September, and late September/mid-October (table 3). Nutrient and dissolved chloride samples were collected at all wells and stream sites during each sampling event; dissolved organic carbon (DOC) and dissolved nitrite (hereafter called nitrite) samples were collected at selected wells and stream sites during sampling events in 2012. Nutrient samples were used to determine groundwater nutrient loads to the EFCR and stream nutrient loads. The chloride samples were used in mass balance calculations to estimate the volumetric rate of groundwater discharge to the stream. Prior to collecting groundwater samples, water-quality field parameters were monitored for specific conductance (SC), temperature, dissolved oxygen (DO), and $\mathrm{pH}$. Instantaneous stream discharge measurements were collected on the same day that stream water-quality samples were collected for the same stream site, and waterquality field parameters were monitored for SC, temperature, $\mathrm{DO}$, and $\mathrm{pH}$ during stream water-quality sample collection. Moreover, to better understand diurnal changes in stream water-quality field parameters and to characterize the extent and severity of exceedances of the State of Nevada waterquality standards, $\mathrm{SC}, \mathrm{DO}, \mathrm{pH}$, and temperature were continuously monitored every 5 to 15 minutes at SDT during the measurement period of August 3 to September 29, 2010, and July 20 to August 17, 2012 (fig. 7).

Field water-quality measurements and nutrient and dissolved chloride concentrations in groundwater and stream samples collected in 2010 are summarized in appendix 1, and groundwater and stream samples collected in 2012 (along with DOC and nitrite concentrations) are in appendix 2. Quality control for groundwater and stream sampling consisted of the collection and analysis of (1) field blanks to check for potential contamination in environmental water samples from field and laboratory procedures and (2) split replicate samples to check for variability in environmental water samples from sample processing methods and laboratory analyses. Additional details on quality control procedures applied for the collection of basic water-quality samples (nutrients, dissolved chloride, DOC, and nitrite) are summarized in appendix 3. All basic water-quality samples were collected using established protocols in the USGS National Field Manual (U.S. Geological Survey, variously dated; table 3).

Hydrologic and water-quality data collected in 2010 and 2012 are stored in the USGS NWIS database

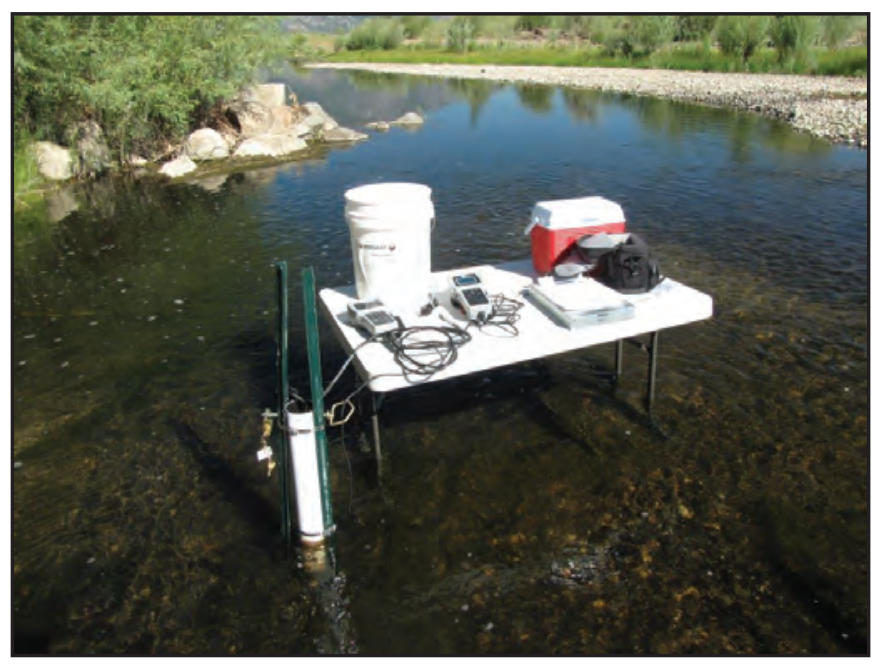

Figure 7. Water-quality sonde deployment at stream site East Fork Carson River near Muller Lane downstream transect (SDT), East Fork Carson River, Carson Valley, west-central Nevada.

(https://waterdata.usgs.gov/nv/nwis/nwis). A separate electronic data release for stream profiles of specific conductance and for stream continuous water-quality data from SDT are available in ScienceBase (Alvarez and others, 2018a, b). The NDEP stream continuous water-quality data for daily maximum, minimum, and average at SDT is available from the NDEP Water Quality Data Warehouse (https://nevadawaterquality.ndep.nv.gov/).

\section{Methods of Data Analysis}

Nutrient contributions to EFCR from groundwater, denitrification and sources of nitrate in groundwater, and assessment of algae in EFCR were evaluated using a number of analyses in this study. Denitrification, or the reduction of nitrate to nitrogen gas $\left(\mathrm{N}_{2}\right)$, was evaluated using nitrogen and argon dissolved-gas samples and nitrogen and oxygen isotope samples collected from multiple wells. Sources of nitrate in groundwater were evaluated through collection of groundwater samples analyzed for organic wastewater compounds and nitrogen and oxygen isotope ratios of nitrate. Algal conditions were characterized in terms of nuisance levels and stream trophic status through the collection of periphyton biomass samples at multiple locations, analysis for chlorophyll $a$, and qualitative estimates of percent cover by periphyton algae. Groundwater discharge to EFCR was quantified using several methods to calculate the volumetric flow rate of groundwater discharge to the EFCR in the summers of 2010 and 2012. Groundwater and stream loads were calculated based on groundwater nutrient concentrations and stream nutrient concentrations, respectively, and discharge. 
Dissolved-gas, isotope, and organic wastewater compound data are summarized in appendixes 4, 2, and 5 , respectively, and all datasets, including stream-stage and stream discharge measurements used, in part, for groundwater discharge estimates, are archived in the USGS NWIS database. Quality control procedures applied during sampling for dissolved gas, isotopes, and organic wastewater compounds are summarized in appendix 3 .

\section{Denitrification in Groundwater}

Denitrification in groundwater was suspected based primarily on low dissolved oxygen concentrations measured in groundwater at well transect 2 (middle-stream) in 2010 and potentially quantified from dissolved-gas samples collected from 12 observation wells along well transects 4 (upper), 2 (middle-stream), and 5 (lower) in late September 2012; two dissolved-gas samples were collected consecutively at each observation well (table 1). Low dissolved oxygen concentrations may be used as an indicator for potentially denitrifying conditions if less than $0.5 \mathrm{mg} / \mathrm{L}$, but ideally below $0.2 \mathrm{mg} / \mathrm{L}$ (van Haandel and van der Lubbe, 2007; Mahler and others, 2011). The range of dissolved oxygen measured in 2010 in groundwater at well transect 2 (middle-stream) wells indicated dissolved oxygen concentrations were near the threshold for denitrification. Dissolved-gas samples were collected using procedures by U.S. Geological Survey (2014) with one modification - a metal bucket was filled halfway with sample water, and a glass $150-\mathrm{mL}$ sample bottle was placed in the bucket. The discharge tubing from the well was placed at the bottom of the sample bottle and was allowed to overfill the bottle and fill up the bucket. Dissolved-gas samples were analyzed by the USGS Groundwater Dating Laboratory in Reston, Virginia, for concentration of argon (Ar), nitrogen $\left(\mathrm{N}_{2}\right)$, oxygen, methane, and carbon dioxide gas in water (Weiss, 1970; Busenberg and others, 1998; U.S. Geological Survey, 2014).

Nitrogen and argon dissolve in water that is in contact with the atmosphere, and their concentration depends on the temperature and atmospheric pressure when gas exchange occurs (Manning, 2009). Dissolved nitrogen gas in groundwater behaves conservatively if denitrification is not occurring. Argon is a noble gas that is chemically inert, and its concentration generally does not change along groundwater flow paths; therefore, once the recharge water enters the saturated zone, argon no longer exchanges with the atmosphere (Manning, 2009; Harte, 2013). When the amount of dissolved nitrogen and argon gas in a groundwater sample is higher than what would be expected based on dissolution equilibrium with the atmosphere, this "excess air" is likely from air bubbles in water infiltrating the saturated zone (Heaton and Vogel, 1981) or from air trapped below a rising water table (Busenberg and others, 2014). Dissolved nitrogen gas in groundwater samples therefore could be from (1) nitrogen gas added to the water during recharge while in equilibrium with air, (2) nitrogen gas added during recharge by incorporation of excess air, and (3) non-atmospheric excess nitrogen gas added after recharge by denitrification (Lindsey and others, 2003, p. 32). The amount of non-atmospheric excess nitrogen gas in a groundwater sample cannot be calculated directly from only nitrogen and argon gas data and must be estimated (Lindsey and others, 2003, p. 32).

The occurrence of denitrification was assessed by estimating the amount of excess air with a back-solving routine based on the estimated recharge elevation of the sampled groundwater and the dissolved $\mathrm{N}_{2}$ and $\mathrm{Ar}$ concentrations in the groundwater samples (Busenberg and others, 1993). Two recharge elevations were used: 8,500 ft, which is the average elevation of the mountains in Carson Valley that form the southeast boundary of the EFCR drainage, and $4700 \mathrm{ft}$, which is the elevation in Carson Valley near the study observation wells. Two different elevations were used because the recharge of groundwater is probably from a mixture of water recharged in the mountains and water recharged on the valley floor from stream infiltration, agricultural irrigation, or landscape irritation. The backsolving routine iterates on recharge temperature at the estimated recharge elevation until the amount of excess air calculated separately from $\mathrm{N}_{2}$ and Ar sample data are the same. Excess air was calculated as Ar concentration measured in the water sample by the laboratory minus the calculated amount of Ar in the sample added during recharge at the given recharge elevation. Excess air was also calculated as the $\mathrm{N}_{2}$ measured in the water sample by the laboratory minus the calculated amount of $\mathrm{N}_{2}$ in the sample added during recharge at the given recharge elevation, minus the estimated amount of excess $\mathrm{N}_{2}$ from denitrification. The initial calculations assume no excess $\mathrm{N}_{2}$ from denitrification. If denitrification is occurring, this leads to a warm bias in the calculated recharge temperature and an overestimation of excess air in groundwater samples (Lindsey and others, 2003). Excess $\mathrm{N}_{2}$ from denitrification can be estimated and entered in the back-solving routine by the user when the calculated recharge temperature is unrealistically high and excess air is high. Normally, recharge temperature will be similar to the mean annual air temperature (Manning, 2009). 


\section{Sources of Nitrate in Groundwater}

To support the detection of denitrification and help identify potential sources of nitrate in groundwater, nitrogen and oxygen isotope data and organic wastewater compound data were evaluated from groundwater observation wells in 2012 (table 1). Samples were collected from select wells downgradient of the residential area and along the right bank and in the middle of the EFCR at well transect 4 (upper), well transect 2 (middle-stream), and well transect 5 (lower) (fig. 6). Measurements of nitrogen and oxygen ratios $\left({ }^{15} \mathrm{~N} /{ }^{14} \mathrm{~N}\right.$ and ${ }^{18} \mathrm{O} /{ }^{16} \mathrm{O}$, respectively) of nitrate in water samples can be useful in differentiating inorganic sources (atmospheric and synthetic fertilizer) from organic sources (manure, septic waste, and wastewater effluent; Kendall, 1998; Kendall and Aravena, 2000; Crain and others, 2017). The nitrogen and oxygen isotope ratios of nitrate in water samples are reported as delta $(\delta)$ values in units of parts per thousand (per mil, \%o) relative to an international reference standard, which for $\mathrm{N}$ and $\mathrm{O}$ are atmospheric air and Vienna Standard Mean Ocean Water (VSMOW), respectively (Kendall, 1998). The $\delta$ values are computed using the equation

$$
\delta^{15} \mathrm{~N}_{\text {nitrate }} \text { or } \delta^{18} \mathrm{O}_{\text {nitrate }}=\left\{\left(R_{\text {sample }} / R_{\text {standard }}\right)-1\right\} \times 1,000
$$

where $R_{\text {sample }}$ and $R_{\text {standard }}$ represent the ratios of ${ }^{15} \mathrm{~N} /{ }^{14} \mathrm{~N}$ or ${ }^{18} \mathrm{O} /{ }^{16} \mathrm{O}$ of nitrate in the sample and standard, respectively.

Low $\delta^{15} \mathrm{~N}_{\text {nitrate }}$ values $(-5 \%$ to $+5 \%$ ) are associated with inorganic sources of nitrate (such as fertilizer) compared to higher $\delta^{15} \mathrm{~N}_{\text {nitrate }}$ values $(0 \%$ to $+25 \%$ ) associated with organic sources of nitrate (such as animal waste, wastewater, or waste disposal; Kendall and others, 2007; Crain and others, 2017). Intermediate values of $\delta^{15} \mathrm{~N}_{\text {nitrate }}$ (between $+3 \%$ and $+9 \%$ ) have either a mixture of organic and inorganic sources of nitrate or a soil organic nitrogen source (Katz and others, 1999; Kendall and others, 2007; Crain and others, 2017). One limitation of using nitrogen isotope data to identify nitrate sources is ambiguity in the data between inorganic and organic sources (Mahler and others, 2011). Another limitation is the nitrogen isotope method assumes that nitrate has not been removed by denitrification. Denitrification produces a distinctive signature on the $\delta^{15} \mathrm{~N}_{\text {nitrate }}$ versus $\delta^{18} \mathrm{O}_{\text {nitrate }}$ plots, with the slope close to 0.48 (Kendall and Aravena, 2000).

Samples for analysis of nitrogen and oxygen isotopes of nitrate were collected from eight observation wells (fig. 6; table 1). The eight samples and one replicate were collected during the September 2012 sampling event using methods described by Coplen and others (2012), except a 0.2-micrometer filter was used instead of a 0.25 -micrometer filter. Only samples with nitrate concentrations greater than $0.03 \mathrm{mg} / \mathrm{L}$ as $\mathrm{N}$ were shipped to the USGS Reston Stable Isotope Laboratory in Reston, Va. Samples were analyzed using methods described by Sigman and others (2001), Casciotti and others (2002), and Coplen and others (2004; 2012).

Groundwater samples were collected in late September 2012 from 4 observation wells at well transect 4 (upper), well transect 2 (middle-stream), and well transect 5 (lower) for analysis of 59 organic compounds that are commonly present in domestic and industrial wastewater. Concentrations are typically very low in groundwater; hence, the evaluation of organic wastewater compounds in samples from selected observation wells focused on detections rather than concentrations (Barnes and others, 2008; Mahler and others, 2011). Field sample collection of organic wastewater compounds used standard protocols, such as avoiding the use of personal care products (insect repellent, fragrances, sunscreen, and deodorant) and cleaning Teflon tubing and plate filter between samples (U.S. Geological Survey, variously dated). The organic wastewater compounds summarized in table 4 were analyzed by USGS NWQL using methods described by Zaugg and others (2007).

The analytical method for organic wastewater compounds is considered to be "information rich" (Zaugg and others, 2007) because compound identifications are determined by mass spectrometry, and criteria for the initial qualitative and then subsequent quantitative identification of each compound is based on analysis of standards for each of the compounds (Zaugg and others, 2007; Haack and Luukkonen, 2013). Information-rich methods are not restricted to censoring measurements below the long-term method detection level (LT-MDL), and all information-rich methods report estimated concentrations for positively identified compounds below the LT-MDL if other quality control criteria are met (Childress and others, 1999). However, Childress and others (1999) also recommend that data below the LT-MDL, which have an increased risk of false positives (a statement that a substance is present in a sample when it actually is not), be carefully examined with respect to laboratory and field blank data. At or above the LT-MDL, there is a 1-percent chance of a false-positive determination (Childress and others, 1999). The USGS NWQL personnel set the laboratory reporting level (LRL) generally equal to twice the LT-MDL. The laboratory reporting level limits false negative error and is set so that the probability of falsely reporting a non-detection for a sample that contained a compound at a concentration equal to or greater than the LRL is predicted to be less than or equal to 1 percent (Childress and others, 1999). The LRL and LT-MDL for the organic wastewater compounds tested are shown in table 4. 
Table 4. Organic wastewater compounds analyzed in groundwater samples collected from select groundwater wells at well transect 4 (upper), well transect 2 (middle-stream), and well transect 5 (lower), 2012, including their uses or sources and their reporting levels, East Fork Carson River, Carson Valley, west-central Nevada.

[LT-MDL, long-term method detection limit; NWIS, National Water Information System; $\mu \mathrm{g} / \mathrm{L}$, microgram per liter; \%, percent; >, greater than]

\begin{tabular}{|c|c|c|c|c|c|}
\hline Compound & $\begin{array}{c}\text { Chemical } \\
\text { abstracts service } \\
\text { (CAS) number }\end{array}$ & Possible compound uses or sources & $\begin{array}{c}\text { NWIS } \\
\text { parameter } \\
\text { code }\end{array}$ & $\begin{array}{c}\text { Laboratory } \\
\text { reporting level' } \\
(\mu \mathrm{g} / \mathrm{L})\end{array}$ & $\begin{array}{c}\text { LT-MDL } \\
(\mu \mathrm{g} / \mathrm{L})\end{array}$ \\
\hline \multicolumn{6}{|c|}{ Detergent metabolites } \\
\hline 4-Cumylphenol & $599-64-4$ & Nonionic detergent metabolite & 62060 & 0.06 & 0.03 \\
\hline 4-n-Octylphenol & $1806-26-4$ & Nonionic detergent metabolite & 62061 & 0.06 & 0.03 \\
\hline 4-tert-Octylphenol & $140-66-9$ & Nonionic detergent metabolite & 62062 & 0.14 & 0.07 \\
\hline $\begin{array}{l}\text { 4-Nonylphenol diethoxylate, sum of all } \\
\text { isomers (NP2EO) }\end{array}$ & - & Nonionic detergent metabolite & 62083 & 5 & 2.5 \\
\hline para-Nonylphenol (total) (branched) & $84852-15-3$ & Nonionic detergent metabolite & 62085 & 2 & 1 \\
\hline 4-tert-Octylphenol diethoxylate (OP2EO) & $2315-61-9$ & Nonionic detergent metabolite & 61705 & 1 & 0.5 \\
\hline $\begin{array}{l}\text { 4-tert-Octylphenol monoethoxylate } \\
\text { (OP1EO) }\end{array}$ & $2315-67-5$ & Nonionic detergent metabolite & 61706 & 1 & 0.5 \\
\hline \multicolumn{6}{|c|}{ Fragances and flavors } \\
\hline 3-Methyl-1H-indole (Skatole) & $83-34-1$ & Fragrance, stench in feces and coal tar & 62058 & 0.036 & 0.018 \\
\hline Acetophenone & $98-86-2$ & Fragrance in detergent and tobacco, flavor in beverages & 62064 & 0.4 & 0.2 \\
\hline $\begin{array}{l}\text { Acetyl hexamethyl tetrahydronaphthalene } \\
\text { (AHTN) }\end{array}$ & $21145-77-7$ & Musk fragrance (widespread usage) persistent in groundwater & 62065 & 0.028 & 0.014 \\
\hline Camphor & $76-22-2$ & Flavor, odorant, ointments & 62070 & 0.044 & 0.022 \\
\hline $\begin{array}{l}\text { Hexahydrohexamethylcyclopentabenzopyran } \\
\text { (HHCB) }\end{array}$ & $1222-05-5$ & Musk fragrance (widespread usage) persistent in groundwater & 62075 & 0.052 & 0.026 \\
\hline Indole & $120-72-9$ & Pesticide inert ingredient, fragrance in coffee & 62076 & 0.08 & 0.04 \\
\hline Isoborneol & $124-76-5$ & Fragrance in perfumery, in disinfectants & 62077 & 0.08 & 0.04 \\
\hline Isoquinoline & $119-65-3$ & Flavors and fragrances & 62079 & 0.046 & 0.023 \\
\hline Menthol & $89-78-1$ & Cigarettes, cough drops, liniment, mouthwash & 62080 & 0.32 & 0.16 \\
\hline \multicolumn{6}{|c|}{ Pesticides and degradates } \\
\hline 1,4-Dichlorobenzene & $106-46-7$ & Moth repellant, fumigant, deodorant & 34572 & 0.04 & 0.02 \\
\hline Bromacil & $314-40-9$ & Herbicide (general use pesticide), $>80 \%$ noncrop usage on grass/brush & 04029 & 0.36 & 0.18 \\
\hline Carbaryl & $63-25-2$ & Insecticide, crop and garden uses, low persistence & 82680 & 0.16 & 0.08 \\
\hline Carbazole & $86-74-8$ & Insecticide, manufacturing dyes, explosives, and lubricants & 62071 & 0.03 & 0.015 \\
\hline Chlorpyrifos & $2921-88-2$ & $\begin{array}{l}\text { Insecticide, domestic pest and termite control (domestic use restricted as } \\
\text { of 2001) }\end{array}$ & 38933 & 0.16 & 0.08 \\
\hline D-Limonene & $5989-27-5$ & Fungicide, antimicrobial, antiviral, fragrance in aerosols & 62073 & 0.08 & 0.04 \\
\hline Diazinon & $333-41-5$ & Insecticide, $>40 \%$ nonagricultural usage, ants, flies & 39572 & 0.16 & 0.08 \\
\hline
\end{tabular}


Table 4. Organic wastewater compounds analyzed in groundwater samples collected from select groundwater wells at well transect 4 (upper), well transect 2 (middle-stream), and well transect 5 (lower), 2012, including their uses or sources and their reporting levels, East Fork Carson River, Carson Valley, west-central Nevada.-Continued

[LT-MDL, long-term method detection limit; NWIS, National Water Information System; $\mu \mathrm{g} / \mathrm{L}$, microgram per liter; \%, percent; >, greater than]

\begin{tabular}{|c|c|c|c|c|c|}
\hline Compound & $\begin{array}{c}\text { Chemical } \\
\text { abstracts service } \\
\text { (CAS) number }\end{array}$ & Possible compound uses or sources & $\begin{array}{c}\text { NWIS } \\
\text { parameter } \\
\text { code }\end{array}$ & $\begin{array}{c}\text { Laboratory } \\
\text { reporting level } \\
(\mu \mathrm{g} / \mathrm{L})\end{array}$ & $\begin{array}{c}\text { LT-MDL } \\
(\mu \mathrm{g} / \mathrm{L})\end{array}$ \\
\hline \multicolumn{6}{|c|}{ Pesticides and degradates-Continued } \\
\hline Metalaxyl & $57837-19-1$ & $\begin{array}{l}\text { Herbicide, fungicide (general use pesticide), mildew, blight, pathogens, } \\
\text { golf turf }\end{array}$ & 50359 & 0.12 & 0.06 \\
\hline Metolachlor & $51218-45-2$ & Herbicide, general use pesticide, indicator of agricultural drainage & 39415 & 0.028 & 0.014 \\
\hline$N, N$-Diethyl- $m$-toluamide (DEET) & $134-62-3$ & Insecticide, urban uses, mosquito repellent & 62082 & 0.06 & 0.03 \\
\hline Prometon & $1610-18-0$ & Herbicide (noncrop only), applied prior to blacktop & 04037 & 0.12 & 0.06 \\
\hline \multicolumn{6}{|c|}{ Industrial compounds } \\
\hline 5-Methyl-1H-benzotriazole & $136-85-6$ & Antioxidant in antifreeze and deicers & 62063 & 1.2 & 0.6 \\
\hline Anthraquinone & $84-65-1$ & Manufacturing dye/textiles, seed treatment, bird repellant & 62066 & 0.16 & 0.08 \\
\hline Benzophenone & $119-61-9$ & Fixative for perfumes and soaps & 62067 & 0.08 & 0.04 \\
\hline Isophorone & $78-59-1$ & Solvent for lacquer, plastic, oil, silicone, resin & 34409 & 0.032 & 0.016 \\
\hline Isopropylbenzene (cumene) & $98-82-8$ & Manufacturing pheno/acetone, fuels and paint thinner & 62078 & 0.3 & 0.15 \\
\hline Methyl salicylate & $119-36-8$ & Liniment, food, beverage, UV-absorbing lotion & 62081 & 0.044 & 0.022 \\
\hline$p$-Cresol & $106-44-5$ & Wood preservative & 62084 & 0.08 & 0.04 \\
\hline Tetrachloroethylene & $127-18-4$ & Solvent, degreaser, veterinary anthelmintic & 34476 & 0.12 & 0.06 \\
\hline Triethyl citrate (ethyl citrate) & $77-93-0$ & Cosmetics, pharmaceuticals & 62091 & 0.16 & 0.08 \\
\hline \multicolumn{6}{|c|}{ Disinfectants and byproducts } \\
\hline Bromoform & $75-25-2$ & Wastewater ozination byproduct, military/explosives & 34288 & 0.1 & 0.05 \\
\hline Phenol & $108-95-2$ & Disinfectant, manufacturing several products, leachate & 34466 & 0.16 & 0.08 \\
\hline Triclosan & $3380-34-5$ & Disinfectant, antimicrobial (concern for acquired microbial resistance) & 62090 & 0.2 & 0.1 \\
\hline \multicolumn{6}{|c|}{ Polycyclic aromatic hydrocarbons } \\
\hline 1-Methylnaphthalene & $90-12-0$ & $2-5 \%$ of gasoline, diesel fuel, or crude oil & 62054 & 0.022 & 0.011 \\
\hline 2,6-Dimethylnaphthalene & $581-42-0$ & Present in diesel/kerosene (trace in gasoline) & 62055 & 0.06 & 0.03 \\
\hline 2-Methylnaphthalene & $91-57-6$ & $2-5 \%$ of gasoline, diesel fuel, or crude oil & 62056 & 0.036 & 0.018 \\
\hline Anthracene & $120-12-7$ & $\begin{array}{l}\text { Wood preservative, component of tar, diesel, or crude oil, } \\
\text { combustion product }\end{array}$ & 34221 & 0.01 & 0.005 \\
\hline Benzo $[a]$ pyrene & $50-32-8$ & $\begin{array}{l}\text { Regulated polycyclic aromatic hydrocarbon (PAH), used in cancer research, } \\
\text { combustion product }\end{array}$ & 34248 & 0.06 & 0.03 \\
\hline Fluoranthene & $206-44-0$ & $\begin{array}{l}\text { Component of coal tar and asphalt (only traces in gasoline or diesel fuel), } \\
\text { combustion product }\end{array}$ & 34377 & 0.024 & 0.012 \\
\hline Naphthalene & $91-20-3$ & Fumigant, moth repellent, major component & 34443 & 0.04 & 0.02 \\
\hline
\end{tabular}


Table 4. Organic wastewater compounds analyzed in groundwater samples collected from select groundwater wells at well transect 4 (upper), well transect 2 (middle-stream), and well transect 5 (lower), 2012, including their uses or sources and their reporting levels, East Fork Carson River, Carson Valley, west-central Nevada.-Continued

[LT-MDL, long-term method detection limit; NWIS, National Water Information System; $\mu \mathrm{g} / \mathrm{L}$, microgram per liter; \%, percent; >, greater than]

\begin{tabular}{|c|c|c|c|c|c|}
\hline Compound & $\begin{array}{c}\text { Chemical } \\
\text { abstracts service } \\
\text { (CAS) number }\end{array}$ & Possible compound uses or sources & $\begin{array}{c}\text { NWIS } \\
\text { parameter } \\
\text { code }\end{array}$ & $\begin{array}{c}\text { Laboratory } \\
\text { reporting level } \\
(\mu \mathrm{g} / \mathrm{L})\end{array}$ & $\begin{array}{c}\text { LT-MDL } \\
(\mu \mathrm{g} / \mathrm{L})\end{array}$ \\
\hline \multicolumn{6}{|c|}{ Polycyclic aromatic hydrocarbons-Continued } \\
\hline Phenanthrene & $85-01-8$ & Manufacturing explosives, component of tar, diesel & 34462 & 0.016 & 0.008 \\
\hline Pyrene & $129-00-0$ & $\begin{array}{l}\text { Component of coal tar and asphalt (only traces in gasoline or diesel fuel), } \\
\text { combustion product }\end{array}$ & 34470 & 0.042 & 0.021 \\
\hline \multicolumn{6}{|c|}{ Flame retardants and plasticizers } \\
\hline Tris(2-chloroethyl)phosphate & $115-96-8$ & Plasticizer, flame retardant & 62087 & 0.1 & 0.05 \\
\hline Tris(dichloroisopropyl)phosphate & $13674-87-8$ & Flame retardant & 62088 & 0.16 & 0.08 \\
\hline Tributyl phosphate & $126-73-8$ & Antifoaming agent, flame retardant & 62089 & 0.16 & 0.08 \\
\hline Triphenyl phosphate & $115-86-6$ & Plasticizer, resin, wax, finish, roofing paper, flame retardant & 62092 & 0.12 & 0.06 \\
\hline Tris(2-butoxyethyl)phosphate & $78-51-3$ & Flame retardant & 62093 & 0.8 & 0.4 \\
\hline \multicolumn{6}{|c|}{ Plant sterols } \\
\hline beta-Sitosterol & $83-46-5$ & Plant sterol & 62068 & 4 & 2 \\
\hline beta-Stigmastanol & $19466-47-8$ & Plant sterol & 62086 & 2.6 & 1.3 \\
\hline \multicolumn{6}{|c|}{ Animal sterols } \\
\hline Cholesterol & $57-88-5$ & Often a fecal indicator, also a plant sterol & 62072 & 2 & 1 \\
\hline 3-beta-Coprostanol & $360-68-9$ & Carnivore fecal indicator & 62057 & 1.8 & 0.9 \\
\hline \multicolumn{6}{|c|}{ Nonprescription pharmaceuticals and metabolites } \\
\hline Caffeine & $58-08-2$ & Beverages, diuretic, very mobile/biodegradable & 50305 & 0.06 & 0.03 \\
\hline Cotinine & $486-56-6$ & Primary nicotine metabolite & 62005 & 0.8 & 0.4 \\
\hline
\end{tabular}

${ }^{1}$ Reporting level is either the laboratory reporting level or the interim reporting level. 


\section{Periphyton Biomass}

Measurement of algal biomass is common in many stream studies and is important in studies that involve nutrient enrichment (Hambrook Berkman and Canova, 2007). Algae grow in streams as periphyton, which are attached to a substrate, or as phytoplankton, which are unattached and carried in the stream current (Moulton and others, 2002). In this study, the focus was on periphyton. Algal biomass in a stream is estimated by quantifying chlorophyll $a(\operatorname{chl}-a)$ and carbon biomass, the latter as ash-free dry mass (AFDM). Chlorophyll $a$ provides a measure of the amount of active algal biomass as periphyton present per area of streambed (Hambrook Berkman and Canova, 2007). The chl- $a$ procedure measures photosynthetic pigment common to all types of algae, whereas the AFDM procedure measures the carbon biomass associated with an algal sample. The AFDM analysis measures the difference in mass of a dried algae sample after organic matter in the sample has been incinerated (Hambrook Berkman and Canova, 2007). Chlorophyll is the green molecule in plant cells and is essential in photosynthesis, and chl- $a$, a specific form of chlorophyll, is one of the most commonly used estimators of algal biomass in lakes and streams (Hambrook Berkman and Canova, 2007).

Periphyton biomass samples were collected by NDEP at SUT, SMT, and SDT in 2010 and 2012; sampling events were performed during the summer to characterize algae conditions during a potential period of maximum growth and percent cover. Near each stream site, a stream reach was selected with uniform cobble substrate conditions that typically varied in length from 100 to $250 \mathrm{ft}$ depending upon conditions at the site. In accordance with protocols presented by Moulton and others (2002), each reach was divided into five sampling sections, and periphyton samples were collected using one of three methods - SG-92, top-rock scrape, or gravel samplerdepending on site conditions. The collection and processing of periphyton biomass samples followed procedures outlined in Moulton and others (2002), except for the recommended volume of the composited algae-water slurry. Because of the high algae levels during sampling events, the recommended maximum composited algae-water slurry volume typically was exceeded. Periphyton biomass samples were analyzed for chl- $a$ concentration and AFDM by USGS NWQL following methods described by Britton and Greeson (1989) and Arar and Collins (1997).

In 2010 at each stream reach, the SG-92 or top-rock scrape methods were used to collect a composite periphyton sample from 5 substrate rocks representative of average conditions within each of the 5 sampling sections (for a total of 25 rocks per composite sample). In 2012, in order to minimize the algae-water slurry volume collected, the toprock scape method (at SDT) was used to collect the composite periphyton sample from 10 substrate rocks, whereas the gravel sampler method (at SUT and SMT) was used to collect a composite periphyton sample from the gravel substrate at 5-10 locations during each sampling event. The surface area of the rock where algae is removed is used in the calculation of chl- $a$ concentrations. For samples collected by the top-rock scrape method, the area of the rock top surface $\left(\right.$ in $\left.\mathrm{cm}^{2}\right)$ was estimated using the following equation taken from Graham and others (1988):

Surface area $=1.15(L \times W+W \times H+H \times L) / 2$

where
$L \quad$ is the length of rock, in centimeters $(\mathrm{cm})$;
$W \quad$ is the width of rock, in cm; and
$H$ is the height of rock, in $\mathrm{cm}$.

Methods for calculating the surface area using the SG-92 and gravel sampler methods are listed in Moulton and others (2002).

The extent of periphyton coverage of a streambed and the concentration of chl- $a$ can be important indicators of algal biomass problems and stream health (U.S. Environmental Protection Agency, 2000). Although the State of Nevada has not set water-quality standards for periphyton algal biomass, the State has been investigating the potential for incorporating criteria such as percent cover of substrate by periphyton and chl- $a$ concentrations into proposed standards (Randy Pahl, NDEP, oral commun., 2014). For purposes of this report, a percent cover of algae threshold of 50 percent or chl- $a$ concentration threshold of 150 milligrams per square meter $\left(\mathrm{mg} / \mathrm{m}^{2}\right)$ were used to assess whether algal conditions reached a nuisance level in the EFCR.

Qualitative estimates of percent cover by periphyton algae were made at all three stream sites in 2010 and 2012 following procedures used by NDEP as part of a Level I assessment (Nevada Division of Environmental Protection, 2009). The NDEP procedure calls for visual estimates of substrate coverage by periphyton algae into four categories: less than 25 percent, 25 to 50 percent, 50 to 75 percent, or greater than 75 percent. These techniques have been developed by NDEP to serve as a rapid assessment tool for identifying algal conditions for wadeable streams throughout the State. However, current (2016) literature provides no clearly defined levels of percent cover at which periphyton substrate coverage reaches nuisance levels and impairment may be assumed to occur. Some researchers have identified algae cover levels of 20-40 percent as affecting recreation and aquatic life uses (Welch and Jacoby, 2004). As part of New Mexico nutrient assessment protocols, the "greater than 50\%" cover is used to determine whether or not a Level II assessment (a more detailed assessment including algal biomass measurements) is needed (New Mexico Environmental Department, 2011). Maine has proposed algae cover criteria of 20-35 percent depending upon the waterbody classification (Maine Department of Environmental Protection, 2012). According to data from Biggs and Kilroy (2000) for the Waipara River in New Zealand, 50-percent cover conditions were approximately comparable to algal biomass levels of about $200 \mathrm{mg} / \mathrm{m}^{2}$ for chl- $a$, a value at the upper end of suggested chl- $a$ thresholds in Welch and Jacoby (2004). 
Welch and Jacoby (2004) recommended using chl- $a$ levels between 50 and $200 \mathrm{mg} / \mathrm{m}^{2}$ to assess whether algal conditions have reached a critical nuisance level and conclude that $150 \mathrm{mg} / \mathrm{m}^{2}$ may serve as an appropriate threshold for evaluating stream nuisance conditions. In a more recent effort, Suplee and others (2009) conducted surveys to evaluate public perception of streambed algae levels in Montana's rivers and streams and found that mean chl- $a$ levels less than or equal to $150 \mathrm{mg} / \mathrm{m}^{2}$ were deemed desirable for recreation by the public majority.

\section{Trophic State}

Classifying a stream by trophic state is a useful method for characterizing the eutrophic conditions of the stream. Trophic state defines where a stream lies along a spectrum from a stream that is extremely pristine to one that has excessive plant growth. Typical stream trophicstate classifications, ranging from least to most productive, are oligotrophic, mesotrophic, and eutrophic (Dodds and others, 1998). Dodds and others (1998) developed a trophic classification scheme for streams based upon chl- $a$, nitrogen, and phosphorus (P) levels (table 5). Because of difficulties in relating algae levels to nutrient concentrations in moving waters, the U.S. Environmental Protection Agency (2000) has recommended that trophic-state classifications for periphytondominated streams are most appropriately based upon benthic algae levels. In this study, classification of the trophic state of the EFCR is based on chl- $a$ concentrations listed in table 5 and based on Dodds and others (1998) and U.S. Environmental Protection Agency (2000, p. 27).

Table 5. Summary of trophic-state classification scheme used for samples collected from the East Fork Carson River in Carson Valley, west-central Nevada.

$\left[\mathrm{mg} / \mathrm{L}\right.$, milligram per liter; $\mathrm{mg} / \mathrm{m}^{2}$, milligram per square meter; $<$, less than; $>$, greater than]

\begin{tabular}{lccc}
\hline \multicolumn{1}{c}{ Parameter } & $\begin{array}{c}\text { Oligotrophic } \\
\text { or low } \\
\text { productivity }\end{array}$ & $\begin{array}{c}\text { Mesotrophic }^{1} \\
\text { or moderate } \\
\text { productivity }\end{array}$ & $\begin{array}{c}\text { Eutrophic }^{1} \\
\text { or high } \\
\text { productivity }\end{array}$ \\
\hline $\begin{array}{c}\text { Mean benthic } \\
\text { chlorophyll } a \\
\left(\mathrm{mg} / \mathrm{m}^{2}\right)\end{array}$ & $<20$ & $20-70$ & $>70$ \\
$\begin{array}{c}\text { Maximum benthic } \\
\text { chlorophyll } a \\
\left(\mathrm{mg} / \mathrm{m}^{2}\right)\end{array}$ & $<60$ & $60-200$ & $>200$ \\
$\begin{array}{l}\text { Total nitrogen }(\mathrm{mg} / \mathrm{L}) \\
\begin{array}{c}\text { Total phosphorus } \\
(\mathrm{mg} / \mathrm{L})\end{array}\end{array}$ & $<0.70$ & $0.70-1.50$ & $>1.50$ \\
\hline
\end{tabular}

${ }^{1}$ From Dodds and others (1998).

\section{Autotrophic Index}

The autotrophic index is useful in examining the relation between the autotrophic and heterotrophic composition of the periphyton community (Collins and Weber, 1978). The autotrophic index is the ratio of AFDM to chl- $a$ concentrations. Autotrophs, such as algae and plants, are those organisms that are able to make their own food (energycontaining organic molecules such as fats, carbohydrates, and proteins) from inorganic raw material by using basic energy sources such as sunlight. Heterotrophs, which include bacteria and fungi, must make use of food that comes from other organisms in the form of fats, carbohydrates, and proteins (U.S. Environmental Protection Agency, 2000; Wetzel, 2001). Higher autotrophic indices occur when heterotrophic bacteria and fungi contribute a larger percentage to the periphyton biomass than the autotrophic algae. The discharge of degradable organic matter to a stream can lead to faster heterotrophic growth than that of the algae, causing a higher autotrophic index, which can be an indicator of organic enrichment of the stream. Streams receiving large levels of organic pollutants (originating from domestic waste, urban runoff, industrial effluent, and farm waste) typically have autotrophic indices greater than 400 (Collins and Weber, 1978). Autotrophic indices of around 250 are more typical for streams enriched with inorganic nutrients that are likely to have existing or potential eutrophication problems (U.S. Environmental Protection Agency, 2000). However, the autotrophic index must be used carefully because non-living detritus (organic matter produced by the decomposition of organisms) in the periphyton may contribute to the AFDM values, thereby inflating the autotrophic index (AFDM:chl- $a$ ratio; U.S Environmental Protection Agency, 2000).

\section{Comparison of Water-Quality Data to Standards and Reference Criteria}

For the continuous water-quality data, conditions were described using the percentage of days during the study period when State standards were exceeded. When calculating the percentage of days with exceedances, any exceedance in the continuous record for a given day was considered as one exceedance. In addition, average daily minimum and maximum values from the continuous water-quality data were calculated and provided to characterize the magnitude of diel fluctuations. Average daily minimum and maximum values were calculated by obtaining the minimum and maximum value for each day for a given month and then taking the average of those values. Daily minimum and maximum values were limited to those days with sufficient data to capture the lowest and highest expected values. 


\section{Groundwater Discharge}

Several methods were applied to delineate and estimate the volumetric flow rate of groundwater discharge to the EFCR in the summers of 2010 and 2012. The methods varied in complexity and in the breadth of information needed for analysis. For example, two relatively simple, qualitative methods included comparing stream and groundwater elevations or stream and groundwater temperatures along multiple transects. More quantitative methods included (1) performing stream seepage runs, (2) applying a chloride mass balance technique, (3) evaluating changes in streamflow specific conductance, and (4) analyzing groundwater flow nets. The comparison of stream stage or temperature to groundwater level or temperature, respectively, was applied only for identifying areas of groundwater discharge in summer 2010; the estimation of groundwater discharge using specific conductance profiles and flow-net analysis was applied in summer 2012 only for identified areas of groundwater discharge. Groundwater discharge was estimated from seepage runs and chloride mass balance in both summer 2010 and summer 2012.

Three well transects that were gaining or losing streamflow were identified by comparing stream stage with groundwater levels in summer 2010. A difference of $0.04 \mathrm{ft}$ or greater between stream stage and groundwater level was the basis for determining if the stream was gaining or losing based on adding the error of the stream-stage measurement $(0.02 \mathrm{ft})$ with the error of the groundwater-level measurement $(0.02 \mathrm{ft})$. If the groundwater levels were at least $0.04 \mathrm{ft}$ greater than the stream stage at a given well transect, then the stream was gaining at that well transect. If the stream stage was at least $0.04 \mathrm{ft}$ greater than the groundwater levels at a given well transect, then the stream was losing at that well transect. If the difference was less than $0.04 \mathrm{ft}$, the stream was considered not strongly gaining or losing. Similarly, differences in temperature between groundwater and the stream at the three well transects were used as an indication of interaction between groundwater and the stream (Stonestrom and Constantz, 2003).

Stream seepage runs were performed in 2010 and 2012 to determine if the stream was gaining or losing between SUT, SMT, and SDT and quantify the net amount of gain or loss. Seepage runs involve a series of streamflow discharge measurements at sites along a stream reach either at the same time or within as short a period as possible during stable streamflow conditions. When there are no tributary inflows or outflows to the stream reach, measureable changes in streamflow rates between two sites identify whether the stream reach has net gains in flow from groundwater discharge to the stream or net stream losses from evapotranspiration or to the underlying aquifer by infiltration (Plume and Smith, 2013). Seepage runs typically are done during low streamflow conditions (Plume and Smith, 2013). The change in streamflow for the study reach was calculated by subtracting the discharge at SUT from the discharge at SMT or SDT. The measurement error associated with the streamflow loss or gain was calculated by using the following propagation of error formula from Wheeler and Eddy-Miller (2005):

$$
s=\left[( \pm a)^{2}+( \pm b)^{2} \ldots+( \pm n)^{2}\right]^{1 / 2}
$$

where

$$
\begin{gathered}
s \quad \begin{array}{c}
\text { is the error propagated from all estimated } \\
\text { individual errors, and } \\
\text { are the estimated errors for the median or } \\
\text { individual stream discharge measurement } \\
\text { at each site. }
\end{array}
\end{gathered}
$$

Several seepage runs were performed along the EFCR between SUT and SDT in 2010 (July 27-29, September 7-8, and October 19-20) and several again in 2012 (July 31, August 30, and September 27). In 2010, stream discharge measurements in July and October were made at all three stream sites over an extended 2-3 day period; however, as a result of changing streamflow conditions from EFCR tributaries and stream diversions located upstream of the study reach, these measurements were not used to calculate seepage losses or gains. For the September 2010 seepage run, stream discharge measurements were made at SUT and SDT over 3-4 hours, and during this period, no tributary surface inflows to or diversions from the main stream reach between SUT and SDT were observed.

Seepage runs in 2012 were completed during the same day and time at SUT, SMT, and SDT. As in 2010, no tributary stream inflows to or diversions from the reach between SUT and SDT were observed during the 2012 seepage runs. Three stream discharge measurements were made sequentially at each stream site during the July seepage run; two stream discharge measurements were made sequentially at each stream site during the seepage runs in August and September. Estimated gains/losses from groundwater were calculated using the median discharge values at SUT, SMT, and SDT. If the estimated net streamflow gain or loss was less than or equal to the associated measurement error, the gain or loss was considered not detected.

The chloride mass balance method was used to estimate the amount of groundwater discharge to the EFCR between SUT and SDT during the summers of 2010 and 2012. The chloride mass balance method is based on the principal of conservation of mass, which states the mass of a closed system must remain constant over time. Moreover, the method assumes no loss of streamflow from evapotranspiration and that chloride concentration generally does not change along groundwater flow paths or in the stream when moving downstream. The load of dissolved chloride was determined as the product of groundwater discharge or stream discharge and associated dissolved chloride concentrations. The volumetric flow rate of groundwater discharge to the study reach was estimated from the difference in dissolved chloride stream loads calculated SUT and SDT divided by the dissolved chloride concentration in discharging groundwater, using an equation similar to the one used by Elliot and others (2006) 
except chloride is used instead of specific conductance. The groundwater discharge was estimated using the following equation:

$$
Q_{g w}=\frac{Q_{S D T} C_{S D T}-Q_{S U T} C_{S U T}}{C_{g w}}
$$

where

$$
\begin{aligned}
& Q_{g w} \quad \text { is groundwater discharge between } S U T \text { and } \\
& \text { SDT in } \mathrm{ft}^{3} / \mathrm{s} \text {; } \\
& Q_{S U T} \text { and } Q_{S D T} \text { are the stream discharges at SUT and SDT } \\
& \text { respectively, in } \mathrm{ft}^{3} / \mathrm{s} \text {; and } \\
& C_{S U T}, C_{S D T} \text {, and } C_{g w} \text { are the dissolved chloride concentrations at } \\
& S U T, S D T \text {, and in groundwater discharging } \\
& \text { to the stream between } S U T \text { and } S D T \text {, } \\
& \text { respectively, in } \mathrm{mg} / \mathrm{L} \text {. }
\end{aligned}
$$

Longitudinal stream profiles of specific conductance were used to indicate areas of groundwater discharge to the EFCR and to estimate relative increase in streamflow along the profile. Areas of groundwater discharge to EFCR were indicated by large increases in specific conductance along the stream profile. If groundwater has higher specific conductance than the stream, and is discharging to the stream, then there will be an increase in specific conductance in the stream moving downstream. During the summer of 2012, specific conductance and temperature measurements were collected along profiles on August 2, 2012, and September 25, 2012 , along the EFCR at about 200- to 500-ft intervals extending from upstream of SUT to downstream of SDT (fig. 6). Specific conductance, temperature, and latitude and longitude readings were taken using a Hydrolab MS5 along with a Surveyor data logger with GPS capabilities. The sonde was cleaned and calibrated per manufacturer's instructions prior to each data-collection event. Relative contribution of groundwater discharge to streamflow was estimated using the specific conductance profile data by applying the same methodology used for chloride mass balance groundwater discharge estimates. Unfortunately, actual stream inflow to the study reach was not measured during these surveys, and so absolute groundwater discharge could not be estimated.

Flow-net analysis was used to quantify groundwater discharge to the EFCR in summer 2012 for a 405-ft reach centered at SMT. A flow net is a graphical representation of two-dimensional steady-state groundwater flow through an aquifer (Rosenberry and LaBaugh, 2008). Flow-net analysis uses the Darcy equation (Rosenberry and LaBaugh, 2008) to solve for discharge, assumes that the aquifer is homogeneous and isotropic, and also assumes that the aquifer effective thickness is saturated and known. The flow net consists of equipotential lines based on the hydraulic head for selected observation wells and the stage of the stream. Flow lines are assumed to be perpendicular to the equipotential lines.
The study subreach was subdivided into two flow nets superimposed on the right bank and bounded by observation wells. The upstream flow net corresponds to groundwater discharge entering the stream between well transect 4 (upper) and well transect 2 (middle-stream) (about $213 \mathrm{ft}$; fig. 6), and the downstream flow net corresponds to discharge between well transect 2 (middle-stream) and well transect 5 (lower) (about 192 ft; fig. 6). Water-level altitude data from pressure transducers and periodic measurements were used to calculate horizontal hydraulic gradients between the water table and the stream. Hydraulic conductivity estimates for use in the Darcy equation were determined using single well aquifer tests (slug tests) for 10 wells completed in the streambed and floodplain that form the shallow aquifer adjacent to the EFCR. Methods used to estimate hydraulic conductivity of the streambed and floodplain sediments and test results are available online (https://nevada.usgs.gov/aquifertests/East_Fork_Carson_ River.cfm?studyname=East_Fork_Carson_River). The slug test data was analyzed using the spreadsheet program of Halford and Kuniansky (2002) based on either the Bouwer and Rice method (1976) or methods presented by Butler and others (2003).

\section{Stream and Groundwater Nutrient Loads}

Stream loads were estimated by multiplying stream nitrate or orthophosphate concentration (in $\mathrm{mg} / \mathrm{L}$ ) by instantaneous discharge (in $\mathrm{ft}^{3} / \mathrm{s}$ ) measured at each stream site (SUT, SMT, SDT). In cases where the concentration was less than the detection limit (at SUT in late September 2012), the concentration at the detection limit was used to estimate stream load. Groundwater loads were estimated for each sampling event by multiplying nitrate or orthophosphate concentration in right bank observation wells by discharge to the EFCR between well transect 4 (upper) and well transect 5 (lower) estimated by flow-net analysis. A unit conversion factor of 5.39 was used to convert estimated steam or groundwater loads to units in pounds per day.

\section{Stream and Groundwater Conditions}

Stream and groundwater conditions were quantified for the study reach and subreach. Stream conditions are summarized by inflows, outflows, and changes in streamflow along the study reach; concentrations and changes in water quality along the reach; and observed algal conditions along the reach. Groundwater conditions are characterized by discharges to the study reach and water-quality concentrations under gaining and losing conditions. 


\section{Discharge}

The physical and biological characteristics observed in the EFCR study reach are controlled, in part, by the magnitude of discharge in the stream and from groundwater discharge to the stream. Stream and groundwater discharge influences water quality and algal conditions in the stream by affecting water temperature, dilution rates, and resulting concentrations of nutrients (Carpenter and others, 2012). Moreover, stream water depth affects the amount of light available for algae to photosynthesize and the areal extent of the algal growth near the streambed (Carpenter and others, 2012). However, in the EFCR during the summer low streamflow conditions, the stream is almost never deep enough that light cannot penetrate to the streambed, unless suspended sediment load is high during or after a storm event or if the amount of periphyton is excessive.

\section{Stream Discharge}

Stream discharge measured at the study reach was relatively low in July and September 2010 and exceptionally low in July through September 2012 relative to historical mean monthly discharges at the discontinued EFCR at Minden stream gaging station (table 6; fig. 4). For example, measured stream discharge in July and September 2010 at all stream sites was less than $18 \mathrm{ft}^{3} / \mathrm{s}$ and less than $8 \mathrm{ft}^{3} / \mathrm{s}$, respectively (table 6). Measured stream discharge in July, August, and September 2012 at all stream sites was less than $5 \mathrm{ft}^{3} / \mathrm{s}$. The historic mean monthly discharges for July, August, and September at the Minden stream gaging station for 14 water years of data were 354,39 , and $12 \mathrm{ft}^{3} / \mathrm{s}$, respectively. Stream discharges measured in October 2010 at all stream sites were between 55 and $70 \mathrm{ft}^{3} / \mathrm{s}$ and above the historical mean monthly discharge of $30 \mathrm{ft}^{3} / \mathrm{s}$ for the Minden stream gaging station. During the 14 water years the Minden stream gaging station operated, the lowest mean monthly discharges for July, August, and September were 0.75, 0.35, and $0.14 \mathrm{ft}^{3} / \mathrm{s}$, respectively. The mean monthly discharge for the Minden stream gaging station was below $6 \mathrm{ft}^{3} / \mathrm{s}$ for 3, 8, and 9 of 14 water years for July, August, and September, respectively.

\section{Groundwater Discharge}

The EFCR study reach gains flow from groundwater during summer low streamflow conditions when algae conditions are most prominent. Results of groundwater discharge analysis to EFCR are summarized here for each of the methods used. The following sections provide (1) evidence and results used to identify gaining and losing reaches and (2) estimates of groundwater discharge using seepage runs, chloride mass balance, specific conductance profiles, and flownet analysis.

\section{Identifying Gaining and Losing Reaches in 2010}

Comparison of stream stage and groundwater-level altitudes during the three sampling events in the summer and fall of 2010 indicate that the stream was both gaining and losing flow (fig. 8). The EFCR was losing flow at well transect 1 (upstream) and along the left bank of well transect 3 (downstream; figs. 8A, $B$ ) and gaining flow at well transect 2 (middle-stream; fig. $8 C$ ) from both banks. However, the vertical hydraulic gradient on the left bank at well transect 2 (middle-stream) was greater than on the right bank (figs. $8 \mathrm{C}$ and 9) and is likely due to infiltration from a nearby agricultural ditch that runs parallel along and near the left bank (fig. 2).

Similar to evidence provided by the water levels, the stream was losing water to the adjacent aquifer at well transect 1 (upstream) and well transect 3 (downstream) (figs. $10 A, 10 B, 11 A$, and $11 B$ ) as evidenced by propagation of diurnal stream temperature fluctuations into the subsurface during late July 2010 (fig. 10) and again in early September (fig. 11). Moreover, at well transect 3 (downstream), the stream appears to be losing more flow along the left bank than along the right bank during late July (fig. 10B). However, stream losses to groundwater at well transect 1 (upstream) and well transect 3 (downstream) in early September appeared to be less than in late July as evidenced by smaller diurnal variations in the groundwater temperature amplitudes. In contrast, the EFCR appears to be gaining flow along well transect 2 (middle-stream) in late July and early September as evidenced by minimal groundwater temperature fluctuations even though the diurnal stream temperature fluctuations were large (figs. 10C and 11C).

Both water levels and water temperature datasets indicate that EFCR is losing at SUT, located near well transect 1 (upstream), and SDT, located near well transect 3 (downstream), and gaining at SMT, located near well transect 2 (middle-stream), during all sample events in 2010. This information was used to focus 2012 investigations of groundwater discharge along the shorter reach centered on SMT and well transect 2 (middle-stream). 
Table 6. Summary of discharge measurements at stream sites and net streamflow gain or loss attributed to groundwater for the 2010 and 2012 studies, East Fork Carson River, Carson Valley, west-central Nevada.

[Site locations are shown in figures 5 and 6. Discharge measurement accuracy: G, good (5 percent of discharge value); F, fair ( 8 percent of discharge value); P, poor (10 percent of discharge value). Abbreviations: $\mathrm{ft}^{3} / \mathrm{s}$, cubic foot per second; $\mathrm{ft}^{3} / \mathrm{s} / \mathrm{mi}$, cubic foot per second per mile; hhmm, hour minute; mm/dd/yyyy, month/day/year; ND, not detected; SDT, East Fork Carson River near Muller Lane downstream transect; SMT, East Fork Carson River near Muller Lane middle-stream transect; SUT, East Fork Carson River near Muller Lane upstream transect; - , not applicable]

\begin{tabular}{|c|c|c|c|c|c|c|c|c|}
\hline \multirow[b]{2}{*}{ Site } & \multicolumn{2}{|c|}{ Measurement } & \multirow{2}{*}{$\begin{array}{c}\text { Discharge } \\
\left(\mathrm{ft}^{3} / \mathrm{s}\right)\end{array}$} & \multirow{2}{*}{$\begin{array}{l}\text { Discharge } \\
\text { measurement } \\
\text { accuracy }^{1}\end{array}$} & \multirow{2}{*}{$\begin{array}{l}\text { Median } \\
\text { discharge } \\
\left(\mathrm{ft}^{3} / \mathrm{s}\right)\end{array}$} & \multirow{2}{*}{$\begin{array}{l}\text { Estimated error of } \\
\text { discharge value }{ }^{1} \\
\qquad\left(\mathrm{ft}^{3} / \mathrm{s}\right)\end{array}$} & \multirow{2}{*}{$\begin{array}{c}\text { Estimated net streamflow } \\
\text { gain }(+) \text { or loss }(-) \text { with } \\
\text { associated measurement error }{ }^{2} \\
\left(\mathrm{ft}^{3} / \mathbf{s}\right)\end{array}$} & \multirow{2}{*}{$\begin{array}{c}\text { Estimated groundwater } \\
\text { discharge (+) or } \\
\text { streamflow loss (-) } \\
\left(\mathrm{ft}^{3} / \mathrm{s} / \mathrm{mi}\right)\end{array}$} \\
\hline & $\begin{array}{c}\text { Date } \\
\text { (mm/dd/yyyy) }\end{array}$ & $\begin{array}{l}\text { Time interval } \\
\text { (hhmm-hhmm) }\end{array}$ & & & & & & \\
\hline \multicolumn{9}{|c|}{ Late July $2010^{3}$} \\
\hline SUT & $07 / 29 / 2010$ & $1221-1256$ & 17.7 & G & - & \pm 0.9 & - & - \\
\hline SMT & 07/28/2010 & 0920-1005 & 15.7 & $\mathrm{P}$ & - & \pm 1.6 & - & - \\
\hline SDT & $07 / 27 / 2010$ & $1342-1427$ & 14.8 & $\mathrm{~F}$ & - & \pm 1.2 & - & - \\
\hline \multicolumn{9}{|c|}{ Early September 2010} \\
\hline SUT & 09/07/2010 & $1249-1331$ & 5.69 & $\mathrm{~F}$ & - & \pm 0.5 & - & - \\
\hline SMT & 09/08/2010 & $1004-1052$ & 6.58 & $\mathrm{~F}$ & - & \pm 0.5 & - & - \\
\hline SDT & 09/07/2010 & 0954-1043 & 7.72 & $\mathrm{~F}$ & - & \pm 0.6 & - & - \\
\hline SUT-SMT $^{3}$ & - & - & - & - & - & - & - & - \\
\hline SMT-SDT $^{3}$ & - & - & - & - & - & - & - & - \\
\hline SUT-SDT & - & - & - & - & - & - & (+) $2.0 \pm 0.8$ & $(+) 1.8$ \\
\hline \multicolumn{9}{|c|}{ Mid October $2010^{3}$} \\
\hline SUT & $10 / 20 / 2010$ & $1302-1344$ & 55 & $\mathrm{~F}$ & - & \pm 4.4 & - & - \\
\hline SMT & $10 / 19 / 2010$ & $1250-1330$ & 70 & $\mathrm{~F}$ & - & \pm 5.6 & - & - \\
\hline SDT & $10 / 19 / 2010$ & 0949-1027 & 68 & $\mathrm{~F}$ & - & \pm 5.4 & - & - \\
\hline \multicolumn{9}{|c|}{ Late July 2012} \\
\hline SUT & $07 / 31 / 2012$ & $1248-1340$ & 2.36 & $\mathrm{~F}$ & - & - & - & - \\
\hline SUT & $07 / 31 / 2012$ & $1351-1429$ & 2.22 & $\mathrm{~F}$ & 2.26 & \pm 0.2 & - & - \\
\hline SUT & $07 / 31 / 2012$ & $1437-1519$ & 2.26 & $\mathrm{~F}$ & - & - & - & - \\
\hline SMT & 07/31/2012 & $1238-1313$ & 4.07 & $\mathrm{~F}$ & - & - & - & - \\
\hline SMT & 07/31/2012 & $1324-1357$ & 3.66 & $\mathrm{~F}$ & 3.66 & \pm 0.3 & - & - \\
\hline SMT & $07 / 31 / 2012$ & $1410-1441$ & 3.26 & $\mathrm{~F}$ & - & - & - & - \\
\hline SUT-SMT & - & - & - & - & - & - & (+) $1.4 \pm 0.4$ & $(+) 2.6$ \\
\hline SDT & $07 / 31 / 2012$ & $1239-1322$ & 2.82 & $\mathrm{~F}$ & - & - & - & - \\
\hline SDT & $07 / 31 / 2012$ & $1330-1406$ & 2.50 & $\mathrm{~F}$ & 2.50 & \pm 0.2 & - & - \\
\hline SDT & 07/31/2012 & $1415-1448$ & 2.48 & $\mathrm{~F}$ & - & - & - & - \\
\hline SMT-SDT & - & - & - & - & - & - & $(-) 1.2 \pm 0.4$ & (-) 2.2 \\
\hline SUT-SDT & - & - & - & - & - & - & (+) $0.24 \pm 0.3$ & ND \\
\hline
\end{tabular}


Table 6. Summary of discharge measurements at stream sites and net streamflow gain or loss attributed to groundwater for the 2010 and 2012 studies, East Fork Carson River, Carson Valley, west-central Nevada.-Continued

[Site locations are shown in figures 5 and 6. Discharge measurement accuracy: G, good ( 5 percent of discharge value); F, fair ( 8 percent of discharge value); P, poor (10 percent of discharge value). Abbreviations: $\mathrm{ft}^{3} / \mathrm{s}$, cubic foot per second; $\mathrm{ft}^{3} / \mathrm{s} / \mathrm{mi}$, cubic foot per second per mile; hhmm, hour minute; mm/dd/yyyy, month/day/year; ND, not detected; SDT, East Fork Carson River near Muller Lane downstream transect; SMT, East Fork Carson River near Muller Lane middle-stream transect; SUT, East Fork Carson River near Muller Lane upstream transect; —, not applicable]

\begin{tabular}{|c|c|c|c|c|c|c|c|c|}
\hline \multirow[b]{2}{*}{ Site } & \multicolumn{2}{|c|}{ Measurement } & \multirow[b]{2}{*}{$\begin{array}{c}\text { Discharge } \\
\left(\mathrm{ft}^{3} / \mathrm{s}\right)\end{array}$} & \multirow{2}{*}{$\begin{array}{l}\text { Discharge } \\
\text { measurement } \\
\text { accuracy }^{1}\end{array}$} & \multirow{2}{*}{$\begin{array}{l}\text { Median } \\
\text { discharge } \\
\left(\mathrm{ft}^{3} / \mathbf{s}\right)\end{array}$} & \multirow{2}{*}{$\begin{array}{l}\text { Estimated error of } \\
\text { discharge value }{ }^{1} \\
\qquad\left(\mathrm{ft}^{3} / \mathrm{s}\right)\end{array}$} & \multirow{2}{*}{$\begin{array}{c}\text { Estimated net streamflow } \\
\text { gain }(+) \text { or loss }(-) \text { with } \\
\text { associated measurement error }{ }^{2} \\
\left(\mathrm{ft}^{3} / \mathrm{s}\right)\end{array}$} & \multirow{2}{*}{$\begin{array}{c}\text { Estimated groundwater } \\
\text { discharge (+) or } \\
\text { streamflow loss (-) } \\
\left(\mathrm{ft}^{3} / \mathrm{s} / \mathrm{mi}\right)\end{array}$} \\
\hline & $\begin{array}{c}\text { Date } \\
\text { (mm/dd/yyyy) }\end{array}$ & $\begin{array}{c}\text { Time interval } \\
\text { (hhmm-hhmm) }\end{array}$ & & & & & & \\
\hline \multicolumn{9}{|c|}{ Late August 2012} \\
\hline SUT & $08 / 30 / 2012$ & $1357-1434$ & 2.31 & $\mathrm{~F}$ & 2.25 & \pm 0.2 & - & - \\
\hline SUT & 08/30/2012 & $1446-1521$ & 2.19 & $\mathrm{~F}$ & - & - & - & - \\
\hline SMT & $08 / 30 / 2012$ & $1334-1421$ & 3.32 & $\mathrm{G}$ & 3.08 & \pm 0.2 & - & - \\
\hline SMT & 08/30/2012 & $1427-1456$ & 2.85 & $\mathrm{~F}$ & - & - & - & - \\
\hline SUT-SMT & - & - & - & - & - & - & (+) $0.83 \pm 0.3$ & (+) 1.5 \\
\hline SDT & 08/30/2012 & $1332-1417$ & 3.17 & $\mathrm{~F}$ & 2.88 & \pm 0.3 & - & - \\
\hline SDT & $08 / 30 / 2012$ & $1429-1512$ & 2.59 & $\mathrm{P}$ & - & - & - & - \\
\hline SMT-SDT & - & - & - & - & - & - & (-) $0.20 \pm 0.4$ & ND \\
\hline SUT-SDT & - & - & - & - & - & - & $(+) 0.63 \pm 0.4$ & $(+) 0.58$ \\
\hline \multicolumn{9}{|c|}{ Late September 2012} \\
\hline SUT & 09/27/2012 & $1010-1052$ & 1.65 & G & 1.66 & \pm 0.1 & - & - \\
\hline SUT & 09/27/2012 & $1101-1141$ & 1.66 & G & - & - & - & - \\
\hline SMT & 09/27/2012 & 1029-1055 & 2.75 & $\mathrm{~F}$ & 2.70 & \pm 0.2 & - & - \\
\hline SMT & 09/27/2012 & $1113-1141$ & 2.66 & $\mathrm{~F}$ & - & - & - & - \\
\hline SUT-SMT & - & - & - & - & - & - & (+) $1.0 \pm 0.2$ & $(+) 1.8$ \\
\hline SDT & 09/27/2012 & $1027-1058$ & 2.92 & $\mathrm{~F}$ & 3.00 & \pm 0.2 & - & - \\
\hline SDT & 09/27/2012 & $1105-1138$ & 3.07 & $\mathrm{~F}$ & - & - & - & - \\
\hline SMT-SDT & - & - & - & - & - & - & (+) $0.30 \pm 0.3$ & ND \\
\hline SUT-SDT & - & - & - & - & - & - & $(+) 1.3 \pm 0.2$ & $(+) 1.2$ \\
\hline
\end{tabular}

${ }^{1}$ For good accuracy used 5 percent of discharge value, fair accuracy used 8 percent of discharge value, poor accuracy used 10 percent of discharge value.

${ }^{2}$ Measurement error was calculated using the following propagation of error formula: $s=\left[( \pm a)^{2}+( \pm b)^{2} \ldots+( \pm n)^{2}\right]^{1 / 2}$, where $s$ is the error propagated from all estimated individual errors and $a, b, \ldots, n$ are the estimated errors for the median or individual discharge measurement at each site.

${ }^{3}$ Estimated streamflow gain or loss was not calculated because discharge measurements at sites were not made on the same day. 
$\boldsymbol{A}$

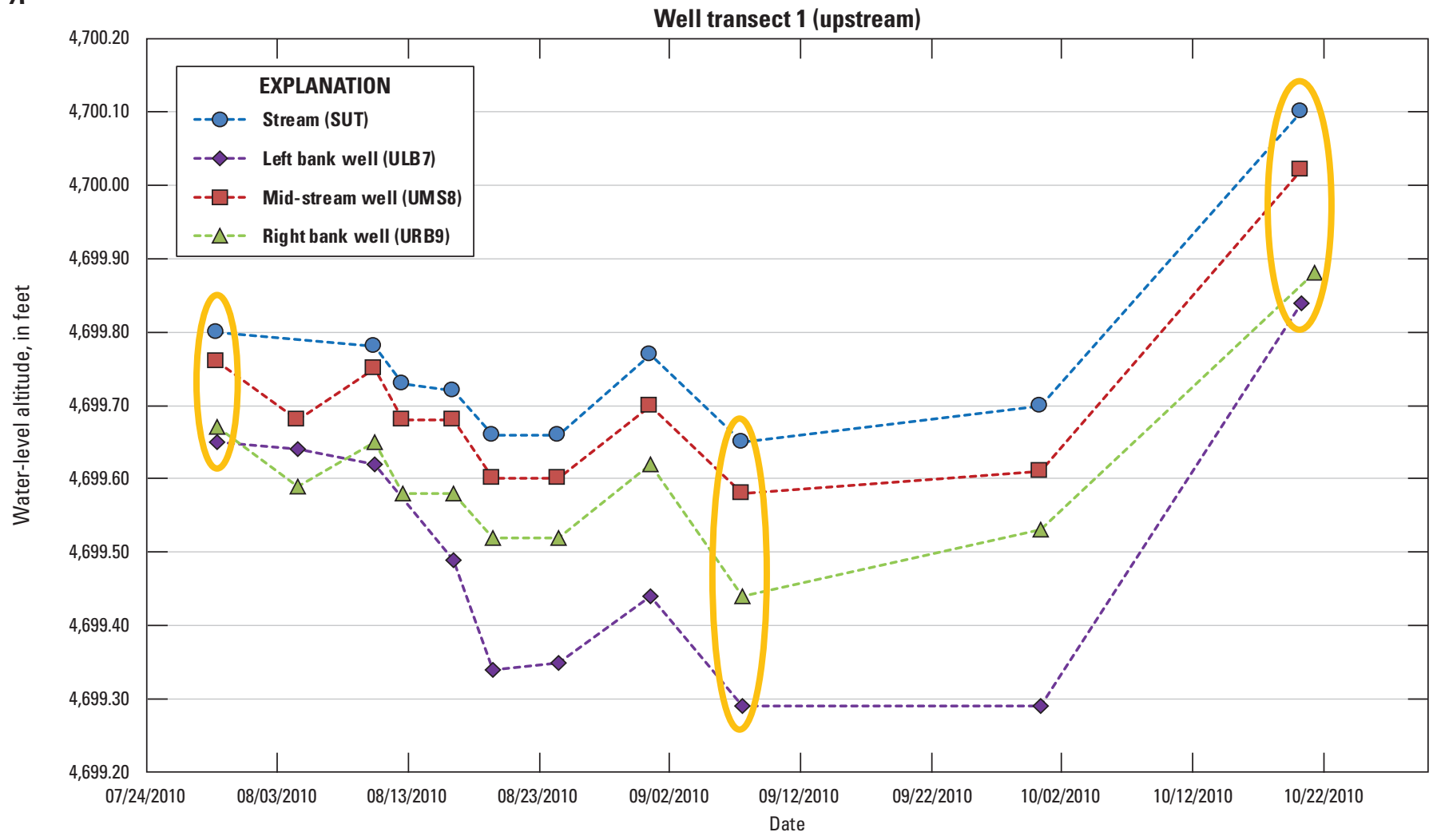

$B$

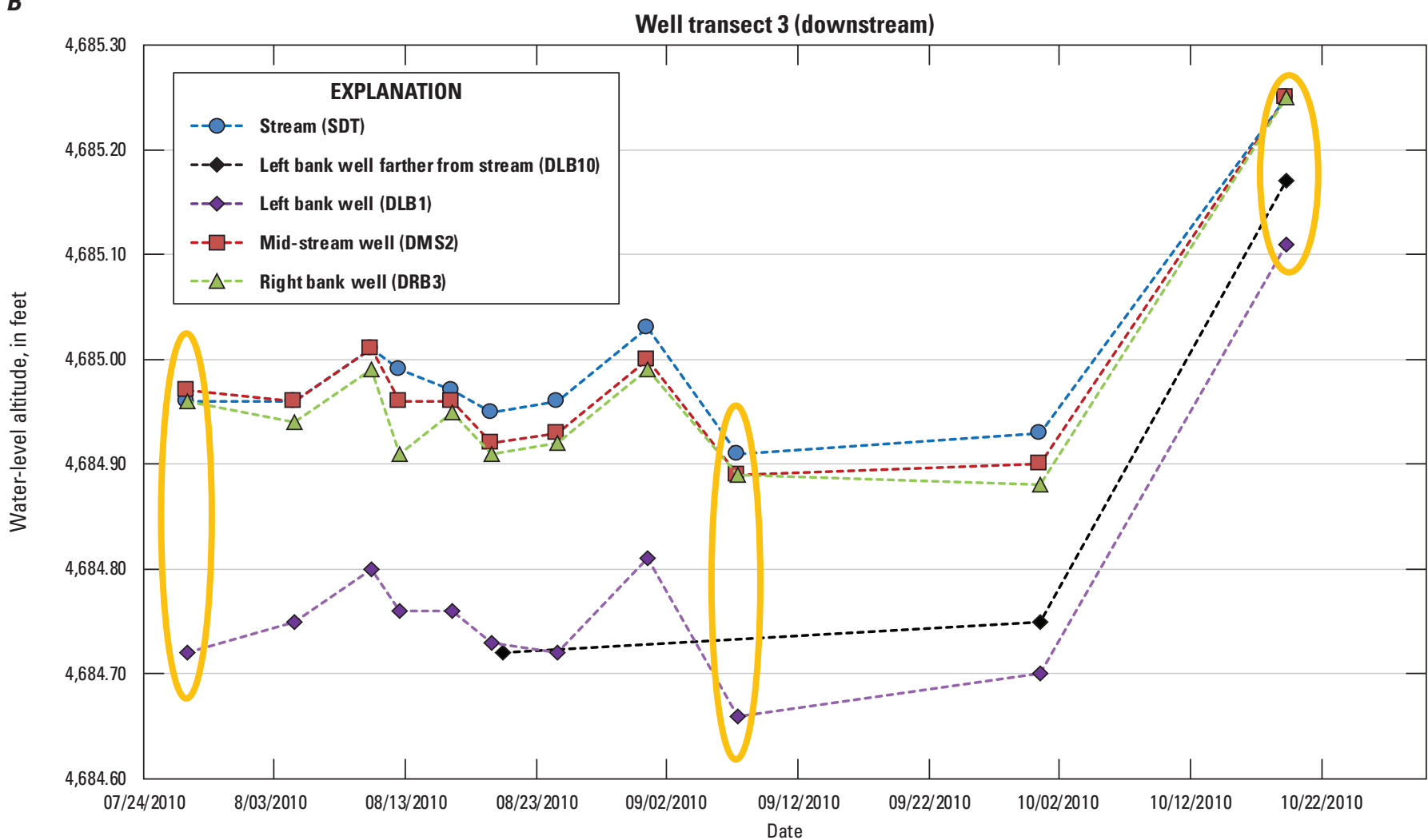

Figure 8. Water-level altitudes in observation wells and the stream at well transects, summer 2010, East Fork Carson River, Carson Valley, west-central Nevada. $A$, well transect 1 (upstream); $B$, well transect 3 (downstream); and $C$, well transect 2 (middle-stream). Stream sites are East Fork Carson River near Muller Lane upstream transect (SUT), East Fork Carson River near Muller Lane middlestream transect (SMT), and East Fork Carson River near Muller Lane downstream transect (SDT). The ellipses indicate when waterquality sampling occurred in 2010. 
C

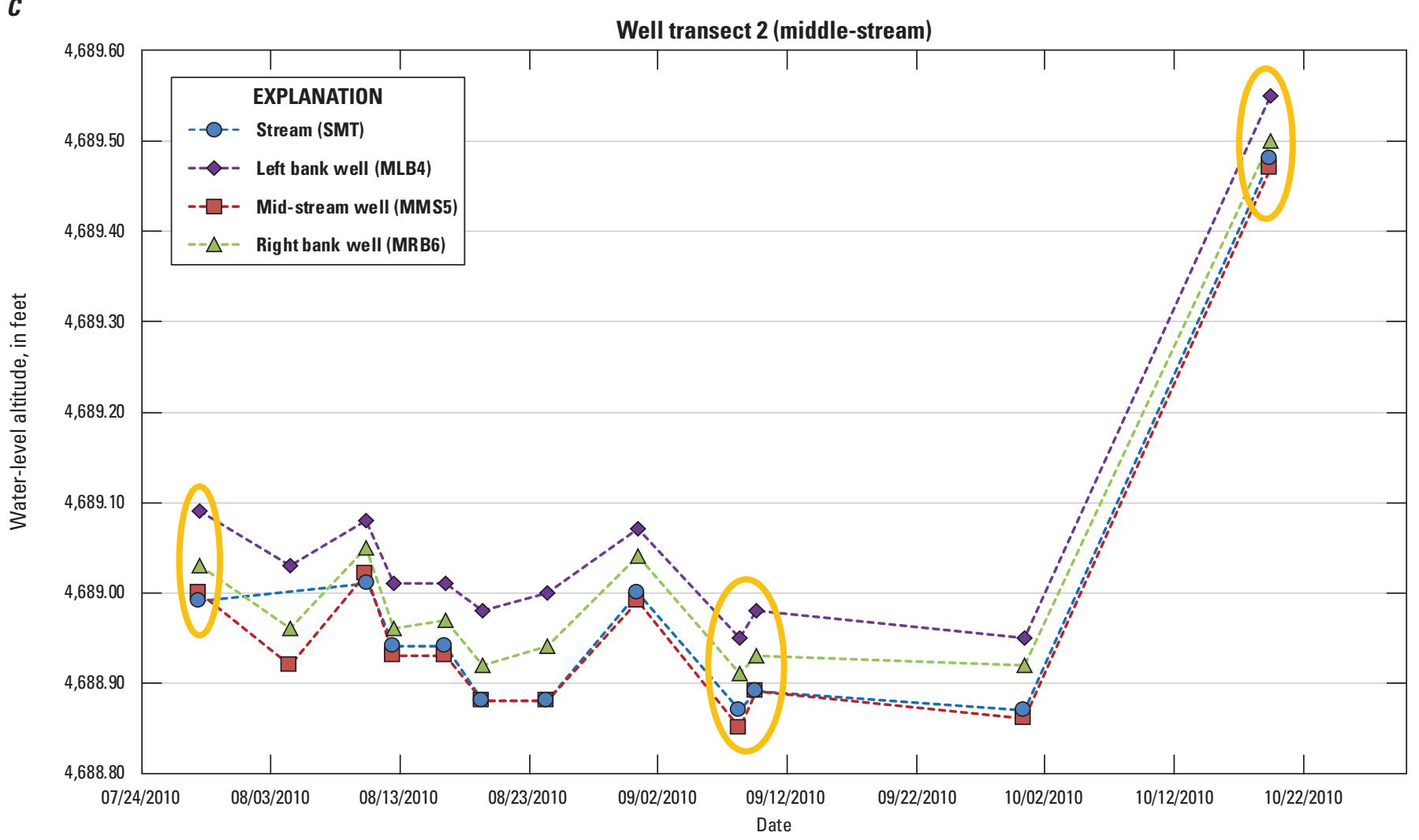

Figure 8. - Continued

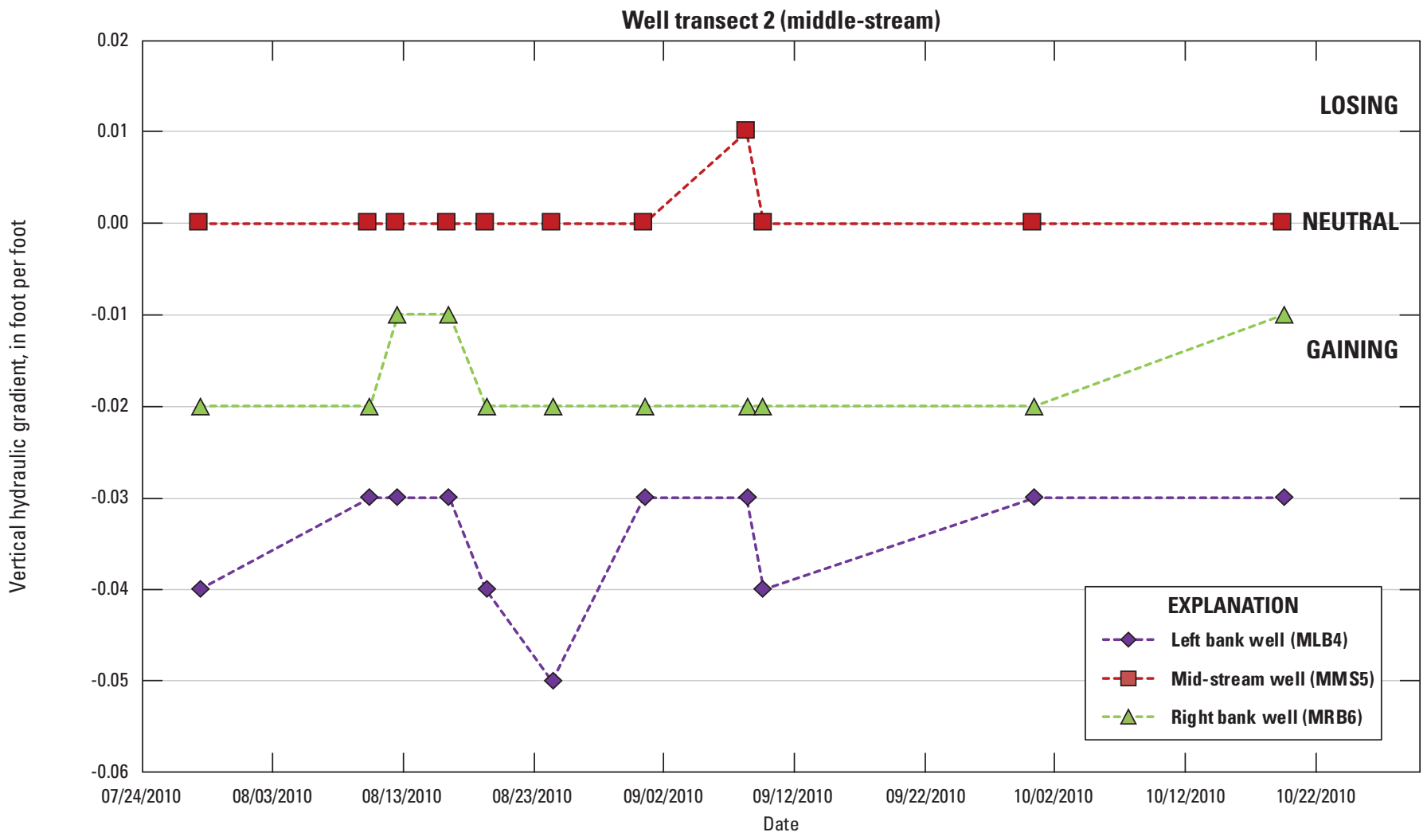

Figure 9. Vertical hydraulic gradients between streambank wells and stream and between mid-stream well and stream at well transect 2 (middle-stream), summer 2010, East Fork Carson River, Carson Valley, west-central Nevada. Losing means the stream is losing water to groundwater, gaining means the stream is gaining water from groundwater, and neutral means the stream is neither gaining nor losing water. 
$\boldsymbol{A}$

Well transect 1 (upstream)

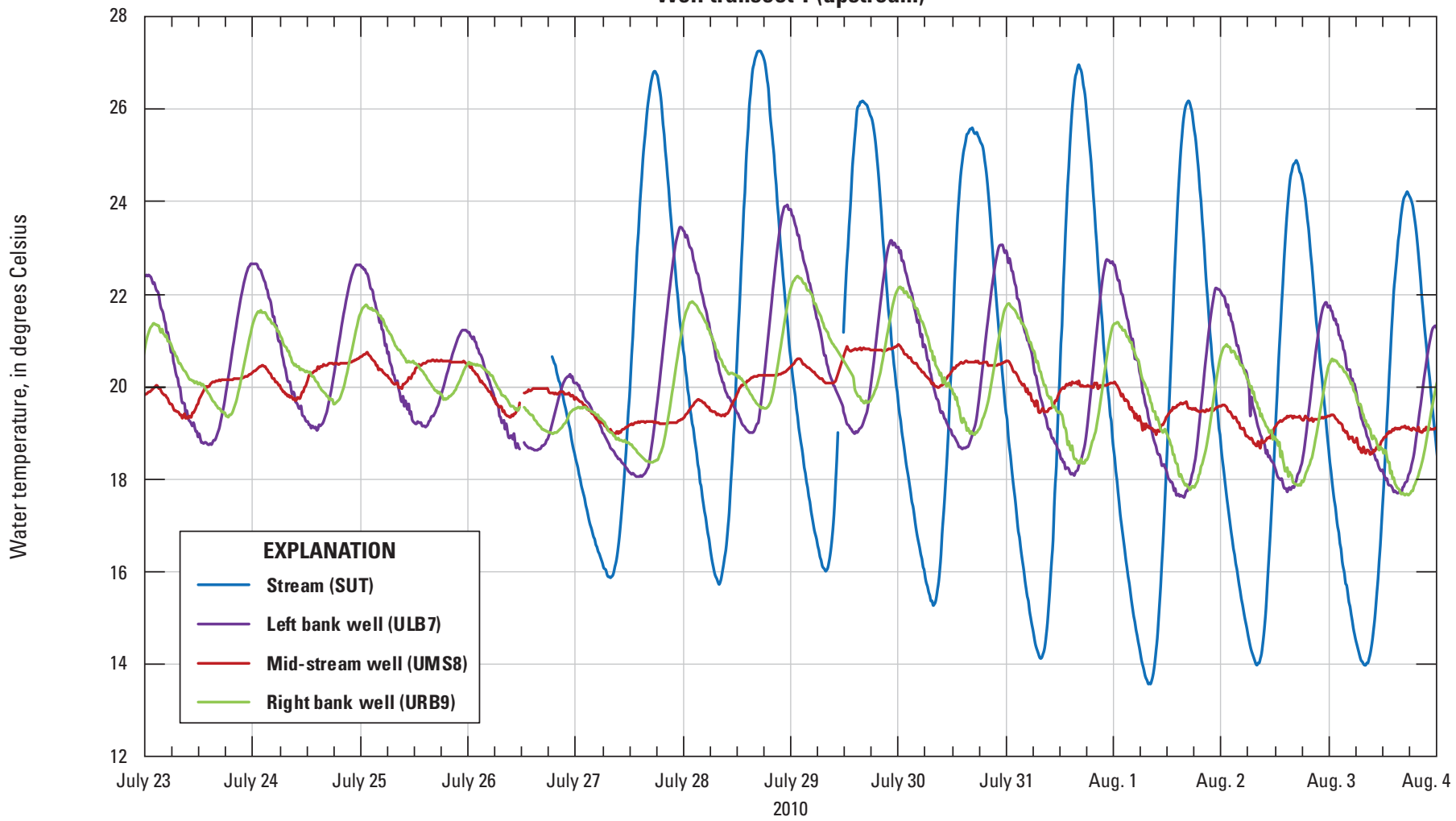

$B$

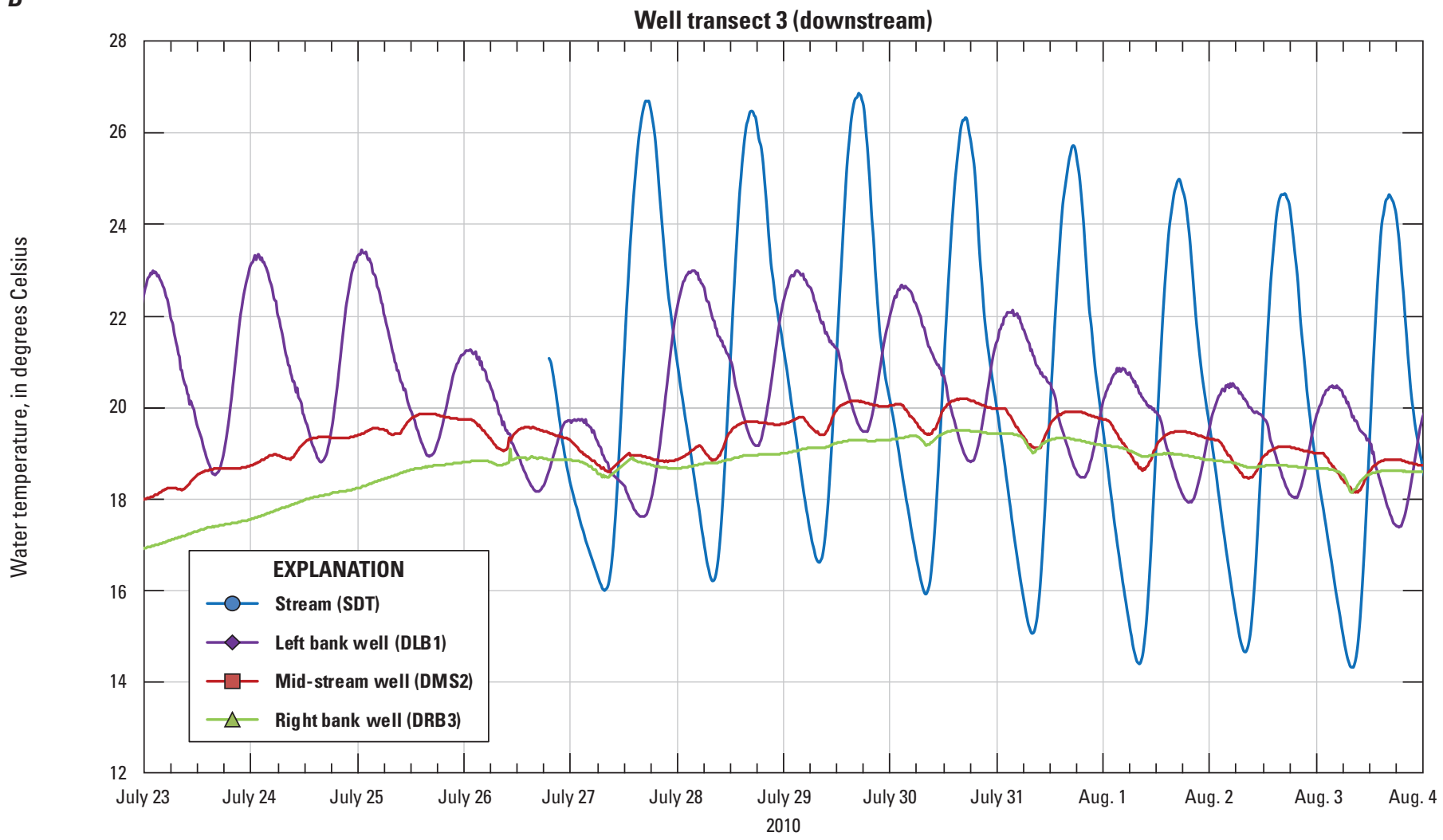

Figure 10. Water temperature at well transects and stream sites of the East Fork Carson River, Carson Valley, west-central Nevada, July and August 2010. A, well transect 1 (upstream); B, well transect 3 (downstream); and $C$, well transect 2 (middle-stream). Stream sites are East Fork Carson River near Muller Lane upstream transect (SUT), East Fork Carson River near Muller Lane middle-stream transect (SMT), and East Fork Carson River near Muller Lane downstream transect (SDT). 
c

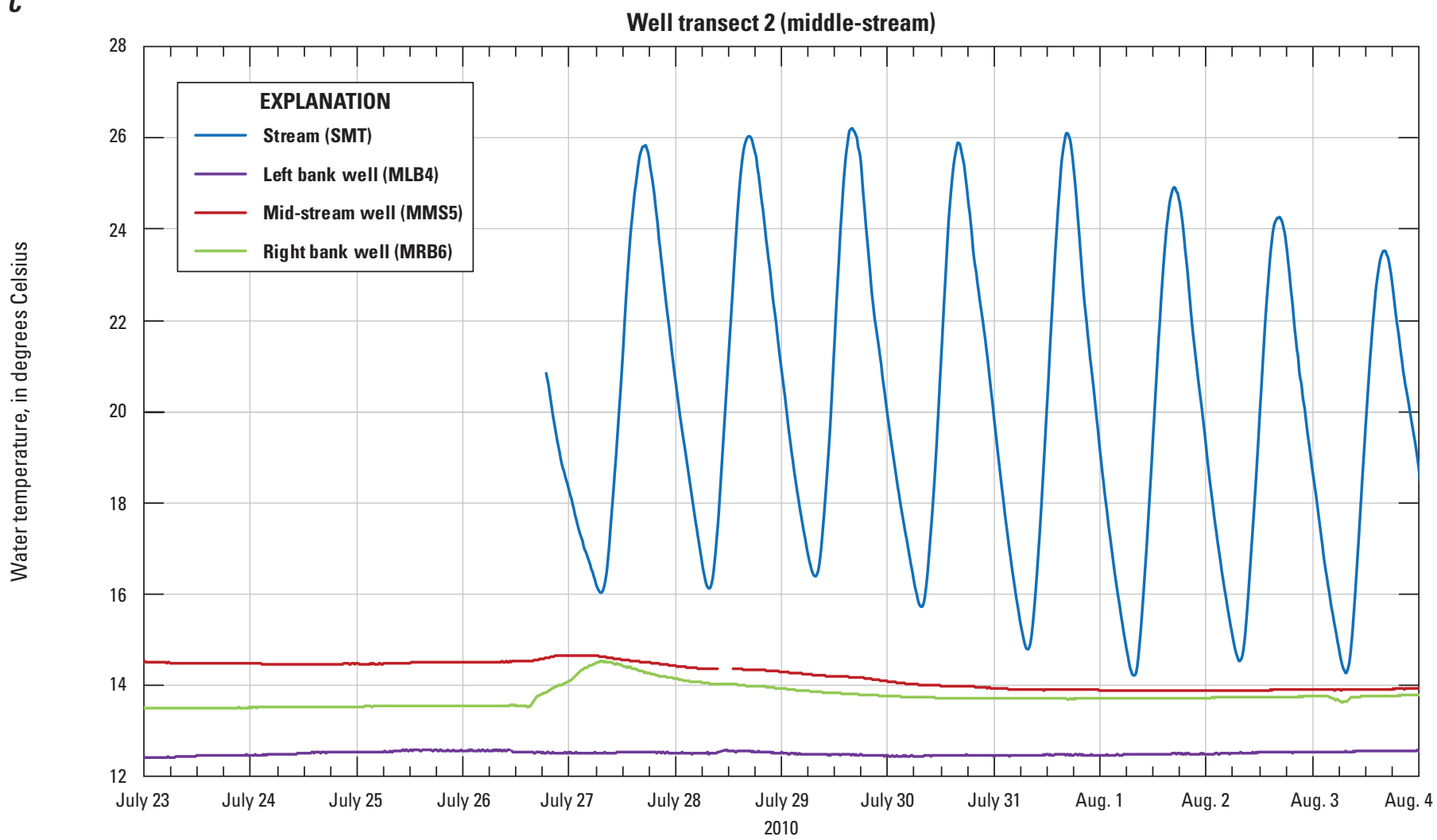

Figure 10. - Continued 
$\boldsymbol{A}$

Well transect 1 (upstream)

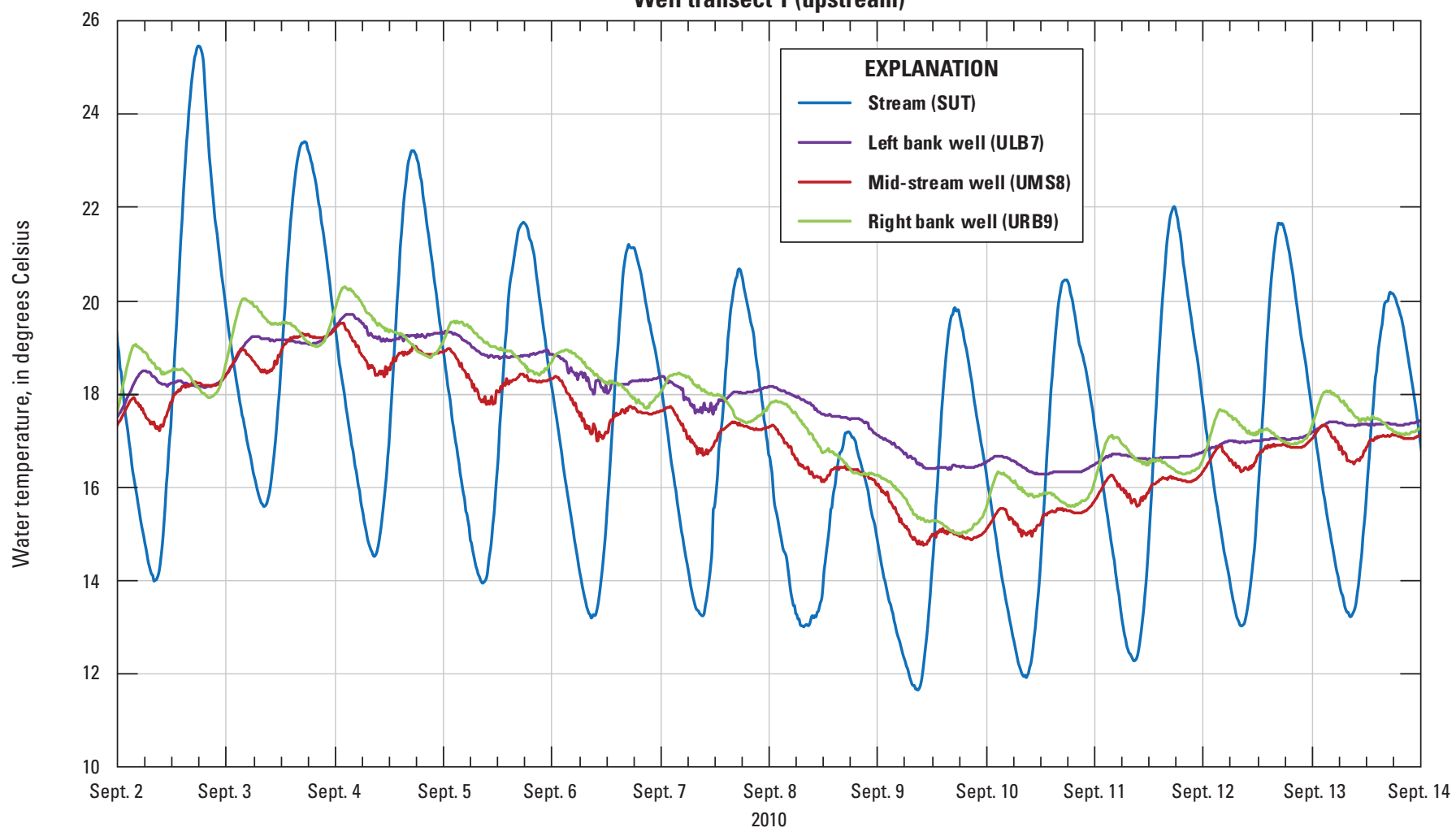

B

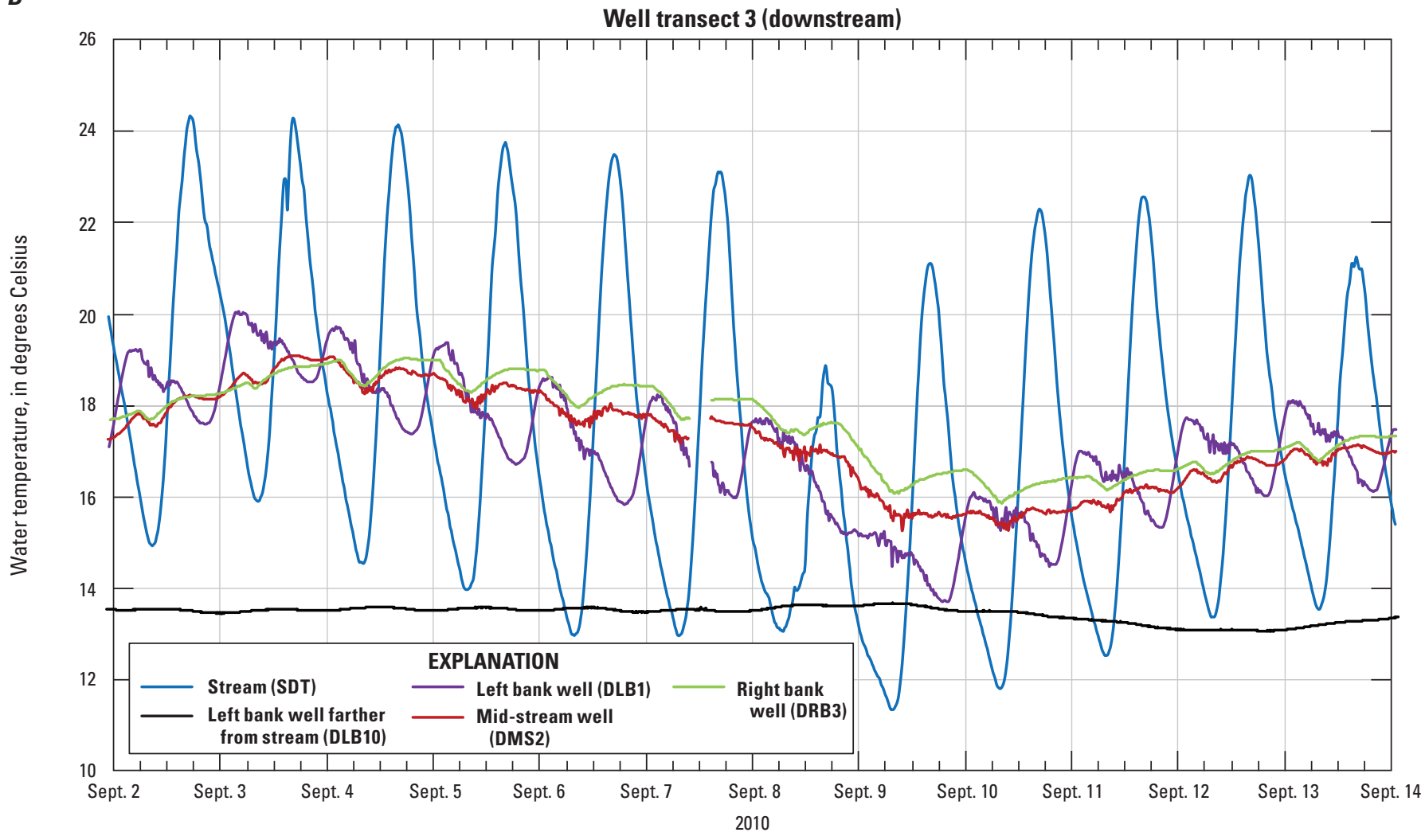

Figure 11. Water temperature at well transects and stream sites of the East Fork Carson River, Carson Valley, west-central Nevada, September 2010. $A$, well transect 1 (upstream); $B$, well transect 3 (downstream); and $C$, well transect 2 (middle-stream). Stream sites are East Fork Carson River near Muller Lane upstream transect (SUT), East Fork Carson River near Muller Lane middle-stream transect (SMT), and East Fork Carson River near Muller Lane downstream transect (SDT). 
C

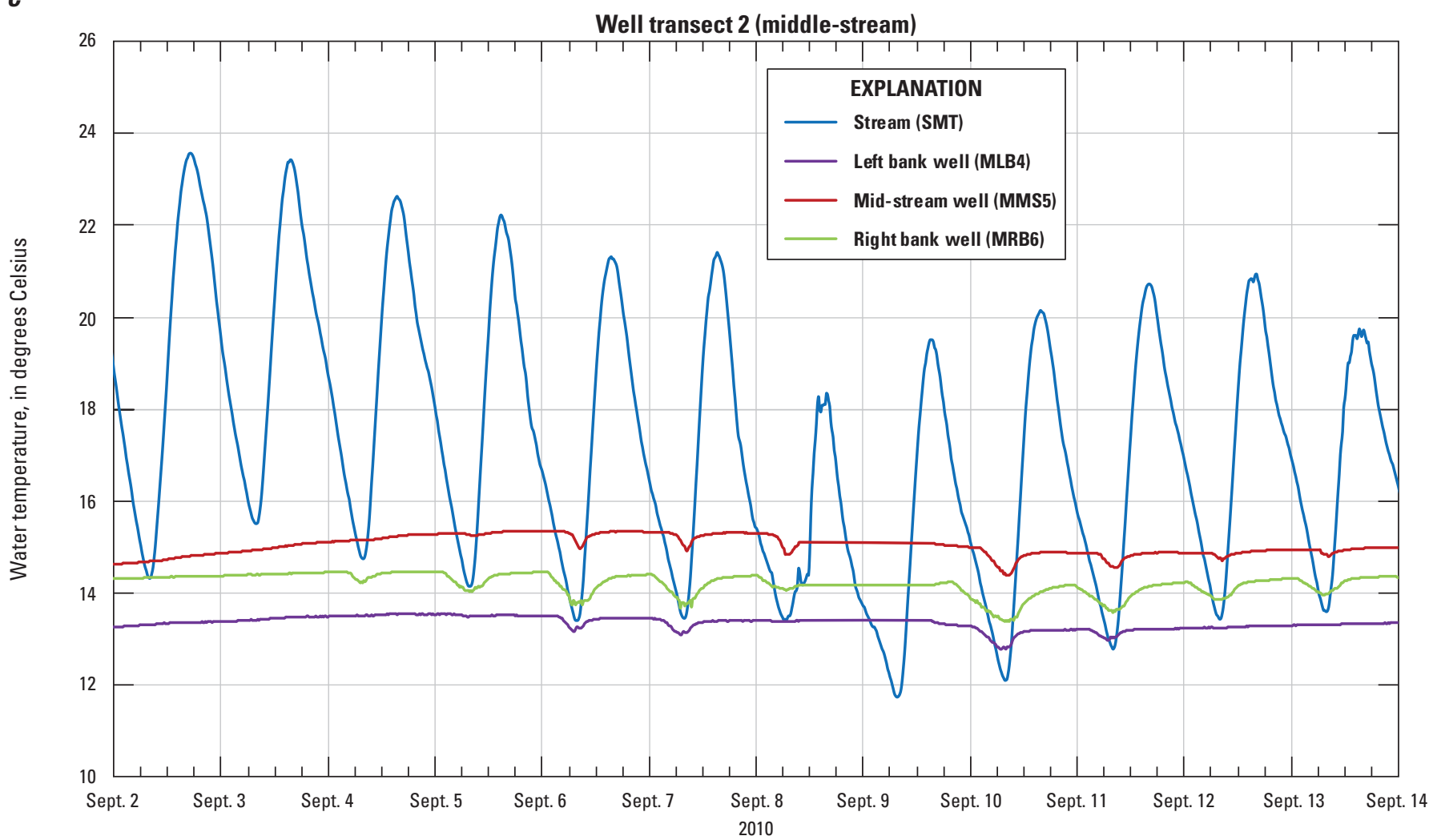

Figure 11. -Continued

\section{Stream Seepage Runs}

Seepage run results indicate net gains from groundwater along the entire 5,765-ft EFCR reach between SUT and SDT during the two summer investigations (table 6); however, closer inspection indicates the majority of groundwater inflow is occurring along the upper reach between SUT and SMT. In September 2010, the EFCR had a net gain of $2.0 \mathrm{ft}^{3} / \mathrm{s}$ (or 1.8 cubic feet per second per mile, $\mathrm{ft}^{3} / \mathrm{s} / \mathrm{mi}$ ) between SUT and SDT, and during the summer of 2012, the net gains ranged between not detected to $1.3 \mathrm{ft}^{3} / \mathrm{s}\left(\right.$ or $\left.1.2 \mathrm{ft}^{3} / \mathrm{s} / \mathrm{mi}\right)$. The net gains from groundwater inflow were obvious: streamflow along the reach increased by about 35 percent in September 2010, and the observable gains were 28- and 78-percent increase in streamflow during late August and September 2012, respectively.

A more detailed analysis of 2012 seepage run data indicates most of the groundwater discharge to the EFCR study reach was occurring along the upper reach between SUT and SMT (table 6). The 2,897-ft upper reach had net gains of 0.83 and $1.4 \mathrm{ft}^{3} / \mathrm{s}$ (or 1.5 to $2.6 \mathrm{ft}^{3} / \mathrm{s} / \mathrm{mi}$ ), which were equivalent to 37- and 62-percent increases in streamflow along the upper reach. The 2,868-ft lower reach between SMT and SDT had no observable gains and actually had a net loss during the July 2012 seepage run. The net loss for the lower reach on July 31,2012 , was $1.2 \mathrm{ft}^{3} / \mathrm{s}$ (or $-2.2 \mathrm{ft}^{3} / \mathrm{s} / \mathrm{mi}$ ), equivalent to a 33 -percent reduction in streamflow.

\section{Chloride Mass Balance}

Dissolved chloride concentration and stream discharge data and a mass balance analysis were used as an alternative method for estimating groundwater discharge to the EFCR between SUT and SDT in September 2010, early August 2012, late August 2012, and September 2012 (table 7). For 2010, the average dissolved chloride concentration in groundwater was determined using well transect 2 (middle-stream) right bank (MRB6) and left bank (MLB4) wells. For 2012, the average dissolved chloride concentration in groundwater was determined using the right bank wells at well transect 4 (upper), well transect 2 (middle-stream), and well transect 5 (lower; fig. 6).

Stream dissolved chloride concentrations in September 2010 increased from $4.33 \mathrm{mg} / \mathrm{L}$ at SUT to $6.19 \mathrm{mg} / \mathrm{L}$ at SDT (table 7), and streamflow increased from 5.7 to $7.7 \mathrm{ft}^{3} / \mathrm{s}$. Using an average dissolved chloride concentration in groundwater of $7.32 \mathrm{mg} / \mathrm{L}$, the estimated groundwater discharge entering EFCR between SUT and SDT (equation 4) was $3.16 \mathrm{ft}^{3} / \mathrm{s}$, and when normalized for the distance between SUT and SDT $(5,765 \mathrm{ft})$, was $2.90 \mathrm{ft}^{3} / \mathrm{s} / \mathrm{mi}$.

Using this same approach for the three sampling events in 2012, total estimated gains from groundwater between SUT and SDT were $0.5,0.6$, and $0.9 \mathrm{ft}^{3} / \mathrm{s}$ in early August, late August, and late September, respectively (table 7). These are the equivalent to normalized gains of $0.5,0.5$, and $0.8 \mathrm{ft}^{3} / \mathrm{s} / \mathrm{mi}$, respectively. 
Table 7. Streamflow, chloride concentration, and estimated groundwater discharge based on the chloride mass balance method, 2010 and 2012, East Fork Carson River, Carson Valley, west-central Nevada.

[Aug., August; $\mathrm{ft}^{3} / \mathrm{s}$, cubic foot per second; mg/L, milligram per liter; SDT, East Fork Carson River near Muller Lane downstream transect; Sept., September; SUT, East Fork Carson River near Muller Lane upstream transect]

\begin{tabular}{|c|c|c|c|c|c|c|c|c|c|c|c|c|c|c|c|c|}
\hline \multirow{2}{*}{$\begin{array}{c}\text { Location } \\
\text { (figs. } 5 \text { and } 6 \text { ) }\end{array}$} & \multicolumn{4}{|c|}{$\begin{array}{c}\text { Stream discharge } \\
\left(\mathrm{ft}^{3} / \mathrm{s}\right)\end{array}$} & \multicolumn{4}{|c|}{$\begin{array}{l}\text { Chloride concentration } \\
\text { (mg/L) }\end{array}$} & \multicolumn{4}{|c|}{$\begin{array}{c}\text { Groundwater discharge } \\
\left(\mathrm{ft}^{3} / \mathrm{s}\right)\end{array}$} & \multicolumn{4}{|c|}{$\begin{array}{c}\text { Groundwater discharge } \\
\left(\mathrm{ft}^{3} / \mathrm{s} \text { per mile) }\right.\end{array}$} \\
\hline & $\begin{array}{l}\text { Early } \\
\text { Sept. } \\
2010\end{array}$ & $\begin{array}{c}1,2 \text { Early } \\
\text { Aug. } \\
2012\end{array}$ & $\begin{array}{l}\text { 'Late } \\
\text { Aug. } \\
2012\end{array}$ & $\begin{array}{l}\text { 'Late } \\
\text { Sept. } \\
2012\end{array}$ & $\begin{array}{l}\text { Early } \\
\text { Sept. } \\
2010\end{array}$ & $\begin{array}{c}{ }^{2} \text { Early } \\
\text { Aug. } \\
2012\end{array}$ & $\begin{array}{l}\text { Late } \\
\text { Aug. } \\
2012\end{array}$ & $\begin{array}{l}\text { Late } \\
\text { Sept. } \\
2012\end{array}$ & $\begin{array}{l}\text { Early } \\
\text { Sept. } \\
2010\end{array}$ & $\begin{array}{c}{ }^{2} \text { Early } \\
\text { Aug. } \\
2012\end{array}$ & $\begin{array}{l}\text { Late } \\
\text { Aug. } \\
2012\end{array}$ & $\begin{array}{l}\text { Late } \\
\text { Sept. } \\
2012\end{array}$ & $\begin{array}{l}\text { Early } \\
\text { Sept. } \\
2010\end{array}$ & $\begin{array}{c}{ }^{2} \text { Early } \\
\text { Aug. } \\
2012\end{array}$ & $\begin{array}{l}\text { Late } \\
\text { Aug. } \\
2012\end{array}$ & $\begin{array}{l}\text { Late } \\
\text { Sept. } \\
2012\end{array}$ \\
\hline SUT & 5.69 & 2.26 & 2.25 & 1.66 & 4.33 & 4.23 & 6.40 & 9.41 & - & - & - & - & - & - & - & - \\
\hline $\begin{array}{l}\text { Observation } \\
\text { wells }^{3,4}\end{array}$ & - & - & - & - & 7.32 & 15.79 & 17.26 & 17.36 & - & - & - & - & - & - & - & - \\
\hline SDT & 7.72 & 2.50 & 2.88 & 3.00 & 6.19 & 7.17 & 8.55 & 10.60 & 3.16 & 0.53 & 0.59 & 0.93 & 2.90 & 0.49 & 0.54 & 0.85 \\
\hline
\end{tabular}

${ }^{1}$ Stream discharge is the median of 2-3 measurements.

${ }^{2}$ Stream discharge and stream chloride concentrations at SUT and SDT were measured in late July 2012. Groundwater chloride concentration measured in early August 2012.

${ }^{3}$ Early Sept. 2010 chloride concentration in groundwater is the average concentration from the left bank and right bank observation wells at well transect 2 (middle-stream; fig. 5).

${ }^{4} 2012$ chloride concentration in groundwater is the average concentration from the right bank wells at well transect 4 (upper), well transect 2 (middle-stream), and well transect 5 (lower; fig. 6).

\section{Specific Conductance Profiles}

Assuming that specific conductance along the stream reach remains constant (Elliot and others, 2006) and all increases are a result of higher specific conductance groundwater discharge to the reach, then the proportion of flow originating from groundwater discharge along the reach can be estimated. The method used here is analogous to estimating groundwater discharge using the chloride mass balance technique discussed earlier, except specific conductance is used instead of chloride concentration.

Specific conductance in EFCR increased substantially from about 250 microsiemens per centimeter at 25 degrees Celsius $\left(\mu \mathrm{S} / \mathrm{cm}\right.$ at $\left.25^{\circ} \mathrm{C}\right)$ upstream of the study reach to more than $350 \mu \mathrm{S} / \mathrm{cm}$ downstream of the study reach in August 2012 and to more than $400 \mu \mathrm{S} / \mathrm{cm}$ downstream of SDT in late September 2012 (fig. 12). In contrast, average specific conductance of groundwater inflow to EFCR ranged between 530 and $558 \mu \mathrm{S} / \mathrm{cm}$ during this period, which is roughly twice that of the stream specific conductance entering the study reach at SUT. Discharge of groundwater to the stream between SUT and SDT is almost certainly the cause of the observed increase in specific conductance.

Because streamflow discharge was not measured during the specific conductance profile data collection, only the relative proportion of groundwater discharge to the reach was estimated (fig. 13). Specific conductance data collected along the two longitudinal stream profile measurements shown in figure 12 indicate substantial contribution of groundwater to the reach beginning at about 0.8 miles (mi) downstream of Highway 88. The August 2, 2012, stream profile indicates that around 10 percent of the streamflow at SMT originated as groundwater between SUT and SMT, and another 20 percent of the streamflow at SDT was from groundwater discharge between SMT and SDT. As a result, about 30 percent of the streamflow at SDT originated as groundwater inflow between SUT and SDT. The September 25, 2012, stream profile indicates around 15-20 percent of the streamflow at SMT originated as groundwater between SUT and SMT, and another 20-25 percent of the streamflow at SDT was from groundwater discharge between SMT and SDT. As a result, the stream gained roughly 40 percent from groundwater over the length of reach between SUT and SDT.

These results compare reasonably well with results from seepage runs conducted within a few days of the respective profiles. Seepage results on July 31, 2012, indicated an overall gain along the reach of 11 percent and on September 27, 2012, an overall gain of about 78 percent. Precise comparisons are not possible owing to seepage runs and specific conductance profiles being conducted several days apart and potential differences in stream inflows to the study reach during the two field exercises, and the specific conductance profile method does not account for any stream losses to groundwater that may occur at various points along the investigated reach. 


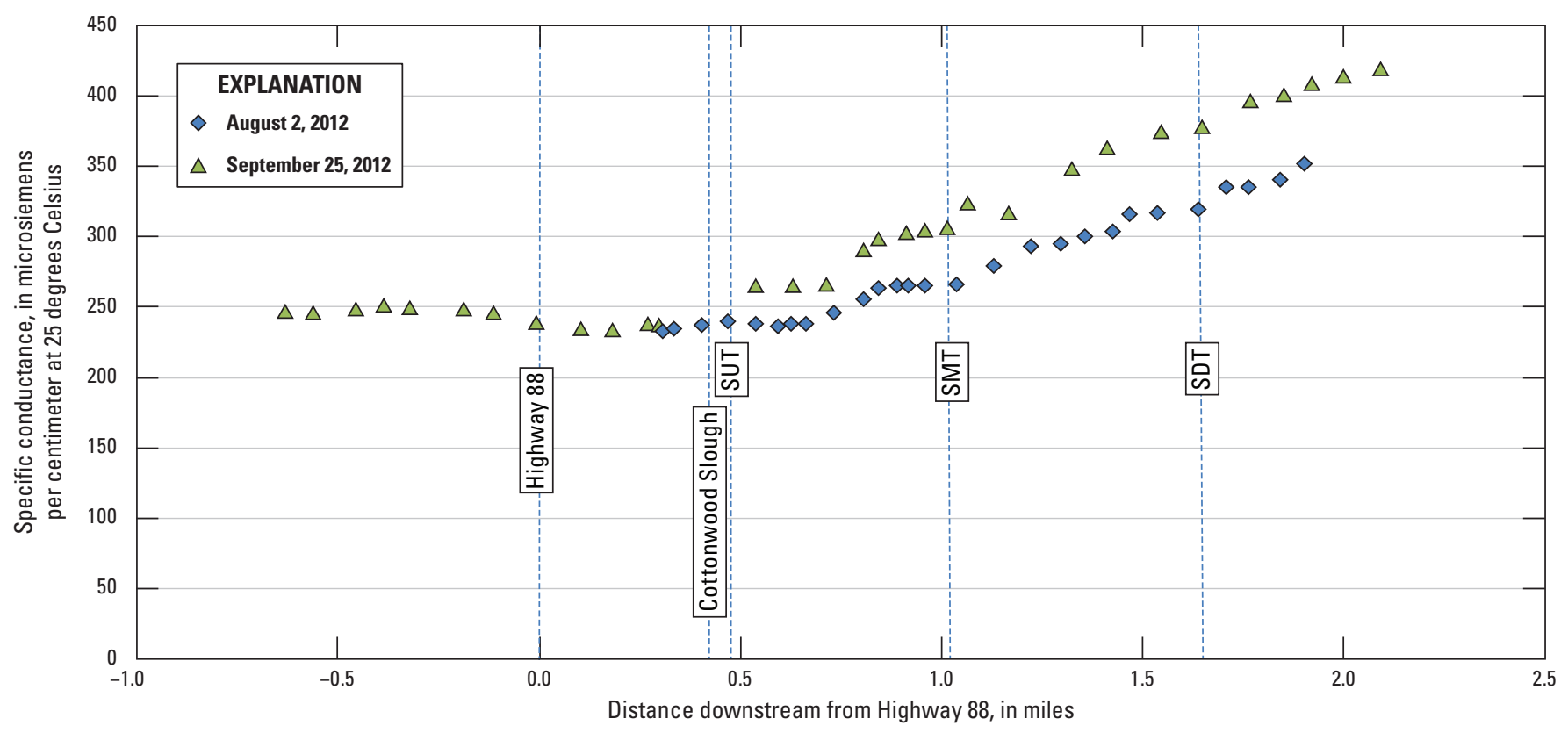

Figure 12. Longitudinal stream profiles of specific conductance along the study reach from above the stream site East Fork Carson River near Muller Lane upstream transect (SUT) to below the stream site East Fork Carson River near Muller Lane downstream transect (SDT) and includes stream site East Fork Carson River near Muller Lane middle-stream transect (SMT), August 2, 2012, and September 25, 2012, East Fork Carson River, Carson Valley, west-central Nevada.

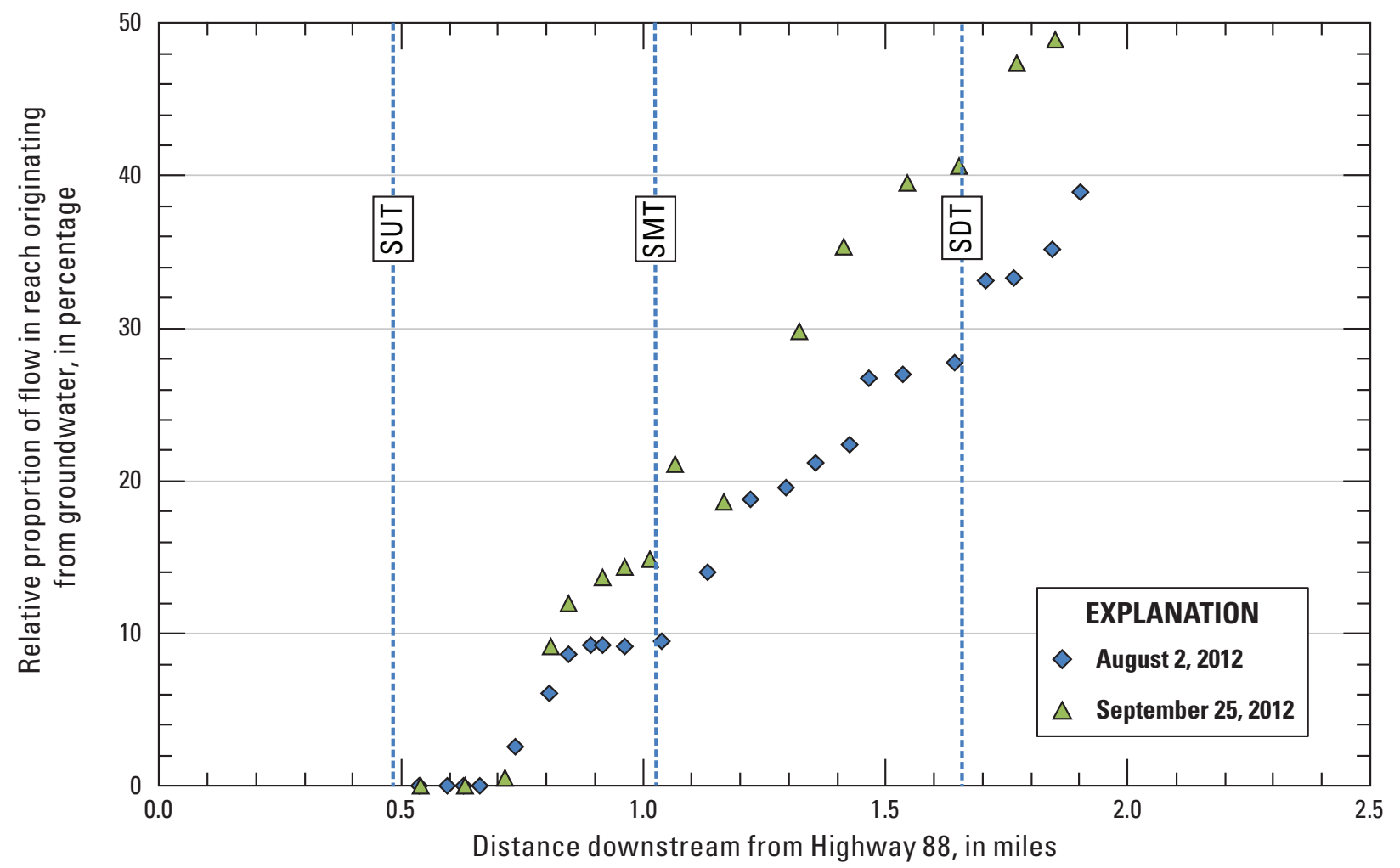

Figure 13. Relative proportion of reach streamflow originating from groundwater discharge along the study reach for specific conductance profiles collected from above the stream site East Fork Carson River near Muller Lane upstream transect (SUT) to below the stream site East Fork Carson River near Muller Lane downstream transect (SDT) and includes the stream site East Fork Carson River near Muller Lane middle-stream transect (SMT), on August 2 and September 25, 2012, East Fork Carson River, Carson Valley, westcentral Nevada. 


\section{Flow-Net Analysis}

Groundwater discharge to EFCR from the right bank was estimated using a flow-net analysis and the Darcy equation (Rosenberry and LaBaugh, 2008) for water-level conditions from September 15 to November 29, 2012. The upstream flow net corresponded to groundwater discharge entering the stream from the right bank between well transect 4 (upper) and well transect 2 (middle-stream), and the downstream flow net corresponded to groundwater discharge entering from the right bank between well transect 2 (middle-stream) and well transect 5 (lower). The Darcy equation requires values of hydraulic conductivity, the horizontal hydraulic gradient between the shallow water table and the stream surface, and the effective thickness of the aquifer. Hydraulic conductivity estimates from slug tests ranged from 10 to 110 feet per day $(\mathrm{ft} / \mathrm{d})$, indicating that the spatial variability of hydraulic properties in the shallow part of the aquifer adjacent to the stream is relatively small (table 8). An average hydraulic conductivity value of $60 \mathrm{ft} / \mathrm{d}$, based on slug tests at 10 wells, was used in the flow-net analysis. The mean horizontal hydraulic gradient perpendicular to, and in the direction towards, the EFCR for the upstream flow net was 0.003 feet per foot $(\mathrm{ft} / \mathrm{ft})$ and for the downstream flow net was $0.002 \mathrm{ft} / \mathrm{ft}$ (table 9). Effective aquifer thickness where groundwater movement occurs before discharging to the stream is unknown but for purposes of this evaluation was assumed to be $10 \mathrm{ft}$, roughly based on the maximum depths of the observation wells (table 1). Based on estimated hydraulic conductivity and gradient, and on assumed aquifer thickness, the net groundwater discharge to EFCR from the right bank between well transect 4 (upper) and well transect 5 (lower) is estimated at $0.007 \mathrm{ft}^{3} / \mathrm{s}$ (table 9). Normalized to the length of the stream reach between well transect 4 (upper) and well transect 5 (lower; $405 \mathrm{ft}$ ), groundwater discharge from the right bank along this reach is estimated at $0.093 \mathrm{ft}^{3} / \mathrm{s} / \mathrm{mi}$. Estimated groundwater discharge to EFCR using a flow-net analysis is considered a conservative, or minimum, estimate because the actual effective aquifer thickness likely is greater than $10 \mathrm{ft}$ and because this analysis only represents discharge from the right bank. A larger aquifer thickness would increase the amount of estimated groundwater discharge to the stream. The conservative estimate of groundwater discharge per stream mile based on a flow-net analysis and minimum aquifer thickness is slightly less than previously estimated reasonable bounds for groundwater discharge of $0.1-1.0 \mathrm{ft}^{3} / \mathrm{s} / \mathrm{mi}$ for gaining streams in Carson Valley (Maurer and others, 2006, p. 43).

Table 8. Site numbers, slug test information, and estimates of hydraulic conductivity at select observation wells, 2010 and 2012 , East Fork Carson River, Carson Valley, west-central Nevada.

[Site locations are shown in figures 5 and 6. Abbreviations: BGH, Butler and others (2003); BR, Bouwer and Rice (1976); ft, foot; ft/d, foot per day; mm/dd/yyyy, month/day/year; NM, not measured; USGS, U.S. Geological Survey]

\begin{tabular}{|c|c|c|c|c|c|c|c|}
\hline $\begin{array}{c}\text { USGS site } \\
\text { identification } \\
\text { number }\end{array}$ & $\begin{array}{l}\text { Site short } \\
\text { name }\end{array}$ & $\begin{array}{l}\text { Depth to water } \\
\text { from land surface } \\
\text { (ft) }\end{array}$ & $\begin{array}{c}\text { Date of slug } \\
\text { test } \\
\text { (mm/dd/yyyy) }\end{array}$ & Lithology & $\begin{array}{l}\text { Number of } \\
\text { slug tests } \\
\text { analyzed }\end{array}$ & $\begin{array}{c}\text { Slug test } \\
\text { analytical } \\
\text { method }\end{array}$ & $\begin{array}{c}\text { Hydraulic } \\
\text { conductivity } \\
\text { (ft/d) }\end{array}$ \\
\hline 385755119473705 & DRB10 & -1.44 & $11 / 16 / 2010$ & Medium sand and cobble & 3 & $\mathrm{BR}$ & 51 \\
\hline 385755119473705 & DRB10 & -1.39 & $11 / 18 / 2010$ & Medium sand and cobble & 3 & BR & 54 \\
\hline 385731119471402 & UMS3 & -1.57 & $12 / 01 / 2012$ & Sand and cobble & 3 & $\mathrm{BGH}$ & 60 \\
\hline 385731119471403 & URB4 & -1.36 & $12 / 01 / 2012$ & Sand and cobble & 3 & BR & 10 \\
\hline 385733119471505 & MLB7 & -1.17 & $12 / 01 / 2012$ & Sand and cobble & 3 & $\mathrm{BGH}$ & 91 \\
\hline 385733119471507 & MRB9 & $\mathrm{NM}$ & $11 / 29 / 2012$ & Sand and cobble & 4 & $\mathrm{BGH}$ & 90 \\
\hline 385733119471507 & MRB9 & -1 & $12 / 01 / 2012$ & Sand and cobble & 4 & $\mathrm{BGH}$ & 100 \\
\hline 385733119471508 & MRBMFS10 & NM & $11 / 29 / 2012$ & Sand and cobble & 3 & $\mathrm{BGH}$ & 28 \\
\hline
\end{tabular}


Table 9. Parameters used to calculate groundwater discharge to the study subreach using flow-net analysis, 2012, East Fork Carson River, Carson Valley, west-central Nevada.

[ft, foot; ft/d, foot per day; $\mathrm{ft}^{3} / \mathrm{s}$, cubic foot per second; $\mathrm{ft}^{3} / \mathrm{s} / \mathrm{mi}$, cubic foot per second per mile]

\begin{tabular}{|c|c|c|c|c|c|c|}
\hline $\begin{array}{c}\text { Location } \\
\text { (fig. 6) }\end{array}$ & $\begin{array}{c}\text { Mean } \\
\text { horizontal } \\
\text { hydraulic } \\
\text { gradient }\end{array}$ & $\begin{array}{l}\text { River reach } \\
\text { length } \\
\text { (ft) }\end{array}$ & $\begin{array}{l}\text { Effective } \\
\text { thickness of } \\
\text { the aquifer } \\
\text { (ft) }\end{array}$ & $\begin{array}{c}\text { Mean } \\
\text { Hydraulic } \\
\text { conductivity } \\
\text { (ft/d) }\end{array}$ & $\begin{array}{c}\text { Groundwater } \\
\text { discharge to } \\
\text { stream } \\
\left(\mathrm{ft}^{3} / \mathrm{s}\right)\end{array}$ & $\begin{array}{c}\text { Groundwater } \\
\text { discharge to } \\
\text { stream } \\
\left(\mathrm{ft}^{3} / \mathrm{s} / \mathrm{mi}\right)\end{array}$ \\
\hline $\begin{array}{l}\text { Stream reach between well transect } 4 \\
\text { (upper) and well transect } 2 \text { (middle- } \\
\text { stream) }\end{array}$ & 0.003 & 213 & 10 & 60 & 0.004 & - \\
\hline $\begin{array}{l}\text { Stream reach between well transect } 2 \\
\text { (middle-stream) and well transect } 5 \\
\text { (lower) }\end{array}$ & 0.002 & 192 & 10 & 60 & 0.003 & - \\
\hline Total & - & 405 & - & - & 0.007 & 0.093 \\
\hline
\end{tabular}

\section{Summary of Groundwater Discharge Estimates}

In summary, comparing groundwater level and stream stage and temperature data for 2010 indicates that groundwater discharge to the EFCR occurred at well transect 2 (middlestream) from both left and right banks, whereas areas surrounding well transect 1 (upstream) and well transect 3 (downstream) were losing streamflow. Evaluating seepage-run and chloride data for 2010 and 2012 demonstrated that net gains in groundwater discharge to the EFCR occurred along the overall study reach from SUT to SDT. Estimates of net groundwater discharge to EFCR for September 2010, based on seepage runs and chloride mass balance methods, ranged from 1.8 to $2.9 \mathrm{ft}^{3} / \mathrm{s} / \mathrm{mi}$ (2.0 to $3.2 \mathrm{ft}^{3} / \mathrm{s}$ ). Corresponding stream inflow to the study reach during this period (September 2010) was about $5.7 \mathrm{ft}^{3} / \mathrm{s}$, indicating that gains were on the order of 35 to 56 percent of the reach inflow.

Based on the same analysis methods (seepage runs and chloride mass balance), estimates of net groundwater discharge to the reach between SUT and SDT for the three observations in 2012 were lower than for 2010 and ranged from not detected to $1.2 \mathrm{ft}^{3} / \mathrm{s} / \mathrm{mi}\left(1.3 \mathrm{ft}^{3} / \mathrm{s}\right)$. Corresponding stream inflow to the study reach during this period in 2012 also was lower than in 2010 and ranged from 1.7 to $2.3 \mathrm{ft}^{3} / \mathrm{s}$, indicating gains were not detected to about 78 percent of reach inflow. Applying a flow-net analysis using the Darcy equation resulted in a conservative estimate of groundwater discharge to EFCR along the right bank in September 15 to November 29, 2012, between well transect 4 (upper) and well transect 5 (lower) of $0.09 \mathrm{ft}^{3} / \mathrm{s} / \mathrm{mi}\left(0.007 \mathrm{ft}^{3} / \mathrm{s}\right)$.

These methods all indicate substantial net gain in groundwater discharge between SUT and SDT during the summers of 2010 and 2012, with the majority of groundwater discharge occurring near SMT and well transect 2 (middle-stream).

\section{Water Quality}

Adequate concentrations of nitrogen and phosphorus in a stream will stimulate the growth of aquatic plants, including periphyton algae. Nutrient enrichment of a stream can promote excessive algal growth, causing degraded water quality. Background stream nutrient concentrations within the EFCR were based on nutrient concentrations at EFCR near Dresslerville, Nev. (10309010), where the EFCR enters Carson Valley and upstream of most agriculture and urban nutrient sources (fig. 1). Median concentrations of total nitrogen (TN), nitrate, ammonia, total phosphorus (TP), and orthophosphate at EFCR near Dresslerville from July to October in 1993-2004 are listed in table 10. Stream nutrient concentrations above background concentrations could mean that the stream water was enriched by anthropogenic sources.

\section{Stream Water Quality}

During the summer of 2010, stream concentrations of TN, nitrate, TP, and orthophosphate generally varied between sites and, at each stream site, decreased over time (appendix 1). The concentrations of ammonia did not change over time and were consistently low or below detection within the study reach.

In late July and early September 2010, the stream concentrations of TN and nitrate generally were higher in the study reach (appendix 1) than the background median concentrations at EFCR near Dresslerville (table 10) but lower than the median background concentrations in October 2010. The ratio of nitrate to TN at all stream sites during this period ranged from 0.04 to 0.23 , indicating the majority of nitrogen in the study reach was organic nitrogen. The stream concentrations of nitrate were highest at SMT and decreased July to October 2010. 
Table 10. Summary of stream water-quality and groundwater-quality data collected in summers 2010 and 2012, East Fork Carson River, Carson Valley, west-central Nevada.

[Site locations are shown in figures 5 and 6. Abbreviations: E, estimated; EFCR, East Fork Carson River; EPA, U.S. Environmental Protection Agency; fts/s, cubic foot per second; MCLs, maximum contaminant levels; mg/L, milligram per liter; N, nitrogen; P, phosphorus; SDT, East Fork Carson River near Muller Lane downstream transect; SMCL, secondary maximum contaminant level; SMT, East Fork Carson River near Muller Lane middle-stream transect; SUT, East Fork Carson River near Muller Lane upstream transect; TN, total nitrogen; <, less than]

\begin{tabular}{|c|c|c|c|c|}
\hline \multirow[b]{2}{*}{ Parameter } & \multicolumn{4}{|c|}{ Stream discharge measurements or sampling } \\
\hline & $\begin{array}{l}\text { Range of } \\
\text { discharge or } \\
\text { concentration }\end{array}$ & $\begin{array}{l}\text { State of Nevada } \\
\text { water-quality } \\
\text { standard } \\
\text { (mg/L) }\end{array}$ & $\begin{array}{l}\text { EFCR background } \\
\text { concentrations at EFCR } \\
\text { near Dresslerville }\end{array}$ & Summary of temporal or spatial change in discharge or concentration \\
\hline \multicolumn{5}{|c|}{2010 data collection-(1) late July, (2) early September, and (3) mid-October } \\
\hline \multicolumn{5}{|c|}{ Stream discharge } \\
\hline Stream discharge & $5.69-70 \mathrm{ft}^{3} / \mathrm{s}$ & - & - & Steamflow discharge was lowest in September and highest in October sampling events. \\
\hline \multicolumn{5}{|c|}{ Water quality } \\
\hline Total nitrogen & $<0.17-0.48 \mathrm{mg} / \mathrm{L}$ & - & $\begin{array}{l}<0.14-<0.55 \mathrm{mg} / \mathrm{L} ; \\
\quad \text { median }<0.25 \mathrm{mg} / \mathrm{L}\end{array}$ & $\begin{array}{l}\text { Highest concentrations were at SUT in July and SMT in September and October. } \\
\text { Concentrations decreased from July to October at each stream site. }\end{array}$ \\
\hline $\begin{array}{l}\text { Dissolved nitrate } \\
\text { plus nitrite }\end{array}$ & $\begin{array}{l}<0.008- \\
\quad 0.089 \mathrm{mg} / \mathrm{L} \text { as N }\end{array}$ & $10 \mathrm{mg} / \mathrm{L}$ as $\mathrm{N}$ & $\begin{array}{l}<0.06-0.07 \mathrm{mg} / \mathrm{L} \text { as } \mathrm{N} \\
\quad \text { median }<0.05 \mathrm{mg} / \mathrm{L} \text { as } \mathrm{N}\end{array}$ & $\begin{array}{l}\text { Highest concentrations were at SMT for all three sampling events. Concentrations decreased } \\
\text { from July to October at each stream site. }\end{array}$ \\
\hline $\begin{array}{l}\text { Dissolved } \\
\text { ammonia }\end{array}$ & $\begin{array}{l}<0.02-\mathrm{E} 0.02 \mathrm{mg} / \mathrm{L} \\
\quad \text { as } \mathrm{N}\end{array}$ & - & $\begin{array}{l}<0.04 \mathrm{mg} / \mathrm{L} \text { as } \mathrm{N} ; \\
\quad \text { median }<0.04 \mathrm{mg} / \mathrm{L} \text { as } \mathrm{N}\end{array}$ & $\begin{array}{l}\text { Concentrations were less than reporting level at each stream site for all three sampling events, } \\
\text { except at SUT in late July where the concentration was estimated at the reporting level. }\end{array}$ \\
\hline Total phosphorus & $0.022-0.070 \mathrm{mg} / \mathrm{L}$ & $\begin{array}{l}0.1 \mathrm{mg} / \mathrm{L} \text { annual } \\
\text { average }\end{array}$ & $\begin{array}{l}<0.01-0.22 \mathrm{mg} / \mathrm{L} \\
\quad \text { median } 0.02 \mathrm{mg} / \mathrm{L}\end{array}$ & $\begin{array}{l}\text { Concentrations were highest at SUT in July, highest at SMT in September, and concentrations } \\
\text { were similar at the three stream sites in October. Concentrations decreased from July to } \\
\text { October at each stream site. }\end{array}$ \\
\hline $\begin{array}{l}\text { Dissolved } \\
\text { orthophosphate }\end{array}$ & $\begin{array}{l}0.015-0.038 \mathrm{mg} / \mathrm{L} \\
\quad \text { as } \mathrm{P}\end{array}$ & - & $\begin{array}{l}<0.02-0.21 \mathrm{mg} / \mathrm{L} \text { as } \mathrm{P} \\
\quad \text { median }<0.02 \mathrm{mg} / \mathrm{L} \text { as } \mathrm{P}\end{array}$ & $\begin{array}{l}\text { Concentrations were slightly higher at SUT in July and decreasing downstream; } \\
\text { concentrations were similar at all three stream sites in September and October. } \\
\text { Concentrations decreased from July to October at each stream site. }\end{array}$ \\
\hline $\begin{array}{l}\text { Dissolved } \\
\text { chloride }\end{array}$ & $3.25-6.41 \mathrm{mg} / \mathrm{L}$ & - & - & $\begin{array}{l}\text { Concentrations increased from SUT to SDT for all three sampling events. Concentrations } \\
\text { increased from July to October at each stream site. }\end{array}$ \\
\hline \multicolumn{5}{|c|}{2012 data collection - (1) late July/early August, (2) late August, and (3) late September } \\
\hline \multicolumn{5}{|c|}{ Stream discharge } \\
\hline Stream discharge & $1.66-3.66 \mathrm{ft}^{3} / \mathrm{s}$ & - & - & Streamflow discharge was low and similar during all three sampling events. \\
\hline \multicolumn{5}{|c|}{ Water quality } \\
\hline Total nitrogen & $<0.29-1.10 \mathrm{mg} / \mathrm{L}$ & - & $\begin{array}{l}<0.14-<0.55 \mathrm{mg} / \mathrm{L} ; \\
\quad \text { median }<0.25 \mathrm{mg} / \mathrm{L}\end{array}$ & $\begin{array}{l}\text { Highest concentrations were at SUT in July and August and at SMT and SDT in September. } \\
\text { Concentrations generally decreased from July to September at each stream site. }\end{array}$ \\
\hline $\begin{array}{l}\text { Dissolved nitrate } \\
\text { plus nitrite }\end{array}$ & $\begin{array}{l}<0.01-0.86 \mathrm{mg} / \mathrm{L} \\
\quad \text { as } \mathrm{N}\end{array}$ & $10 \mathrm{mg} / \mathrm{L}$ as $\mathrm{N}$ & $\begin{array}{l}<0.06-0.07 \mathrm{mg} / \mathrm{L} \text { as N; } \\
\quad \text { median }<0.05 \mathrm{mg} / \mathrm{L} \text { as N }\end{array}$ & $\begin{array}{l}\text { Highest concentrations were at SUT in July and August and at SMT in September. } \\
\text { Concentrations generally decreased from July to September at each stream site. }\end{array}$ \\
\hline Dissolved nitrite & $\begin{array}{l}<0.001- \\
\quad 0.025 \mathrm{mg} / \mathrm{L} \text { as N }\end{array}$ & - & - & $\begin{array}{l}\text { Nitrite was measured at all stream sites in September and only SMT in July and not measured } \\
\text { in August. In September, concentrations were highest and the same at SMT and SDT. }\end{array}$ \\
\hline $\begin{array}{l}\text { Dissolved } \\
\text { ammonia }\end{array}$ & $\begin{array}{l}<0.01-0.01 \mathrm{mg} / \mathrm{L} \\
\quad \text { as } \mathrm{N}\end{array}$ & - & $\begin{array}{l}<0.04 \mathrm{mg} / \mathrm{L} \text { as } \mathrm{N} ; \\
\quad \text { median }<0.04 \mathrm{mg} / \mathrm{L} \text { as } \mathrm{N}\end{array}$ & Concentrations were at or less than reporting level at all three stream sites. \\
\hline
\end{tabular}


Table 10. Summary of stream water-quality and groundwater-quality data collected in summers 2010 and 2012, East Fork Carson River, Carson Valley, west-central Nevada.Continued

[Site locations are shown in figures 5 and 6. Abbreviations: E, estimated; EFCR, East Fork Carson River; EPA, U.S. Environmental Protection Agency; fts/s, cubic foot per second; MCLs, maximum contaminant levels; mg/L, milligram per liter; N, nitrogen; P, phosphorus; SDT, East Fork Carson River near Muller Lane downstream transect; SMCL, secondary maximum contaminant level; SMT, East Fork Carson River near Muller Lane middle-stream transect; SUT, East Fork Carson River near Muller Lane upstream transect; TN, total nitrogen; <, less than]

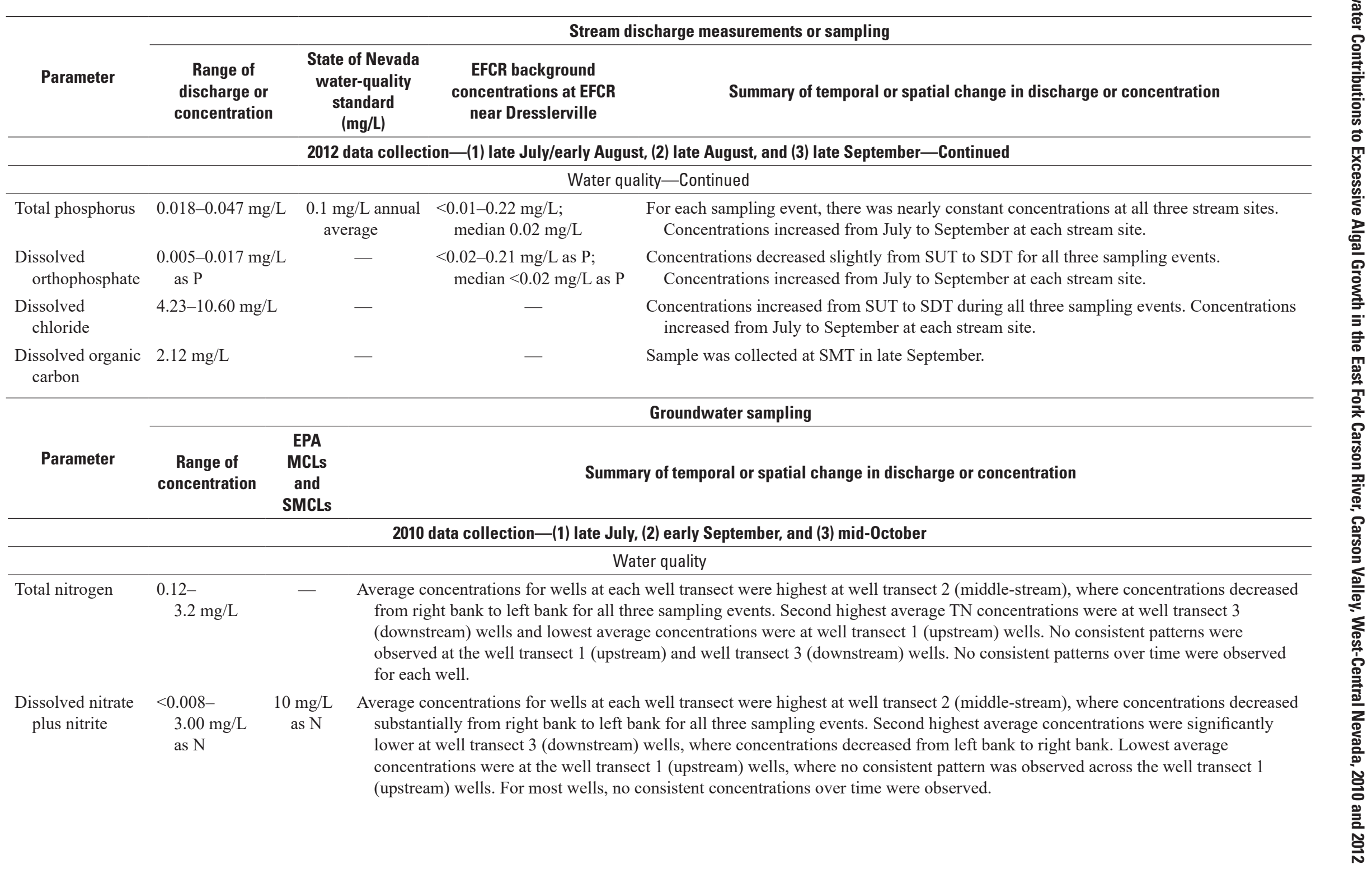


Table 10. Summary of stream water-quality and groundwater-quality data collected in summers 2010 and 2012, East Fork Carson River, Carson Valley, west-central Nevada.Continued

[Site locations are shown in figures 5 and 6. Abbreviations: E, estimated; EFCR, East Fork Carson River; EPA, U.S. Environmental Protection Agency; fts, cubic foot per second; MCLs, maximum contaminant levels; mg/L, milligram per liter; N, nitrogen; P, phosphorus; SDT, East Fork Carson River near Muller Lane downstream transect; SMCL, secondary maximum contaminant level; SMT, East Fork Carson River near Muller Lane middle-stream transect; SUT, East Fork Carson River near Muller Lane upstream transect; TN, total nitrogen; <, less than]

\begin{tabular}{|c|c|c|c|}
\hline \multirow[b]{2}{*}{ Parameter } & \multicolumn{3}{|r|}{ Groundwater sampling } \\
\hline & $\begin{array}{c}\text { Range of } \\
\text { concentration }\end{array}$ & $\begin{array}{l}\text { EPA } \\
\text { MCLs } \\
\text { and } \\
\text { SMCLs }\end{array}$ & Summary of temporal or spatial change in discharge or concentration \\
\hline \multicolumn{4}{|r|}{2010 data collection-(1) late July, (2) early September, and (3) mid-0ctober-Continued } \\
\hline \multicolumn{4}{|r|}{ Water quality-Continued } \\
\hline $\begin{array}{l}\text { Dissolved } \\
\text { ammonia }\end{array}$ & $\begin{array}{l}<0.01- \\
\quad 0.10 \mathrm{mg} / \mathrm{L} \\
\quad \text { as } \mathrm{N}\end{array}$ & - & $\begin{array}{l}\text { Highest average concentrations were at well transect } 3 \text { (downstream) wells in July and at well transect } 2 \text { (middle-stream) wells in } \\
\text { September and October. The only distinct pattern was at well transect } 3 \text { (downstream), where ammonia concentrations decreased } \\
\text { from the right bank to the left bank. Concentrations were below detection level at well transect } 1 \text { (upstream) for all three sampling } \\
\text { events. The ammonia concentrations in wells did not change during the three sampling events except at the well transect } 3 \\
\text { (downstream) middle and right bank wells, where ammonia concentrations decreased over time. }\end{array}$ \\
\hline Total phosphorus & $\begin{array}{c}0.021-0.163 \\
\mathrm{mg} / \mathrm{L}\end{array}$ & - & $\begin{array}{l}\text { Highest average concentrations for wells were at well transect } 3 \text { (downstream), where concentrations decreased from right bank to } \\
\text { left bank. Second highest average concentrations were at well transect } 2 \text { (middle-stream), where concentrations decreased from } \\
\text { right bank to mid stream and then increased to left bank. Lowest average concentrations were at well transect } 1 \text { (upstream), where } \\
\text { concentrations increased from right bank to mid stream and then decreased at left bank. For most wells, concentrations were } \\
\text { consistent over time. }\end{array}$ \\
\hline $\begin{array}{l}\text { Dissolved } \\
\text { orthophosphate }\end{array}$ & $\begin{array}{l}0.022- \\
0.148 \mathrm{mg} / \mathrm{L} \\
\text { as } \mathrm{P}\end{array}$ & - & $\begin{array}{l}\text { Highest average concentrations for wells were at well transect } 3 \text { (downstream), where concentrations decreased substantially from } \\
\text { the right bank to left bank. Second highest average concentrations were at well transect } 2 \text { (middle-stream), where concentrations } \\
\text { decreased from the right bank to the left bank. Lowest average concentrations were at well transect } 1 \text { (upstream), where } \\
\text { concentrations increased from right bank to mid-stream and then decreased at left bank. For most wells, concentrations were } \\
\text { consistent over time. }\end{array}$ \\
\hline $\begin{array}{l}\text { Dissolved } \\
\text { chloride }\end{array}$ & $\begin{array}{l}3.25- \\
\quad 16.0 \mathrm{mg} / \mathrm{L}\end{array}$ & $250 \mathrm{mg} / \mathrm{L}$ & $\begin{array}{l}\text { Highest average concentrations were at well transect } 2 \text { (middle-stream); second highest average concentrations were at well transect } 3 \\
\text { (downstream), with higher concentration on left bank away from stream than other wells in the transect. Lowest concentrations were } \\
\text { at well transect } 1 \text { (upstream) wells. Concentrations increased over time in the wells at well transect } 1 \text { (upstream) and well transect } 3 \\
\text { (downstream). }\end{array}$ \\
\hline \multicolumn{4}{|r|}{2012 data collection-(1) late July/early August, (2) late August, and (3) late September } \\
\hline \multicolumn{4}{|r|}{ Water quality } \\
\hline Total nitrogen & $\begin{array}{l}<0.08- \\
\quad 3.4 \mathrm{mg} / \mathrm{L}\end{array}$ & - & $\begin{array}{l}\text { Average concentrations were highest at well transect } 4 \text { (upper) and well transect } 5 \text { (lower); lowest at well transect } 2 \text { (middle-stream). } \\
\text { Right bank and floodplain wells at the three well transects had the highest average concentration with the exception of MRBFFS12 } \\
\text { and MRB9. The well with the highest average concentration was URB4 ( } 3.30 \mathrm{mg} / \mathrm{L} \text { ). Left bank wells at the three well transects } \\
\text { generally had the lowest concentrations. At well transect } 4 \text { (upper), concentrations increased from the left bank to the right bank, and } \\
\text { then decreased to the well in the floodplain farthest from the stream. At well transect } 2 \text { (middle-stream), concentrations increased } \\
\text { from the left bank to the well located mid-floodplain, and then decreased to the well in the floodplain farthest from the stream. } \\
\text { At well transect } 5 \text { (lower), concentrations generally increase from left bank to right bank, and then increased to the well in the } \\
\text { floodplain farthest from the stream. For most wells, concentrations showed minor variation during all three sampling events. }\end{array}$ \\
\hline
\end{tabular}


Table 10. Summary of stream water-quality and groundwater-quality data collected in summers 2010 and 2012, East Fork Carson River, Carson Valley, west-central Nevada.Continued

[Site locations are shown in figures 5 and 6. Abbreviations: E, estimated; EFCR, East Fork Carson River; EPA, U.S. Environmental Protection Agency; $\mathrm{ft}^{3} / \mathrm{s}$, cubic foot per second; MCLs, maximum contaminant levels; mg/L, milligram per liter; N, nitrogen; P, phosphorus; SDT, East Fork Carson River near Muller Lane downstream transect; SMCL, secondary maximum contaminant level; SMT, East Fork Carson River near Muller Lane middle-stream transect; SUT, East Fork Carson River near Muller Lane upstream transect; TN, total nitrogen; <, less than]

\begin{tabular}{|c|c|c|c|}
\hline \multirow[b]{2}{*}{ Parameter } & \multicolumn{3}{|r|}{ Groundwater sampling } \\
\hline & $\begin{array}{c}\text { Range of } \\
\text { concentration }\end{array}$ & $\begin{array}{l}\text { EPA } \\
\text { MCLs } \\
\text { and } \\
\text { SMCLs }\end{array}$ & Summary of temporal or spatial change in discharge or concentration \\
\hline \multicolumn{4}{|r|}{2012 data collection-(1) late July/early August, (2) late August, and (3) late September-Continued } \\
\hline \multicolumn{4}{|r|}{ Water quality-Continued } \\
\hline $\begin{array}{l}\text { Dissolved nitrate } \\
\text { plus nitrite }\end{array}$ & $\begin{array}{l}<0.01- \\
\quad 3.29 \mathrm{mg} / \mathrm{L} \\
\text { as } \mathrm{N}\end{array}$ & $\begin{array}{c}10 \mathrm{mg} / \mathrm{L} \\
\text { as } \mathrm{N}\end{array}$ & $\begin{array}{l}\text { Average concentrations were highest at well transect } 4 \text { (upper) and well transect } 5 \text { (lower); lowest at well transect } 2 \text { (middle-stream). } \\
\text { Right bank and floodplain wells at the three well transects had the highest average concentrations with the exception of MRBFFS12 } \\
\text { and MRB9. The well with the highest average concentration was URB4 ( } 3.15 \mathrm{mg} / \mathrm{L} \text { as N). Left bank wells at the three well transects } \\
\text { had the lowest concentrations. At well transect } 4 \text { (upper), concentrations increased from the left bank to the right bank, and then } \\
\text { decreased to the well in the floodplain farthest from the stream. At well transect } 2 \text { (middle-stream), concentrations increased from } \\
\text { the left bank to the well located mid-floodplain, and then decreased to the well in the floodplain farthest from the stream. At well } \\
\text { transect } 5 \text { (lower), concentrations generally increased from left bank to right bank, and then increased to the well in the floodplain } \\
\text { farthest from the stream. For most wells, concentrations showed minor variation during all three sampling events. }\end{array}$ \\
\hline Dissolved nitrite & $\begin{array}{l}<0.001- \\
0.106 \mathrm{mg} / \mathrm{L} \\
\text { as N }\end{array}$ & $\begin{array}{r}1 \mathrm{mg} / \mathrm{L} \\
\text { as } \mathrm{N}\end{array}$ & $\begin{array}{l}\text { Samples were collected from two wells in early August and all wells in September. Average concentrations were highest at well } \\
\text { transect } 5 \text { (lower), and lowest at well transect } 4 \text { (upper) and well transect } 2 \text { (middle-stream). Highest concentrations tended to be at } \\
\text { right bank and right bank floodplain wells, with lowest concentrations at the left bank. The well with the highest concentration was } \\
\text { MRBFFS10 ( } 0.106 \mathrm{mg} / \mathrm{L} \text { as } \mathrm{N} \text { ). For well transect } 4 \text { (upper) and well transect } 5 \text { (lower), the concentrations increased from the left } \\
\text { back to right bank far floodplain wells. At well transect } 2 \text { (middle-stream), the concentrations increased from left bank to the right } \\
\text { bank mid-floodplain well, then decreased to the right bank far floodplain well. }\end{array}$ \\
\hline $\begin{array}{l}\text { Dissolved } \\
\text { ammonia }\end{array}$ & $\begin{array}{l}<0.01- \\
0.10 \mathrm{mg} / \mathrm{L} \\
\text { as } \mathrm{N}\end{array}$ & - & $\begin{array}{l}\text { Average concentrations were highest at left bank wells. Most of the concentrations were below or at the detection limit at right bank } \\
\text { and right bank floodplain wells. The well with the highest average concentration was DLB14 }(0.08 \mathrm{mg} / \mathrm{L} \text { as N). For most wells, } \\
\text { concentrations showed minor variation during all three sampling events. }\end{array}$ \\
\hline Total phosphorus & $\begin{array}{l}0.018- \\
\quad 0.370 \mathrm{mg} / \mathrm{L}\end{array}$ & - & $\begin{array}{l}\text { Average concentrations were highest at well transect } 2 \text { (middle-stream) and well transect } 5 \text { (lower), lowest at well transect } 4 \text { (upper). } \\
\text { For most wells, the left bank, right bank, and right bank floodplain wells had the highest average concentrations. The well with the } \\
\text { highest average concentration was MRBFFS12 }(0.306 \mathrm{mg} / \mathrm{L} \text { ). Average concentrations at two wells at well transect } 2 \text { (middle-stream) } \\
\text { and three wells at well transect } 5 \text { (lower) were above } 0.1 \mathrm{mg} / \mathrm{L} \text {, the stream water-quality standard for total phosphorus. For all three } \\
\text { well transects, the concentration decreased from the left back to mid-stream, and then increased to the right bank far floodplain } \\
\text { wells. For most wells, concentrations showed minor variation during all three sampling events. }\end{array}$ \\
\hline $\begin{array}{l}\text { Dissolved } \\
\text { orthophosphate }\end{array}$ & $\begin{array}{l}0.008- \\
0.339 \mathrm{mg} / \mathrm{L} \\
\quad \text { as } \mathrm{P}\end{array}$ & - & $\begin{array}{l}\text { Average concentrations were highest at well transect } 2 \text { (middle-stream), followed by well transect } 5 \text { (lower), and lowest at well } \\
\text { transect } 4 \text { (upper). The right bank and right bank floodplain wells had the highest average concentrations. The well with the } \\
\text { highest average concentration was MRBFFS12 }(0.280 \mathrm{mg} / \mathrm{L} \text { as P). Average concentrations at one well at well transect } 2 \text { (middle- } \\
\text { stream) and two wells at well transect } 5 \text { (lower) were above } 0.1 \mathrm{mg} / \mathrm{L} \text { as P, the stream water-quality standard for total phosphorus. } \\
\text { At well transect } 4 \text { (upper), concentrations increased from the left bank to the right bank far floodplain well. At well transect } 2 \\
\text { (middle-stream), concentrations generally increased from left bank to the right bank far floodplain well. At well transect } 5 \text { (lower), } \\
\text { concentrations decreased from the left back to mid-stream, and then increased to the right bank far floodplain well. About half the } \\
\text { wells showed minor variation in concentrations during all three sampling events. }\end{array}$ \\
\hline
\end{tabular}


Table 10. Summary of stream water-quality and groundwater-quality data collected in summers 2010 and 2012, East Fork Carson River, Carson Valley, west-central Nevada.Continued

[Site locations are shown in figures 5 and 6. Abbreviations: E, estimated; EFCR, East Fork Carson River; EPA, U.S. Environmental Protection Agency; fts/s, cubic foot per second; MCLs, maximum contaminant levels; mg/L, milligram per liter; N, nitrogen; P, phosphorus; SDT, East Fork Carson River near Muller Lane downstream transect; SMCL, secondary maximum contaminant level; SMT, East Fork Carson River near Muller Lane middle-stream transect; SUT, East Fork Carson River near Muller Lane upstream transect; TN, total nitrogen; <, less than]

\begin{tabular}{|c|c|c|c|}
\hline \multirow[b]{2}{*}{ Parameter } & \multicolumn{3}{|r|}{ Groundwater sampling } \\
\hline & $\begin{array}{c}\text { Range of } \\
\text { concentration }\end{array}$ & $\begin{array}{l}\text { EPA } \\
\text { MCLs } \\
\text { and } \\
\text { SMCLs }\end{array}$ & Summary of temporal or spatial change in discharge or concentration \\
\hline \multicolumn{4}{|r|}{2012 data collection-(1) late July/early August, (2) late August, and (3) late September-Continued } \\
\hline \multicolumn{4}{|r|}{ Water quality-Continued } \\
\hline $\begin{array}{l}\text { Dissolved } \\
\text { chloride }\end{array}$ & $\begin{array}{l}4.51- \\
\quad 24.6 \mathrm{mg} / \mathrm{L}\end{array}$ & - & $\begin{array}{l}\text { Average concentrations were highest at well transect } 5 \text { (lower), followed by well transect } 4 \text { (upper) and lowest at well transect } 2 \\
\text { (middle-stream). Right bank and floodplain wells at the three well transects had the highest average concentration with the exception } \\
\text { of MRBFFS12 and MRB9. At well transect } 4 \text { (upper) and well transect } 5 \text { (lower), concentrations increased from left bank to right } \\
\text { bank far floodplain wells. }\end{array}$ \\
\hline $\begin{array}{l}\text { Dissolved organic } \\
\text { carbon }\end{array}$ & $\begin{array}{l}0.72- \\
10.8 \mathrm{mg} / \mathrm{L}\end{array}$ & - & $\begin{array}{l}\text { Samples were collected from eight wells during September (table 3). Highest concentrations were at the right bank and right bank } \\
\text { floodplain wells. }\end{array}$ \\
\hline
\end{tabular}


Similarly, the TP concentrations at all stream sites in July, September, and October 2010, and the orthophosphate concentrations in July and September 2010 (appendix 1), were generally higher than background median concentrations. The concentrations of TP and orthophosphate decreased from SUT to SDT in July, whereas in September, the highest TP concentration was at SMT and orthophosphate concentrations were similar at all stream sites. In October, the concentrations of TP were similar at the three stream sites, and orthophosphate concentrations were also similar at the three stream sites. The ratio of orthophosphate to total phosphorus concentration ranged from 0.35 to 0.69 with a median of 0.54 , indicating 54 percent of the total phosphorus was orthophosphate. These results vary from findings of Alvarez and Seiler (2004) who found much lower ratios in July and August of 2002 at a site on EFCR at Muller Lane, just downstream from SDT, even though streamflow conditions were similar. The N:P ratio at all three stream sites in July, September, and October 2010 indicated potential nitrogen limitation; in other words, periphyton productivity may have been limited by the amount of nitrogen available for uptake.

In comparison to stream nutrient concentrations in 2010 , 2012 stream concentrations were higher for TN and nitrate and lower for TP and orthophosphate; ammonia concentrations were similar in both years (appendixes 1 and 2). Stream nutrient concentrations changed spatially in summer 2012, and similar to 2010, TN and nitrate concentrations generally decreased during the summer, from July to September, at all stream sites (appendix 2). Ammonia concentrations did not change over time within the study reach during summer 2012 and were consistently low or below detection limits. However, in contrast to 2010, TP and orthophosphate concentrations increased during the summer. Moreover, nitrite was measured in 2012 in four stream samples and was found to be much lower than nitrate (less than 7.5 percent of the nitrate plus nitrite concentration was nitrite); hence, nitrate was the primary inorganic nitrogen species in the stream. During the sampling events in 2012, the N:P ratio at the three stream sites fluctuated over time, indicating that the limiting nutrient changed from phosphorus in July to nitrogen in September.

At all stream sites in July 2012, stream TN and nitrate concentrations (appendix 2) generally were much higher than the median background concentrations (table 10). The ratio of nitrate to TN at SUT was elevated at 0.78 , indicating the majority of nitrogen entering the study reach in July was inorganic nitrogen (nitrate). Concentrations of TN and nitrate and the ratio of nitrate to TN generally decreased over time at all stream sites from July to September. During this period, the highest TN and nitrate concentrations shifted from being at SUT in July to SMT and SDT in September. By late September, TN concentrations at SUT were similar to background median concentrations, nitrate was below detection, and the ratio of nitrate to TN was substantially lower at about 0.03 , indicating almost all of the nitrogen entering the study reach from upstream was organic nitrogen. In contrast, by late September 2012, TN and nitrate concentrations were above median background concentrations at SMT and SDT.

Although stream TP concentrations were generally similar throughout the study reach for any given time in summer 2012, concentrations increased at all stream sites from July to September (appendix 2). This was also true for orthophosphate concentrations. In July, TP and orthophosphate concentrations at all stream sites were similar to median background concentrations (table 10). However, by September, TP concentrations were above median background concentrations, whereas orthophosphate concentrations were similar to median background concentrations at stream sites.

The ratio of orthophosphate to total phosphorus ranged from 0.25 to 0.47 with a median of 0.32 in stream samples collected in 2012. These results indicate the majority of total phosphorus was from particulate phosphorus and are consistent with the findings of Alvarez and Seiler (2004). For phosphorus species, only total phosphorus and orthophosphate were measured in water samples, and for this study, particulate phosphorus is estimated as total phosphorus minus orthophosphate. Particulate phosphorus defined this way includes phosphorus bound to clays, minerals, and decaying organic matter; phosphorus incorporated into living tissue; and phosphorus in dissolved non-orthophosphate forms (Alvarez and Seiler, 2004).

\section{Comparison to Historical Water Quality}

Stream water quality at the study reach during the summer and fall of 2010 and 2012 was similar to historical water quality at two NDEP long-term water-quality monitoring sites upstream and downstream of the study reach. Water quality at sites SUT, SMT, and SDT were compared to (1) NDEP site C16, East Fork Carson River at Highway 88, upstream of the study reach and (2) NDEP site C15, East Fork Carson River at Williams Slough (where EFCR crosses Muller Lane), downstream of the study reach (fig. 1; data available at https://nevadawaterquality.ndep.nv.gov/). Only NDEP data from July through September 1988-2004 were used because these data are comparable to the sampling period of this study. Prior to 1988, treated wastewater was permitted to be discharged to the stream upstream of the monitoring sites; therefore, those data are not included, and no data has been collected since 2004. Stream concentrations of chloride, total Kjeldahl nitrogen, dissolved nitrate, total phosphorus, orthophosphate, dissolved oxygen, and $\mathrm{pH}$ at SUT, SMT, and SDT during 2010 and 2012 were similar to historical concentrations at the NDEP monitoring sites upstream (C16) and downstream (C15) of the study reach (table 11). Historical summer specific conductance values varied from 61 to $278 \mu \mathrm{S} / \mathrm{cm}$ upstream of the study reach and from 63 to $346 \mu \mathrm{S} / \mathrm{cm}$ just downstream. Discrete readings of specific conductance at SUT, SMT, and SDT in 2010 and 2012 were similar $(183-373 \mu \mathrm{S} / \mathrm{cm})$. Both the historical and study reach data show a general increase in specific conductance from upstream to downstream. 
Table 11. Summary of minimum, median, and maximum concentrations of selected constituents sampled at historic Nevada Division of Environmental Protection sites and at study stream sites in summer 2010 and summer 2012, East Fork Carson River, Carson Valley, westcentral Nevada.

[Site locations are shown in figures 1, 5, and 6. Abbreviations: Hwy, Highway; mg/L, milligram per liter; N, nitrogen; No., number; P, phosphorus; SDT, East Fork Carson River near Muller Lane downstream transect; SMT, East Fork Carson River near Muller Lane middle-stream transect; SUT, East Fork Carson River near Muller Lane upstream transect; $<$, less than; $\mu \mathrm{S} / \mathrm{cm}$, microsiemen per centimeter at 25 degrees Celsius]

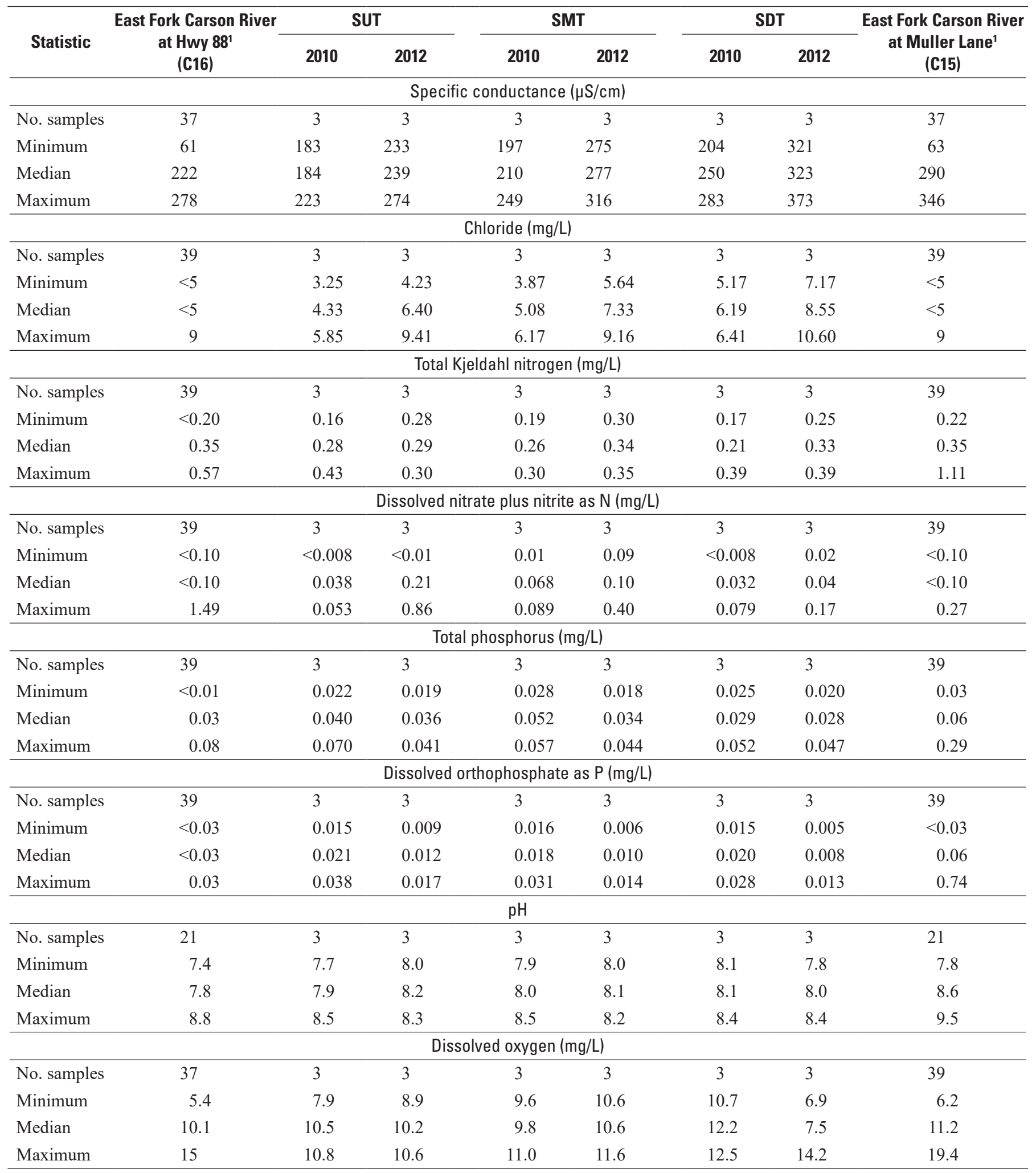

${ }^{1}$ Based upon measurements taken from 1988 to 2004 during the months of July through September. 


\section{Comparison to Water-Quality Standards and Reference Criteria}

Stream water quality based on six discrete stream samples collected during the summer and fall of 2010 and 2012 were compared to applicable State of Nevada stream water-quality standards (table 12). Water quality at SUT, SMT, and SDT did not exceed the selected State waterquality standards for temperature, $\mathrm{DO}, \mathrm{pH}$, total phosphorus, or nitrate during 2010 or 2012 based on the discrete stream samples (table 11); however, flow conditions during 2012 were extremely low, and State water-quality standards may not have been applicable for part of the summer. Nevada Administrative Code (NAC) 445.121(8) states, "The specified standards are not considered violated when the natural conditions of the receiving water are outside the established limits, including periods of extreme high or low flow..." (Nevada Administrative Code, 2013). For implementing NAC 445.121(8), the low- and high-flow thresholds are typically defined using 7Q10 statistics (Nevada Division of Environmental Protection, 2004). The 7Q10 statistic is the average 7 consecutive day minimum streamflow that can be expected to occur once every 10 years. However, no longterm stream gaging station records are available that would be representative of conditions in the study reach.

Stream samples from the study reach were not analyzed for total dissolved solids (TDS); however, approximate concentrations were estimated from specific conductance measurements in order to compare TDS with the State of Nevada water-quality standards. Hem (1985) indicated that, for natural waters, TDS (in $\mathrm{mg} / \mathrm{L}$ ) mostly ranged between $0.55-0.75$ of the specific conductance value (in $\mu \mathrm{S} / \mathrm{cm}$ ). A factor of 0.67 often is used to estimate TDS concentrations from specific conductance measurements when the actual factor is not known (U.S. Department of the Interior, November 1998, p. 129). The higher values (>0.70) are associated with water high in sulfate (U.S. Department of

Table 12. Nevada Division of Environmental Protection stream water-quality standards for selected constituents.

$[\mathrm{mg} / \mathrm{L}$, milligram per liter; $\mathrm{N}$, nitrogen; $\leq$, less than or equal to; $\geq$, greater than or equal to; ${ }^{\circ} \mathrm{C}$, degree Celsius]

\begin{tabular}{lc}
\hline \multicolumn{1}{c}{ Parameter } & Water-quality standard ${ }^{1}$ \\
\hline Temperature & June: $\leq 17{ }^{\circ} \mathrm{C}$ \\
Temperature & July: $\leq 21^{\circ} \mathrm{C}$ \\
Temperature & August-October: $\leq 22^{\circ} \mathrm{C}$ \\
Dissolved oxygen & June-October: $\geq 5.0 \mathrm{mg} / \mathrm{L}$ \\
pH & $6.5-9.0$ \\
Total phosphorus (annual average) & $0.1 \mathrm{mg} / \mathrm{L}$ \\
Nitrate as N & $10 \mathrm{mg} / \mathrm{L}$ \\
Total dissolved solids (annual average) & $500 \mathrm{mg} / \mathrm{L}$ \\
Chloride & $250 \mathrm{mg} / \mathrm{L}$ \\
\hline
\end{tabular}

${ }^{1}$ From Nevada Administrative Code 445A.1806 (2013). the Interior, November 1998, p. 129). Using the range of conversion factors, the estimated range in TDS values were 101 to $280 \mathrm{mg} / \mathrm{L}$ which were considerably lower than the State water-quality standard of $500 \mathrm{mg} / \mathrm{L}$.

Continuous water temperature, $\mathrm{DO}$, and $\mathrm{pH}$ conditions were measured at SDT during part of the summers of 2010 and 2012 (fig. 14) and compared to the State of Nevada water-quality standards (table 12) and reference criteria. As previously mentioned, streamflow conditions may have been low enough during the summer of 2012 that the waterquality standards may not have been applicable. However, the comparison is made to give context of whether the water temperature, $\mathrm{DO}$, and $\mathrm{pH}$ conditions in the stream exceeded established criteria and give an indication of the effects of algae on stream health.

Water temperature affects the health and ecology of the stream. For example, the amount of oxygen dissolved in a stream is partly dependent on the stream temperature, and the rate of photosynthesis by algae is influenced by the water temperature. High water temperatures can stress aquatic organisms. Based upon the continuous data, the State standard of $21{ }^{\circ} \mathrm{C}$ in July and $22{ }^{\circ} \mathrm{C}$ in August and September commonly was exceeded (table 13). During the 2010 measurement period, the State water temperature standard was exceeded 100 percent of days in August and 46 percent of days in September. During the 2012 measurement period, the State water temperature standard was exceeded on all days, and the average daily maximum temperatures $\left(27.4{ }^{\circ} \mathrm{C}\right.$ in July and $28.2^{\circ} \mathrm{C}$ in August) were well above the state temperature standard. The average daily minimum and maximum temperatures were higher in 2012 compared to 2010. Lower streamflow in 2012 likely contributed to the higher stream temperature and exceedances of State standards.

Table 13. Summary of exceedances of the State of Nevada temperature water-quality standard at stream site East Fork Carson River near Muller Lane downstream transect (SDT), 2010 and 2012, East Fork Carson River, Carson Valley, west-central Nevada.

$\left[{ }^{\circ} \mathrm{C}\right.$, degree Celsius; >, greater than $]$

\begin{tabular}{ccccc}
\hline $\begin{array}{c}\text { Month } \\
\text { and } \\
\text { year }\end{array}$ & $\begin{array}{c}\text { Total } \\
\text { days } \\
\text { monitored }\end{array}$ & $\begin{array}{c}\text { Average } \\
\text { daily } \\
\text { minimum } \\
\text { temperature } \\
\left({ }^{\circ} \mathbf{C}\right)\end{array}$ & $\begin{array}{c}\text { Average } \\
\text { daily } \\
\text { maximum } \\
\text { temperature } \\
\left({ }^{\circ} \mathbf{C}\right)\end{array}$ & $\begin{array}{c}\text { Days } \\
\text { with } \\
\text { temperature } \\
\mathbf{2 1 / 2 2}{ }^{\circ} \mathbf{C}^{1} \\
(\text { percentage) }\end{array}$ \\
\hline $\begin{array}{c}\text { August } \\
2010\end{array}$ & 22 & 15.2 & 24.7 & 100 \\
$\begin{array}{c}\text { September } \\
2010\end{array}$ & 24 & 12.9 & 22.1 & 46 \\
$\begin{array}{c}\text { July 2012 } \\
\text { August }\end{array}$ & 11 & 16.2 & 27.4 & 100 \\
2012 & 16 & 16.6 & 28.2 & 100 \\
\hline
\end{tabular}

${ }^{1} \mathrm{July}$ standard is $21^{\circ} \mathrm{C}$; August-October standard is $22^{\circ} \mathrm{C}$. 

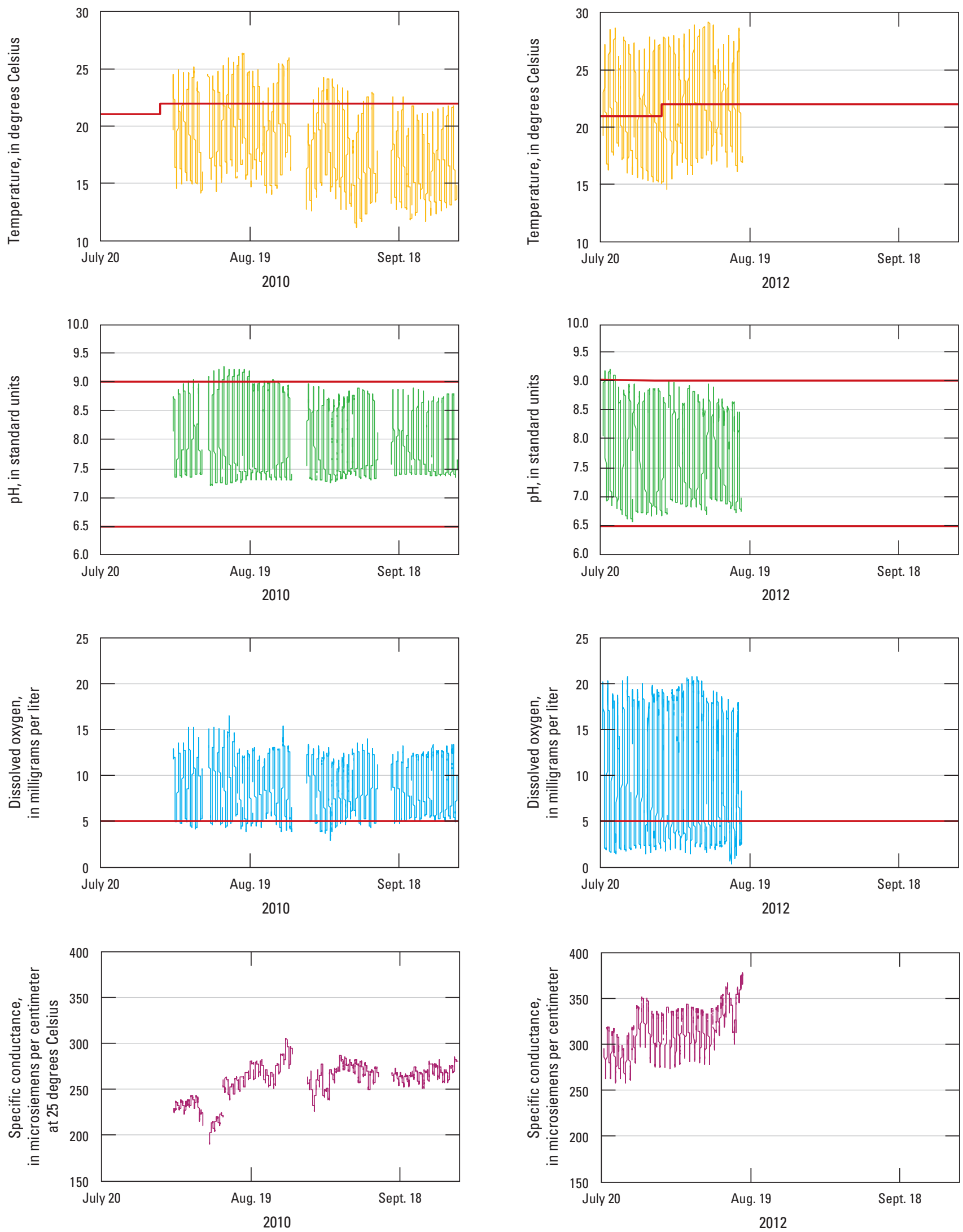

Figure 14. Water temperature, $\mathrm{pH}$, dissolved oxygen, and specific conductance at stream site East Fork Carson River near Muller Lane downstream transect (SDT), August 3-September 29, 2010, and July 20-August 17, 2012, East Fork Carson River, Carson Valley, westcentral Nevada. Red line depicts State of Nevada water-quality standards. 
Sufficient DO concentrations in the stream are critical to the health of aquatic animals. Photosynthesis and respiration are important processes that effect DO concentrations in streams. During the day, photosynthesis by algae and other aquatic plants results in increased DO concentrations in the afternoon. Nighttime respiration by aquatic plants and bacteria creates a demand on DO, resulting in early morning lows. Low DO concentrations can be a problem for aquatic animals and in some streams may drop below the State standard of $5 \mathrm{mg} / \mathrm{L}$. In addition, as algae die and decompose, high levels of organic matter are added to the stream substrate, and the decomposing organisms deplete the water of available DO (Art, 1993). Daily metabolic cycles of the periphyton-dominated community in the study reach produced DO concentrations at SDT that at times did not meet the State water-quality standards (figs. 14 and 15). For some days, the continuous DO data was erratic particularly during periods of peak DO (fig. 15). During the 2010 measurement period, DO concentrations did not meet the State water-quality standard on 77 percent of days in August and 50 percent of days in September (table 14). During the 2012 measurement period, DO concentrations did not meet the State water-quality standard on all days, and daily minimum concentrations averaged $1.9 \mathrm{mg} / \mathrm{L}$ in July and $2.0 \mathrm{mg} / \mathrm{L}$ in September, compared to $4.6 \mathrm{mg} / \mathrm{L}$ in August 2010 and $4.8 \mathrm{mg} / \mathrm{L}$ in September 2010. The average daily maximum DO concentrations were higher in 2012 than 2010. The most extreme DO swings based on the average daily maximum and minimum DO concentrations were in
July 2012, from 1.9 to $19.5 \mathrm{mg} / \mathrm{L}$, and are an indication of the high level of productivity in the stream. Lower streamflow, higher stream temperatures, and higher algal biomass in 2012 likely contributed to lower DO concentrations in the stream and more frequent exceedances of State standards.

Table 14. Summary of exceedances of the State of Nevada dissolved oxygen water-quality standard at stream site East Fork Carson River near Muller Lane downstream transect (SDT), 2010 and 2012, East Fork Carson River, Carson Valley, west-central Nevada.

$[\mathrm{mg} / \mathrm{L}$, milligram per liter; $<$, less than $]$

\begin{tabular}{ccccc}
\hline $\begin{array}{c}\text { Month } \\
\text { and } \\
\text { year }\end{array}$ & $\begin{array}{c}\text { Total } \\
\text { days } \\
\text { monitored }\end{array}$ & $\begin{array}{c}\text { Average } \\
\text { daily } \\
\text { minimum } \\
\text { dissolved } \\
\text { oxygen } \\
\text { (mg/L) }\end{array}$ & $\begin{array}{c}\text { Average } \\
\text { daily } \\
\text { maximum } \\
\text { dissolved } \\
\text { oxygen } \\
\text { (mg/L) }\end{array}$ & $\begin{array}{c}\text { Days } \\
\text { with } \\
\text { dissolved } \\
\text { oxygen } \\
<5 \text { mg/L } \\
\text { (percentage) }\end{array}$ \\
\hline $\begin{array}{c}\text { August } \\
\text { 2010 }\end{array}$ & 22 & 4.6 & 13.8 & 77 \\
$\begin{array}{c}\text { September } \\
2010\end{array}$ & 24 & 4.8 & 12.7 & 50 \\
$\begin{array}{c}\text { July 2012 } \\
\text { August }\end{array}$ & 10 & 1.9 & 19.5 & 100 \\
2012 & 16 & 2.0 & 19.3 & 100 \\
\hline
\end{tabular}

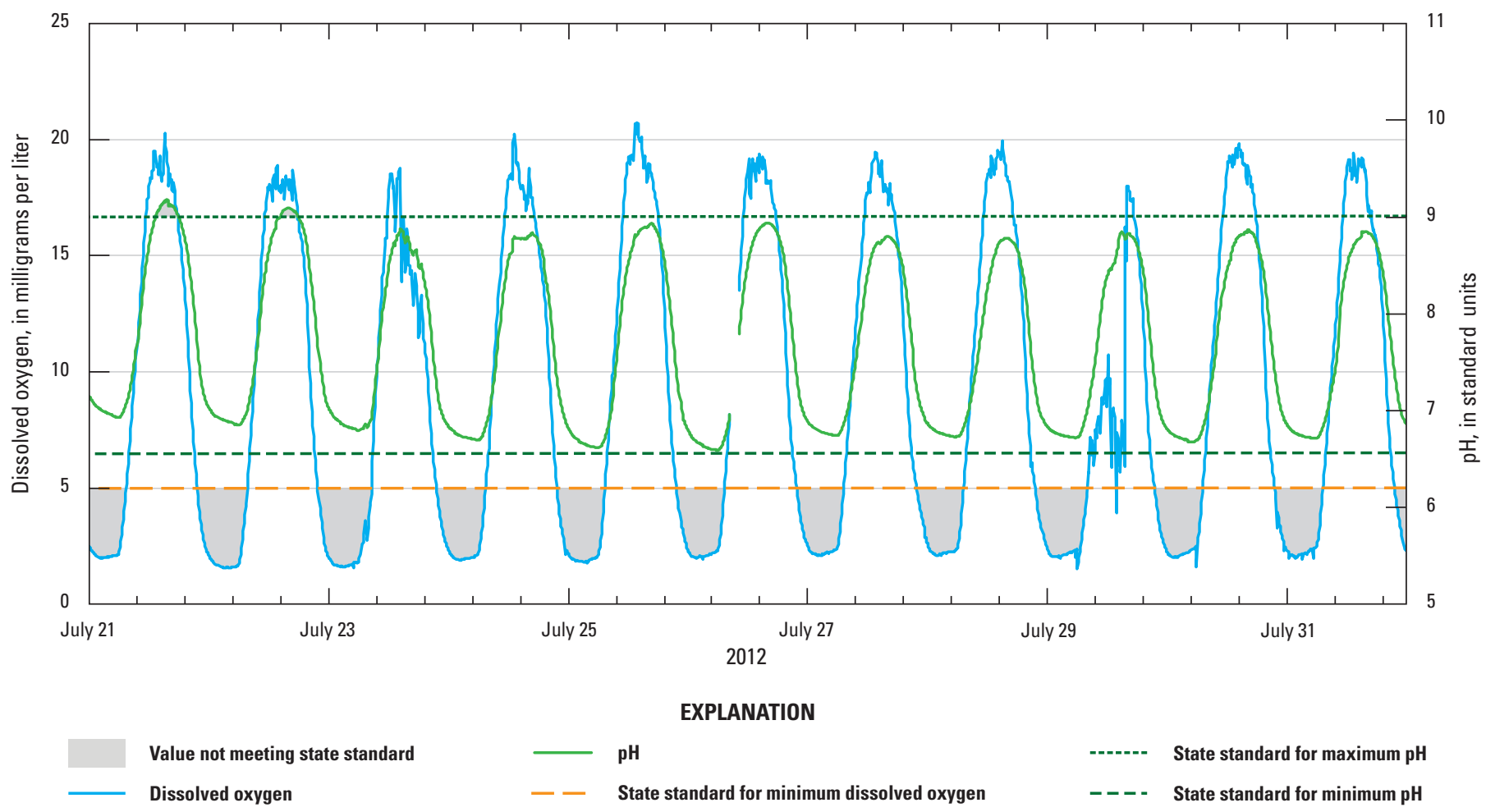

Figure 15. Daily fluctuation in dissolved oxygen and pH, July 21-31, 2012, at stream site East Fork Carson River near Muller Lane downstream transect (SDT), East Fork Carson River, Carson Valley, west-central Nevada. 
Minimum percent DO saturation is a common metric used by other states in stream health assessments, although it is not currently included as a component of the State of Nevada water-quality standards. Dissolved oxygen saturation values below 50 percent are known to be harmful to many aquatic organisms (Dodds, 2007). During the 2010 measurement period, DO saturation values dropped below the 50-percent threshold on 9 percent of days in August and 13 percent of days in September (table 15). The DO saturation values in 2012 dropped below the 50-percent threshold for all measurement days. The high values of average daily maximum dissolved oxygen saturation during 2012 indicate the stream was supersaturated, which can be harmful to fish. The large contrast in the average daily minimum and maximum DO saturation values in July 2012 (22 and 290-percent saturation, respectively) is an indicator of the large amount of oxygen consumed and produced in a given day during the measurement period.

The presence of algae also caused daily $\mathrm{pH}$ fluctuations in the stream, resulting in exceedances of the State of Nevada stream $\mathrm{pH}$ standard. The average daily maximum $\mathrm{pH}$ ranged from 8.8 to 9.1 relative to the standard of 9.0. Photosynthesis and respiration also influence carbon dioxide levels, which influences carbonate related equilibria. Changes in carbonate equilibria lead to changes in $\mathrm{pH}$. As carbon dioxide is consumed and transformed during photosynthesis, water becomes more basic, resulting in afternoon high $\mathrm{pH}$ values. In contrast, respiration introduces more carbon dioxide into the water, leading to low $\mathrm{pH}$ conditions during the early morning. Low and high $\mathrm{pH}$ can negatively affect aquatic life. During the 2010 measurement period, the State $\mathrm{pH}$ standards were exceeded on 36 percent of days in August but not exceeded

Table 15. Summary of exceedances of the State of Nevada dissolved oxygen saturation guideline at stream site East Fork Carson River near Muller Lane downstream transect (SDT), 2010 and 2012, East Fork Carson River, Carson Valley, west-central Nevada.

$[<$, less than $]$

\begin{tabular}{ccccc}
\hline $\begin{array}{c}\text { Month } \\
\text { and } \\
\text { year }\end{array}$ & $\begin{array}{c}\text { Total } \\
\text { days } \\
\text { monitored }\end{array}$ & $\begin{array}{c}\text { Average } \\
\text { daily } \\
\text { minimum } \\
\text { dissolved } \\
\text { oxygen } \\
\text { saturation } \\
\text { (percentage) }\end{array}$ & $\begin{array}{c}\text { Average } \\
\text { daily } \\
\text { maximum } \\
\text { dissolved } \\
\text { oxygen } \\
\text { saturation } \\
\text { (percentage) }\end{array}$ & $\begin{array}{c}\text { Days } \\
\text { with } \\
\text { dissolved } \\
\text { oxygen } \\
\text { saturation } \\
\mathbf{< 0 \text { percent }} \\
\text { (percentage) }\end{array}$ \\
\hline $\begin{array}{c}\text { August } \\
2010\end{array}$ & 22 & 56 & 196 & 9 \\
$\begin{array}{c}\text { September } \\
2010\end{array}$ & 24 & 56 & 172 & 13 \\
July 2012 & 10 & 22 & 290 & 100 \\
August & 16 & 23 & 289 & 100 \\
2012 & & & & \\
\hline
\end{tabular}

on any days in September (table 16). During the 2012 study, the State $\mathrm{pH}$ standards were exceeded on 18 percent of days in July but were not exceeded on any days in August. The difference in average daily minimum and maximum $\mathrm{pH}$ values on any given day was relatively high, ranging from 1.4 to $2.2 \mathrm{pH}$ units.

\section{Groundwater Quality}

Groundwater nitrate concentrations varied greatly in the study reach during 2010, both spatially and over time (appendix 1). The groundwater nitrate concentrations were highest at the well transect 2 (middle-stream) right bank well (average $2.75 \mathrm{mg} / \mathrm{L}$ as $\mathrm{N}$ ), where groundwater was discharging to the stream (a gaining stream reach). In contrast, the well transect 2 (middle-stream) left bank well had nitrate concentrations below detection, where groundwater was also found to be discharging to the stream. Groundwater nitrate concentrations at the left bank well could have been diluted by infiltrating water in a nearby agricultural ditch along the stream in the study reach (fig. 2). Groundwater temperature data also indicate that groundwater was discharging at the well transect 2 (middle-stream) mid-stream well, where nitrate concentrations were above detection limits but not as high as concentrations in the right bank well. Groundwater nitrate concentrations generally were lower at the well transect 1 (upstream) and well transect 3 (downstream) wells, where the stream was found to be infiltrating to groundwater (a losing stream reach). The ratio of nitrate to total nitrogen concentrations in groundwater at all the wells varied substantially ( 0.04 to 0.97$)$; the highest ratios were at the well transect 2 (middle-stream) right bank well, where almost all the nitrogen was in the form of nitrate (0.94-0.97). Because the total organic nitrogen concentrations in groundwater were similar at all the wells, the wide range in ratios was due to the wide range in nitrate concentrations.

Table 16. Summary of exceedances of the State of Nevada pH water-quality standard at stream site East Fork Carson River near Muller Lane downstream transect (SDT), 2010 and 2012, East Fork Carson River, Carson Valley, west-central Nevada.

$[<$, less than; $>$, greater than $]$

\begin{tabular}{ccccc}
\hline $\begin{array}{c}\text { Month } \\
\text { and } \\
\text { year }\end{array}$ & $\begin{array}{c}\text { Total } \\
\text { days } \\
\text { monitored }\end{array}$ & $\begin{array}{c}\text { Average } \\
\text { daily } \\
\text { minimum } \\
\mathbf{p H}\end{array}$ & $\begin{array}{c}\text { Average } \\
\text { daily } \\
\text { maximum } \\
\mathbf{p H}\end{array}$ & $\begin{array}{c}\text { Days with } \\
\mathbf{p H}<6.5 \text { and } \\
\mathbf{p H}>\mathbf{9 . 0} \\
\text { (percentage) }\end{array}$ \\
\hline $\begin{array}{c}\text { August } \\
2010\end{array}$ & 22 & 7.3 & 9.1 & 36 \\
$\begin{array}{c}\text { September } \\
2010\end{array}$ & 24 & 7.4 & 8.8 & 0 \\
$\begin{array}{c}\text { July 2012 } \\
\text { August }\end{array}$ & 11 & 6.7 & 8.9 & 18 \\
2012 & 16 & 6.8 & 8.8 & 0 \\
\hline
\end{tabular}


Nitrate concentrations in groundwater relative to stream concentrations varied spatially and temporally. In July 2010, groundwater nitrate concentrations were generally lower than in the stream, but in October 2010, groundwater nitrate concentrations were generally higher than in the stream (appendix 1). For example, in July 2010, the nitrate concentrations in the stream were greater than those in groundwater at well transect 1 (upstream) wells and two wells at well transect 3 (downstream). At well transect 2 (middlestream), two of the wells had nitrate concentrations that were much greater than the nitrate concentration in the stream. As nitrate concentrations in the stream decreased at each stream site during the summer, by October, nitrate concentrations in groundwater were higher than the stream in two of three wells at well transect 1 (upstream), two of three wells at well transect 2 (middle-stream), and all wells at well transect 3 (downstream).

Groundwater orthophosphate concentrations in 2010 varied within the study reach, but for most wells, concentrations did not change over time (appendix 1). Highest groundwater orthophosphate concentrations were found at the well transect 3 (downstream) wells, where the stream was losing flow to groundwater. Three of four wells at well transect 3 (downstream) had orthophosphate concentrations greater than $0.1 \mathrm{mg} / \mathrm{L}$ as $\mathrm{P}$, which is the State stream water-quality standard for total phosphorus for the EFCR. The groundwater concentrations of orthophosphate at the well transect 2 (middle-stream) wells, where groundwater was discharging to the stream, were highest at the right bank well. The lowest orthophosphate concentrations were observed at the well transect 1 (upstream) wells. The ratio of orthophosphate to total phosphorus in groundwater at all wells ranged from 0.16 to 1.36 , with an average of 0.99 , indicating that most, if not all, of the total phosphorus in groundwater is orthophosphate.

Groundwater orthophosphate concentrations relative to stream concentrations also varied during summer 2010 (appendix 1). For example, groundwater orthophosphate concentrations in July were less than stream concentrations at well transect 1 (upstream), but at well transect 2 (middlestream) and well transect 3 (downstream), the groundwater orthophosphate concentrations were greater than stream concentrations. In September and October, groundwater orthophosphate concentrations at each well transect were greater than the stream concentrations.

To determine whether groundwater nutrient concentrations were constant or fluctuating throughout the day, groundwater samples were collected and field measurements made at well transect 2 (middle-stream) wells MRB6, MMS5, and MLB4 (fig. 5) every 2 hours over a 24-hour period on
September 8-9, 2010 (appendix 1). The well transect 2 (middle-stream) wells were chosen because the nitrate concentrations in groundwater were the highest compared to the other transect wells. No trends in nitrate, ammonia, total phosphorus, and orthophosphate were observed (fig. 16). The well transect 2 (middle-stream) right bank well (MRB6) had substantially higher nitrate concentrations than the other transect wells (figs. $16 A-C$ ), with an average nitrate concentration of $2.66 \mathrm{mg} / \mathrm{L}$ as N. The left bank well (MLB4; fig. 16C) had substantially higher total phosphorus concentrations than the other transect wells, with an average total phosphorus concentration of $0.142 \mathrm{mg} / \mathrm{L}$. Dissolved oxygen concentrations varied throughout the day at the three wells with no clear pattern, with concentrations ranging from 0.5 to $1.1 \mathrm{mg} / \mathrm{L}$ (fig. 16). A slight increase in dissolved chloride concentrations was observed at MRB6, located along the right bank of well transect 2 (middle-stream; fig. 17).

Groundwater concentrations of nitrate in 2012 generally were highest at the well transect 4 (upper), well transect 2 (middle-stream), and well transect 5 (lower) right bank and right bank floodplain wells (fig. 18; appendix 2). The concentration of nitrate at the right bank wells ranged from less than 0.01 to $3.29 \mathrm{mg} / \mathrm{L}$ as $\mathrm{N}$, with an average of $1.84 \mathrm{mg} / \mathrm{L}$ as $\mathrm{N}$. Relative to the average stream nitrate concentrations at SMT $(0.20 \mathrm{mg} / \mathrm{L}$ as $\mathrm{N})$, the average groundwater concentrations in the right bank and floodplain wells were nine times higher than in the stream. The ratio of nitrate to total nitrogen concentrations in groundwater varied substantially ( 0.08 to 0.97 ); the highest ratios were at right bank and floodplain wells, where most of the nitrogen was in the form of nitrate (range $0.02-0.97$, average 0.74 ).

Groundwater concentrations of orthophosphate during 2012 were highest at the well transect 4 (upper), well transect 2 (middle-stream), and well transect 5 (lower) right bank and right bank floodplain wells (fig. 18; appendix 2). Groundwater orthophosphate concentrations in the right bank and right bank floodplain wells ranged from 0.046 to $0.339 \mathrm{mg} / \mathrm{L}$ as $\mathrm{P}$, with an average of $0.122 \mathrm{mg} / \mathrm{L}$ as P. Relative to average stream orthophosphate concentrations at SMT $(0.01 \mathrm{mg} / \mathrm{L}$ as $\mathrm{P})$, the average groundwater orthophosphate concentrations in the right bank and floodplain wells are about 12 times the concentration of the stream. The ratio of orthophosphate to total phosphorus for the right bank and floodplain wells ranged from 0.13 to 1.14 , with an average of 0.99 , indicating that most, if not all, of the total phosphorus in groundwater was orthophosphate. Three of the right bank and floodplain wells had orthophosphate concentrations greater than $0.1 \mathrm{mg} / \mathrm{L}$ as $\mathrm{P}$, which is the State stream water-quality standard for total phosphorus in the EFCR. 
Well transect 2 (middle-stream) right bank observation well (MRB6)
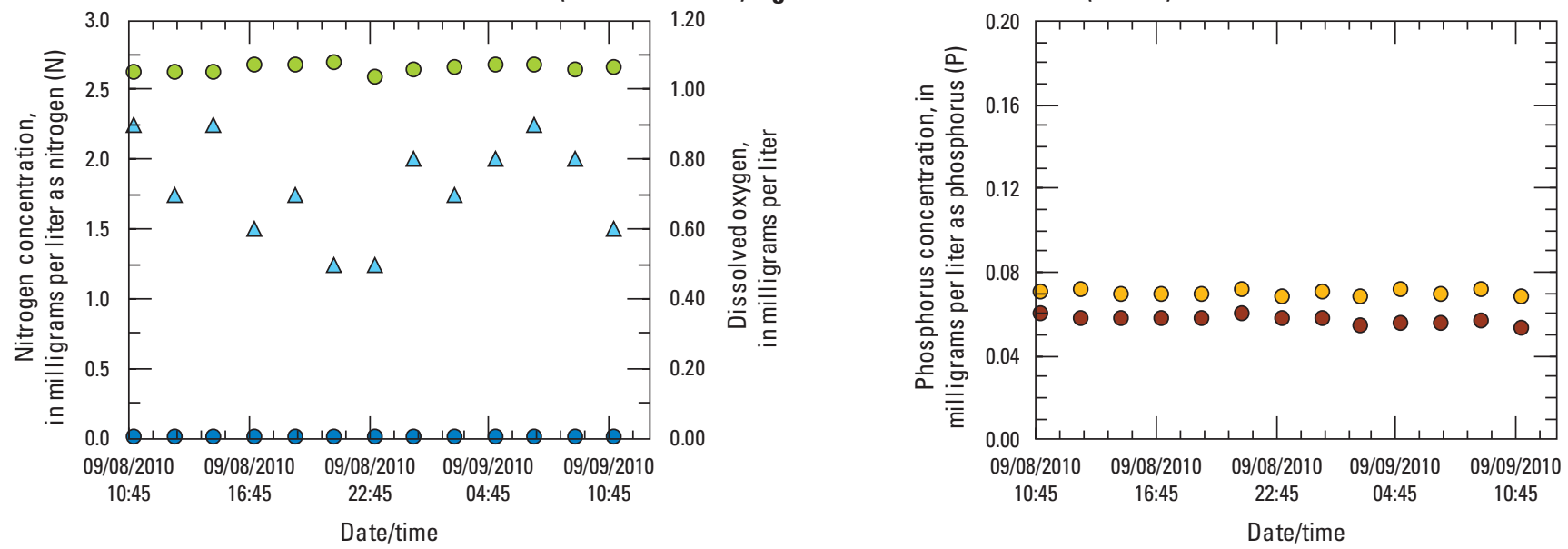

B
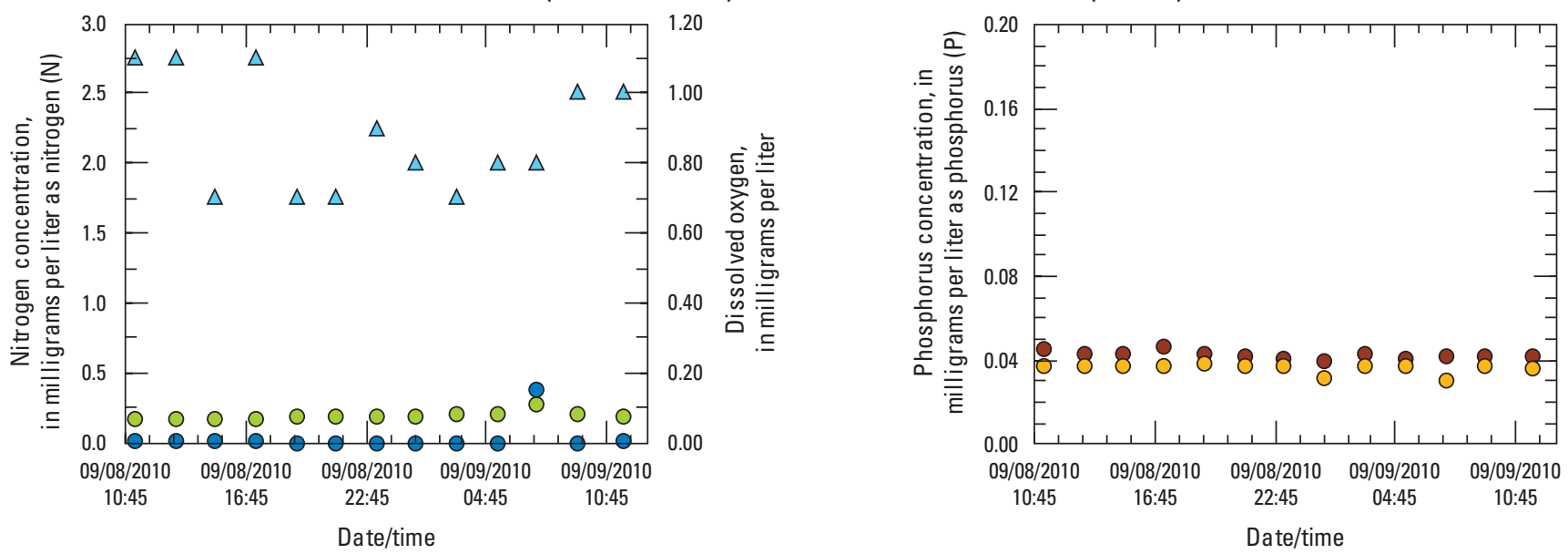

C

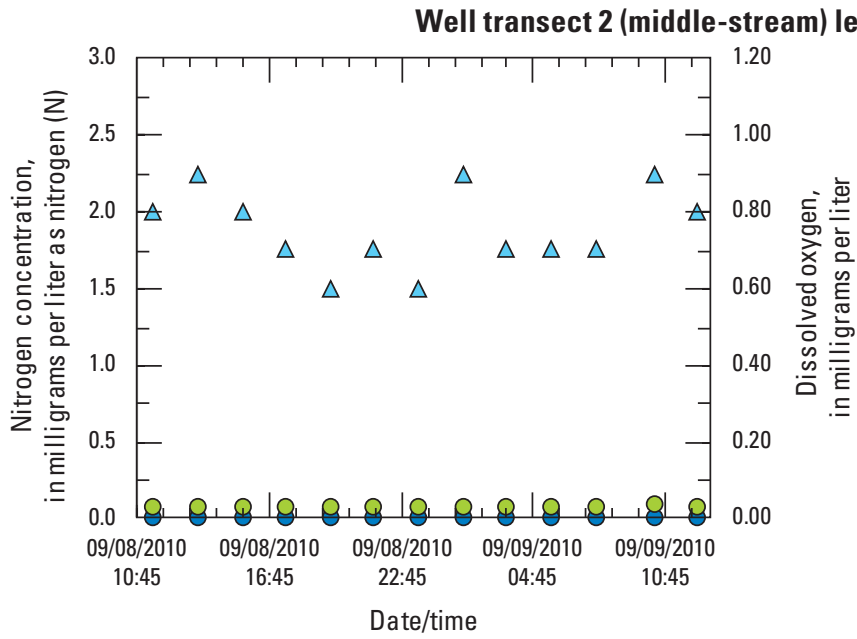

EXPLANATION
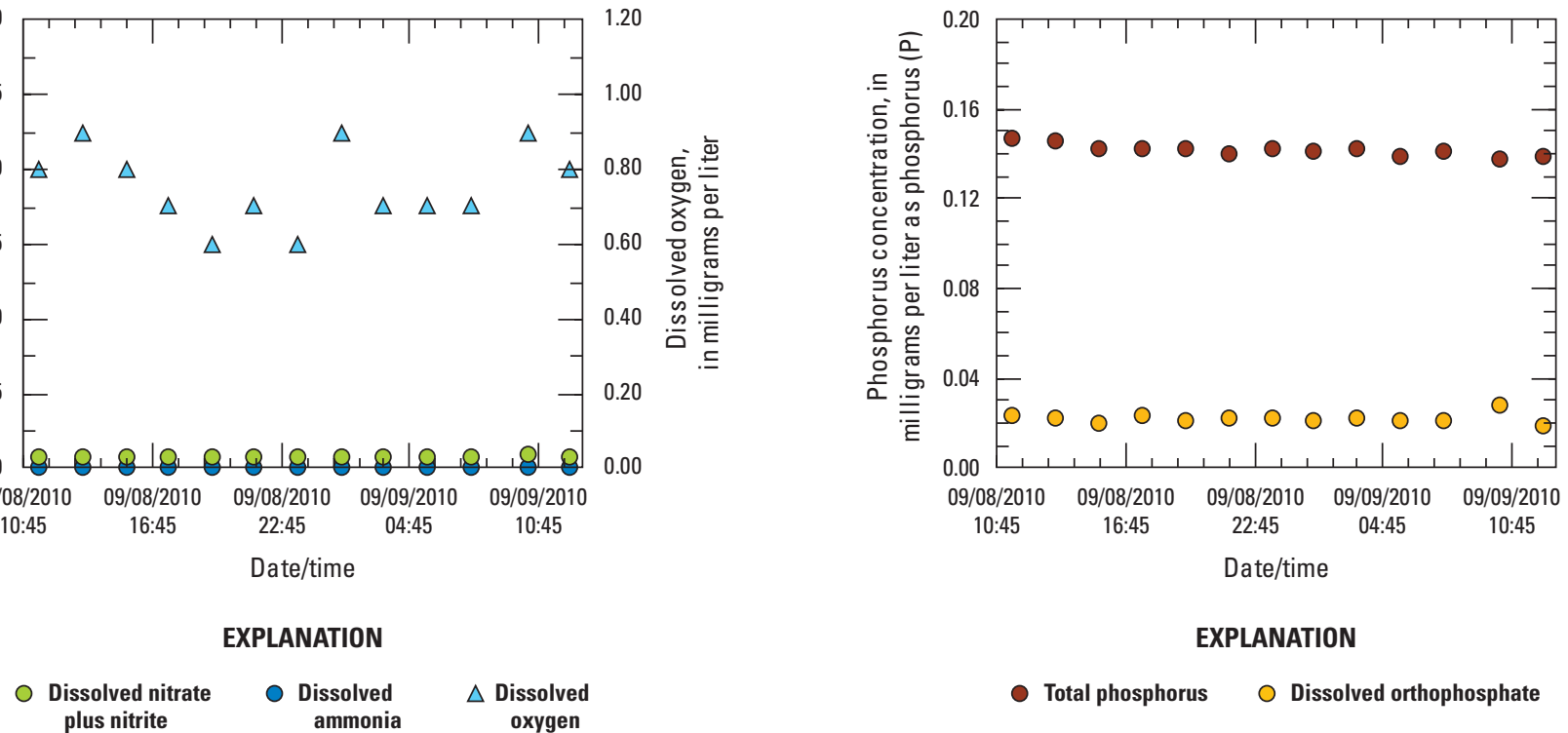

Dissolved
ammonia

$\triangle$ Dissolved oxygen

EXPLANATION

Figure 16. Nitrogen, phosphorus, and dissolved oxygen concentrations at the reconnaissance study well transect 2 (middle-stream) observation wells. $A$, right bank (MRB6); $B$, mid-stream (MMS5); and $C$, left bank (MLB4), September 8-9, 2010, East Fork Carson River, Carson Valley, west-central Nevada. 


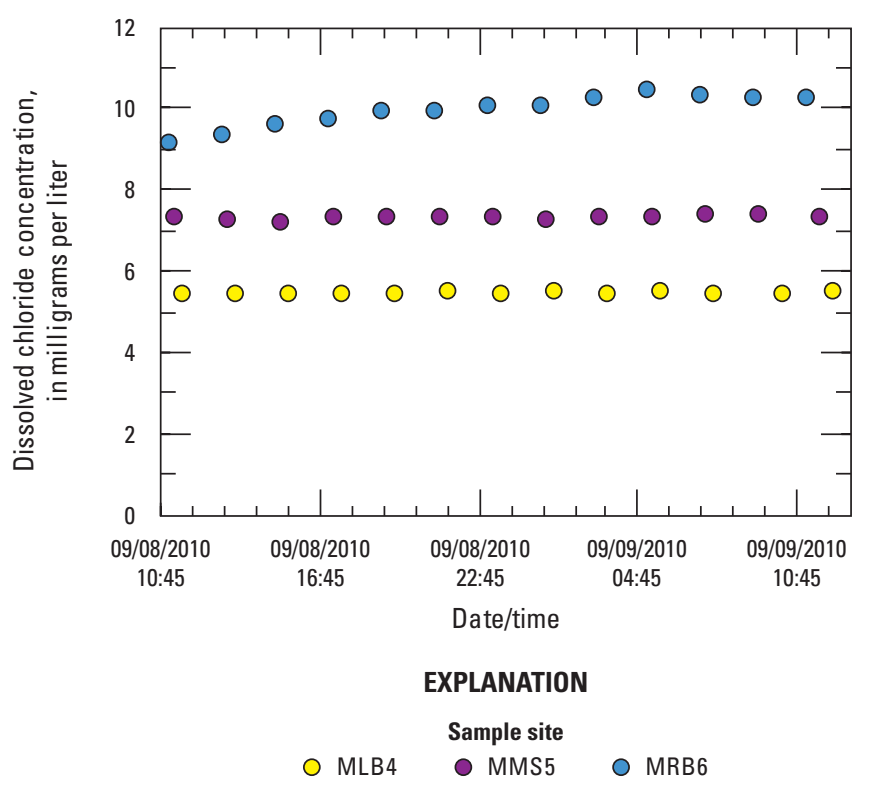

Figure 17. Chloride concentrations at the reconnaissance study well transect 2 (middle-stream) right bank (MRB6), mid-stream (MMS5), and left bank (MLB4) observation wells, September 8-9, 2010, East Fork Carson River, Carson Valley, west-central Nevada.
Comparison of groundwater nitrate concentrations in 2010 and 2012 at the well transects at and near SMT (2010 at well transect 2 [middle-stream] wells; 2012 at well transect 4 [upper], well transect 2 [middle-stream], and well transect 5 [lower]) indicate that the concentrations were similar (appendixes 1 and 2). The nitrate concentrations at the left bank wells in both 2010 and 2012 were below the detection limits. The nitrate concentrations at the mid-stream well in 2010 was lower than the concentrations at the midstream wells in 2012. The right bank and floodplain wells in 2012 generally had elevated nitrate concentrations similar to the right bank well at well transect 2 (middle-stream) in 2010. Groundwater orthophosphate concentrations at the well transect 2 (middle-stream) wells in 2010 and well transect 4 (upper), well transect 2 (middle-stream), and well transect 5 (lower) wells in 2012 were similar except higher orthophosphate concentrations in the right bank floodplain wells in 2012 than in the well transect 2 (middle-stream) right bank well in 2010 . 

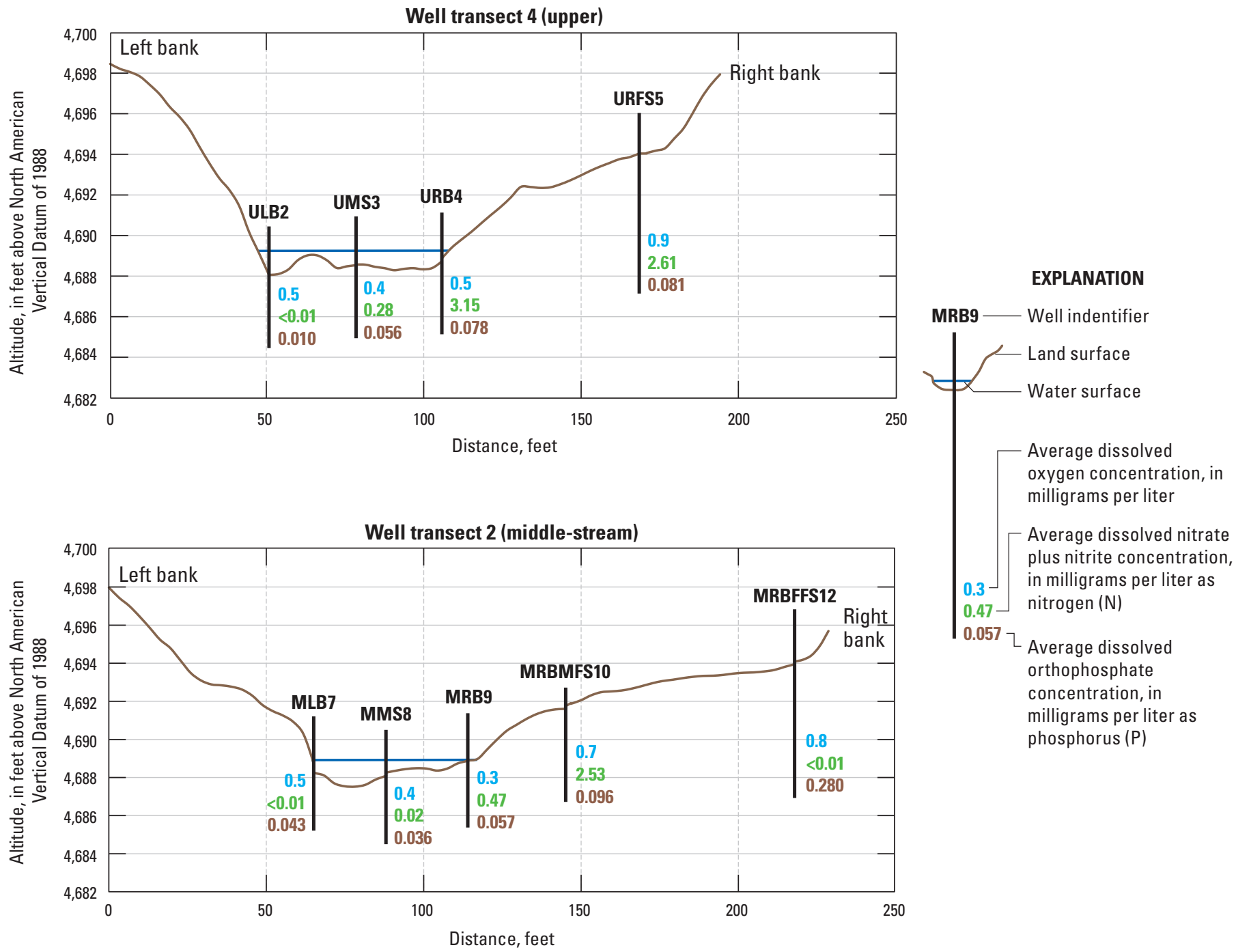

milligrams per liter as phosphorus $(\mathrm{P})$

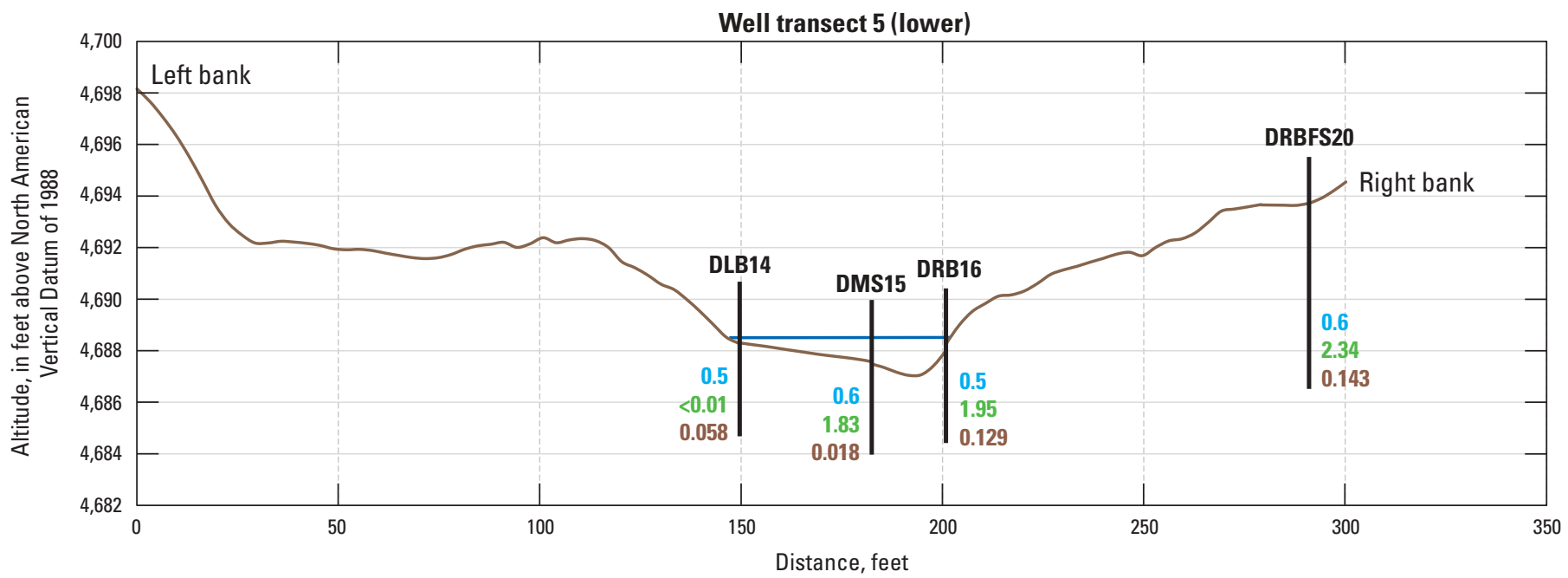

Figure 18. Average concentrations of dissolved oxygen, dissolved nitrate plus nitrite, and dissolved orthophosphate in observation wells at well transect 4 (upper), well transect 2 (middle-stream), and well transect 5 (lower), summer 2012, East Fork Carson River, Carson Valley, west-central Nevada. 


\section{Algal Conditions}

The amount of algal biomass depends on several stream characteristics. Given adequate nutrient concentrations in the stream, some of the more important potential factors that influence the amount of algal biomass include water velocity, water temperature, light availability, time since last scour event, and grazing by benthic invertebrates and herbivorous fish (Wise and others, 2009). Periphyton, also called periphytic algae, or benthic algae, are attached to rocks and were the most common form of algae found in the study reach.

Algal cover estimates were 25 to 50 percent at the three stream sites in July 2010. In September 2010, the percent cover ranged from 75 to 100 percent at the three stream sites, which exceeds the cover threshold of 50 percent (table 17) and indicates nuisance conditions. The highest periphyton biomass level measured during the summer of 2010 was at SMT on September 9, 2010, where chl- $a$ levels exceeded the impairment threshold of 150 milligrams of chl- $a$ per square meter (mg chl- $a / \mathrm{m}^{2}$; table 17; fig. 19), indicating nuisance levels of periphyton. The other five samples collected at SUT, SMT, and SDT in July and September 2010 were at levels less than the chl- $a$ threshold, indicating periphyton biomass did not reach nuisance levels. The periphyton biomass levels were higher at all stream sites in September than in July of 2010 based on both the algal cover estimates and the chl- $a$ levels. Moreover, based on the trophic classification scheme suggested by Dodds and others (1988), the study reach was characterized as mesotrophic to eutrophic during summer 2010 (table 18).

The autotrophic index (AFDM:chl- $a$ ratios) varied from 221 at SMT in September 2010 to 860 at SUT in July 2010 (table 17). Autotrophic indices above 400 were present at
SUT (860) and SMT (460) in July 2010, indicating organic enrichment of the stream during the time of sampling. The autotrophic index was not exceeded at the three stream sites in September 2010. The average autotrophic index was the lowest at SMT (248 in 2010). Additional samples are needed to assess whether organic pollution inputs to the stream is the cause of the high autotrophic index values or if the cause is upstream sources or detritus.

Elevated periphyton biomass levels were observed in the study reach at all three stream sites during summer 2012 (table 17; fig. 19). Moreover, average periphyton biomass levels were higher at all stream sites in 2012 than in 2010. Higher stream temperatures and lower streamflows during summer 2012 likely contributed to the higher periphytic biomass in 2012 than in 2010. Algae cover exceeded the threshold of 50 percent at all three stream sites in 2012 (table 17), indicating the presence of nuisance conditions. The chl- $a$ levels exceeded the impairment threshold of $150 \mathrm{mg}$ chl $-a / \mathrm{m}^{2}$ in July at all three stream sites, and again in August and September at SUT and SMT, indicating nuisance algae conditions (fig. 19; table 17). The study reach was characterized as eutrophic in summer 2012 (table 18; fig. 20; Dodds and others, 1988), with greater primary productivity occurring than during the mesotrophic-eutrophic conditions observed in 2010.

The autotrophic index (AFDM:chl- $a$ ratios) varied from 190 in August 2012 at SMT to 887 in July 2012 at SUT (table 17; fig. 20). The average autotrophic index was the lowest at SMT (372). The highest autotrophic indices in the study reach during summer 2012 often exceeded values greater than 400 (table 17), indicating organic pollution inputs to the stream. 
Table 17. Chlorophyll a, algal biomass, algal biomass to chlorophyll a ratio, and percent algal cover for stream sites, East Fork Carson River, 2010 and 2012, Carson Valley, westcentral Nevada.

[Site locations are shown in figures 5 and 6. Shading indicates value above nuisance threshold level. Abbreviations: E, estimate; g/m², gram per square meter; $\mathrm{mg} / \mathrm{m}^{2}$, milligram per square meter; $\mathrm{mm} / \mathrm{dd} / \mathrm{yyyy}$, month/day/year; SDT, East Fork Carson River near Muller Lane downstream transect; SMT, East Fork Carson River near Muller Lane middle-stream transect; SUT, East Fork Carson River near Muller Lane upstream transect; \%, percent; - , no data]

\begin{tabular}{|c|c|c|c|c|c|c|c|c|c|c|c|c|}
\hline \multirow[b]{2}{*}{$\begin{array}{c}\text { Date } \\
\text { (mm/dd/yyyy) }\end{array}$} & \multicolumn{4}{|c|}{ SUT } & \multicolumn{4}{|c|}{ SMT } & \multicolumn{4}{|c|}{ SDT } \\
\hline & $\begin{array}{c}\text { Chlorophyll } a \\
\left(\mathrm{mg} / \mathrm{m}^{2}\right)\end{array}$ & $\begin{array}{c}\text { Biomass, } \\
\text { ash free } \\
\text { dry mass } \\
\left(\mathrm{g} / \mathrm{m}^{2}\right)\end{array}$ & $\begin{array}{c}\text { Ash free } \\
\text { dry mass/ } \\
\text { chlorophyll a } \\
\text { ratio }\end{array}$ & $\begin{array}{c}\text { Percent } \\
\text { cover } \\
\text { (percentage) }\end{array}$ & $\begin{array}{c}\text { Chlorophyll a } \\
\left(\mathrm{mg} / \mathrm{m}^{2}\right)\end{array}$ & $\begin{array}{c}\text { Biomass, } \\
\text { ash free } \\
\text { dry mass } \\
\left(\mathrm{g} / \mathrm{m}^{2}\right)\end{array}$ & $\begin{array}{c}\text { Ash free } \\
\text { dry mass/ } \\
\text { chlorophyll a } \\
\text { ratio }\end{array}$ & $\begin{array}{c}\text { Percent } \\
\text { cover } \\
\text { (percentage) }\end{array}$ & $\begin{array}{c}\text { Chlorophyll } a \\
\left(\mathrm{mg} / \mathrm{m}^{2}\right)\end{array}$ & $\begin{array}{c}\text { Biomass, } \\
\text { ash free } \\
\text { dry mass } \\
\left(\mathrm{g} / \mathrm{m}^{2}\right)\end{array}$ & $\begin{array}{c}\text { Ash free } \\
\text { dry mass/ } \\
\text { chlorophyll a } \\
\text { ratio }\end{array}$ & $\begin{array}{c}\text { Percent } \\
\text { cover } \\
\text { (percentage) }\end{array}$ \\
\hline 07/29/2010 & 15.7 & 13.5 & 860 & $25-50$ & 37 & 17.2 & 465 & $25-50$ & 76.9 & 19.8 & 257 & $25-50$ \\
\hline 09/09/2010 & E67 & 20.7 & E309 & $75-100$ & 307 & 67.9 & 221 & $75-100$ & 102 & 37.4 & 367 & $75-100$ \\
\hline $\begin{array}{l}\text { 09/09/2010 } \\
\text { Duplicate }\end{array}$ & - & - & - & - & - & - & - & - & E105 & 36.2 & E345 & - \\
\hline Average & 41.4 & 17.1 & 414 & - & 172 & 42.6 & 248 & - & 89.5 & 28.6 & 320 & - \\
\hline $07 / 23 / 2012$ & 205 & 181.9 & 887 & $75-100$ & 283 & 126.5 & 447 & $75-100$ & 409 & 182.1 & 445 & $75-100$ \\
\hline 08/27/2012 & 165 & 75.4 & 457 & $75-100$ & 181 & 34.4 & 190 & $75-100$ & E71.4 & 53.8 & E753 & $75-100$ \\
\hline $\begin{array}{l}\text { 08/27/2012 } \\
\text { Duplicate }\end{array}$ & 211 & 75.4 & 357 & - & 135 & 48.9 & 362 & - & E84.6 & 53.5 & E633 & - \\
\hline 09/20/2012 & 349 & 115 & 330 & $75-100$ & 280 & 115.6 & 413 & $75-100$ & E45.1 & 19.6 & E435 & $75-100$ \\
\hline $\begin{array}{c}\text { 09/20/2012 } \\
\text { Duplicate }\end{array}$ & 381 & 101.7 & 267 & - & 362 & 113 & 312 & - & E40.3 & 16.6 & E412 & - \\
\hline Average & 240 & 124.1 & 517 & - & 248 & 92.2 & 372 & - & 175.2 & 85.2 & 486 & - \\
\hline
\end{tabular}




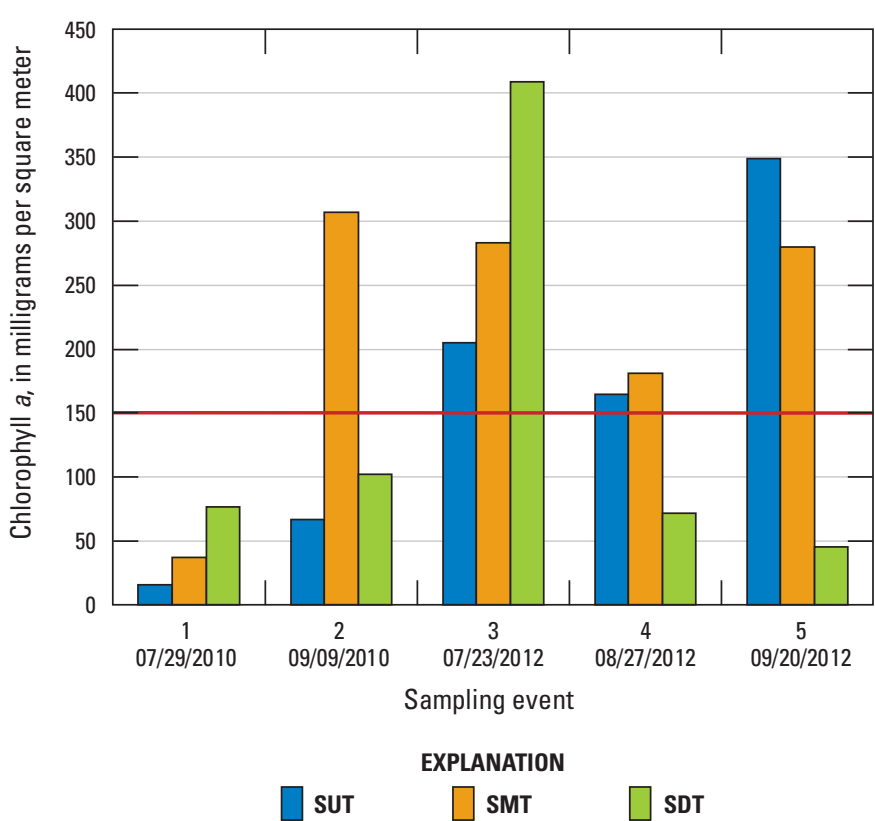

Figure 19. Chlorophyll a concentrations from five sampling events at stream sites in 2010 and 2012, East Fork Carson River, Carson Valley, west-central Nevada. Stream sites are East Fork Carson River near Muller Lane upstream transect (SUT), East Fork Carson River near Muller Lane middle-stream transect (SMT), and East Fork Carson River near Muller Lane downstream transect (SDT). The dashed red line is the impairment threshold from Welch and Jacoby (2004) and Suplee and others (2009).

Table 18. Trophic status for stream sites, 2010 and 2012, based upon mean and maximum chlorophyll a levels, East Fork Carson River, Carson Valley, west-central Nevada.

[Site locations are shown in figures 5 and 6 . Abbreviations: $\mathrm{mg} / \mathrm{m}^{2}$, milligram per square meter; SDT, East Fork Carson River near Muller Lane downstream transect; SMT, East Fork Carson River near Muller Lane middle-stream transect; SUT, East Fork Carson River near Muller Lane upstream transect]

\begin{tabular}{lcccc}
\hline Site & $\begin{array}{c}\text { Mean } \\
\text { chlorophyll } \boldsymbol{a} \\
\left(\mathbf{m g} / \mathbf{m}^{2}\right)\end{array}$ & $\begin{array}{c}\text { Trophic } \\
\text { state based } \\
\text { on mean } \\
\text { chlorophyll } \mathbf{a}\end{array}$ & $\begin{array}{c}\text { Maximum } \\
\text { chlorophyll } \boldsymbol{a} \\
\left(\mathbf{m g} / \mathbf{m}^{2}\right)\end{array}$ & $\begin{array}{c}\text { Trophic } \\
\text { state based } \\
\text { on maximum } \\
\text { chlorophyll } \mathbf{a}\end{array}$ \\
\hline SUT & 41.4 & Mesotrophic & 67 & Mesotrophic \\
SMT & 172 & Eutrophic & 307 & Eutrophic \\
SDT & 89.5 & Eutrophic & 102 & Mesotrophic \\
\hline & \multicolumn{5}{c}{2012} & & \\
\hline SUT & 240 & Eutrophic & 349 & Eutrophic \\
SMT & 248 & Eutrophic & 283 & Eutrophic \\
SDT & 175.2 & Eutrophic & 409 & Eutrophic \\
\hline
\end{tabular}

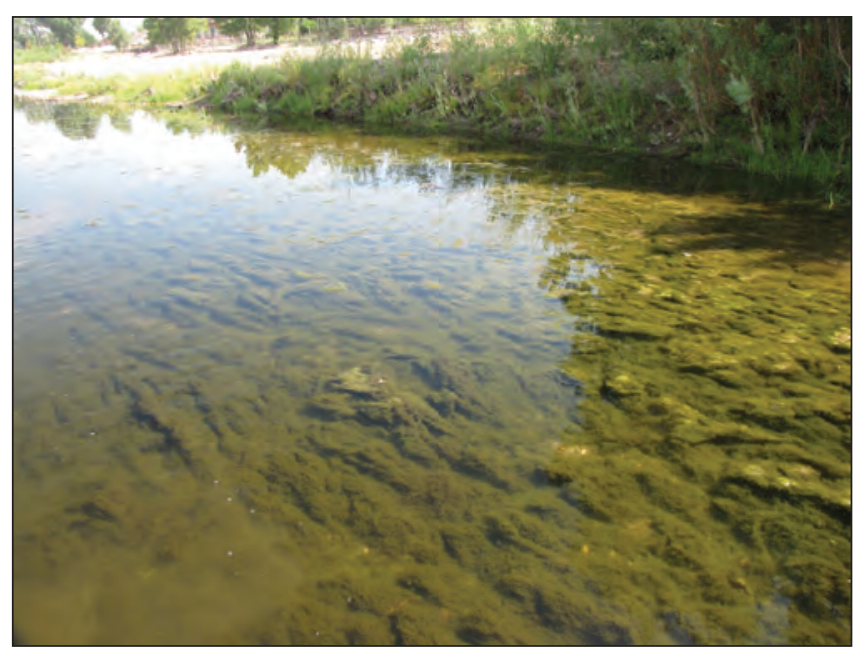

Figure 20. High algal biomass at stream site East Fork Carson River near Muller Lane middle-stream transect (SMT), July 23, 2012, East Fork Carson River, Carson Valley, west-central Nevada. Photograph by R. Pahl.

\section{Sources of Nitrate and Denitrification in Groundwater}

Several potential sources of nitrate in groundwater are present in areas upstream of and adjacent to SMT and well transect 2 (middle-stream). Sources of nitrate in groundwater and the process of denitrification were assessed by several methods using data collected in 2012 - organic wastewater compounds, nitrogen and oxygen isotopes, and dissolved gases. Organic wastewater compounds were evaluated to confirm the occurrence and general movement of anthropogenic compounds in groundwater from an urban area adjacent to SMT and well transect 2 (middle-stream). Nitrogen and oxygen isotopes also were evaluated to delineate sources of nitrate in groundwater and to assess the degree to which denitrification has occurred. Dissolved gases were evaluated as a secondary method to help confirm whether denitrification was occurring in shallow groundwater. 


\section{Sources of Nitrate}

Treated and untreated wastewater, both domestic and industrial, are a common source of nitrate and of some anthropogenic organic compounds in surface water and groundwater. Depending on the level of wastewater treatment, these constituents may not be entirely removed during the treatment process (Lee and others, 2004). Because no treated or untreated wastewater is discharged to the EFCR, the direct discharge of treated or untreated wastewater was not considered a source of nitrate in groundwater adjacent to SMT and well transect 2 (middle-stream). However, leakage from wastewater discharge lines serving urban areas often are considered sources of nitrate or anthropogenic compounds in groundwater (Mahler and others, 2011). In addition to wastewater, common sources for nitrate and organic compounds in groundwater include agricultural, municipal, and domestic applications of fertilizers and pesticides. Organic compounds often found in wastewater were evaluated, along with nitrogen and oxygen isotopes, to confirm the presence of anthropogenic compounds in groundwater and attempt to identify potential sources of nitrate.

\section{Evidence from Detection of Organic Wastewater Compounds}

Fifty-nine organic compounds that occur frequently in wastewater were evaluated in samples from select observation wells (table 1). Organic wastewater compounds include, but are not limited to, detergent metabolites, fragrances and flavors, pesticides and degradates, industrial compounds, disinfectants and byproducts, polycyclic aromatic hydrocarbons (PAHs), flame retardants and plasticizers, plant sterols, animal sterols, and nonprescription pharmaceuticals and metabolites. Specific organic wastewater compounds included in analyzed groundwater samples, their uses, and laboratory reporting levels are summarized in table 4 .

Concentrations of organic wastewater compounds typically are very low in groundwater (Barnes and others, 2008; Mahler and others, 2011); therefore, evaluation of organic wastewater compounds in samples from wells DRBFS20, MRBFFS12, MRBMFS10, and URBFS5 focused on whether compounds were detected rather than the concentration.

The sample from well DRBFS20 contained two detections of organic wastewater compounds: $N, N$-Diethyl$m$-toluamide (also known as DEET), an insecticide, and beta-sitosterol, a natural plant ester added to medicines and food. However, concentrations for these compounds in environmental samples were at or lower than concentrations in quality control field blank samples, indicating potential contamination of the groundwater sample at this low concentration; therefore, detection in groundwater is suspect.

The sample from well MRBFFS12 contained seven detections of organic wastewater compounds, the highest number of detections for the four wells sampled. The organic compound DEET was detected in this sample at a concentration well above the laboratory reporting level (LRL) and the concentration observed in the field blank, indicating a positive detection at this well. Tris(dichloroisopropyl) phosphate and tris(2-butoxyethyl) phosphate, which are both used in flame retardants, were detected at concentrations equal to or above the long-term method detection limit (LT-MDL) but below the LRL. Prometon, tris(2-chloroethyl) phosphate, beta-stigmastanol, and cholesterol were detected at concentrations below the LT-MDL. Beta-stigmastanol also was found in the field blank at a concentration below the LT-MDL similar to the environmental sample; therefore, detection of this compound in groundwater is suspect.

Downgradient from well MRBFFS12, the sample from well MRBMFS10 contained one detection of the organic wastewater compound prometon at a concentration below the LT-MDL. The sample and replicate from URBFS5 had no detections of organic wastewater compounds.

Although the concentrations of organic wastewater compounds and pesticides were mostly below method reporting and detection levels, there were a total of seven detections of organic wastewater compounds in the groundwater samples, with two of the four samples having at least one detection. The presence of the same compound in more than one sample, and in some cases the presence of compounds at concentrations above the LT-MDL, indicates that some anthropogenic influence is affecting the shallow groundwater near the stream. The presence of the insecticide DEET and flame retardants in groundwater samples may be from small leaks in sewer lines, residential land uses nearby, or from stormwater runoff from the outlet pipe near MRBFFS12 (fig. 3) that could infiltrate into the shallow groundwater. Prometon is an herbicide used to control the emergence of annual and perennial broad-leaf weed, brush, and grass and is commonly used in non-cropping situations, such as domestic lawns and road right of ways. Irrigation of lawns may mobilize residual prometon into the shallow groundwater. In addition, background concentrations of nitrate in Douglas County groundwater were estimated to be less than $1 \mathrm{mg} / \mathrm{L}$ (Rosen, 2003), indicating that concentrations observed in the right bank wells at well transect 4 (upper), well transect 2 (middle-stream), and well transect 5 (lower) were caused by anthropogenic activities. 


\section{Denitrification}

Denitrification can occur when DO concentration is less than $0.5 \mathrm{mg} / \mathrm{L}$, but ideal conditions for denitrification are below $0.2 \mathrm{mg} / \mathrm{L}$ (van Haandel and van der Lubbe, 2007; Mahler and others, 2011). The range of DO measured in groundwater at the well transect 2 (middle-stream) wells during 2010 indicates that DO concentrations were near the threshold for when denitrification occurs. Nitrogen and oxygen isotopes and dissolved gases in groundwater were collected in 2012 and evaluated to confirm that denitrification was occurring in groundwater in the vicinity of SMT and the three 2012 well transects.

\section{Evidence from Nitrogen and Oxygen Isotopes}

Nitrogen and oxygen isotope analyses were completed for eight groundwater samples collected during late September 2012 (appendix 2). Ranges of $\delta^{15} \mathrm{~N}_{\text {nitrate }}$ and $\delta^{18} \mathrm{O}_{\text {nitrate }}$ values of nitrate sources reported in the literature are shown in figure 21. Potential sources of nitrate in groundwater near EFCR shown in figure 21 include atmospheric deposition, chemical fertilizer, soil-derived nitrate, and human/animal waste (such as manure, leaking underground sewage pipes, and septic waste). Values of $\delta^{15} \mathrm{~N}_{\text {nitrate }}$ in groundwater samples ranged from $+13.66 \%$ o to $+30.36 \%$; $\delta^{18} \mathrm{O}_{\text {nitrate }}$ values in these samples ranged from $+5.33 \%$ to $+12.88 \%$ o.

A plot of $\delta^{18} \mathrm{O}_{\text {nitrate }}$ as a function of $\delta^{15} \mathrm{~N}_{\text {nitrate }}$ for the samples shows an increase in $\delta^{18} \mathrm{O}_{\text {nitrate }}$ as $\delta^{15} \mathrm{~N}_{\text {nitrate }}$ increases with a slope of $0.35\left(R^{2}=0.87\right.$; fig. 21$)$. Denitrification causes the $\delta^{15} \mathrm{~N}$ and $\delta^{18} \mathrm{O}$ of the residual nitrate to increase. A characteristic signature of denitrification is a slope of 0.48 when $\delta^{15} \mathrm{~N}_{\text {nitrate }}$ is plotted against $\delta^{18} \mathrm{O}_{\text {nitrate }}$ (Kendall,
1998; Kendall and others, 2007). The slope of 0.35 for the study data may indicate that denitrification was occurring in groundwater near the EFCR. Denitrification also causes the $\delta^{15} \mathrm{~N}$ of the residual nitrate to increase exponentially as nitrate concentrations decrease (Kendall and others, 2007). Kendall and others (2007) give an example of how denitrification of fertilizer nitrate with a $\delta^{15} \mathrm{~N}$ value of $+0 \%$ o can result in residual nitrate with much higher values $(+15 \%$ o to $+30 \%$ ) that are within the range of values expected for nitrate with the source of manure or septic tanks. Thus, denitrification can mask the original source of the nitrate and make source identification difficult.

Denitrification can cause an increase or enrichment in $\delta^{18} \mathrm{O}_{\text {nitrate }}$ and $\delta^{15} \mathrm{~N}_{\text {nitrate }}$ as the residual nitrate decreases (fig. 22). At well transect 5 (lower), for example, nitrate concentrations decreased as $\delta^{15} \mathrm{~N}_{\text {nitrate }}$ increased in the direction of groundwater flow to the EFCR (indicated by the arrows in fig. 22), from DRBFS20 to DRB16 to DS15. Similarly, at well transect 2 (middle-stream), nitrate concentrations decreased as $\delta^{15} \mathrm{~N}_{\text {nitrate }}$ increased from MRBMFS10 to MRB9. However, at well transect 4 (upper), nitrate increased and $\delta^{15} \mathrm{~N}_{\text {nitrate }}$ decreased in the direction of groundwater flow, from URBFS5 to URB4, and then farther downgradient, nitrate decreased substantially and $\delta^{15} \mathrm{~N}_{\text {nitrate }}$ increased slightly from URB4 to UMS3. These data provide strong evidence that denitrification is an important process as groundwater moves towards the stream. However, although nitrate concentrations decrease from upgradient wells to wells near the stream, concentrations are still relatively high (near $1 \mathrm{mg} / \mathrm{L}$ ), indicating that denitrification is not complete. Assuming that the loss of nitrate is completely from denitrification, nitrate losses in well transect 2 (middle-stream) and well transect 5 (lower) may be between 55 and 73 percent based on reduction of nitrate concentration across the well transects (fig. 22).

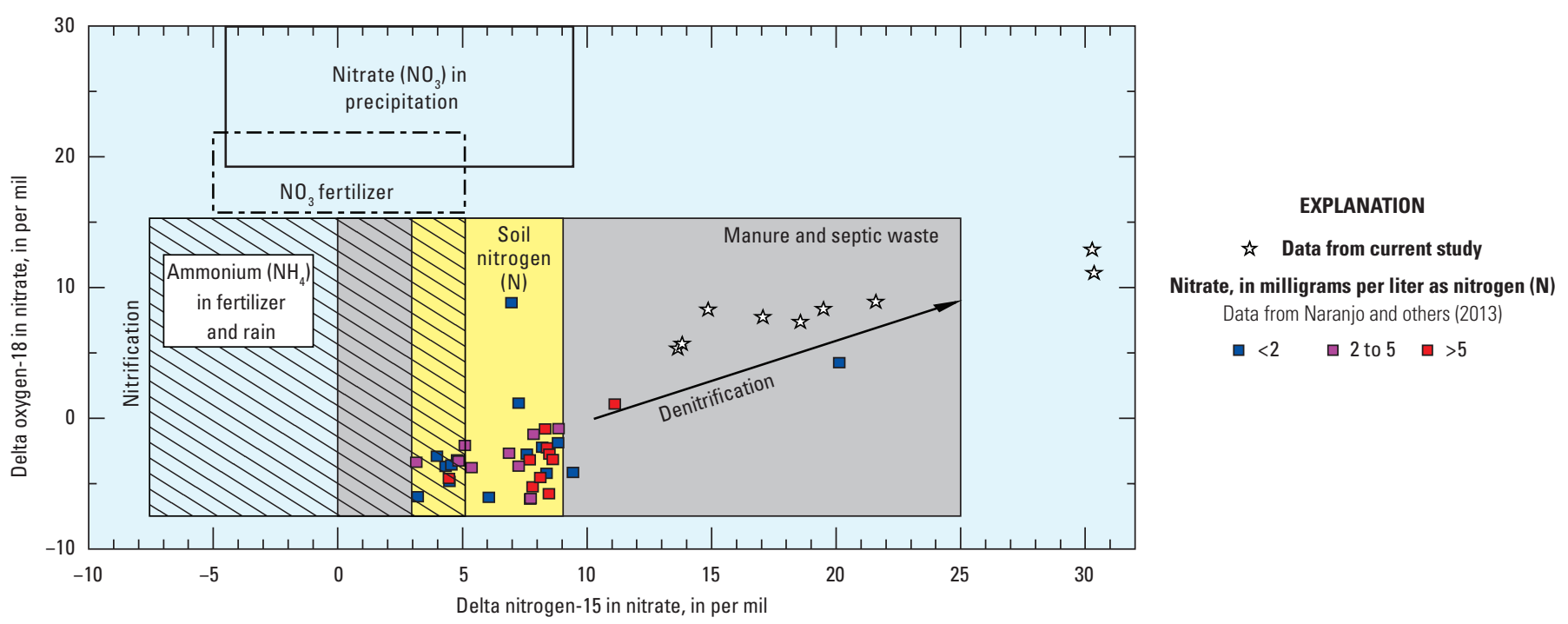

Figure 21. $\delta^{15} \mathrm{~N}$ and $\delta^{18} 0$ compositions of nitrate in groundwater samples collected from select wells in Douglas County, Carson Valley, west-central Nevada. 


\section{Evidence from Dissolved Gases}

Biogeochemical reactions such as denitrification in the groundwater system were evaluated using dissolved gases (Lindsey and others, 2003; Harte, 2013). Dissolved-gas measurements were made during 2012 for oxygen, methane, carbon dioxide, argon, and nitrogen at observation wells along well transect 4 (upper), well transect 2 (middle-stream), and well transect 5 (lower; table 1; fig. 6).

At all three well transects, DO gas concentrations analyzed by the laboratory from collected groundwater samples were low $(0.2 \mathrm{mg} / \mathrm{L})$, although DO field measurements were slightly higher $(0.3$ to $0.8 \mathrm{mg} / \mathrm{L})$ and differences likely due to the accuracy of field DO meters. Low DO concentrations can be an indicator of reducing groundwater conditions, and this is supported by the presence of methane gas at two well transect 4 (upper) wells (ULB2 and UMS3) and all well transect 2 (middle-stream) wells sampled. Although concentrations of methane gas were low $(<0.041 \mathrm{mg} / \mathrm{L})$ when present, any methanogenic activity is an indication of anaerobic conditions (Parker, 1994). As a result, field and laboratory DO concentrations and methane gas data indicate that reducing conditions that promote denitrification exist along well transect 2 (middle-stream) and at well transect 4 (upper) left bank to the middle of the stream.

Dissolved-gas concentrations also were used to estimate excess $\mathrm{N}_{2}$ gas as an additional method to confirm denitrification (Lindsey and others, 2013); however, excess $\mathrm{N}_{2}$ gas was not detected at any sampled locations when two different recharge elevations $(4,700$ and $8,500 \mathrm{ft})$ were evaluated (appendix 4). The mean annual air temperatures in the vicinity of Carson Valley ranged from 6.2 to $11.3{ }^{\circ} \mathrm{C}$, which generally agreed with the calculated recharge temperatures at $8,500 \mathrm{ft}\left(5.0\right.$ to $12.0{ }^{\circ} \mathrm{C}$, average $\left.9.2^{\circ} \mathrm{C}\right)$ and at $4,700 \mathrm{ft}\left(10.5\right.$ to $18.2{ }^{\circ} \mathrm{C}$, average $\left.15.1{ }^{\circ} \mathrm{C}\right)$, indicating that the calculated recharge temperatures were not biased high owing to denitrification and did not need to be adjusted. The mean annual air temperature for Fish Springs meteorological station, on the southeast side of Carson Valley (\#MFISN2; $5,229 \mathrm{ft}$ elevation; fig. 1 ), was $11.3{ }^{\circ} \mathrm{C}(2007-14)$; the mean annual air temperature for the Minden meteorological station (\#265191; 4,709 ft elevation; fig. 1), which is a similar elevation as the wells, was $9.7^{\circ} \mathrm{C}(1906-2012)$; and the mean annual air temperature for Dagget Pass meteorological station (\#262119; 7,334 ft elevation; fig. 1), at a higher elevation in the Carson Range (but not in the recharge area), was $6.2^{\circ} \mathrm{C}$ (1988-2012). Although a lack of excess $\mathrm{N}_{2}$ gas indicates that denitrification was not occurring, this method of assessing denitrification generally is less conclusive than results from evaluating changes in nitrate, isotopes, DO, and methane gas in groundwater because of the uncertainties in the assumed recharge conditions (altitude, temperature, and excess air) affecting the estimation of excess $\mathrm{N}_{2}$ (Puckett and others, 2008). For example, the detection of excess $\mathrm{N}_{2}$ gas could have been affected by degassing during sample collection caused by the use of a peristaltic pump to collect samples (Wilde and others, 2004, p. 26). If a water sample behaves like an open system by degassing or re-equilibrating with air, the components of nitrogen gas may be difficult to resolve (Lindsey and others, 2003). Additionally, where denitrification occurs in the unsaturated zone or in the saturated zone near the water table, denitrification can be undetected or underestimated (Lindsey and others, 2003).

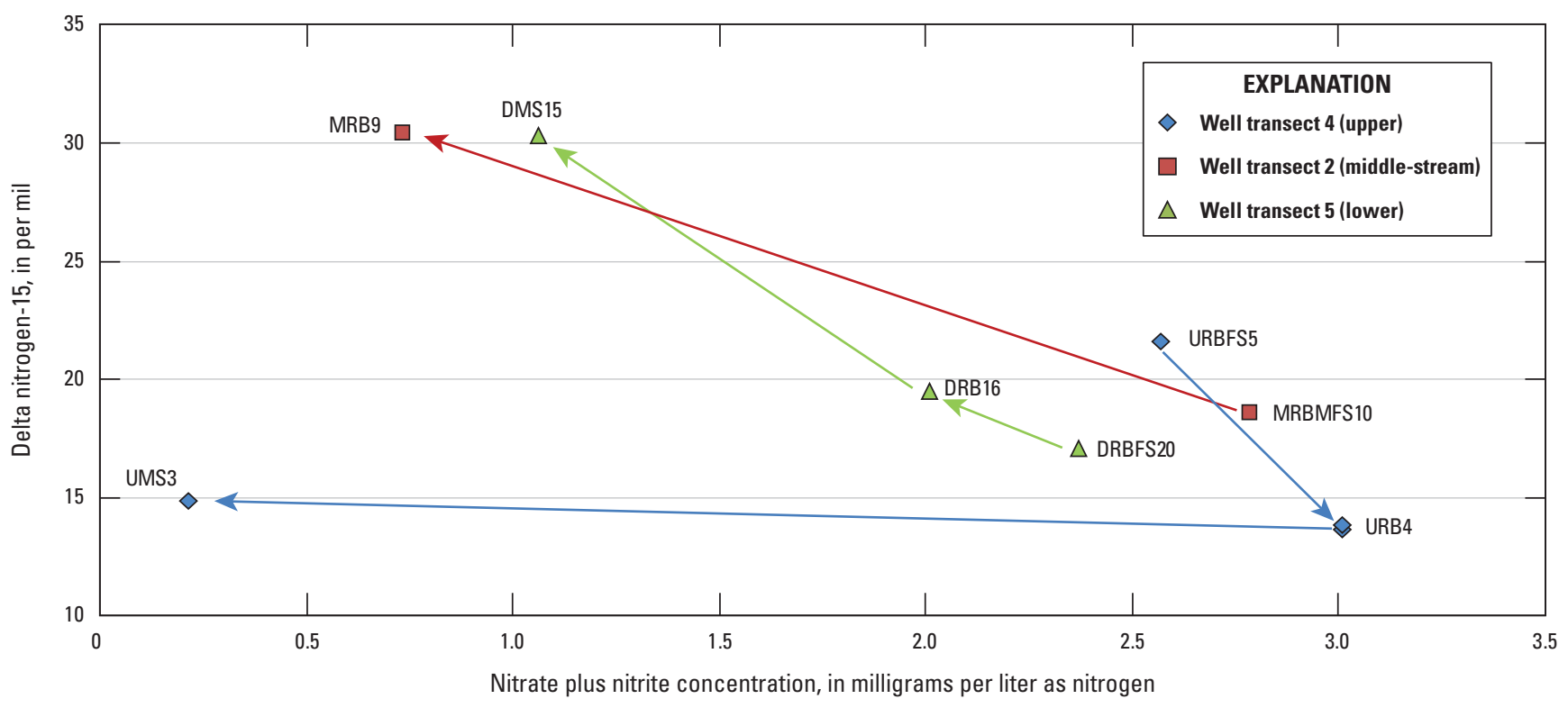

Figure 22. $\quad \delta^{15} \mathrm{~N}_{\text {nitrate }}$ and nitrate plus nitrite concentrations in groundwater samples collected from select groundwater wells at well transect 2 (middle-stream), well transect 4 (upper), and well transect 5 (lower), 2012, East Fork Carson River, Carson Valley, west-central Nevada. Arrows indicate direction from right bank to left bank along the well transect. 
Although nitrogen and oxygen isotope samples were collected, in part, to provide additional information on sources of nitrate in groundwater, results of this evaluation were inconclusive. Groundwater-quality data indicate that denitrification is occurring as groundwater moves towards EFCR because the concentrations of nitrate decrease from right to left bank along the well transect, and this process obscures isotopic signatures that may indicate the original source of nitrogen. Reduced nitrate concentrations in groundwater by denitrification were supported by the evaluation of nitrogen and oxygen isotopes and dissolved gases.

\section{Nutrient Loads and Algal Growth}

The nutrient load in a stream or in groundwater is the mass of the constituent of concern transported in a given amount of time. Nitrate and orthophosphate loads in the EFCR and an adjacent area of groundwater discharging to the stream were estimated using water-quality and discharge data for 2012 (table 19).

\section{Stream Nutrient Loads}

Stream-water quality was evaluated to determine how nutrient loads changed downstream between SUT and SDT and over time in summer 2012 (table 19). Stream nitrate loads ranged from a high of 10.5 pounds per day $(\mathrm{lb} / \mathrm{d})$ of $\mathrm{N}$ in early August 2012 at SUT to a low of $0.1 \mathrm{lb} / \mathrm{d}$ of $\mathrm{N}$ in late September 2012 at SUT. Nitrate loads exhibited a decreasing trend with time at a given stream site, and in August 2012, a decreasing trend downstream. In September 2012, the nitrate load was highest at SMT. A loss in stream nitrate load from SUT to SDT in early and late August 2012, combined with contributions of nitrate in groundwater along this reach, indicate that nitrate was being removed from the water column. Processes that could remove nitrate from this reach of the EFCR include algae, uptake by plants and microbes, sorption to sediments, deposition of particulate organic $\mathrm{N}$, and denitrification by bacteria in anaerobic sediment (Hill, 1981; Mulholland and others, 2004). Stream orthophosphate loads ranged from 0.07 to $0.21 \mathrm{lb} / \mathrm{d}$ of $\mathrm{P}$ and exhibited an increasing trend with time at each stream site but no clear trend with location along the study reach. In August 2012, stream orthophosphate loads were highest at SMT, but in September, they were highest at SDT.

\section{Groundwater Nutrient Loads}

For this report, groundwater nutrient loads were only estimated using groundwater discharge by flow-net analysis for the right bank of the study reach between well transect
4 (upper) and well transect 5 (lower). Flow-net analysis estimated a lower groundwater discharge than estimated by seepage runs or chloride mass balance methods. However, the stream reach used for flow-net analysis corresponds to a much shorter but definitively gaining stream reach with higher average algal biomass and much higher groundwater nitrate concentrations.

The estimated groundwater discharge by flow-netanalysis was $0.007 \mathrm{ft}^{3} / \mathrm{s}$ for the right bank between well transect 4 (upper) and well transect 5 (lower), or about $0.09 \mathrm{ft}^{3} / \mathrm{s} / \mathrm{mi}$. This reach is $213 \mathrm{ft}$ upstream of well transect 2 (middle-stream) and $192 \mathrm{ft}$ below well transect 2 (middlestream). For the three sampling events, groundwater nitrate loads ranged from 0.066 to $0.073 \mathrm{lb} / \mathrm{d}$ of $\mathrm{N}$ based on changing groundwater nitrate concentrations (table 19). Estimated groundwater orthophosphate loads were developed using the same estimate of groundwater discharge to the EFCR as for nitrate loads $\left(0.007 \mathrm{ft}^{3} / \mathrm{s}\right)$. Similar to groundwater nitrate loads, orthophosphate loads in groundwater showed minimal variance over time, and based on changing groundwater orthophosphate concentrations, ranged from 0.004 to $0.005 \mathrm{lb} / \mathrm{d}$ of P during summer 2012.

Groundwater contribution of nutrients to the stream provides insight into the role of groundwater discharge to the stream's nutrient balance. Although the groundwater nitrate load remained constant from August to September 2012, the relevance of groundwater nutrient contributions to the stream's nutrient balance increased as the stream nitrate load decreased over time (table 19). A comparison of nitrate loads in the stream at SMT and groundwater loads in the vicinity of SMT reveals that the groundwater nitrate load was only 1 percent of the stream load during early August 2012. In late August and late September 2012, groundwater loads were 4 and 6 percent of stream loads at SMT, respectively. In contrast, the relevance of the groundwater orthophosphate loads to stream loads in the EFCR decreased slightly as stream loads increased over time and were estimated to be about 2-3 percent of stream loads at SMT.

\section{Algal Growth}

Nutrient delivery to algae in the EFCR study reach during the 2012 low streamflow conditions occurred from two sources: from stream inflow to the EFCR study reach and from groundwater discharge to the EFCR between SUT and SDT. In the area of groundwater discharge near SMT, groundwater nitrate and orthophosphate loads were low compared to stream loads (table 19). However, at this same location, nitrate and orthophosphate concentrations in groundwater discharging to the stream were high when compared to the stream concentrations. The high concentrations of nutrients in groundwater discharging to EFCR contribute more to algal growth in the stream than the load of the nutrients entering the stream from groundwater. 
Table 19. Nutrient loads in groundwater and the stream in study reach, 2012, East Fork Carson River, Carson Valley, west-central Nevada.

[Site locations are shown in figures 5 and 6. Abbreviations: Aug., August; lb/d, pound per day; mg/L, milligram per liter; N, nitrogen; P, phosphorus; SDT, East Fork Carson River near Muller Lane downstream transect; Sept., September; SMT, East Fork Carson River near Muller Lane middle-stream transect; SUT, East Fork Carson River near Muller Lane upstream transect; -, not applicable]

\begin{tabular}{|c|c|c|c|c|c|c|c|c|c|c|c|c|c|c|c|c|c|c|}
\hline \multirow{3}{*}{ Location } & \multirow{2}{*}{\multicolumn{3}{|c|}{$\begin{array}{l}\text { Dissolved nitrate plus } \\
\text { nitrite concentration } \\
\text { (mg/L as } \mathrm{N})\end{array}$}} & \multirow{2}{*}{\multicolumn{3}{|c|}{$\begin{array}{c}\text { Dissolved } \\
\text { orthophosphate } \\
\text { (mg/L as P) }\end{array}$}} & \multicolumn{6}{|c|}{ Dissolved nitrate plus nitrite load } & \multicolumn{6}{|c|}{ Dissolved orthophosphate load } \\
\hline & & & & & & & \multicolumn{3}{|c|}{$\begin{array}{l}\text { Stream }{ }^{1} \\
(\mathrm{lb} / \mathrm{d})\end{array}$} & \multicolumn{3}{|c|}{$\begin{array}{l}\text { Groundwater }{ }^{2} \\
\text { (Ib/d) }\end{array}$} & \multicolumn{3}{|c|}{$\begin{array}{l}\text { Stream }^{1} \\
(\mathrm{Ib} / \mathrm{d})\end{array}$} & \multicolumn{3}{|c|}{$\begin{array}{l}\text { Groundwater } \\
\text { (Ib/d) }\end{array}$} \\
\hline & $\begin{array}{l}{ }^{3} \text { Early } \\
\text { Aug. } \\
2012 \\
\end{array}$ & $\begin{array}{l}\text { Late } \\
\text { Aug. } \\
2012\end{array}$ & $\begin{array}{l}\text { Late } \\
\text { Sept. } \\
2012 \\
\end{array}$ & $\begin{array}{l}{ }^{3} \text { Early } \\
\text { Aug. } \\
2012 \\
\end{array}$ & $\begin{array}{l}\text { Late } \\
\text { Aug. } \\
2012\end{array}$ & $\begin{array}{l}\text { Late } \\
\text { Sept. } \\
2012\end{array}$ & $\begin{array}{l}{ }^{3} \text { Early } \\
\text { Aug. } \\
2012 \\
\end{array}$ & $\begin{array}{l}\text { Late } \\
\text { Aug. } \\
2012 \\
\end{array}$ & $\begin{array}{l}\text { Late } \\
\text { Sept. } \\
2012 \\
\end{array}$ & $\begin{array}{l}{ }^{3} \text { Early } \\
\text { Aug. } \\
2012 \\
\end{array}$ & $\begin{array}{l}\text { Late } \\
\text { Aug. } \\
2012 \\
\end{array}$ & $\begin{array}{l}\text { Late } \\
\text { Sept. } \\
2012\end{array}$ & $\begin{array}{l}{ }^{3} \text { Early } \\
\text { Aug. } \\
2012\end{array}$ & $\begin{array}{l}\text { Late } \\
\text { Aug. } \\
2012\end{array}$ & $\begin{array}{l}\text { Late } \\
\text { Sept. } \\
2012 \\
\end{array}$ & $\begin{array}{l}{ }^{3} \text { Early } \\
\text { Aug. } \\
2012 \\
\end{array}$ & $\begin{array}{l}\text { Late } \\
\text { Aug. } \\
2012\end{array}$ & $\begin{array}{l}\text { Late } \\
\text { Sept. } \\
2012 \\
\end{array}$ \\
\hline SUT & 0.86 & 0.21 & $<0.01$ & 0.009 & 0.012 & 0.017 & 10.5 & 2.5 & 0.1 & - & - & - & 0.11 & 0.15 & 0.15 & - & - & - \\
\hline SMT & 0.40 & 0.10 & 0.09 & 0.006 & 0.010 & 0.014 & 7.9 & 1.7 & 1.3 & - & - & - & 0.12 & 0.17 & 0.20 & - & - & - \\
\hline SDT & 0.17 & 0.02 & 0.04 & 0.005 & 0.008 & 0.013 & 2.3 & 0.3 & 0.6 & - & - & - & 0.07 & 0.12 & 0.21 & - & - & - \\
\hline $\begin{array}{l}\text { Right bank observation } \\
\text { wells near } \mathrm{SMT}^{4}\end{array}$ & 1.85 & 1.75 & 1.93 & 0.100 & 0.130 & 0.130 & - & - & - & 0.070 & 0.066 & 0.073 & - & - & - & 0.004 & 0.005 & 0.005 \\
\hline
\end{tabular}

${ }^{1}$ Load calculation uses median streamflow.

${ }^{2}$ Calculation uses average concentration from right bank wells.

${ }^{3}$ Stream dissolved nitrate plus nitrite and dissolved orthophosphate concentration and load at SUT, SMT, and SDT were measured in late July 2012. Groundwater dissolved nitrate plus nitrite and dissolved orthophosphate concentration and load measured in early August 2012.

${ }^{4}$ Right bank observation wells located at well transect 4 (upper), well transect 2 (middle-stream), and well transect 5 (lower). 
Stream conditions in the study reach from July through September 2012 were sufficient to support abundant algae growth (fig. 19; table 17), and the algal biomass was high enough to classify the study reach as eutrophic (table 18). At SUT and SMT, algal biomass based on chl- $a$ concentrations were above the nuisance threshold during July, August, and September. At SDT, algal biomass was well above the nuisance standard in July but well below the threshold during August and September. The pattern of growth at SUT and SMT was similar: chl- $a$ concentrations decreased between July and August but then increased in September. At SDT, the chl- $a$ concentrations were highest in July, decreased substantially by August, and decreased further in September. The average biomass was slightly higher at SMT than at SUT and was lowest at SDT (table 17).

There was no overall positive correlation between stream nutrient concentrations and algal biomass chl- $a$ concentrations ( $r=0.06$ for nitrate, $r=-0.03$ for orthophosphate) in the EFCR during low streamflow conditions in summer 2012. In July, the algal biomass increased downstream, from SUT to SDT, as nitrate and orthophosphate concentrations decreased downstream, and the stream was P limited. In August, algal biomass generally decreased downstream, nitrate and orthophosphate concentrations also decreased downstream, and the stream was limited by either N or P. In September, algal biomass decreased downstream, nitrate concentrations increased slightly and orthophosphate concentrations decreased slightly downstream, and the stream shifted to $\mathrm{N}$ limitation.

One explanation for the lack of a positive correlation between stream nitrate and orthophosphate concentrations and algal biomass during 2012 low streamflow conditions in the study reach is that nutrients were being removed from the stream by periphyton. The amount of nitrate and orthophosphate measured in the stream likely represent the remaining nutrients after algal uptake (Carpenter and others, 2012). Summer 2012 nutrient and algal conditions in EFCR indicate that stream concentrations of biologically available nutrients such as nitrate and orthophosphate will underrepresent true enrichment from nutrients when algal abundance is high (Carpenter and others, 2012).

Another explanation for the lack of a positive correlation between stream nitrate and orthophosphate concentrations and algal biomass in the study reach is that other factors besides stream nutrient concentrations, such as groundwater discharge to the stream, were controlling algal growth. For example, groundwater nitrate concentrations near SMT where nutrientrich groundwater was discharging to the stream correlate well with algal biomass observation at SMT $(r=0.88)$. Although this is only based on three samples, higher groundwater nitrate concentrations were associated with higher chl- $a$ levels. However, groundwater orthophosphate concentrations near SMT were negatively but weakly correlated with algal biomass at SMT ( $r=-0.52)$, also only based on three samples. Although nutrients added to the stream from groundwater discharge should increase the stream nitrate and orthophosphate concentrations, stream concentrations decreased from SUT to SDT in July and August 2012, indicating that nutrients were removed from the stream water by algae. In late September 2012, nitrate concentrations increased from SUT to SMT and then decreased at SDT, although orthophosphate concentration decreased from SUT to SDT.

Nutrient and algal conditions in the study reach during summer 2012 low streamflow conditions highlight an important process occurring at the sediment-water interface within the EFCR. During low streamflow conditions, the addition of nutrients to the stream from the constant supply in groundwater discharge can sustain the growth of algae. Later in the summer and early fall when streamflow is low or extremely low, nutrient-rich groundwater discharge enters the stream through the sediment-water interface at the streambed. Because the attached algae is thick and stream velocity is low, the nutrient-rich water pools at the sediment-water interface. This condition creates a concentration gradient in the stream water column where nutrient concentrations at the streambed are higher than the rest of the stream water column. Higher nutrient concentrations in the benthic zone of a streambed creates a favorable microenvironment for algae attached to the substrate to consume available nutrients from the groundwater before the groundwater mixes with overlying stream water. This hypothesis suggests that excessive algal growth at SMT, for example, could persist because of higher groundwater nutrient concentrations entering the streambed during low streamflow conditions even though groundwater nutrient loads are relatively low when compared to stream nutrient loads. Photographs taken of stream substrate during low streamflow conditions in 2012 confirm the presence of higher periphytic algal biomass along the right bank of the stream, where nutrient-rich groundwater was found to be discharging to the stream in the vicinity of SMT, than the left bank of the stream.

Results of this study also show that conditions existed in the study reach where algal biomass was high and nutrient sources were probably also from upstream of the study reach. At SUT, algal biomass was below the nuisance thresholds during 2010 and was identified as losing streamflow to the adjacent groundwater aquifer. During 2012, algal biomass at SUT was above nuisance thresholds, but no determination was made whether the stream was gaining or losing at SUT. However, seepage runs showed net streamflow gains between SUT and SMT, indicating groundwater was discharging between SUT and SMT. Hence, the high algal biomass at SUT could have been from groundwater inputs. However, higher stream nutrient concentrations at SUT in August 2012 (table 19) likely were the result of upstream urban runoff from the towns of Minden and Gardnerville and irrigation return flow from agricultural land in the surrounding area that enter the EFCR from the Cottonwood Slough tributary (Alvarez and Seiler, 2004). In the summers of 2001 and 2002, three samples were collected from Cottonwood Slough at the mouth of the EFCR and had orthophosphate concentrations ranging from 0.07 to $0.1 \mathrm{mg} / \mathrm{L}$ as $P$ and total nitrate plus nitrite 
concentrations of $0.1 \mathrm{mg} / \mathrm{L}$ as N (Alvarez and Seiler, 2004). If similar nutrient concentrations existed in this tributary during 2012, Cottonwood Slough may have been an upstream source of nutrient concentrations available for uptake by algae and influenced the higher algal biomass conditions observed at SUT.

\section{Summary and Conclusions}

Excessive algal growth and low dissolved oxygen concentrations have been observed during low streamflow summer months along a 5,800-foot reach of the East Fork Carson River in Carson Valley, west-central Nevada. Nutrient enrichment of a stream may lead to excessive algal growth. A study was conducted to evaluate if groundwater discharge to the East Fork Carson River may be a source of nutrients to the 5,800-foot reach of the East Fork Carson River. The study was conducted over the summers of 2010 and 2012 during low streamflow conditions, and this study assessed algal conditions and effects of algae on stream-water quality, potential sources of nitrate in groundwater discharging to the stream, and reduction of nitrate in groundwater by denitrification, in addition to assessing groundwater nutrient contributions to the stream.

The study focused on a 5,800-foot reach of the East Fork Carson River where the greatest algal growth was documented in the past by the Nevada Division of Environmental Protection. Elevated algal biomass was observed in the stream during the summers of 2010 and 2012 based on chlorophyll $a$ concentrations. Only one algae sample collected in 2010, at the middle of the 5,800-foot reach, exceeded the impairment threshold of 150 milligram per square meter $\left(\mathrm{mg} / \mathrm{m}^{2}\right)$ for chlorophyll $a$ concentrations, whereas most of the samples collected in 2012 exceeded the impairment threshold. The study reach was characterized as mesotrophic-eutrophic during 2010 and eutrophic during 2012. An autotrophic index value greater than the threshold value of 400 was exceeded for some samples in 2010 and 2012 at several of the sampling locations, indicating large amounts of degradable organic matter may be entering the surface water. Stream nitrogen to phosphorus ratios from 2010 indicate nitrogen limitation in the stream. In 2012, the ratios were more variable, indicating the stream in the study reach fluctuates between phosphorus and nitrogen limitation.

Stream temperature exceeded the State of Nevada standard on 100 percent of the days monitored in August 2010, 46 percent of days monitored in September 2010, and all the days monitored during July and August of 2012. Average daily minimum and maximum stream temperatures were higher in 2012 compared to 2010. The lower streamflows in 2012 likely contributed to the higher temperatures and more frequent standard exceedances. Daily metabolic cycles of the periphyton in the study area produced dissolved oxygen and $\mathrm{pH}$ concentrations that at times did not meet State of Nevada water-quality standards. The State of Nevada stream dissolved oxygen standard was not met more than 77 percent of days monitored in August 2010 and 50 percent of the days monitored in September 2010. The standard was exceeded 100 percent of the days monitored in 2012. The average minimum daily dissolved oxygen concentration was 1.9 and $2.0 \mathrm{mg} / \mathrm{L}$ in July and September 2012, respectively, well below the standard of $5.0 \mathrm{mg} / \mathrm{L}$. The lower streamflows, higher stream temperatures, and higher algal biomass in 2012 likely contributed to the lower dissolved oxygen concentrations and more frequent exceedance of State standards. Dissolved oxygen saturation values were less than the 50-percent saturation threshold for 9 to 13 percent of the days monitored in 2010 and all days monitored in 2012, indicating levels that are harmful to many aquatic organisms. The presence of algae also caused daily $\mathrm{pH}$ fluctuations with high $\mathrm{pH}$ values in the stream resulting in the State of Nevada stream $\mathrm{pH}$ standard to be occasionally exceeded; however, the exceedances were not as frequent as for other parameters.

An additional component of the study was to evaluate the feasibility of quantifying stream health using assessments of the algal biomass and stream dissolved oxygen as described by Pahl (2007a). The continuous water-quality data show the wide swings in stream dissolved oxygen concentrations that can affect the fish in the stream and indicate the amount of productivity in the stream. The chlorophyll $a$ concentrations determined were useful, but sample collection was difficult. Overall, the methods deployed were useful for determining stream health. Although stream nitrate and total phosphorus concentrations were less than the State water-quality standards during the study, algal biomass levels tended to exceed threshold amounts for nuisance conditions, illustrating how use of nutrient concentrations alone are poor predictors of excessive algal conditions. The amounts of nitrate and orthophosphate measured in the stream likely represent the remaining nutrients after algal uptake.

The study during the summer of 2010 located a subreach of the study reach with nutrient-rich groundwater discharging to the stream. Groundwater discharged to the stream from the right and left banks at the subreach. Nitrate plus nitrite (hereafter referred to as nitrate) were high at the right bank of the subreach (average 2.75 milligrams per liter, $\mathrm{mg} / \mathrm{L}$, as nitrogen). The stream at this location had the highest nitrate concentrations (average $0.056 \mathrm{mg} / \mathrm{L}$ as nitrogen) compared to upstream and downstream locations in the study reach. As a result, a more detailed and focused investigative study occurred in the summer of 2012 along the 405 -foot subreach of the 2010 study reach.

Normalized estimates of groundwater discharge to the right bank of a 405-foot section of the study subreach in 2012 based on a flow-net analysis was 0.09 cubic feet per second per mile. Normalized groundwater discharge to the stream based on stream seepage runs and chloride mass balance in 2012 ranged between not detected to 1.2 cubic feet per second per mile. Specific conductance increased along the study reach in 2012 and likely was caused by discharge of higher specific conductance groundwater between sampling sites. 
Nitrate was the dominant nitrogen species in groundwater and ranged from less than 0.008 to $3.29 \mathrm{mg} / \mathrm{L}$ as nitrogen during the summers of 2010 and 2012. For 2012, generally little temporal and spatial variation was observed in nitrate concentrations in groundwater samples. However, five observation wells had nitrate concentrations greater than $2.0 \mathrm{mg} / \mathrm{L}$ as nitrogen. Groundwater nitrate concentrations generally decreased towards the stream. During 2012, dissolved oxygen concentration decreased toward the stream and ranged from 0.2 to $1.2 \mathrm{mg} / \mathrm{L}$, indicating conditions may have been present for denitrification. Total phosphorus and orthophosphate concentrations were high in some wells in 2010 and 2012.

Groundwater nutrient concentrations were much higher than stream nutrient concentrations in 2012 at the 405-foot subreach of the East Fork Carson River. Average groundwater nitrate and orthophosphate concentrations along the right bank of the 405-foot reach were 9 and 12 times higher, respectively, than in the stream at this subreach. Estimated groundwater discharge rates to the right bank of the study subreach were used to calculate nutrient load estimates to the study subreach, which were found to be low when compared to stream nutrient loads.

The constant supply of nitrate and orthophosphate in groundwater discharging to the stream sustains the growth of algae during summer low streamflow conditions. In the summer when the streamflow is low and after the stream nutrient concentrations have decreased, nutrient-rich groundwater enters the stream through the sediment-water interface. The periphyton is located at the sediment-water interface because it attaches to streambed substrate. Thick periphyton and low stream velocity create a favorable microenvironment for periphyton that assimilate the available nutrients before the groundwater mixes with overlying stream water.

Nitrogen and oxygen isotope concentrations of nitrate in groundwater indicate denitrification is occurring. Further investigation is needed to determine the specific source of the nitrate in the groundwater because the denitrification present in all samples obscures the original source of nitrogen. Although the specific source of nitrate in groundwater was inconclusive, detected organic wastewater compounds in groundwater and nitrate concentrations above background concentrations along the right bank of the subreach indicate anthropogenic influence to the shallow groundwater.

Although this study demonstrated that groundwater is an important component to late summer streamflows and contributes nutrients that can be utilized by algae in the stream, a definitive anthropogenic source of the nitrate in the groundwater was not determined. Monitoring nitrate concentrations in shallow groundwater in the urban area may indicate the extent of the high nitrate concentrations and may help determine the source. If the groundwater in these locations contains oxygen such that aerobic conditions prevail and nitrate concentrations are sufficiently high, then stable isotopes of nitrate and oxygen in groundwater could be used to determine sources of nitrate. In addition, shallow wells near the stream could be analyzed for optical brighteners used in household products such as detergents, which could indicate human influence on groundwater chemistry (Tavares and others, 2008). Mitigation strategies could be initiated as a pilot project to see if nutrient concentrations in the groundwater could be lowered before entering the stream by inserting an artificial reactive barrier that could sequester nutrients (Schipper and others, 2010). In some places along the study reach, the streambanks were devoid of vegetation during the 2010 and 2012 summers. Restoration of a healthy riparian zone could be considered as a means for reducing nutrient concentrations in groundwater while simultaneously reducing the groundwater discharge component to the stream (Ranalli and Macalady, 2010).

\section{References Cited}

Alvarez, N.L., Pahl, R.A., and Rosen, M.R., 2018a, Continuous water quality data for the East Fork Carson River, Carson Valley, west-central Nevada, 2010 and 2012 , in Supplemental data for groundwater contributions to excessive algal growth in the East Fork Carson River, Carson Valley, west-central Nevada, 2010 and 2012: U.S. Geological Survey data release, https://doi.org/10.5066/F7C53K4Q.

Alvarez, N.L., Pahl, R.A., and Rosen, M.R., 2018b, Stream profile data for the East Fork Carson River, Carson Valley, west-central Nevada, 2012, in Supplemental data for groundwater contributions to excessive algal growth in the East Fork Carson River, Carson Valley, west-central Nevada, 2010 and 2012: U.S. Geological Survey data release, https://doi.org/10.5066/F7C53K4Q.

Alvarez, N.L., and Seiler, R.L., 2004, Sources of phosphorus to the Carson River upstream from Lahontan Reservoir, Nevada and California, Water Years 2001-02: U.S. Geological Survey Scientific Investigations Report 2004-5186, 96 p., https://pubs.er.usgs.gov/publication/sir20045186.

Arar, E.J., and Collins G.B., 1997, Method 445.0, In vitro determination of chlorophyll $a$ and pheophytin $a$ in marine and freshwater algae by fluorescence, Revision 1.2: U.S. Environmental Protection Agency, Office of Research and Development, National Exposure Research Laboratory, 22 p., https://cfpub.epa.gov/si/si_public_record_report. cfm?dirEntryld=309417.

Art, H.W., 1993, Eutrophication, in Art, H.W., ed., A dictionary of ecology and environmental science (1st ed.): New York, New York, Henry Holt and Company, p. 196. 
Barnes, K.K., Kolpin, D.W., Furlong, E.T., Zaugg, S.D., Meyer, M.T., and Barber, L.B., 2008, A national reconnaissance of pharmaceuticals and other organic wastewater contaminants in the United States-I) Groundwater: Science of the Total Environment, v. 402 , no. $2-3$, p. $192-200$, https://doi.org/10.1016/j.scitotenv.2008.04.028.

Berger, D.L., and Medina, R.L., 1999, Spatial ground-water data base in Carson Valley, Douglas County, Nevada, and Alpine County, California, development and documentation: U.S. Geological Survey Water-Resources Investigation Report 99-4188, 1 CD-ROM.

Biggs, B.J.F., and Kilroy, C., 2000, Stream periphyton monitoring manual: Christchurch, New Zealand, National Institute of Water and Atmospheric Research, 245 p., https://www.niwa.co.nz/freshwater/management-tools/ ecological-monitoring/stream-periphyton-monitoringmanual.

Bouwer, H., and Rice, R.C., 1976, A slug test for determining hydraulic conductivity of unconfined aquifers with completely or partially penetrating wells: Water Resources Research, v. 12, no. 3, p. 423-428, https://doi.org/10.1029/WR012i003p00423.

Brenton, R.W., and Arnett, T.L., 1993, Methods of analysis by the U.S. Geological Survey National Water Quality Laboratory-Determination of dissolved organic carbon by UV-promoted persulfate oxidation and infrared spectrometry: U.S. Geological Survey Open-File Report 92-480, 12 p., https://pubs.er.usgs.gov/publication/ofr92480.

Britton, L.J., and Greeson, P.E., eds., 1989, Methods for collection and analysis of aquatic biological and microbiological samples: U.S. Geological Survey Techniques of Water-Resources Investigations, book 5, chapter A4, 383 p., https://pubs.er.usgs.gov/publication/twri05A4.

Busenberg, E., Plummer, L.N., Bartholomay, R.C., and Wayland, J.E., 1998, Chlorofluorocarbons, sulfur hexafluoride, and dissolved permanent gases in ground water from selected sites in and near the Idaho National Engineering and Environmental Laboratory, Idaho, 199497: U.S. Geological Survey Open-File Report 98-274, 72 p., https://pubs.er.usgs.gov/publication/ofr98274.

Busenberg, E., Plummer, L.N., Coplen, T.B., Doughten, M.W., Widman, P.K., Casile, G.C., Wayland, J.E., and Nelms, D.L., 2014, A 19-year record of chemical and isotopic composition of water from springs of the Shenandoah National Park, Virginia, 1995-2014: U.S. Geological Survey Data Series 893, 11 p., https://doi.org/10.3133/ds893.
Busenberg, E., Weeks, E.P., Plummer, L.N., and Bartholomay, R.C, 1993, Age dating ground water by use of chlorofluorocarbons $\left(\mathrm{CCl}_{3} \mathrm{~F}\right.$ and $\left.\mathrm{CCl}_{3} \mathrm{~F}_{2}\right)$, and distribution of chlorofluorocarbons in the unsaturated zone, Snake River Plain Aquifer, Idaho National Engineering Laboratory, Idaho: U.S. Geological Survey Water-Resources Investigations Report 93-4054, 47 p., https://pubs.er.usgs.gov/publication/wri934054.

Butler, J.J. Jr., Garnett, E.J., and Healey, J.M., 2003, Analysis of slug tests in formations of high hydraulic conductivity: Groundwater, v. 41, no. 5, p. 620-630, https://doi.org/10.1111/j.1745-6584.2003.tb02400.x.

Carpenter, K.D., Czuba, C.R., Magiri, C.S., Marineau, M.D., Sobieszcyk, S., Czuba, J.A., and Keith, M.K., 2012, Geomorphic setting, aquatic habitat, and water-quality conditions of the Molalla River, Oregon, 2009-10: U.S. Geological Survey Scientific Investigations Report 2012-5017, 78 p., https://pubs.er.usgs.gov/publication/sir20125017.

Casciotti, K.L., Sigman, D.M., Hastings, M.G., Böhlke, J.K., and Hilkert, A., 2002, Measurement of the oxygen isotopic composition of nitrate in seawater and freshwater using the denitrifier method: Analytical Chemistry, v. 74, no. 19, p. 4905-4912, https://doi.org/10.1021/ac020113w.

Childress, C.J.O., Foreman, W.T., Connor, B.F., and Maloney, T.J., 1999, New reporting procedures based on long-term method detection levels and some considerations for interpretations of water-quality data provided by the U.S. Geological Survey National Water Quality Laboratory: U.S. Geological Survey Open-File Report 99-193, 19 p., https://pubs.er.usgs.gov/publication/ofr99193.

Collins, G.B., and Weber, C.I., 1978, Phycoperiphyton (algae) as indicators of water quality: Transactions of the American Microscopical Society, v. 97, no. 1, p. 36-43, http://dx.doi.org/10.2307/3225682.

Coplen, T.B., Böhlke, J.K., and Casciotti, K.L., 2004, Using dual-bacterial denitrification to improve $\delta^{15} \mathrm{~N}$ determinations of nitrates containing mass-independent ${ }^{17} \mathrm{O}$ : Rapid Communications in Mass Spectrometry, v. 18, no. 3, p. 245-250, https://doi.org/10.1002/rcm.1318.

Coplen, T.B., Qi, H., Révész, K., Casciotti, K., and Hannon, J.E., 2012, Determination of the $\delta^{15} \mathrm{~N}$ and $\delta^{18} \mathrm{O}$ of nitrate in water; RSIL lab code 2900, chap. 17 of Stable isotope-ratio methods, sec. C of Révész, K., and Coplen, T.B., eds., Methods of the Reston Stable Isotope Laboratory [slightly revised from version 1.0 released in 2007; supersedes version 1.0 released in 2007]: U.S. Geological Survey Techniques and Methods, book 10, 35 p., https://pubs.usgs.gov/tm/2006/tm10c17/. 
Cox, S.E., Simonds, F.W., Doremus, L., Huffman, R.L., and Defawe, R.M., 2005, Ground water/surface water interactions and quality of discharging ground water in streams of the lower Nooksack River Basin, Whatcom County, Washington: U.S. Geological Survey Scientific Investigations Report 2005-5255, 56 p., https://pubs.er.usgs.gov/publication/sir20055255.

Crain, A.S., Cherry, M.A., Williamson, T.N., and Bunch, A.R., 2017, Multiple-source tracking-Investigating sources of pathogens, nutrients, and sediment in the Upper Little River Basin, Kentucky, water years 2013-14: U.S. Geological Survey Scientific Investigations Report 2017-5086, 60 p., https://doi.org/10.3133/sir20175086.

Cunningham, W.L., and Schalk, C.W., comps., 2011, Groundwater technical procedures of the U.S. Geological Survey: U.S. Geological Survey Techniques and Methods 1-A1, 151 p., https://pubs.usgs.gov/tm/1a1/.

Dodds, W.K., 2007, Trophic state, eutrophication and nutrient criteria in streams: Trends in Ecology and Evolution, v. 22, no. 12, p. 669-676, https://doi.org/10.1016/j.tree.2007.07.010.

Dodds, W.K., Jones, J.R., and Welch, E.B., 1998, Suggested classification of stream trophic state-Distributions of temperate stream types by chlorophyll, total nitrogen, and phosphorus: Water Research, v. 32, no. 5, p. 1455-1462, https://doi.org/10.1016/S0043-1354(97)00370-9.

Elliott, P.E., Beck, D.A., and Prudic, D.E., 2006, Characterization of surface-water resources in the Great Basin National Park area and their susceptibility to groundwater withdrawals in adjacent valleys, White Pine County, Nevada: U.S. Geological Survey Scientific Investigations Report 2006-5099, 157 p., https://pubs.er.usgs.gov/publication/sir20065099.

Fishman, M.J., ed., 1993, Methods of analysis by the U.S. Geological Survey National Water Quality Laboratory-Determination of inorganic and organic constituents in water and fluvial sediments: U.S. Geological Survey Open-File Report 93-125, 217 p, https://pubs.er.usgs.gov/publication/ofr93125.

Fishman, M.J., and Friedman, L.C., eds., 1989, Methods for determination of inorganic substances in water and fluvial sediments: U.S. Geological Survey Techniques of WaterResources Investigations, book 5, chap. A1, 545 p., https://pubs.er.usgs.gov/publication/twri05A1.

Fritsen, C.H., Latham, Z., Memmott, J., Davis, C., and Rost, A., 2006, Dissolved oxygen dynamics in the Carson River, Nevada-Results from field programs during the summers of 2003 and 2004: Reno, Nev., Desert Research Institute publication, 43 p., https://ndep.nv.gov/uploads/ documents/carson_dri_oxygen_dec2006.pdf.
Graham, A.A., McCaughan, D.J., and McKee, F.S., 1988, Measurement of surface area of stones: Hydrobiologia, v.157, no. 1, p. 85-87.

Haack, S.K., and Luukkonen, C.L., 2013, Relation between organic-wastewater compounds, groundwater geochemistry, and well characteristics for selected wells in Lansing, Michigan: U.S. Geological Survey Scientific Investigations Report 2013-5139, 36 p., https://pubs.er.usgs.gov/publication/sir20135139.

Halford, K.J., and Kuniansky, E.L., 2002, Documentation of spreadsheets for the analysis of aquifer-test and slugtest data, version 1.2: U.S. Geological Survey Open-File Report 02-197, 51 p., https://pubs.usgs.gov/of/2002/ofr02197/.

Hambrook Berkman, J.A., and Canova, M.G., 2007, Algal biomass indicators (ver. 1.0): U.S. Geological Survey Techniques of Water-Resources Investigations, book 9, chap. A7, section 7.4, 86 p., https://water.usgs.gov/owq/ FieldManual/Chapter7/7.4.html.

Harte, P.T., 2013, Geochemical, isotopic, and dissolved gas characteristics of groundwater in a fractured crystalline-rock aquifer, Savage Municipal Well Superfund site, Milford, New Hampshire, 2011: U.S. Geological Survey Open-File Report 2013-1089, 25 p., https://pubs.er.usgs.gov/publication/ofr20131089.

Heaton, T.H.E., and Vogel, J.C., 1981, "Excess air" in groundwater: Journal of Hydrology, v. 50, p. 201-216, https://doi.org/10.1016/0022-1694(81)90070-6.

Hem, J.D., 1985, Study and interpretation of the chemical characteristics of natural water: U.S. Geological Survey Water Supply Paper 2254, 263 p., https://pubs.er.usgs.gov/publication/wsp2254.

Hill, A.R., 1981, Nitrate-nitrogen flux and utilization in a stream ecosystem during low summer flows: Canadian Geographer, v. 25, no. 3, p. 225-239, https://doi.org/10.1111/j.1541-0064.1981.tb01643.x.

Katz, B.G., Hornsby, H.D., Bohlke, J.K., and Mokray, M.F., 1999, Sources and chronology of nitrate contamination in spring waters, Suwannee River Basin, Florida: U.S. Geological Survey Water-Resources Investigations Report 99-4252, 54 p., https://pubs.er.usgs.gov/publication/wri994252.

Kendall, C., 1998, Tracing nitrogen sources and cycling in catchments, chap. 16, in Kendall, C., and McDonnell, J.J., eds., Isotope tracers in catchment hydrology: Amsterdam, Elsevier, p. 519-576, https://doi.org/10.1016/B978-0-444-81546-0.50023-9. 
Kendall, C., and Aravena, R., 2000, Nitrate isotopes in groundwater systems, in Cook, P.G., and Herczeg, A.L., eds., Environmental tracers in subsurface hydrology: Norwell, Mass., Kluwer Academic Publishers, p. 261-297.

Kendall, C., Elliott, E.M., and Wankel, S.D., 2007, Tracing anthropogenic inputs of nitrogen to ecosystems, chap. 12, in Michener, R.H., and Lajtha, K., eds., Stable isotopes in ecology and environmental science ( $2 \mathrm{~d}$ ed.): Hoboken, N.J., Blackwell Publishing, p. 375-449.

Lee, K.E., Barber, L.B., Furlong, E.T., Cahill, J.D., Kolpin, D.W., Meyer, M.T., and Zaugg, S.D., 2004, Presence and distribution of organic wastewater compounds in wastewater, surface, ground, and drinking waters, Minnesota, 2000-02: U.S. Geological Survey Scientific Investigation Report 2004-5138, 48 p., https://pubs.er.usgs.gov/publication/sir20045138.

Lindsey, B.D., Phillips, S.W., Donnelly, C.A., Speiran, G.K., Plummer, N.L., Bohlke, J.K., Focazio, M.J., Burton, W.C., and Busenberg, E., 2003, Residence times and nitrate transport in ground water discharging to streams in the Chesapeake Bay Watershed: U.S. Geological Survey WaterResources Investigations Report 2003-4035, 201 p., https://pubs.er.usgs.gov/publication/wri034035.

Mahler, B.J., Musgrove, M., Herrington, C., and Sample, T.L., 2011, Recent (2008-10) concentrations and isotopic compositions of nitrate and concentrations of wastewater compounds in the Barton Springs zone, south-central Texas, and their potential relation to urban development in the contributing zone: U.S. Geological Survey Scientific Investigations Report 2011-5018, 39 p., https://pubs.er.usgs.gov/publication/sir20115018.

Maine Department of Environmental Protection, 2012, Nutrient criteria for surface waters, Chapter 583, Draft revisions to regulations: Maine Department of Environmental Protection publication, 11 p., https://www.maine.gov/dep/water/nutrient-criteria/ chapter583-6-12-2012.pdf.

Manning, A.H., 2009, Ground-water temperature, noble gas, and carbon isotope data from the Espanola Basin, New Mexico: U.S. Geological Survey Scientific Investigations Report 2008-5200, 69 p., https://pubs.er.usgs.gov/publication/sir20085200.

Maurer, D.K., and Berger, D.L., 2006, Water budgets and potential effects of land- and water-use changes for Carson Valley, Douglas County, Nevada, and Alpine County, California: U.S. Geological Survey Scientific Investigations Report 2006-5305, 64 p., https://pubs.er.usgs.gov/publication/sir20065305.
Maurer, D.K., Berger, D.L., Tumbusch, M.L., and Johnson, M.J., 2006, Rates of evapotranspiration, recharge from precipitation beneath selected areas of native vegetation, and streamflow grain and loss in Carson Valley, Douglas County, Nevada, and Alpine County, California: U.S. Geological Survey Scientific Investigations Report 2005-5288, 70 p., https://pubs.er.usgs.gov/publication/sir20055288.

Maurer, D.K., Paul, A.P., Berger, D.L., and Mayers, C.J., 2009, Analysis of streamflow trends, ground-water and surfacewater interactions, and water quality in the upper Carson River Basin, Nevada and California: U.S. Geological Survey Scientific Investigations Report 2008-5238, 192 p., https://pubs.er.usgs.gov/publication/sir20085238.

Maurer, D.K., Watkins, S.A., and Burrows, R.L., 2004, Updated computations and estimates of streamflows tributary to Carson Valley, Douglas County, Nevada, and Alpine County, California: U.S. Geological Survey Scientific Investigations Report 2004-5179, 35 p., https://pubs.er.usgs.gov/publication/sir20045179.

Moulton, S.R. II, Kennen, J.G., Goldstein, R.M., and Hambrook, J.A., 2002, Revised protocols for sampling algal, invertebrate, and fish communities as part of the National Water-Quality Assessment Program: U.S. Geological Survey Open-File Report 2002-150, 75 p., https://pubs.er.usgs.gov/publication/ofr2002150.

Mulholland, P.J., Valett, H.M., Webster, J.R., Thomas, S.A., Cooper, L.W., Hamilton, S.K., and Peterson, B.J., 2004, Stream denitrification and total nitrate uptake rates measured using a field ${ }^{15} \mathrm{~N}$ tracer addition approach: Limnology and Oceanography, v. 49, no. 3, p. 809-820, https://doi.org/10.4319/1o.2004.49.3.0809.

Naranjo, R.C., Welborn, T.L., and Rosen, M.R., 2013, The distribution and modeling of nitrate transport in the Carson Valley alluvial aquifer, Douglas County, Nevada: U.S. Geological Survey Scientific Investigations Report 2013-5136, 51 p., https://pubs.er.usgs.gov/publication/sir20135136.

Nevada Administrative Code, Water controls, Chapter 445A, in 2013 Nevada Revised Statues, https://law.justia.com/codes/nevada/2013/chapter-445a/.

Nevada Division of Environmental Protection, 2004, Nevada's water quality standards and low/high flow statistics (7Q10): Nevada Division of Environmental Protection Fact Sheet, 2 p., https://ndep.nv.gov/uploads/documents/7q10_ fs_2004_1_.pdf. 
Nevada Division of Environmental Protection, 2009, Nutrient assessment protocols for wadeable streams in Nevada, version 2: Nevada Division of Environmental Protection, Bureau of Water Quality Planning, 25 p., https://ndep.nv.gov/uploads/documents/nutrientprotocols_ streams_1_.pdf.

New Mexico Environmental Department, 2011, Appendix D1: Nutrient assessment protocols for wadeable, perennial streams: New Mexico Environmental Department Publication, $13 \mathrm{p}$.

O'Dell, J.W., ed., 1993, Method 365.1, Revision 2.0Determination of phosphorus by semi-automated colorimetry: U.S. Environmental Protection Agency, 17 p., https://www.epa.gov/sites/production/files/2015-08/ documents/method_365-1_1993.pdf.

Pahl, R., 2002, Carson River special monitoring project - 2001: Nevada Division of Environmental Protection, 14 p., https://ndep.nv.gov/uploads/documents/ special_report02.pdf.

Pahl, R., 2006a, Carson River relative bed stability investigation-A supporting document for the Carson River Report Card; September 2006: Nevada Division of Environmental Protection, 58 p., https://ndep.nv.gov/ uploads/documents/bedstable_oct06.pdf.

Pahl, R., 2006b, Carson River special dissolved oxygen and temperature monitoring project-2005-A supporting document for the Carson River Report Card; March 2006: Nevada Division of Environmental Protection, 32 p., https://ndep.nv.gov/uploads/documents/monitor_2005.pdf.

Pahl, R., 2006c, 2004 Nutrient levels in Carson Valley groundwater based upon discharge monitoring reports-A supporting document for the Carson River Report Card: Nevada Division of Environmental Protection, 31 p., https://ndep.nv.gov/uploads/documents/gwnutrient_oct06. pdf.

Pahl, R., 2007a, A review of nutrient conditions and associated water quality standards for the Carson River-A supporting document for the Carson River Report Card: Nevada Division of Environmental Protection, 41 p., https://ndep. nv.gov/uploads/documents/nutrients_nov_07.pdf.

Pahl, R., 2007b, Summary of stream temperature metrics for the Carson River-A supporting document for the Carson River Report Card: Nevada Division of Environmental Protection, 18 p., https://ndep.nv.gov/uploads/documents/ summary_temperature_metrics_carson_river07.pdf.
Pahl, R., 2008, A review of temperature conditions and associated water quality standards for the Carson River-A supporting document for the Carson River Report Card; March 2008: Nevada Division of Environmental Protection, 39 p., https://ndep.nv.gov/uploads/documents/summary_ temperature_carson08.pdf.

Parker, S.P., 1994, Dictionary of scientific and technical terms: New York City, McGraw-Hill, 2,200 p.

Patton, C.J., and Kryskalla, J.R., 2011, Colorimetric determination of nitrate plus nitrite in water by enzymatic reduction, automated discrete analyzer methods: U.S. Geological Survey Techniques and Methods, book 5, chap. B8, 34 p., https://pubs.er.usgs.gov/publication/tm5B8.

Patton, C.J., and Truitt, E.P., 2000, Methods of analysis by the U.S. Geological Survey National Water Quality Laboratory-Determination of ammonium plus organic nitrogen by a Kjeldahl digestion method and an automated photometric finish that includes digest cleanup by gas diffusion: U.S. Geological Survey Open-File Report 2000 170, 31 p., https://pubs.er.usgs.gov/publication/ofr00170.

Plume, R.W., and Smith, J.L., 2013, Properties of basin-fill deposits, a 1971-2000 water budget, and surface-watergroundwater interactions in the upper Humboldt River basin, northeastern Nevada: U.S. Geological Survey Scientific Investigations Report 2013-5077, 46 p., https://pubs.er.usgs.gov/publication/sir20135077.

Puckett, L.J, Zamora, C., Essaid, H., Wilson, J.T., Johnson, H.M., Brayton, M.J., and Vogel, J.R., 2008, Transport and fate of nitrate at the ground-water/surfacewater interface: Journal of Environmental Quality, v. 37, no. 3, p. 1034-1050, https://doi.org/10.2134/jeq2006.0550.

Ranalli, A.J., and Macalady, D.L., 2010, The importance of the riparian zone and in-stream processes in nitrate attenuation in undisturbed and agricultural watersheds - A review of the scientific literature: Journal of Hydrology, v. 389, no. 3-4, p. 406-415, https://doi.org/10.1016/j.jhydrol.2010.05.045.

Rantz, S.E., and others, 1982, Measurement and computation of streamflow: U.S. Geological Survey Water-Supply Paper 2175, 2 v., 631 p.

Rosen, M.R., 2003, Trends in nitrate and dissolved-solids concentrations in ground water, Carson Valley, Douglas County, Nevada, 1985-2001: U.S. Geological Survey Water-Resources Investigations Report 2003-4152, 6 p., https://pubs.er.usgs.gov/publication/wri034152.

Rosenberry, D.O., and Labaugh, J.W., 2008, Field techniques for estimating water fluxes between surface water and ground water: U.S. Geological Survey Techniques and Methods 4-D2, $135 \mathrm{p}$., https://pubs.er.usgs.gov/publication/tm4D2. 
Rush, F.E., 1968, Index to hydrographic areas in Nevada: Nevada Department of Conservation and Natural Resources, Division of Water Resources, Information Report 6, 38 p.

Sauer, V.B., and Meyer, R.W., 1992, Determination of error in individual discharge measurements: U.S. Geological Survey Open-File Report 92-144, 21 p., https://pubs.er.usgs.gov/publication/ofr92144.

Schipper, L.A., Cameron, S.C., and Warneke, S., 2010, Nitrate removal from three different effluents using largescale denitrification beds: Ecological Engineering, v. 36, no. 11 , p. $1552-1557$, https://doi.org/10.1016/j.ecoleng.2010.02.007.

Sigman, D.M., Casciotti, K.L., Andreani, M., Barford, C., Galanter, M., and Böhlke, J.K., 2001, A bacterial method for the nitrogen isotopic analysis of nitrate in seawater and freshwater: Analytical Chemistry, v. 73, no. 17, p. 41454153, https://doi.org/10.1021/ac010088e.

Stonestrom, D.A., and Constantz, J., eds., 2003, Heat as a tool for studying movement of ground water near streams: U.S. Geological Survey Circular 1260, 96 p., https://pubs.er.usgs.gov/publication/cir1260.

Suplee, M.W., Watson, V., Teply, M. and McKee, H., 2009, How green is too green? Public opinion of what constitutes undesirable algae levels in streams: Journal of the American Water Resources Association, v. 45, no. 1, p. 123-140. http://doi.org/10.1111/j.1752-1688.2008.00265.x.

Tavares, M.E., Spivey, M.I.H., McIver, M.R., and Mallin M.A., 2008, Testing for optical brighteners and fecal bacteria to detect sewage leaks in tidal creeks: Journal of North Carolina Academy of Sciences, v. 124, no. 3, p. 91-97, https://www.jstor.org/stable/24336317.

Turnipseed, D.P., and Sauer, V.B., 2010, Discharge measurements at gaging stations: U.S. Geological Survey Techniques and Methods book 3, chap. A8, 87 p., https://pubs.er.usgs.gov/publication/tm3A8.

U.S. Department of the Interior, 1998, Guidelines for interpretation of the biological effects of selected constituents in biota, water, and sediment-Salinity: National Irrigation Water Quality Program Information Report No. 3, 198 p.

U.S. Environmental Protection Agency, 2000, Nutrient criteria technical guidance manual-Rivers and streams: U.S. Environmental Protection Agency, EPA-822-B-00-002, 253 p., https://www.epa.gov/nutrient-policy-data/criteriadevelopment-guidance-rivers-and-streams.

U.S. Geological Survey, variously dated, National field manual for the collection of water-quality data: U.S. Geological Survey Techniques of Water-Resources Investigations, book 9, chaps. A1-A9, https://pubs.water.usgs.gov/twri9A.
U.S. Geological Survey, 2014, Dissolved gas sampling instructions from Reston Chlorofluorocarbon Laboratory: U.S. Geological Survey, accessed July 25, 2014, at https://water.usgs.gov/lab/.

van Haandel, A., and van der Lubbe, J., 2007, Handbook biological wastewater treatment: Leidschendam, Netherlands, Quist Publishing, $570 \mathrm{p}$.

Wagner, R.J., Boulger, R.W., Jr., Oblinger, C.J., and Smith, B.A., 2006, Guidelines and standard procedures for continuous water-quality monitors-Station operation, record computation, and data reporting: U.S. Geological Survey Techniques and Methods 1-D3, 51 p., https://pubs.er.usgs.gov/publication/tm1D3.

Watershed Sciences, Inc., 2006, Airborne thermal infrared remote sensing - Carson River Basin, NV: Submitted by Watershed Sciences, Inc., to Desert Research Institute, 36 p., https://ndep.nv.gov/uploads/documents/carson thermal_jan2007.pdf.

Weiss, R.F., 1970, The solubility of nitrogen, oxygen and argon in water and seawater: Deep Sea Research and Oceanographic Abstracts, v. 17, no. 4, p. 721-735, https://doi.org/10.1016/0011-7471(70)90037-9.

Welch, E.B., and Jacoby, J.M., 2004, Pollutant effects in freshwater-Applied limnology, Third edition: London and New York, Spon Press Publishing, 520 p.

Wetzel, R.G., 2001, Limnology; Third edition; Lake and river ecosystems: San Diego, Calif., Academic Press, 1,006 p.

Wheeler, J.D., and Eddy-Miller, C.A., 2005, Seepage investigation on selected reaches of Fish Creek, Teton County, Wyoming, 2004: U.S. Geological Survey Scientific Investigations Report 2005-5133, 22 p., https://pubs.usgs.gov/sir/2005/5133/.

Wilde, F.D., Radtke, D.B., Gibs, J., and Iwatsubo, R.T., eds., 2004 with updates through 2009, Processing of water samples (ver. 2.2): U.S. Geological Survey Techniques of Water-Resources Investigations, book 9, chap. A5, accessed April 2004 at https://pubs.water.usgs.gov/twri9A5/.

Winter, T.C., Harvey, J.W., Franke, O.L., and Alley, W.M., 1998, Ground water and surface water-A single resource: U.S. Geological Survey Circular 1139, 79 p., https://pubs.er.usgs.gov/publication/cir1139.

Wise, D.R., Zuroske, M.L., Carpenter, K.D., and Kiesling, R.L., 2009, Assessment of eutrophication in the Lower Yakima River Basin, Washington, 2004-07: U.S. Geological Survey Scientific Investigations Report 2009-5078, 108 p., https://pubs.er.usgs.gov/publication/sir20095078. 
Yager, R.M., Maurer, D.K., and Mayers, C.J., 2012, Assessing potential effects of changes in water use with a numerical groundwater-flow model of Carson Valley, Douglas County, Nevada, and Alpine County, California: U.S. Geological Survey Scientific Investigations Report 2012-5262, 84 p., https://pubs.er.usgs.gov/publication/sir20125262.

Zaugg, S.D., Smith, S.G., Schroeder, M.P., Barber, L.B., and Burkhardt, M.R., 2007, Methods of analysis by U.S. Geological Survey National Water Quality Laboratory-Determination of wastewater compounds by polystyrene-divinylbenzene solid-phase extraction and capillary-column gas chromatography/mass spectrometry (ver. 1.1, October 2007): U.S. Geological Survey WaterResources Investigations Report 2001-4186, 37 p., https://pubs.er.usgs.gov/publication/wri20014186. 
Appendix 1. Field Measurements and Nutrient and Chloride Concentrations in Stream and Groundwater Samples Collected Along the East Fork Carson River, 2010, Carson Valley, West-Central Nevada 
Table 1-1. Field measurements and nutrient and chloride concentrations in stream and groundwater samples collected along the East Fork Carson River, 2010, Carson Valley, west-central Nevada.

[b, value extrapolated at low end; Blank, blank sample; d, sample was diluted; E, estimated; Env, environmental sample; hhmm, hour minute; mg/L, milligram per liter; mm/dd/yyyy, month/day/year; $\mathrm{n}$, below the reporting level but at or above the detection level; N, nitrogen; P, phosphorus; Rep, replicate sample; USGS, U.S. Geological Survey; - , no data; <, less than; ${ }^{\circ} \mathrm{C}$, degree Celsius; $\mu \mathrm{S} / \mathrm{cm}$, microsiemen per centimeter at $\left.25^{\circ} \mathrm{C}\right]$

\begin{tabular}{|c|c|c|c|c|c|c|c|c|c|c|c|}
\hline $\begin{array}{c}\text { USGS site } \\
\text { identification } \\
\text { number }\end{array}$ & $\begin{array}{l}\text { Site } \\
\text { short } \\
\text { name }\end{array}$ & $\begin{array}{c}\text { Date } \\
\text { (mm/dd/yyyy) }\end{array}$ & $\begin{array}{c}\text { Time } \\
\text { (hhmm) }\end{array}$ & $\begin{array}{l}\text { Sample } \\
\text { type }\end{array}$ & $\begin{array}{c}\text { Water } \\
\text { temperature } \\
\left({ }^{\circ} \mathrm{C}\right)\end{array}$ & $\begin{array}{c}\text { Air } \\
\text { temperature } \\
\left({ }^{\circ} \mathrm{C}\right)\end{array}$ & $\begin{array}{c}\text { Specific } \\
\text { conductance } \\
(\mu \mathrm{S} / \mathrm{cm})\end{array}$ & $\begin{array}{c}\text { Dissolved } \\
\text { oxygen } \\
\text { (mg/L) }\end{array}$ & $\begin{array}{c}\text { Dissolved oxygen } \\
\text { percent of } \\
\text { saturation }\end{array}$ & $\mathrm{pH}$ & $\begin{array}{c}\text { Total nitrogen } \\
\text { (mg/L) }\end{array}$ \\
\hline \multicolumn{12}{|c|}{ Stream sites 2010} \\
\hline 385708119465604 & SUT & $07 / 28 / 2010$ & 1400 & Blank & - & - & 0 & - & - & - & $<0.12$ \\
\hline 385708119465604 & SUT & 07/29/2010 & 1322 & Env & 24.2 & - & 184 & 7.9 & 111 & 7.7 & 0.48 \\
\hline 385708119465604 & SUT & 09/07/2010 & 1434 & Env & 18.7 & 28.0 & 223 & 10.5 & 134 & 7.9 & 0.32 \\
\hline 385708119465604 & SUT & $10 / 20 / 2010$ & 1430 & Env & 14.8 & - & 183 & 10.8 & 126 & 8.5 & $<0.17$ \\
\hline 385708119465604 & SUT & $10 / 20 / 2010$ & 1435 & Rep & - & - & - & - & - & - & $<0.15$ \\
\hline 385733119471504 & SMT & $07 / 28 / 2010$ & 1047 & Env & 19.8 & 25.5 & 210 & 9.8 & 127 & 7.9 & 0.39 \\
\hline 385733119471504 & SMT & 07/28/2010 & 1052 & Rep & - & - & - & - & - & - & 0.42 \\
\hline 385733119471504 & SMT & 09/08/2010 & 1130 & Env & 14.8 & - & 249 & 11.0 & - & 8.0 & 0.33 \\
\hline 385733119471504 & SMT & $10 / 19 / 2010$ & 1410 & Env & 14.6 & 21.0 & 197 & 9.6 & - & 8.5 & 0.20 \\
\hline 385755119473704 & SDT & $07 / 27 / 2010$ & 1108 & Env & 20.0 & 25.5 & 250 & 12.5 & 163 & 8.1 & 0.47 \\
\hline 385755119473704 & SDT & 09/07/2010 & 1133 & Env & 17.0 & 22.5 & 283 & 12.2 & 150 & 8.1 & 0.24 \\
\hline 385755119473704 & SDT & 09/07/2010 & 1138 & Rep & - & - & - & - & - & - & 0.24 \\
\hline 385755119473704 & SDT & $10 / 19 / 2010$ & 1030 & Blank & - & - & - & - & - & - & $<0.06$ \\
\hline 385755119473704 & SDT & $10 / 19 / 2010$ & 1110 & Env & 12.3 & 15.5 & 204 & 10.7 & - & 8.4 & $<0.18$ \\
\hline \multicolumn{12}{|c|}{ Groundwater sites 2010} \\
\hline 385708119465601 & ULB7 & $07 / 29 / 2010$ & 1100 & Env & 22.2 & - & E180 & 1.0 & E14 & 6.2 & 0.17 \\
\hline 385708119465601 & ULB7 & 09/07/2010 & 1320 & Blank & - & - & 0 & - & - & - & $<0.12$ \\
\hline 385708119465601 & ULB7 & 09/07/2010 & 1530 & Env & 20.0 & - & E209 & 1.1 & E14 & 7.0 & $<0.13$ \\
\hline 385708119465601 & ULB7 & $10 / 20 / 2010$ & 0935 & Env & 13.1 & - & 209 & 0.9 & - & 6.7 & 0.17 \\
\hline 385708119465601 & ULB7 & $10 / 20 / 2010$ & 0940 & Rep & - & - & - & - & - & - & 0.16 \\
\hline 385708119465602 & UMS8 & 07/29/2010 & 1200 & Env & 22.2 & - & E184 & 0.7 & E10 & 6.4 & $<0.20$ \\
\hline 385708119465602 & UMS8 & 09/07/2010 & 1515 & Env & 20.1 & - & E210 & 1.2 & E15 & 6.6 & 0.21 \\
\hline 385708119465602 & UMS8 & $10 / 20 / 2010$ & 1000 & Env & 12.5 & - & 242 & 0.5 & - & 6.6 & $<0.21$ \\
\hline 385708119465603 & URB9 & 07/29/2010 & 1300 & Env & 22.6 & - & E181 & 1.6 & E21 & 5.4 & 0.15 \\
\hline 385708119465603 & URB9 & 07/29/2010 & 1305 & Rep & - & - & - & - & - & - & 0.14 \\
\hline 385708119465603 & URB9 & 09/07/2010 & 1520 & Env & 20.1 & - & E204 & 3.8 & E50 & 7.7 & 0.24 \\
\hline 385708119465603 & URB9 & $10 / 21 / 2010$ & 1100 & Env & 13.5 & - & 186 & 1.3 & - & 6.8 & 0.17 \\
\hline
\end{tabular}


Table 1-1. Field measurements and nutrient and chloride concentrations in stream and groundwater samples collected along the East Fork Carson River, 2010, Carson Valley, west-central Nevada-Continued.

[b, value extrapolated at low end; Blank, blank sample; d, sample was diluted; E, estimated; Env, environmental sample; hhmm, hour minute; mg/L, milligram per liter; mm/dd/yyyy, month/day/year; n, below the reporting level but at or above the detection level; N, nitrogen; P, phosphorus; Rep, replicate sample; USGS, U.S. Geological Survey; -, no data; <, less than; ${ }^{\circ} \mathrm{C}$, degree Celsius; $\mu \mathrm{S} / \mathrm{cm}$, microsiemen per centimeter at $\left.25^{\circ} \mathrm{C}\right]$

\begin{tabular}{|c|c|c|c|c|c|c|c|c|c|c|c|}
\hline $\begin{array}{c}\text { USGS site } \\
\text { identification } \\
\text { number }\end{array}$ & $\begin{array}{c}\text { Site } \\
\text { short } \\
\text { name }\end{array}$ & $\begin{array}{c}\text { Date } \\
\text { (mm/dd/yyyy) }\end{array}$ & $\begin{array}{c}\text { Time } \\
\text { (hhmm) }\end{array}$ & $\begin{array}{c}\text { Sample } \\
\text { type }\end{array}$ & $\begin{array}{c}\text { Water } \\
\text { temperature } \\
\left({ }^{\circ} \mathrm{C}\right)\end{array}$ & $\begin{array}{c}\text { Air } \\
\text { temperature } \\
\left({ }^{\circ} \mathrm{C}\right)\end{array}$ & $\begin{array}{c}\text { Specific } \\
\text { conductance } \\
(\mu S / \mathrm{cm})\end{array}$ & $\begin{array}{c}\text { Dissolved } \\
\text { oxygen } \\
\text { (mg/L) }\end{array}$ & $\begin{array}{c}\text { Dissolved oxygen } \\
\text { percent of } \\
\text { saturation }\end{array}$ & pH & $\begin{array}{l}\text { Total nitrogen } \\
(\mathrm{mg} / \mathrm{L})\end{array}$ \\
\hline \multicolumn{12}{|c|}{ Groundwater sites 2010-Continued } \\
\hline 385733119471501 & MLB4 & $07 / 28 / 2010$ & 1045 & Env & 14.6 & - & E340 & 0.6 & E7 & 6.5 & $<0.20$ \\
\hline 385733119471501 & MLB4 & 09/08/2010 & 1130 & Env & 13.7 & - & 388 & 0.8 & 10 & 6.9 & $<0.18$ \\
\hline 385733119471501 & MLB4 & 09/08/2010 & 1330 & Env & 15.2 & - & 383 & 0.9 & - & 6.9 & $<0.21$ \\
\hline 385733119471501 & MLB4 & 09/08/2010 & 1530 & Env & 14.5 & - & 400 & 0.8 & - & 6.9 & $<0.19$ \\
\hline 385733119471501 & MLB4 & 09/08/2010 & 1730 & Env & 13.9 & - & 400 & 0.7 & - & 6.8 & $<0.18$ \\
\hline 385733119471501 & MLB4 & 09/08/2010 & 1930 & Env & 13.1 & - & 399 & 0.6 & - & 6.9 & $<0.19$ \\
\hline 385733119471501 & MLB4 & 09/08/2010 & 2130 & Env & 12.9 & - & 400 & 0.7 & 8 & 6.9 & $<0.18$ \\
\hline 385733119471501 & MLB4 & 09/08/2010 & 2330 & Env & 12.6 & 7.5 & 399 & 0.6 & 6 & 6.9 & $<0.19$ \\
\hline 385733119471501 & MLB4 & 09/09/2010 & 0130 & Env & 12.2 & 7.5 & 397 & 0.9 & 10 & 6.9 & $<0.16$ \\
\hline 385733119471501 & MLB4 & 09/09/2010 & 0135 & Rep & - & - & - & - & - & - & $<0.20$ \\
\hline 385733119471501 & MLB4 & 09/09/2010 & 0330 & Env & 12.1 & 6.5 & 393 & 0.7 & 8 & 6.9 & $<0.18$ \\
\hline 385733119471501 & MLB4 & 09/09/2010 & 0530 & Env & 11.9 & 5.5 & 396 & 0.7 & 7 & 6.9 & $<0.17$ \\
\hline 385733119471501 & MLB4 & 09/09/2010 & 0730 & Env & 11.9 & 3.0 & 400 & 0.7 & 8 & 6.9 & $<0.17$ \\
\hline 385733119471501 & MLB4 & 09/09/2010 & 1010 & Env & 13.3 & - & 379 & 0.9 & 10 & 6.9 & $<0.22$ \\
\hline 385733119471501 & MLB4 & 09/09/2010 & 1205 & Env & 14.2 & 14.0 & 373 & 0.8 & 9 & 6.9 & $<0.18$ \\
\hline 385733119471501 & MLB4 & 09/09/2010 & 1210 & Rep & - & - & - & - & - & - & $<0.20$ \\
\hline 385733119471501 & MLB4 & $10 / 19 / 2010$ & 1430 & Env & 14.6 & - & 382 & 0.6 & 7 & - & $<0.21$ \\
\hline 385733119471502 & MMS5 & 07/28/2010 & 1200 & Env & 16.9 & - & E345 & 0.8 & E10 & 6.8 & E0.45 \\
\hline 385733119471502 & MMS5 & 09/08/2010 & 1115 & Env & 14.5 & - & 385 & 1.1 & 13 & 7.1 & E0.26 \\
\hline 385733119471502 & MMS5 & 09/08/2010 & 1315 & Env & 15.5 & - & 375 & 1.1 & 13 & 7.0 & E0.25 \\
\hline 385733119471502 & MMS5 & 09/08/2010 & 1515 & Env & 15.5 & - & 379 & 0.7 & - & 7.0 & E0.25 \\
\hline 385733119471502 & MMS5 & 09/08/2010 & 1715 & Env & 15.2 & - & 373 & 1.1 & - & 7.1 & E0.28 \\
\hline 385733119471502 & MMS5 & 09/08/2010 & 1915 & Env & 14.3 & - & 379 & 0.7 & - & 7.1 & E0.27 \\
\hline 385733119471502 & MMS5 & 09/08/2010 & 2115 & Env & 14.1 & - & 380 & 0.7 & 8 & 7.2 & E0.26 \\
\hline 385733119471502 & MMS5 & 09/08/2010 & 2315 & Env & 13.7 & - & 379 & 0.9 & 10 & 7.2 & E0.26 \\
\hline 385733119471502 & MMS5 & 09/08/2010 & 2320 & Rep & - & - & - & - & - & - & E0.26 \\
\hline 385733119471502 & MMS5 & 09/09/2010 & 0115 & Env & 13.6 & 7.5 & 383 & 0.8 & 10 & 7.2 & E0.29 \\
\hline
\end{tabular}


Table 1-1. Field measurements and nutrient and chloride concentrations in stream and groundwater samples collected along the East Fork Carson River, 2010, Carson Valley, west-central Nevada-Continued.

[b, value extrapolated at low end; Blank, blank sample; d, sample was diluted; E, estimated; Env, environmental sample; hhmm, hour minute; mg/L, milligram per liter; mm/dd/yyyy, month/day/year; n, below the reporting level but at or above the detection level; N, nitrogen; P, phosphorus; Rep, replicate sample; USGS, U.S. Geological Survey; - , no data; <, less than; ${ }^{\circ} \mathrm{C}$, degree Celsius; $\mu \mathrm{S} / \mathrm{cm}$, microsiemen per centimeter at $\left.25^{\circ} \mathrm{C}\right]$

\begin{tabular}{|c|c|c|c|c|c|c|c|c|c|c|c|}
\hline $\begin{array}{c}\text { USGS site } \\
\text { identification } \\
\text { number }\end{array}$ & $\begin{array}{l}\text { Site } \\
\text { short } \\
\text { name }\end{array}$ & $\begin{array}{c}\text { Date } \\
\text { (mm/dd/yyyy) }\end{array}$ & $\begin{array}{c}\text { Time } \\
\text { (hhmm) }\end{array}$ & $\begin{array}{l}\text { Sample } \\
\text { type }\end{array}$ & $\begin{array}{c}\text { Water } \\
\text { temperature } \\
\left({ }^{\circ} \mathrm{C}\right)\end{array}$ & $\begin{array}{c}\text { Air } \\
\text { temperature } \\
\left({ }^{\circ} \mathrm{C}\right)\end{array}$ & $\begin{array}{c}\text { Specific } \\
\text { conductance } \\
(\mu \mathrm{S} / \mathrm{cm})\end{array}$ & $\begin{array}{l}\text { Dissolved } \\
\text { oxygen } \\
\text { (mg/L) }\end{array}$ & $\begin{array}{c}\text { Dissolved oxygen } \\
\text { percent of } \\
\text { saturation }\end{array}$ & $\mathrm{pH}$ & $\begin{array}{l}\text { Total nitrogen } \\
(\mathrm{mg} / \mathrm{L})\end{array}$ \\
\hline \multicolumn{12}{|c|}{ Groundwater sites 2010 -Continued } \\
\hline 385733119471502 & MMS5 & 09/09/2010 & 0315 & Env & 13.5 & 6.5 & 380 & 0.7 & 8 & 7.2 & $<0.31$ \\
\hline 385733119471502 & MMS5 & 09/09/2010 & 0515 & Env & 13.3 & 5.5 & 380 & 0.8 & 10 & 7.2 & E0.27 \\
\hline 385733119471502 & MMS5 & 09/09/2010 & 0715 & Env & 12.9 & 1.0 & 380 & 0.8 & 9 & 7.2 & E0.34 \\
\hline 385733119471502 & MMS5 & 09/09/2010 & 0915 & Env & 14.0 & - & 380 & 1.0 & 11 & 7.2 & E0.28 \\
\hline 385733119471502 & MMS5 & 09/09/2010 & 0920 & Rep & - & - & - & - & - & - & E0.29 \\
\hline 385733119471502 & MMS5 & 09/09/2010 & 1135 & Env & 14.5 & 14.0 & 374 & 1.0 & 11 & 7.2 & E0.25 \\
\hline 385733119471502 & MMS5 & $10 / 19 / 2010$ & 1500 & Env & 14.3 & - & 346 & 0.7 & 8 & 6.0 & 0.38 \\
\hline 385733119471503 & MRB6 & 07/28/2010 & 1300 & Env & 16.8 & - & E483 & 0.7 & E9 & 6.4 & 3.2 \\
\hline 385733119471503 & MRB6 & 09/08/2010 & 1100 & Env & 14.1 & 16.5 & 363 & 0.9 & - & 7.2 & 2.7 \\
\hline 385733119471503 & MRB6 & 09/08/2010 & 1300 & Env & 14.6 & 22.0 & 359 & 0.7 & - & 7.2 & 2.7 \\
\hline 385733119471503 & MRB6 & 09/08/2010 & 1500 & Env & 14.7 & 19.0 & 425 & 0.9 & - & 6.7 & E2.7 \\
\hline 385733119471503 & MRB6 & 09/08/2010 & 1700 & Env & 14.7 & - & 434 & 0.6 & - & 6.5 & E2.8 \\
\hline 385733119471503 & MRB6 & 09/08/2010 & 1900 & Env & 13.9 & - & 434 & 0.7 & - & 6.5 & E2.8 \\
\hline 385733119471503 & MRB6 & 09/08/2010 & 2100 & Env & 13.4 & - & 436 & 0.5 & 6 & 6.6 & 2.8 \\
\hline 385733119471503 & MRB6 & 09/08/2010 & 2105 & Rep & - & - & - & - & - & - & 2.8 \\
\hline 385733119471503 & MRB6 & 09/08/2010 & 2300 & Env & 13.2 & - & 439 & 0.5 & 5 & 6.6 & E2.7 \\
\hline 385733119471503 & MRB6 & 09/09/2010 & 0100 & Env & 13.3 & 7.5 & 441 & 0.8 & 9 & 6.6 & 2.8 \\
\hline 385733119471503 & MRB6 & 09/09/2010 & 0300 & Env & 13.2 & 6.5 & 442 & 0.7 & 8 & 6.6 & 2.8 \\
\hline 385733119471503 & MRB6 & 09/09/2010 & 0500 & Env & 13.2 & 5.5 & 440 & 0.8 & 10 & 6.6 & 2.8 \\
\hline 385733119471503 & MRB6 & 09/09/2010 & 0700 & Env & 12.7 & 4.0 & 444 & 0.9 & 10 & 6.6 & 2.8 \\
\hline 385733119471503 & MRB6 & 09/09/2010 & 0705 & Rep & - & - & - & - & - & - & 2.8 \\
\hline 385733119471503 & MRB6 & 09/09/2010 & 0900 & Env & 13.2 & 8.0 & 444 & 0.8 & 9 & 6.5 & E2.7 \\
\hline 385733119471503 & MRB6 & 09/09/2010 & 1100 & Env & 13.9 & 14.0 & 447 & 0.6 & 7 & 6.4 & 2.8 \\
\hline 385733119471503 & MRB6 & $10 / 19 / 2010$ & 1520 & Env & 15.6 & - & 464 & 0.7 & 8 & 6.5 & 2.7 \\
\hline 385755119473701 & DLB1 & 07/27/2010 & 1100 & Env & 20.6 & - & E235 & 1.3 & - & 6.9 & 0.33 \\
\hline 385755119473701 & DLB1 & 09/07/2010 & 1130 & Env & 18.4 & - & E267 & 1.6 & E20 & 8.1 & 0.28 \\
\hline 385755119473701 & DLB1 & $10 / 19 / 2010$ & 1015 & Blank & - & - & 0 & - & - & - & $<0.06$ \\
\hline
\end{tabular}


Table 1-1. Field measurements and nutrient and chloride concentrations in stream and groundwater samples collected along the East Fork Carson River, 2010, Carson Valley, west-central Nevada-Continued.

[b, value extrapolated at low end; Blank, blank sample; d, sample was diluted; E, estimated; Env, environmental sample; hhmm, hour minute; mg/L, milligram per liter; mm/dd/yyyy, month/day/year; n, below the reporting level but at or above the detection level; N, nitrogen; P, phosphorus; Rep, replicate sample; USGS, U.S. Geological Survey; —, no data; <, less than; ${ }^{\circ} \mathrm{C}$, degree Celsius; $\mu \mathrm{S} / \mathrm{cm}$, microsiemen per centimeter at $\left.25^{\circ} \mathrm{C}\right]$

\begin{tabular}{|c|c|c|c|c|c|c|c|c|c|c|c|}
\hline $\begin{array}{c}\text { USGS site } \\
\text { identification } \\
\text { number }\end{array}$ & $\begin{array}{l}\text { Site } \\
\text { short } \\
\text { name }\end{array}$ & $\begin{array}{c}\text { Date } \\
\text { (mm/dd/yyyy) }\end{array}$ & $\begin{array}{c}\text { Time } \\
\text { (hhmm) }\end{array}$ & $\begin{array}{l}\text { Sample } \\
\text { type }\end{array}$ & $\begin{array}{c}\text { Water } \\
\text { temperature } \\
\left({ }^{\circ} \mathrm{C}\right)\end{array}$ & $\begin{array}{c}\text { Air } \\
\text { temperature } \\
\left({ }^{\circ} \mathrm{C}\right)\end{array}$ & $\begin{array}{c}\text { Specific } \\
\text { conductance } \\
(\mu \mathrm{S} / \mathrm{cm})\end{array}$ & $\begin{array}{l}\text { Dissolved } \\
\text { oxygen } \\
\text { (mg/L) }\end{array}$ & $\begin{array}{l}\text { issolved oxygen } \\
\text { percent of } \\
\text { saturation }\end{array}$ & pH & $\begin{array}{l}\text { Total nitrogen } \\
\text { (mg/L) }\end{array}$ \\
\hline \multicolumn{12}{|c|}{ Groundwater sites 2010 -Continued } \\
\hline 385755119473701 & DLB1 & $10 / 19 / 2010$ & 1125 & Env & 13.5 & - & 220 & 2.1 & 24 & 6.6 & 0.34 \\
\hline 385755119473702 & DMS2 & 07/27/2010 & 1215 & Env & 20.6 & - & E250 & 0.9 & - & 4.9 & E0.20 \\
\hline 385755119473702 & DMS2 & 09/07/2010 & 1200 & Env & 20.3 & - & E273 & 0.9 & E12 & 6.5 & E0.17 \\
\hline 385755119473702 & DMS2 & $10 / 19 / 2010$ & 1145 & Env & 14.3 & - & 218 & 1.6 & 18 & 6.6 & 0.21 \\
\hline 385755119473703 & DRB3 & $07 / 27 / 2010$ & 1300 & Env & 20.6 & - & E238 & 0.9 & - & 5.5 & $<0.26$ \\
\hline 385755119473703 & DRB3 & $07 / 27 / 2010$ & 1345 & Blank & - & - & E0.0 & - & - & - & $<0.12$ \\
\hline 385755119473703 & DRB3 & 09/07/2010 & 1215 & Env & 20.4 & - & E272 & 0.8 & E11 & 6.0 & $<0.17$ \\
\hline 385755119473703 & DRB3 & 09/07/2010 & 1220 & Rep & - & - & - & - & - & - & E0.37 \\
\hline 385755119473703 & DRB3 & $10 / 19 / 2010$ & 1205 & Env & 14.9 & - & 224 & 0.8 & 9 & 6.2 & 0.12 \\
\hline 385755119473705 & DLB10 & 09/07/2010 & 1310 & Env & - & - & - & - & - & - & $<0.20$ \\
\hline 385755119473705 & DLB10 & $10 / 19 / 2010$ & 1310 & Env & - & - & - & - & - & - & $<0.22$ \\
\hline $\begin{array}{c}\text { USGS site } \\
\text { identification } \\
\text { number }\end{array}$ & $\begin{array}{l}\text { Site } \\
\text { short } \\
\text { name }\end{array}$ & $\begin{array}{c}\text { Date } \\
\text { (mm/dd/yyyy) }\end{array}$ & $\begin{array}{c}\text { Time } \\
\text { (hhmm) }\end{array}$ & $\begin{array}{l}\text { Sample } \\
\text { type }\end{array}$ & $\begin{array}{c}\text { Total ammonia plus } \\
\text { organic nitrogen } \\
\text { (mg/L as } \mathrm{N} \text { ) }\end{array}$ & $\begin{array}{l}\text { Total organic } \\
\text { nitrogen } \\
\text { (mg/L as } \mathrm{N} \text { ) }\end{array}$ & $\begin{array}{c}\text { Dissolved nitrate } \\
\text { plus nitrite } \\
\text { (mg/L as } \mathrm{N})\end{array}$ & $\begin{array}{l}\text { Dissolved } \\
\text { ammonia } \\
\text { (mg/L as N) }\end{array}$ & $\begin{array}{l}\text { Dissolved } \\
\text { chloride } \\
\text { (mg/L) }\end{array}$ & $\begin{array}{c}\text { Total } \\
\text { phosphorus } \\
\text { (mg/L as } \mathrm{P})\end{array}$ & $\begin{array}{c}\text { Dissolved } \\
\text { orthophosphate } \\
\text { (mg/L as } \mathrm{P})\end{array}$ \\
\hline \multicolumn{12}{|c|}{ Stream sites 2010-Continued } \\
\hline 385708119465604 & SUT & $07 / 28 / 2010$ & 1400 & Blank & $<0.10$ & $<0.10$ & $<0.016$ & $<0.02$ & $<0.12$ & $<0.008$ & $<0.008$ \\
\hline 385708119465604 & SUT & 07/29/2010 & 1322 & Env & 0.43 & E0.41 & 0.053 & E0.02 n & 3.25 & 0.070 & 0.038 \\
\hline 385708119465604 & SUT & 09/07/2010 & 1434 & Env & 0.28 & $<0.28$ & 0.038 & $<0.02$ & 4.33 & 0.040 & 0.021 \\
\hline 385708119465604 & SUT & $10 / 20 / 2010$ & 1430 & Env & 0.16 & $<0.16$ & $<0.008$ & $<0.01$ & 5.85 & 0.022 & 0.015 \\
\hline 385708119465604 & SUT & $10 / 20 / 2010$ & 1435 & Rep & 0.15 & $<0.15$ & $<0.008$ & $<0.01$ & 5.86 & 0.021 & 0.014 \\
\hline 385733119471504 & SMT & $07 / 28 / 2010$ & 1047 & Env & 0.30 & $<0.30$ & 0.089 & $<0.02$ & 3.87 & 0.057 & 0.031 \\
\hline 385733119471504 & SMT & $07 / 28 / 2010$ & 1052 & Rep & 0.34 & $<0.34$ & 0.090 & $<0.02$ & 3.86 & 0.055 & 0.030 \\
\hline 385733119471504 & SMT & 09/08/2010 & 1130 & Env & 0.26 & $<0.26$ & 0.068 & $<0.02$ & 5.08 & 0.052 & 0.018 \\
\hline 385733119471504 & SMT & $10 / 19 / 2010$ & 1410 & Env & 0.19 & $<0.19$ & $0.010 \mathrm{bn}$ & $<0.01$ & 6.17 & 0.028 & 0.016 \\
\hline 385755119473704 & SDT & $07 / 27 / 2010$ & 1108 & Env & 0.39 & $<0.39$ & 0.079 & $<0.02$ & 5.17 & 0.052 & 0.028 \\
\hline 385755119473704 & SDT & 09/07/2010 & 1133 & Env & 0.21 & $<0.21$ & 0.032 & $<0.02$ & 6.19 & 0.029 & 0.020 \\
\hline 385755119473704 & SDT & 09/07/2010 & 1138 & Rep & 0.21 & $<0.21$ & 0.033 & $<0.02$ & 6.22 & 0.029 & 0.019 \\
\hline
\end{tabular}


Table 1-1. Field measurements and nutrient and chloride concentrations in stream and groundwater samples collected along the East Fork Carson River, 2010, Carson Valley, west-central Nevada-Continued.

[b, value extrapolated at low end; Blank, blank sample; d, sample was diluted; E, estimated; Env, environmental sample; hhmm, hour minute; mg/L, milligram per liter; mm/dd/yyyy, month/day/year; n, below the reporting level but at or above the detection level; N, nitrogen; P, phosphorus; Rep, replicate sample; USGS, U.S. Geological Survey; - , no data; <, less than; ${ }^{\circ} \mathrm{C}$, degree Celsius; $\mu \mathrm{S} / \mathrm{cm}$, microsiemen per centimeter at $\left.25^{\circ} \mathrm{C}\right]$

\begin{tabular}{|c|c|c|c|c|c|c|c|c|c|c|c|}
\hline $\begin{array}{c}\text { USGS site } \\
\text { identification } \\
\text { number }\end{array}$ & $\begin{array}{l}\text { Site } \\
\text { short } \\
\text { name }\end{array}$ & $\begin{array}{c}\text { Date } \\
\text { (mm/dd/yyyy) }\end{array}$ & $\begin{array}{c}\text { Time } \\
\text { (hhmm) }\end{array}$ & $\begin{array}{c}\text { Sample } \\
\text { type }\end{array}$ & $\begin{array}{c}\text { Total ammonia plus } \\
\text { organic nitrogen } \\
\text { (mg/L as } \mathrm{N})\end{array}$ & $\begin{array}{c}\text { Total organic } \\
\text { nitrogen } \\
\text { (mg/L as } \mathrm{N})\end{array}$ & $\begin{array}{c}\text { Dissolved nitrate } \\
\text { plus nitrite } \\
\text { (mg/L as } \mathrm{N})\end{array}$ & $\begin{array}{l}\text { Dissolved } \\
\text { ammonia } \\
\text { (mg/L as N) }\end{array}$ & $\begin{array}{l}\text { Dissolved } \\
\text { chloride } \\
\text { (mg/L) }\end{array}$ & $\begin{array}{c}\text { Total } \\
\text { phosphorus } \\
\text { (mg/L as P) }\end{array}$ & $\begin{array}{c}\text { Dissolved } \\
\text { orthophosphate } \\
\text { (mg/L as P) }\end{array}$ \\
\hline \multicolumn{12}{|c|}{ Stream sites 2010 —Continued } \\
\hline 385755119473704 & SDT & $10 / 19 / 2010$ & 1030 & Blank & $0.05 \mathrm{bn}$ & $<0.05$ & $<0.008$ & $<0.01$ & $<0.06$ & $<0.004$ & $<0.004$ \\
\hline 385755119473704 & SDT & $10 / 19 / 2010$ & 1110 & Env & 0.17 & $<0.17$ & $<0.008$ & $<0.01$ & 6.41 & 0.025 & 0.015 \\
\hline \multicolumn{12}{|c|}{ Groundwater sites 2010-Continued } \\
\hline 385708119465601 & ULB7 & 07/29/2010 & 1100 & Env & 0.14 & $<0.14$ & 0.028 & $<0.02$ & 3.30 & 0.025 & 0.028 \\
\hline 385708119465601 & ULB7 & 09/07/2010 & 1320 & Blank & $<0.10$ & $<0.10$ & $<0.016$ & $<0.02$ & $<0.12$ & $<0.008$ & $<0.008$ \\
\hline 385708119465601 & ULB7 & 09/07/2010 & 1530 & Env & 0.11 & $<0.11$ & $<0.016$ & $<0.02$ & 4.30 & 0.029 & 0.032 \\
\hline 385708119465601 & ULB7 & $10 / 20 / 2010$ & 0935 & Env & $0.09 \mathrm{bn}$ & $<0.09$ & 0.082 & $<0.01$ & 6.18 & 0.025 & 0.029 \\
\hline 385708119465601 & ULB7 & $10 / 20 / 2010$ & 0940 & Rep & $0.08 \mathrm{bn}$ & $<0.08$ & 0.082 & $<0.01$ & 6.21 & 0.026 & 0.029 \\
\hline 385708119465602 & UMS8 & 07/29/2010 & 1200 & Env & 0.18 & $<0.18$ & $<0.016$ & $<0.02$ & 3.31 & 0.034 & 0.033 \\
\hline 385708119465602 & UMS8 & 09/07/2010 & 1515 & Env & 0.16 & $<0.16$ & 0.059 & $<0.02$ & 4.31 & 0.038 & 0.040 \\
\hline 385708119465602 & UMS8 & $10 / 20 / 2010$ & 1000 & Env & 0.21 & $<0.21$ & $<0.008$ & $<0.01$ & 6.14 & 0.088 & 0.063 \\
\hline 385708119465603 & URB9 & 07/29/2010 & 1300 & Env & 0.13 & $<0.13$ & 0.022 & $<0.02$ & 3.25 & 0.028 & 0.028 \\
\hline 385708119465603 & URB9 & 07/29/2010 & 1305 & Rep & 0.12 & $<0.12$ & 0.020 & $<0.02$ & 3.26 & 0.027 & 0.028 \\
\hline 385708119465603 & URB9 & 09/07/2010 & 1520 & Env & 0.15 & $<0.15$ & 0.090 & $<0.02$ & 4.27 & 0.023 & 0.030 \\
\hline 385708119465603 & URB9 & $10 / 21 / 2010$ & 1100 & Env & 0.09 bn & $<0.09$ & 0.086 & $<0.01$ & 6.02 & 0.021 & 0.028 \\
\hline 385733119471501 & MLB4 & $07 / 28 / 2010$ & 1045 & Env & 0.19 & 0.11 & $<0.016$ & 0.08 & 5.45 & 0.138 & 0.047 \\
\hline 385733119471501 & MLB4 & 09/08/2010 & 1130 & Env & 0.17 & 0.09 & $<0.016$ & 0.08 & 5.46 & 0.147 & 0.024 \\
\hline 385733119471501 & MLB4 & 09/08/2010 & 1330 & Env & 0.19 & 0.11 & $<0.016$ & 0.08 & 5.49 & 0.146 & 0.023 \\
\hline 385733119471501 & MLB4 & 09/08/2010 & 1530 & Env & 0.17 & 0.09 & $<0.016$ & 0.08 & 5.48 & 0.143 & 0.020 \\
\hline 385733119471501 & MLB4 & 09/08/2010 & 1730 & Env & 0.16 & 0.08 & $<0.016$ & 0.08 & 5.45 & 0.142 & 0.024 \\
\hline 385733119471501 & MLB4 & 09/08/2010 & 1930 & Env & 0.18 & 0.09 & $<0.016$ & 0.08 & 5.48 & 0.142 & 0.021 \\
\hline 385733119471501 & MLB4 & 09/08/2010 & 2130 & Env & 0.17 & 0.08 & $<0.016$ & 0.08 & 5.51 & 0.140 & 0.023 \\
\hline 385733119471501 & MLB4 & 09/08/2010 & 2330 & Env & 0.17 & 0.09 & $<0.016$ & 0.08 & 5.45 & 0.143 & 0.023 \\
\hline 385733119471501 & MLB4 & 09/09/2010 & 0130 & Env & 0.14 & 0.06 & $<0.016$ & 0.08 & 5.51 & 0.141 & 0.021 \\
\hline 385733119471501 & MLB4 & 09/09/2010 & 0135 & Rep & 0.18 & 0.10 & $<0.016$ & 0.08 & 5.51 & 0.142 & 0.021 \\
\hline 385733119471501 & MLB4 & 09/09/2010 & 0330 & Env & 0.17 & 0.09 & $<0.016$ & 0.08 & 5.49 & 0.142 & 0.022 \\
\hline 385733119471501 & MLB4 & 09/09/2010 & 0530 & Env & 0.16 & 0.08 & $<0.016$ & 0.08 & 5.51 & 0.139 & 0.021 \\
\hline 385733119471501 & MLB4 & 09/09/2010 & 0730 & Env & 0.16 & 0.07 & $<0.016$ & 0.08 & 5.47 & 0.141 & 0.021 \\
\hline
\end{tabular}


Table 1-1. Field measurements and nutrient and chloride concentrations in stream and groundwater samples collected along the East Fork Carson River, 2010, Carson Valley, west-central Nevada-Continued.

[b, value extrapolated at low end; Blank, blank sample; d, sample was diluted; E, estimated; Env, environmental sample; hhmm, hour minute; mg/L, milligram per liter; mm/dd/yyyy, month/day/year; n, below the reporting level but at or above the detection level; N, nitrogen; P, phosphorus; Rep, replicate sample; USGS, U.S. Geological Survey; -, no data; <, less than; ${ }^{\circ} \mathrm{C}$, degree Celsius; $\mu \mathrm{S} / \mathrm{cm}$, microsiemen per centimeter at $\left.25^{\circ} \mathrm{C}\right]$

\begin{tabular}{|c|c|c|c|c|c|c|c|c|c|c|c|}
\hline $\begin{array}{c}\text { USGS site } \\
\text { identification } \\
\text { number }\end{array}$ & $\begin{array}{l}\text { Site } \\
\text { short } \\
\text { name }\end{array}$ & $\begin{array}{c}\text { Date } \\
\text { (mm/dd/yyyy) }\end{array}$ & $\begin{array}{c}\text { Time } \\
\text { (hhmm) }\end{array}$ & $\begin{array}{l}\text { Sample } \\
\text { type }\end{array}$ & $\begin{array}{c}\text { Total ammonia plus } \\
\text { organic nitrogen } \\
\text { (mg/L as } \mathrm{N} \text { ) }\end{array}$ & $\begin{array}{c}\text { Total organic } \\
\text { nitrogen } \\
\text { (mg/L as } \mathrm{N} \text { ) }\end{array}$ & $\begin{array}{c}\text { Dissolved nitrate } \\
\text { plus nitrite } \\
\text { (mg/L as } \mathrm{N})\end{array}$ & $\begin{array}{c}\text { Dissolved } \\
\text { ammonia } \\
\text { (mg/L as N) }\end{array}$ & $\begin{array}{l}\text { Dissolved } \\
\text { chloride } \\
\text { (mg/L) }\end{array}$ & $\begin{array}{c}\text { Total } \\
\text { phosphorus } \\
\text { (mg/L as } \mathrm{P})\end{array}$ & $\begin{array}{c}\text { Dissolved } \\
\text { orthophosphate } \\
\text { (mg/L as P) }\end{array}$ \\
\hline \multicolumn{12}{|c|}{ Groundwater sites 2010-Continued } \\
\hline 385733119471501 & MLB4 & 09/09/2010 & 1010 & Env & 0.21 & 0.12 & $<0.016$ & 0.09 & 5.46 & 0.138 & 0.028 \\
\hline 385733119471501 & MLB4 & 09/09/2010 & 1205 & Env & 0.17 & 0.09 & $<0.016$ & 0.08 & 5.52 & 0.139 & 0.019 \\
\hline 385733119471501 & MLB4 & 09/09/2010 & 1210 & Rep & 0.18 & 0.10 & $<0.016$ & 0.08 & 5.53 & 0.139 & 0.021 \\
\hline 385733119471501 & MLB4 & $10 / 19 / 2010$ & 1430 & Env & 0.20 & 0.12 & $<0.008$ & 0.08 & 5.41 & 0.138 & 0.022 \\
\hline 385733119471502 & MMS5 & $07 / 28 / 2010$ & 1200 & Env & E0.07 n & $<0.07$ & 0.380 & $<0.02$ & 7.85 & 0.039 & 0.041 \\
\hline 385733119471502 & MMS5 & 09/08/2010 & 1115 & Env & E0.08 n & $<0.08$ & 0.180 & $<0.02$ & 7.35 & 0.045 & 0.038 \\
\hline 385733119471502 & MMS5 & 09/08/2010 & 1315 & Env & E0.07 n & $<0.07$ & 0.180 & $<0.02$ & 7.30 & 0.043 & 0.037 \\
\hline 385733119471502 & MMS5 & 09/08/2010 & 1515 & Env & E0.06 n & $<0.06$ & 0.186 & $<0.02$ & 7.24 & 0.043 & 0.038 \\
\hline 385733119471502 & MMS5 & 09/08/2010 & 1715 & Env & E0.09 n & $<0.09$ & 0.189 & $<0.02$ & 7.33 & 0.047 & 0.037 \\
\hline 385733119471502 & MMS5 & 09/08/2010 & 1915 & Env & E0.08 n & E0.07 & 0.194 & E0.01 n & 7.34 & 0.043 & 0.039 \\
\hline 385733119471502 & MMS5 & 09/08/2010 & 2115 & Env & E0.05 n & E0.04 & 0.206 & E0.01 n & 7.33 & 0.042 & 0.037 \\
\hline 385733119471502 & MMS5 & 09/08/2010 & 2315 & Env & E0.06 n & E0.05 & 0.205 & $\mathrm{E} 0.01 \mathrm{n}$ & 7.37 & 0.041 & 0.037 \\
\hline 385733119471502 & MMS5 & 09/08/2010 & 2320 & Rep & E0.05 n & E0.04 & 0.203 & $\mathrm{E} 0.01 \mathrm{n}$ & 7.35 & 0.042 & 0.035 \\
\hline 385733119471502 & MMS5 & 09/09/2010 & 0115 & Env & E0.09 n & E0.07 & 0.204 & $\mathrm{E} 0.01 \mathrm{n}$ & 7.29 & 0.040 & 0.032 \\
\hline 385733119471502 & MMS5 & 09/09/2010 & 0315 & Env & $<0.10$ & $<0.09$ & 0.213 & E0.01 n & 7.38 & 0.043 & 0.038 \\
\hline 385733119471502 & MMS5 & 09/09/2010 & 0515 & Env & E0.06 n & E0.05 & 0.209 & $\mathrm{E} 0.01 \mathrm{n}$ & 7.38 & 0.041 & 0.038 \\
\hline 385733119471502 & MMS5 & 09/09/2010 & 0715 & Env & E0.05 n & - & 0.292 & 0.39 & 7.42 & 0.042 & 0.030 \\
\hline 385733119471502 & MMS5 & 09/09/2010 & 0915 & Env & E0.07 n & E0.06 & 0.208 & $\mathrm{E} 0.01 \mathrm{n}$ & 7.40 & 0.042 & 0.038 \\
\hline 385733119471502 & MMS5 & 09/09/2010 & 0920 & Rep & E0.08 n & $<0.08$ & 0.203 & $<0.02$ & 7.42 & 0.042 & 0.037 \\
\hline 385733119471502 & MMS5 & 09/09/2010 & 1135 & Env & E0.06 n & $<0.06$ & 0.192 & $<0.02$ & 7.35 & 0.042 & 0.036 \\
\hline 385733119471502 & MMS5 & $10 / 19 / 2010$ & 1500 & Env & $0.09 \mathrm{bn}$ & $<0.09$ & 0.292 & $<0.01$ & 7.05 & 0.035 & 0.039 \\
\hline 385733119471503 & MRB6 & 07/28/2010 & 1300 & Env & 0.15 & E0.14 & $3.00 \mathrm{~d}$ & $\mathrm{E} 0.01 \mathrm{n}$ & 13.7 & 0.055 & 0.067 \\
\hline 385733119471503 & MRB6 & 09/08/2010 & 1100 & Env & 0.11 & E0.09 & $2.62 \mathrm{~d}$ & E0.02 n & 9.18 & 0.060 & 0.071 \\
\hline 385733119471503 & MRB6 & 09/08/2010 & 1300 & Env & 0.10 & E0.09 & $2.63 \mathrm{~d}$ & $\mathrm{E} 0.01 \mathrm{n}$ & 9.42 & 0.058 & 0.072 \\
\hline 385733119471503 & MRB6 & 09/08/2010 & 1500 & Env & E0.07 n & E0.05 & $2.63 \mathrm{~d}$ & E0.01 n & 9.66 & 0.058 & 0.070 \\
\hline 385733119471503 & MRB6 & 09/08/2010 & 1700 & Env & E0.07 n & E0.06 & $2.68 \mathrm{~d}$ & E0.01 n & 9.79 & 0.058 & 0.070 \\
\hline 385733119471503 & MRB6 & 09/08/2010 & 1900 & Env & E0.07 n & E0.06 & $2.68 \mathrm{~d}$ & $\mathrm{E} 0.01 \mathrm{n}$ & 10.0 & 0.058 & 0.070 \\
\hline
\end{tabular}


Table 1-1. Field measurements and nutrient and chloride concentrations in stream and groundwater samples collected along the East Fork Carson River, 2010, Carson Valley, west-central Nevada-Continued.

[b, value extrapolated at low end; Blank, blank sample; d, sample was diluted; E, estimated; Env, environmental sample; hhmm, hour minute; mg/L, milligram per liter; mm/dd/yyyy, month/day/year; n, below the reporting level but at or above the detection level; N, nitrogen; P, phosphorus; Rep, replicate sample; USGS, U.S. Geological Survey; - , no data; <, less than; ${ }^{\circ} \mathrm{C}$, degree Celsius; $\mu \mathrm{S} / \mathrm{cm}$, microsiemen per centimeter at $\left.25^{\circ} \mathrm{C}\right]$

\begin{tabular}{|c|c|c|c|c|c|c|c|c|c|c|c|}
\hline $\begin{array}{c}\text { USGS site } \\
\text { identification } \\
\text { number }\end{array}$ & $\begin{array}{l}\text { Site } \\
\text { short } \\
\text { name }\end{array}$ & $\begin{array}{c}\text { Date } \\
\text { (mm/dd/yyyy) }\end{array}$ & $\begin{array}{c}\text { Time } \\
\text { (hhmm) }\end{array}$ & $\begin{array}{c}\text { Sample } \\
\text { type }\end{array}$ & $\begin{array}{c}\text { Total ammonia plus } \\
\text { organic nitrogen } \\
\text { (mg/L as } \mathrm{N} \text { ) }\end{array}$ & $\begin{array}{l}\text { Total organic } \\
\text { nitrogen } \\
\text { (mg/L as } \mathrm{N})\end{array}$ & $\begin{array}{c}\text { Dissolved nitrate } \\
\text { plus nitrite } \\
\text { (mg/L as N) }\end{array}$ & $\begin{array}{c}\text { Dissolved } \\
\text { ammonia } \\
\text { (mg/L as N) }\end{array}$ & $\begin{array}{l}\text { Dissolved } \\
\text { chloride } \\
\text { (mg/L) }\end{array}$ & $\begin{array}{c}\text { Total } \\
\text { phosphorus } \\
\text { (mg/L as P) }\end{array}$ & $\begin{array}{c}\text { Dissolved } \\
\text { orthophosphate } \\
\text { (mg/L as P) }\end{array}$ \\
\hline \multicolumn{12}{|c|}{ Groundwater sites 2010_-Continued } \\
\hline 385733119471503 & MRB6 & 09/08/2010 & 2100 & Env & 0.11 & E0.09 & $2.69 \mathrm{~d}$ & $\mathrm{E} 0.01 \mathrm{n}$ & 9.95 & 0.060 & 0.072 \\
\hline 385733119471503 & MRB6 & 09/08/2010 & 2105 & Rep & 0.11 & $<0.11$ & $2.66 \mathrm{~d}$ & $<0.02$ & 10.2 & 0.058 & 0.073 \\
\hline 385733119471503 & MRB6 & 09/08/2010 & 2300 & Env & E0.10 n & $<0.10$ & $2.60 \mathrm{~d}$ & $<0.02$ & 10.1 & 0.058 & 0.069 \\
\hline 385733119471503 & MRB6 & 09/09/2010 & 0100 & Env & 0.12 & E0.11 & $2.65 \mathrm{~d}$ & $\mathrm{E} 0.01 \mathrm{n}$ & 10.1 & 0.058 & 0.071 \\
\hline 385733119471503 & MRB6 & 09/09/2010 & 0300 & Env & 0.11 & $<0.11$ & $2.67 \mathrm{~d}$ & $<0.02$ & 10.3 & 0.055 & 0.069 \\
\hline 385733119471503 & MRB6 & 09/09/2010 & 0500 & Env & 0.12 & $<0.12$ & $2.68 \mathrm{~d}$ & $<0.02$ & 10.5 & 0.056 & 0.072 \\
\hline 385733119471503 & MRB6 & 09/09/2010 & 0700 & Env & 0.10 & $<0.10$ & $2.68 \mathrm{~d}$ & $<0.02$ & 10.4 & 0.056 & 0.070 \\
\hline 385733119471503 & MRB6 & 09/09/2010 & 0705 & Rep & 0.13 & $<0.13$ & $2.67 \mathrm{~d}$ & $<0.02$ & 10.5 & 0.057 & 0.071 \\
\hline 385733119471503 & MRB6 & 09/09/2010 & 0900 & Env & E0.09 n & E0.08 & $2.65 \mathrm{~d}$ & $\mathrm{E} 0.01 \mathrm{n}$ & 10.3 & 0.057 & 0.072 \\
\hline 385733119471503 & MRB6 & 09/09/2010 & 1100 & Env & 0.12 & $<0.12$ & $2.67 \mathrm{~d}$ & $<0.02$ & 10.3 & 0.054 & 0.069 \\
\hline 385733119471503 & MRB6 & $10 / 19 / 2010$ & 1520 & Env & 0.12 & 0.10 & $2.62 \mathrm{~d}$ & $0.01 \mathrm{n}$ & 11.6 & 0.056 & 0.071 \\
\hline 385755119473701 & DLB1 & $07 / 27 / 2010$ & 1100 & Env & 0.19 & $<0.19$ & 0.136 & $<0.02$ & 5.37 & 0.029 & 0.032 \\
\hline 385755119473701 & DLB1 & 09/07/2010 & 1130 & Env & 0.11 & $<0.11$ & 0.165 & $<0.02$ & 6.09 & 0.022 & 0.028 \\
\hline 385755119473701 & DLB1 & $10 / 19 / 2010$ & 1015 & Blank & $<0.05$ & $<0.05$ & $<0.008$ & $<0.01$ & $<0.06$ & $<0.004$ & $<0.004$ \\
\hline 385755119473701 & DLB1 & $10 / 19 / 2010$ & 1125 & Env & 0.11 & $<0.11$ & 0.232 & $<0.01$ & 6.86 & 0.022 & 0.030 \\
\hline 385755119473702 & DMS2 & 07/27/2010 & 1215 & Env & 0.19 & 0.13 & $\mathrm{E} 0.012 \mathrm{n}$ & 0.05 & 5.96 & 0.123 & 0.127 \\
\hline 385755119473702 & DMS2 & 09/07/2010 & 1200 & Env & 0.16 & E0.14 & $\mathrm{E} 0.011 \mathrm{n}$ & E0.02 n & 6.34 & 0.097 & 0.101 \\
\hline 385755119473702 & DMS2 & $10 / 19 / 2010$ & 1145 & Env & 0.11 & $<0.11$ & 0.099 & $<0.01$ & 6.68 & 0.094 & 0.104 \\
\hline 385755119473703 & DRB3 & $07 / 27 / 2010$ & 1300 & Env & 0.25 & 0.14 & $<0.016$ & 0.1 & 5.45 & 0.163 & 0.148 \\
\hline 385755119473703 & DRB3 & $07 / 27 / 2010$ & 1345 & Blank & $<0.10$ & $<0.10$ & $<0.016$ & $<0.02$ & $<0.12$ & $<0.008$ & $<0.008$ \\
\hline 385755119473703 & DRB3 & 09/07/2010 & 1215 & Env & 0.15 & 0.11 & $<0.016$ & 0.04 & 6.47 & 0.134 & 0.121 \\
\hline 385755119473703 & DRB3 & 09/07/2010 & 1220 & Rep & 0.36 & 0.31 & E0.008 n & 0.04 & 6.44 & 0.133 & 0.120 \\
\hline 385755119473703 & DRB3 & $10 / 19 / 2010$ & 1205 & Env & 0.10 & 0.09 & 0.015 bn & $0.02 \mathrm{n}$ & 6.69 & 0.105 & 0.101 \\
\hline 385755119473705 & DLB10 & 09/07/2010 & 1310 & Env & 0.18 & 0.15 & $<0.016$ & 0.03 & 12.9 & 0.100 & 0.104 \\
\hline 385755119473705 & DLB10 & $10 / 19 / 2010$ & 1310 & Env & 0.21 & 0.17 & $<0.008$ & 0.04 & 16.0 & 0.114 & 0.110 \\
\hline
\end{tabular}


Appendix 2. Field Measurements and Nutrient, Chloride, Dissolved Organic Carbon, and Isotope Concentrations in Stream and Groundwater Samples Collected Along the East Fork Carson River, 2012, Carson Valley, West-Central Nevada 
Table 2-1. Field measurements and nutrient, chloride, dissolved organic carbon, and isotope concentrations in stream and groundwater samples collected along the East Fork Carson River, 2012, Carson Valley, west-central Nevada.

[b, value extrapolated at low end; Blank, blank sample; d, sample was diluted; Env, environmental sample; hhmm, hour minute; mg/L, milligram per liter; mm/dd/yyyy, month/day/year; $\mathrm{n}$, below the reporting level but at or above the detection level; N, nitrogen; O, oxygen; P, phosphorus; Rep, replicate sample; USGS, U.S. Geological Survey; - , no data; $<$, less than; ${ }^{\circ} \mathrm{C}$, degree Celsius; $\mu \mathrm{S} / \mathrm{cm}$, microsiemen per centimeter at $\left.25^{\circ} \mathrm{C}\right]$

\begin{tabular}{|c|c|c|c|c|c|c|c|c|c|c|c|}
\hline $\begin{array}{c}\text { USGS site } \\
\text { identification } \\
\text { number }\end{array}$ & $\begin{array}{l}\text { Site short } \\
\text { name }\end{array}$ & $\begin{array}{c}\text { Date } \\
\text { (mm/dd/yyyy) }\end{array}$ & $\begin{array}{c}\text { Time } \\
\text { (hhmm) }\end{array}$ & $\begin{array}{c}\text { Sample } \\
\text { type }\end{array}$ & $\begin{array}{c}\text { Water } \\
\text { temperature } \\
\left({ }^{\circ} \mathrm{C}\right)\end{array}$ & $\begin{array}{c}\text { Air } \\
\text { temperature } \\
\left({ }^{\circ} \mathrm{C}\right)\end{array}$ & $\begin{array}{c}\text { Specific } \\
\text { conductance } \\
(\mu \mathrm{S} / \mathrm{cm})\end{array}$ & $\begin{array}{l}\text { Dissolved } \\
\text { oxygen } \\
\text { (mg/L) }\end{array}$ & $\begin{array}{l}\text { Dissolved oxygen } \\
\text { percent of } \\
\text { saturation }\end{array}$ & $\mathrm{pH}$ & $\begin{array}{c}\text { Total } \\
\text { nitrogen } \\
\text { (mg/L) }\end{array}$ \\
\hline \multicolumn{12}{|c|}{ Stream sites 2012} \\
\hline 385708119465604 & SUT & $07 / 31 / 2012$ & 1127 & Env & 19.5 & 26.5 & 233 & 10.2 & 132 & 8.0 & 1.10 \\
\hline 385708119465604 & SUT & $07 / 31 / 2012$ & 1132 & Rep & - & - & - & - & - & - & 1.10 \\
\hline 385708119465604 & SUT & $08 / 30 / 2012$ & 1215 & Env & 19.3 & 34 & 239 & 10.6 & 136 & 8.2 & 0.51 \\
\hline 385708119465604 & SUT & $09 / 27 / 2012$ & 1530 & Env & 19.7 & 28.5 & 274 & 8.9 & 116 & 8.3 & $<0.29$ \\
\hline 385733119471504 & SMT & $07 / 31 / 2012$ & 0913 & Env & 19.4 & 23 & 275 & 10.6 & 136 & 8.0 & 0.75 \\
\hline 385733119471504 & SMT & 08/30/2012 & 1020 & Env & 19.2 & 24 & 277 & 10.6 & 136 & 8.1 & 0.40 \\
\hline 385733119471504 & SMT & $09 / 27 / 2012$ & 1300 & Blank & - & - & 2 & - & - & - & $<0.08$ \\
\hline 385733119471504 & SMT & $09 / 27 / 2012$ & 1430 & Env & 20.4 & 28.5 & 316 & 11.6 & 153 & 8.2 & 0.42 \\
\hline 385733119471504 & SMT & $09 / 27 / 2012$ & 1440 & Rep & - & - & - & - & - & - & 0.43 \\
\hline 385755119473704 & SDT & $07 / 31 / 2012$ & 0820 & Env & 16.1 & 16.5 & 323 & 7.5 & 90 & 8.0 & 0.50 \\
\hline 385755119473704 & SDT & 08/30/2012 & 0810 & Env & 15.3 & 12 & 321 & 6.9 & 81 & 7.8 & 0.26 \\
\hline 385755119473704 & SDT & $09 / 27 / 2012$ & 1250 & Env & 19.8 & 28.5 & 373 & 14.2 & 184 & 8.4 & 0.43 \\
\hline \multicolumn{12}{|c|}{ Groundwater sites 2012} \\
\hline 385731119471401 & ULB2 & $08 / 03 / 2012$ & 1800 & Env & 12.7 & - & 344 & 0.6 & 7 & 6.9 & $<0.08$ \\
\hline 385731119471401 & ULB2 & $08 / 29 / 2012$ & 1330 & Env & 13.8 & - & 338 & 0.3 & 4 & 6.9 & $<0.08$ \\
\hline 385731119471401 & ULB2 & $09 / 26 / 2012$ & 1410 & Env & 13.3 & - & 346 & 0.6 & 6 & 6.8 & $<0.12$ \\
\hline 385731119471402 & UMS3 & $08 / 03 / 2012$ & 1625 & Env & 14.5 & - & 421 & 0.5 & 6 & 7.2 & $<0.40$ \\
\hline 385731119471402 & UMS3 & $08 / 29 / 2012$ & 1255 & Env & 15.1 & - & 428 & 0.3 & 3 & 7.2 & $<0.38$ \\
\hline 385731119471402 & UMS3 & $09 / 26 / 2012$ & 1315 & Env & 13.9 & - & 429 & 0.5 & 5 & 7.2 & 0.29 \\
\hline 385731119471402 & UMS3 & $09 / 26 / 2012$ & 1325 & Rep & - & - & - & - & - & - & $<0.29$ \\
\hline 385731119471403 & URB4 & $08 / 03 / 2012$ & 1445 & Env & 15.9 & - & 676 & 0.7 & 9 & 6.9 & 3.40 \\
\hline 385731119471403 & URB4 & $08 / 29 / 2012$ & 1210 & Env & 16.5 & - & 742 & 0.3 & 4 & 6.9 & 3.30 \\
\hline 385731119471403 & URB4 & $09 / 26 / 2012$ & 1200 & Env & 15.8 & - & 696 & 0.6 & 7 & 6.9 & 3.20 \\
\hline 385731119471403 & URB4 & $09 / 26 / 2012$ & 1210 & Rep & - & - & - & - & - & - & - \\
\hline 385731119471404 & URBFS5 & $08 / 03 / 2012$ & 1240 & Env & 18.5 & - & 890 & 1.2 & 16 & 6.9 & 3.00 \\
\hline 385731119471404 & URBFS5 & $08 / 29 / 2012$ & 1115 & Env & 19.1 & - & 936 & 0.6 & 8 & 6.8 & 2.80 \\
\hline 385731119471404 & URBFS5 & $08 / 29 / 2012$ & 1120 & Rep & - & - & - & - & - & - & 2.80 \\
\hline
\end{tabular}


Table 2-1. Field measurements and nutrient, chloride, dissolved organic carbon, and isotope concentrations in stream and groundwater samples collected along the East Fork Carson River, 2012, Carson Valley, west-central Nevada.-Continued

[b, value extrapolated at low end; Blank, blank sample; d, sample was diluted; Env, environmental sample; hhmm, hour minute; mg/L, milligram per liter; mm/dd/yyyy, month/day/year; n, below the reporting level but at or above the detection level; N, nitrogen; O, oxygen; P, phosphorus; Rep, replicate sample; USGS, U.S. Geological Survey; - , no data; <, less than; ${ }^{\circ} \mathrm{C}$, degree Celsius; $\mu$ S/cm, microsiemen per centimeter at $\left.25^{\circ} \mathrm{C}\right]$

\begin{tabular}{|c|c|c|c|c|c|c|c|c|c|c|c|}
\hline $\begin{array}{c}\text { USGS site } \\
\text { identification } \\
\text { number }\end{array}$ & $\begin{array}{l}\text { Site short } \\
\text { name }\end{array}$ & $\begin{array}{c}\text { Date } \\
\text { (mm/dd/yyyy) }\end{array}$ & $\begin{array}{c}\text { Time } \\
\text { (hhmm) }\end{array}$ & $\begin{array}{c}\text { Sample } \\
\text { type }\end{array}$ & $\begin{array}{c}\text { Water } \\
\text { temperature } \\
\left({ }^{\circ} \mathrm{C}\right) \\
\end{array}$ & $\begin{array}{c}\text { Air } \\
\text { temperature } \\
\left({ }^{\circ} \mathrm{C}\right)\end{array}$ & 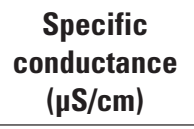 & $\begin{array}{c}\text { Dissolved } \\
\text { oxygen } \\
\text { (mg/L) } \\
\end{array}$ & $\begin{array}{c}\text { Dissolved oxygen } \\
\text { percent of } \\
\text { saturation }\end{array}$ & $\mathrm{pH}$ & $\begin{array}{c}\text { Total } \\
\text { nitrogen } \\
\text { (mg/L) }\end{array}$ \\
\hline \multicolumn{12}{|c|}{ Groundwater sites 2012-Continued } \\
\hline 385731119471404 & URBFS5 & $09 / 26 / 2012$ & 0945 & Blank & - & - & - & - & - & - & $<0.08$ \\
\hline 385731119471404 & URBFS5 & $09 / 26 / 2012$ & 1030 & Env & 18 & - & 906 & 0.8 & 10 & 6.8 & 2.90 \\
\hline 385733119471505 & MLB7 & $08 / 02 / 2012$ & 2000 & Env & 16.8 & - & 361 & 0.7 & 8 & 6.9 & $<0.13$ \\
\hline 385733119471505 & MLB7 & $08 / 29 / 2012$ & 0845 & Blank & - & - & - & - & - & - & $<0.08$ \\
\hline 385733119471505 & MLB7 & $08 / 29 / 2012$ & 0940 & Env & 19.4 & - & 340 & 0.4 & 5 & 7.1 & $<0.12$ \\
\hline 385733119471505 & MLB7 & $09 / 25 / 2012$ & 1455 & Env & 14.4 & - & 403 & 0.5 & 6 & 7.0 & $<0.15$ \\
\hline 385733119471506 & MMS8 & $08 / 2 / 2012$ & 1835 & Env & 19.3 & - & 320 & 0.5 & 6 & 7.1 & 0.11 \\
\hline 385733119471506 & MMS8 & $08 / 29 / 2012$ & 1020 & Env & 21.8 & - & 321 & 0.2 & 3 & 7.2 & $<0.10$ \\
\hline 385733119471506 & MMS8 & $09 / 25 / 2012$ & 1415 & Env & 17.4 & - & 390 & 0.5 & 6 & 7.2 & $<0.09$ \\
\hline 385733119471507 & MRB9 & 08/02/2012 & 1635 & Env & 18.7 & - & 337 & 0.5 & 6 & 7.0 & 0.73 \\
\hline 385733119471507 & MRB9 & $08 / 02 / 2012$ & 1640 & Rep & - & - & - & - & - & - & $<0.72$ \\
\hline 385733119471507 & MRB9 & $08 / 28 / 2012$ & 1505 & Env & 24.5 & - & 349 & 0.2 & 3 & 7.0 & $<0.20$ \\
\hline 385733119471507 & MRB9 & $09 / 25 / 2012$ & 1300 & Env & 17.1 & - & 352 & 0.3 & 4 & 7.2 & 0.85 \\
\hline 385733119471508 & MRBMFS10 & $08 / 02 / 2012$ & 1400 & Env & 20.8 & - & 774 & 1.0 & 13 & 6.9 & 2.70 \\
\hline 385733119471508 & MRBMFS10 & $08 / 28 / 2012$ & 1425 & Env & 29.2 & - & 780 & 0.2 & 4 & 6.9 & 2.50 \\
\hline 385733119471508 & MRBMFS10 & $09 / 25 / 2012$ & 1110 & Env & 19.3 & - & 759 & 0.8 & 10 & 7.0 & 3.00 \\
\hline 385733119471508 & MRBMFS10 & $09 / 25 / 2012$ & 1115 & Rep & - & - & - & - & - & - & 3.00 \\
\hline 385733119471510 & MRBFFS12 & $08 / 02 / 2012$ & 1200 & Env & 18.9 & - & 389 & 1.2 & 16 & 6.9 & $<0.44$ \\
\hline 385733119471510 & MRBFFS12 & $08 / 28 / 2012$ & 1335 & Env & 27.8 & - & 395 & 0.4 & 6 & 6.7 & $<0.57$ \\
\hline 385733119471510 & MRBFFS12 & $09 / 25 / 2012$ & 0955 & Env & 17.6 & - & 438 & 0.7 & 8 & 6.9 & $<0.53$ \\
\hline 385735119471501 & DLB14 & $08 / 04 / 2012$ & 1505 & Env & 16.5 & - & 410 & 0.7 & 9 & 6.9 & $<0.21$ \\
\hline 385735119471501 & DLB14 & $08 / 28 / 2012$ & 0900 & Blank & - & - & - & - & - & - & $<0.08$ \\
\hline 385735119471501 & DLB14 & $08 / 28 / 2012$ & 0955 & Env & 17.2 & - & 409 & 0.3 & 4 & 6.8 & $<0.23$ \\
\hline 385735119471501 & DLB14 & $09 / 24 / 2012$ & 1630 & Env & 16.4 & - & 386 & 0.5 & 6 & 7.0 & $<0.19$ \\
\hline 385735119471502 & DMS15 & $08 / 04 / 2012$ & 1255 & Env & 17.2 & - & 689 & 0.8 & 10 & 7.0 & 2.50 \\
\hline 385735119471502 & DMS15 & $08 / 28 / 2012$ & 1035 & Env & 18.8 & - & 693 & 0.5 & 6 & 7.0 & 2.30 \\
\hline 385735119471502 & DMS15 & $09 / 24 / 2012$ & 1530 & Env & 16.4 & - & 472 & 0.5 & 6 & 7.2 & 1.20 \\
\hline
\end{tabular}


Table 2-1. Field measurements and nutrient, chloride, dissolved organic carbon, and isotope concentrations in stream and groundwater samples collected along the East Fork Carson River, 2012, Carson Valley, west-central Nevada._-Continued

[b, value extrapolated at low end; Blank, blank sample; d, sample was diluted; Env, environmental sample; hhmm, hour minute; mg/L, milligram per liter; mm/dd/yyyy, month/day/year; $\mathrm{n}$, below the reporting level but at or above the detection level; N, nitrogen; O, oxygen; P, phosphorus; Rep, replicate sample; USGS, U.S. Geological Survey; —, no data; <, less than; ${ }^{\circ} \mathrm{C}$, degree Celsius; $\mu \mathrm{S} / \mathrm{cm}$, microsiemen per centimeter at $\left.25^{\circ} \mathrm{C}\right]$

\begin{tabular}{|c|c|c|c|c|c|c|c|c|c|c|c|c|}
\hline $\begin{array}{c}\text { USGS site } \\
\text { identification } \\
\text { number }\end{array}$ & $\begin{array}{l}\text { Site short } \\
\text { name }\end{array}$ & $\begin{array}{c}\text { Date } \\
\text { (mm/dd/yyyy) }\end{array}$ & $\begin{array}{c}\text { Time } \\
\text { (hhmm) }\end{array}$ & $\begin{array}{c}\text { Sample } \\
\text { type }\end{array}$ & $\begin{array}{c}\text { Water } \\
\text { temperature } \\
\left({ }^{\circ} \mathrm{C}\right)\end{array}$ & $\begin{array}{c}\text { Air } \\
\text { temperature } \\
\left({ }^{\circ} \mathrm{C}\right)\end{array}$ & $\begin{array}{c}\text { Specific } \\
\text { conductance } \\
(\mu \mathrm{S} / \mathrm{cm})\end{array}$ & $\begin{array}{r}\text { Dissolve } \\
\text { oxygen } \\
\text { (mg/L) }\end{array}$ & $\begin{array}{r}\text { Dissolv } \\
\text { per } \\
\text { satu }\end{array}$ & $\begin{array}{l}\text { Ied oxygen } \\
\text { cent of } \\
\text { uration }\end{array}$ & pH & $\begin{array}{c}\text { Total } \\
\text { nitrogen } \\
\text { (mg/L) }\end{array}$ \\
\hline \multicolumn{13}{|c|}{ Groundwater sites 2012-Continued } \\
\hline 385735119471503 & DRB16 & $08 / 04 / 2012$ & 1110 & Env & 17.2 & - & 744 & 0.9 & & 11 & 6.9 & 2.20 \\
\hline 385735119471503 & DRB16 & $08 / 28 / 2012$ & 1125 & Env & 23.5 & - & 751 & 0.2 & & 3 & 6.9 & 2.20 \\
\hline 385735119471503 & DRB16 & $09 / 24 / 2012$ & 1250 & Blank & - & - & - & - & & - & - & $<0.08$ \\
\hline 385735119471503 & DRB16 & $09 / 24 / 2012$ & 1420 & Env & 17.8 & - & 725 & 0.5 & & 7 & 7.0 & 2.20 \\
\hline 385735119471506 & DRBFS20 & $08 / 28 / 2012$ & 1225 & Env & 25.2 & - & 774 & 0.5 & & 8 & 6.9 & 2.50 \\
\hline 385735119471506 & DRBFS20 & $09 / 24 / 2012$ & 1140 & Env & 16.3 & - & 760 & 0.6 & & 7 & 7.0 & 2.50 \\
\hline $\begin{array}{c}\text { USGS site } \\
\text { identification } \\
\text { number }\end{array}$ & $\begin{array}{l}\text { Site short } \\
\text { name }\end{array}$ & $\begin{array}{c}\text { Date } \\
\text { (mm/dd/yyyy) }\end{array}$ & $\begin{array}{c}\text { Time } \\
\text { (hhmm) }\end{array}$ & $\begin{array}{c}\text { Sample } \\
\text { type }\end{array}$ & $\begin{array}{c}\text { Total ammonia } \\
\text { plus organic } \\
\text { nitrogen } \\
\text { (mg/L as } N \text { ) }\end{array}$ & $\begin{array}{c}\text { Total organic } \\
\text { nitrogen } \\
\text { (mg/L as N) }\end{array}$ & $\begin{array}{c}\text { Dissolved } \\
\text { nitrate plus } \\
\text { nitrite } \\
\text { (mg/L as N) }\end{array}$ & $\begin{array}{l}\text { Dissolved } \\
\text { nitrate } \\
\text { (mg/L as N) }\end{array}$ & $\begin{array}{l}\text { Dissolved } \\
\text { nitrite } \\
\text { (mg/L as N) }\end{array}$ & $\begin{array}{c}\text { Dissolved } \\
\text { ammonia } \\
\text { (mg/L as N) }\end{array}$ & $\begin{array}{c}\text { Dissolved } \\
\text { organic } \\
\text { carbon } \\
\text { (mg/L) }\end{array}$ & $\begin{array}{c}\text { Dissolved } \\
\text { chloride } \\
\text { (mg/L) }\end{array}$ \\
\hline \multicolumn{13}{|c|}{ Stream sites 2012-Continued } \\
\hline 385708119465604 & SUT & $07 / 31 / 2012$ & 1127 & Env & 0.29 & 0.28 & 0.86 & - & - & $0.01 \mathrm{n}$ & - & 4.23 \\
\hline 385708119465604 & SUT & $07 / 31 / 2012$ & 1132 & Rep & 0.26 & 0.25 & 0.86 & - & - & $0.01 \mathrm{n}$ & - & 4.24 \\
\hline 385708119465604 & SUT & $08 / 30 / 2012$ & 1215 & Env & 0.30 & $<0.30$ & 0.21 & - & - & $<0.01$ & - & 6.40 \\
\hline 385708119465604 & SUT & $09 / 27 / 2012$ & 1530 & Env & 0.28 & $<0.28$ & $<0.01$ & $<0.010$ & $<0.001$ & $<0.01$ & - & 9.41 \\
\hline 385733119471504 & SMT & $07 / 31 / 2012$ & 0913 & Env & 0.35 & 0.33 & 0.40 & 0.372 & 0.025 & $0.01 \mathrm{n}$ & - & 5.64 \\
\hline 385733119471504 & SMT & $08 / 30 / 2012$ & 1020 & Env & 0.30 & $<0.30$ & 0.10 & - & - & $<0.01$ & - & 7.33 \\
\hline 385733119471504 & SMT & $09 / 27 / 2012$ & 1300 & Blank & $<0.07$ & $<0.07$ & $<0.01$ & $<0.010$ & $<0.001$ & $<0.01$ & - & $<0.06$ \\
\hline 385733119471504 & SMT & $09 / 27 / 2012$ & 1430 & Env & 0.34 & $<0.34$ & 0.09 & 0.085 & 0.003 & $<0.01$ & $2.12 \mathrm{~b}$ & 9.16 \\
\hline 385733119471504 & SMT & $09 / 27 / 2012$ & 1440 & Rep & 0.34 & $<0.34$ & 0.09 & 0.085 & 0.002 & $<0.01$ & $2.33 \mathrm{~b}$ & 8.63 \\
\hline 385755119473704 & SDT & $07 / 31 / 2012$ & 0820 & Env & 0.33 & $<0.33$ & 0.17 & - & - & $<0.01$ & - & 7.17 \\
\hline 385755119473704 & SDT & $08 / 30 / 2012$ & 0810 & Env & 0.25 & $<0.25$ & $0.02 \mathrm{n}$ & - & - & $<0.01$ & - & 8.55 \\
\hline 385755119473704 & SDT & $09 / 27 / 2012$ & 1250 & Env & 0.39 & $<0.39$ & 0.04 & 0.035 & 0.003 & $<0.01$ & - & 10.60 \\
\hline \multicolumn{13}{|c|}{ Groundwater sites 2012-Continued } \\
\hline 385731119471401 & ULB2 & $08 / 03 / 2012$ & 1800 & Env & $<0.07$ & $<0.06$ & $<0.01$ & - & - & $0.01 \mathrm{n}$ & - & 4.90 \\
\hline 385731119471401 & ULB2 & $08 / 29 / 2012$ & 1330 & Env & $<0.07$ & $<0.06$ & $<0.01$ & - & - & $0.01 \mathrm{n}$ & - & 5.04 \\
\hline 385731119471401 & ULB2 & $09 / 26 / 2012$ & 1410 & Env & $0.11 \mathrm{n}$ & 0.09 & $<0.01$ & $<0.010$ & $<0.001$ & $0.01 \mathrm{n}$ & $1.19 \mathrm{~b}$ & 4.51 \\
\hline 385731119471402 & UMS3 & 08/03/2012 & 1625 & Env & $<0.07$ & $<0.07$ & 0.33 & - & - & $<0.01$ & - & 8.99 \\
\hline
\end{tabular}


Table 2-1. Field measurements and nutrient, chloride, dissolved organic carbon, and isotope concentrations in stream and groundwater samples collected along the East Fork Carson River, 2012, Carson Valley, west-central Nevada.-Continued

[b, value extrapolated at low end; Blank, blank sample; d, sample was diluted; Env, environmental sample; hhmm, hour minute; mg/L, milligram per liter; mm/dd/yyyy, month/day/year; n, below the reporting level but at or above the detection level; N, nitrogen; O, oxygen; P, phosphorus; Rep, replicate sample; USGS, U.S. Geological Survey; - , no data; <, less than; ${ }^{\circ} \mathrm{C}$, degree Celsius; $\mu \mathrm{S} / \mathrm{cm}$, microsiemen per centimeter at $\left.25^{\circ} \mathrm{C}\right]$

\begin{tabular}{|c|c|c|c|c|c|c|c|c|c|c|c|c|}
\hline $\begin{array}{c}\text { USGS site } \\
\text { identification } \\
\text { number }\end{array}$ & $\begin{array}{l}\text { Site short } \\
\text { name }\end{array}$ & $\begin{array}{c}\text { Date } \\
\text { (mm/dd/yyyy) }\end{array}$ & $\begin{array}{c}\text { Time } \\
\text { (hhmm) }\end{array}$ & $\begin{array}{l}\text { Sample } \\
\text { type }\end{array}$ & $\begin{array}{l}\text { Total ammonia } \\
\text { plus organic } \\
\text { nitrogen } \\
\text { (mg/L as } \mathrm{N} \text { ) }\end{array}$ & $\begin{array}{c}\text { Total organic } \\
\text { nitrogen } \\
\text { (mg/L as } \mathrm{N} \text { ) }\end{array}$ & $\begin{array}{c}\text { Dissolved } \\
\text { nitrate plus } \\
\text { nitrite } \\
\text { (mg/L as N) }\end{array}$ & $\begin{array}{l}\text { Dissolved } \\
\text { nitrate } \\
\text { (mg/L as N) }\end{array}$ & $\begin{array}{l}\text { Dissolved } \\
\text { nitrite } \\
\text { (mg/L as N) }\end{array}$ & $\begin{array}{l}\text { Dissolved } \\
\text { ammonia } \\
\text { (mg/L as N) }\end{array}$ & $\begin{array}{l}\text { Dissolved } \\
\text { organic } \\
\text { carbon } \\
\text { (mg/L) }\end{array}$ & $\begin{array}{c}\text { Dissolved } \\
\text { chloride } \\
\text { (mg/L) }\end{array}$ \\
\hline \multicolumn{13}{|c|}{ Groundwater sites 2012-Continued } \\
\hline 385731119471402 & UMS3 & $08 / 29 / 2012$ & 1255 & Env & $<0.07$ & $<0.05$ & 0.31 & - & - & $0.02 \mathrm{n}$ & - & 8.96 \\
\hline 385731119471402 & UMS3 & 09/26/2012 & 1315 & Env & $0.07 \mathrm{n}$ & $<0.07$ & 0.21 & 0.192 & 0.020 & $<0.01$ & $0.72 \mathrm{~b}$ & 9.56 \\
\hline 385731119471402 & UMS3 & 09/26/2012 & 1325 & Rep & $<0.07$ & $<0.07$ & 0.22 & 0.20 & 0.022 & $<0.01$ & $0.69 \mathrm{~b}$ & 9.53 \\
\hline 385731119471403 & URB4 & 08/03/2012 & 1445 & Env & $0.14 \mathrm{n}$ & $<0.14$ & $3.29 \mathrm{~d}$ & - & - & $<0.01$ & - & 15.70 \\
\hline 385731119471403 & URB4 & $08 / 29 / 2012$ & 1210 & Env & 0.15 & $<0.15$ & $3.14 \mathrm{~d}$ & - & - & $<0.01$ & - & 15.80 \\
\hline 385731119471403 & URB4 & 09/26/2012 & 1200 & Env & 0.22 & $<0.22$ & $3.01 \mathrm{~d}$ & 2.96 & 0.045 & $<0.01$ & $2.07 \mathrm{~b}$ & 15.50 \\
\hline 385731119471403 & URB4 & $09 / 26 / 2012$ & 1210 & Rep & - & - & - & - & - & - & - & - \\
\hline 385731119471404 & URBFS5 & 08/03/2012 & 1240 & Env & 0.27 & 0.26 & $2.72 \mathrm{~d}$ & 2.64 & 0.079 & $0.01 \mathrm{n}$ & - & 21.60 \\
\hline 385731119471404 & URBFS5 & 08/29/2012 & 1115 & Env & 0.25 & $<0.25$ & $2.54 \mathrm{~d}$ & - & - & $<0.01$ & - & 21.90 \\
\hline 385731119471404 & URBFS5 & $08 / 29 / 2012$ & 1120 & Rep & 0.29 & $<0.29$ & $2.52 \mathrm{~d}$ & - & - & $<0.01$ & - & 21.90 \\
\hline 385731119471404 & URBFS5 & 09/26/2012 & 0945 & Blank & $<0.07$ & $<0.07$ & $<0.01$ & $<0.010$ & $<0.001$ & $<0.01$ & $<0.23$ & $<0.06$ \\
\hline 385731119471404 & URBFS5 & $09 / 26 / 2012$ & 1030 & Env & 0.30 & $<0.30$ & $2.57 \mathrm{~d}$ & 2.51 & 0.057 & $<0.01$ & $3.46 \mathrm{~b}$ & 22.30 \\
\hline 385733119471505 & MLB7 & $08 / 02 / 2012$ & 2000 & Env & $0.12 \mathrm{n}$ & 0.08 & $<0.01$ & - & - & 0.03 & - & 7.18 \\
\hline 385733119471505 & MLB7 & $08 / 29 / 2012$ & 0845 & Blank & $<0.07$ & $<0.07$ & $<0.01$ & - & - & $<0.01$ & - & $<0.06$ \\
\hline 385733119471505 & MLB7 & $08 / 29 / 2012$ & 0940 & Env & $0.11 \mathrm{n}$ & 0.08 & $<0.01$ & - & - & 0.03 & - & 7.44 \\
\hline 385733119471505 & MLB7 & $09 / 25 / 2012$ & 1455 & Env & 0.14 & 0.11 & $<0.01$ & $<0.010$ & $<0.001$ & 0.04 & - & 4.82 \\
\hline 385733119471506 & MMS8 & $08 / 2 / 2012$ & 1835 & Env & $0.09 \mathrm{n}$ & $<0.09$ & 0.02 & - & - & $<0.01$ & - & 8.13 \\
\hline 385733119471506 & MMS8 & $08 / 29 / 2012$ & 1020 & Env & $0.09 \mathrm{n}$ & 0.07 & $<0.01$ & - & - & $0.02 \mathrm{n}$ & - & 6.78 \\
\hline 385733119471506 & MMS8 & $09 / 25 / 2012$ & 1415 & Env & $<0.07$ & $<0.06$ & $0.02 \mathrm{n}$ & 0.018 & 0.002 & $0.01 \mathrm{n}$ & - & 8.65 \\
\hline 385733119471507 & MRB9 & $08 / 02 / 2012$ & 1635 & Env & $0.07 \mathrm{n}$ & $<0.07$ & 0.66 & - & - & $<0.01$ & - & 6.34 \\
\hline 385733119471507 & MRB9 & $08 / 02 / 2012$ & 1640 & Rep & $<0.07$ & $<0.07$ & 0.65 & - & - & $<0.01$ & - & 6.34 \\
\hline 385733119471507 & MRB9 & $08 / 28 / 2012$ & 1505 & Env & 0.19 & $<0.19$ & $<0.01$ & - & - & $<0.01$ & - & 7.72 \\
\hline 385733119471507 & MRB9 & $09 / 25 / 2012$ & 1300 & Env & $0.11 \mathrm{n}$ & $<0.11$ & 0.74 & 0.669 & 0.069 & $<0.01$ & - & 6.31 \\
\hline 385733119471508 & MRBMFS10 & $08 / 02 / 2012$ & 1400 & Env & 0.21 & $<0.21$ & $2.47 \mathrm{~d}$ & 2.36 & 0.106 & $<0.01$ & - & 18.60 \\
\hline 385733119471508 & MRBMFS10 & $08 / 28 / 2012$ & 1425 & Env & 0.19 & $<0.19$ & $2.33 \mathrm{~d}$ & - & - & $<0.01$ & - & 18.10 \\
\hline 385733119471508 & MRBMFS10 & $09 / 25 / 2012$ & 1110 & Env & 0.17 & $<0.17$ & $2.79 \mathrm{~d}$ & 2.69 & 0.100 & $<0.01$ & $2.44 \mathrm{~b}$ & 18.30 \\
\hline 385733119471508 & MRBMFS10 & $09 / 25 / 2012$ & 1115 & Rep & 0.20 & $<0.20$ & $2.78 \mathrm{~d}$ & 2.68 & 0.104 & $<0.01$ & - & 18.20 \\
\hline
\end{tabular}


Table 2-1. Field measurements and nutrient, chloride, dissolved organic carbon, and isotope concentrations in stream and groundwater samples collected along the East Fork Carson River, 2012, Carson Valley, west-central Nevada.-Continued

[b, value extrapolated at low end; Blank, blank sample; d, sample was diluted; Env, environmental sample; hhmm, hour minute; mg/L, milligram per liter; mm/dd/yyyy, month/day/year; $\mathrm{n}$, below the reporting level but at or above the detection level; N, nitrogen; O, oxygen; P, phosphorus; Rep, replicate sample; USGS, U.S. Geological Survey; - , no data; <, less than; ${ }^{\circ} \mathrm{C}$, degree Celsius; $\mu \mathrm{S} / \mathrm{cm}$, microsiemen per centimeter at $\left.25^{\circ} \mathrm{C}\right]$

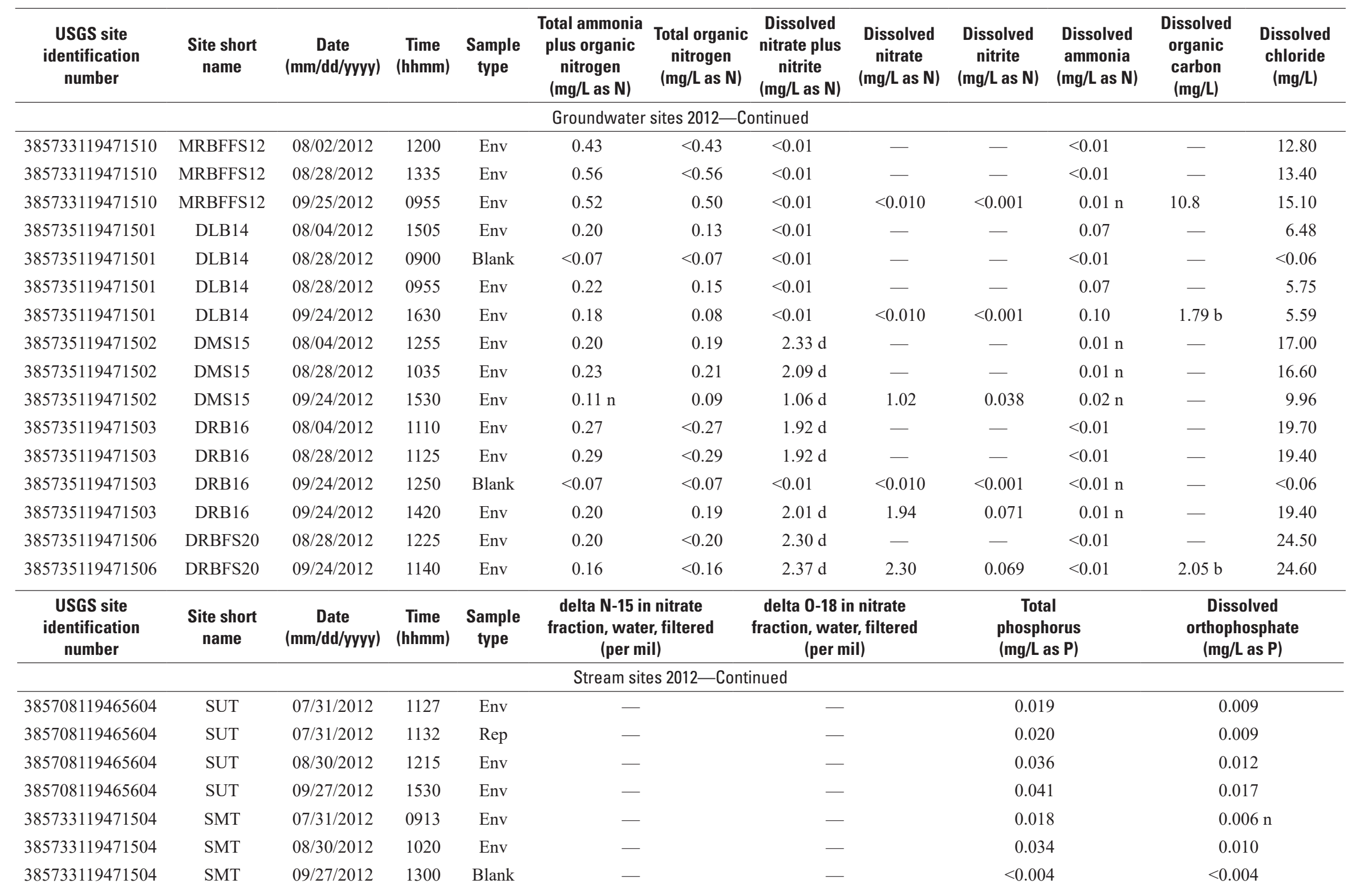


Table 2-1. Field measurements and nutrient, chloride, dissolved organic carbon, and isotope concentrations in stream and groundwater samples collected along the East Fork Carson River, 2012, Carson Valley, west-central Nevada.-Continued

[b, value extrapolated at low end; Blank, blank sample; d, sample was diluted; Env, environmental sample; hhmm, hour minute; mg/L, milligram per liter; mm/dd/yyyy, month/day/year; n, below the reporting level but at or above the detection level; N, nitrogen; O, oxygen; P, phosphorus; Rep, replicate sample; USGS, U.S. Geological Survey; - , no data; <, less than; ${ }^{\circ} \mathrm{C}$, degree Celsius; $\mu \mathrm{S} / \mathrm{cm}$, microsiemen per centimeter at $\left.25^{\circ} \mathrm{C}\right]$

\begin{tabular}{|c|c|c|c|c|c|c|c|c|}
\hline $\begin{array}{c}\text { USGS site } \\
\text { identification } \\
\text { number }\end{array}$ & $\begin{array}{l}\text { Site short } \\
\text { name }\end{array}$ & $\begin{array}{c}\text { Date } \\
\text { (mm/dd/yyyy) }\end{array}$ & $\begin{array}{c}\text { Time } \\
\text { (hhmm) }\end{array}$ & $\begin{array}{c}\text { Sample } \\
\text { type }\end{array}$ & $\begin{array}{c}\text { delta } \mathrm{N}-15 \text { in nitrate } \\
\text { fraction, water, filtered } \\
\text { (per mil) }\end{array}$ & $\begin{array}{c}\text { delta } 0-18 \text { in nitrate } \\
\text { fraction, water, filtered } \\
\text { (per mil) }\end{array}$ & $\begin{array}{c}\text { Total } \\
\text { phosphorus } \\
(\mathrm{mg} / \mathrm{L} \text { as } \mathrm{P})\end{array}$ & $\begin{array}{c}\text { Dissolved } \\
\text { orthophosphate } \\
\text { (mg/L as P) }\end{array}$ \\
\hline \multicolumn{9}{|c|}{ Stream sites 2012-Continued } \\
\hline 385733119471504 & SMT & 09/27/2012 & 1430 & Env & - & - & 0.044 & 0.014 \\
\hline 385733119471504 & SMT & 09/27/2012 & 1440 & Rep & - & - & 0.045 & 0.014 \\
\hline 385755119473704 & SDT & $07 / 31 / 2012$ & 0820 & Env & - & - & 0.020 & $0.005 \mathrm{n}$ \\
\hline 385755119473704 & SDT & $08 / 30 / 2012$ & 0810 & Env & - & - & 0.028 & $0.008 \mathrm{n}$ \\
\hline 385755119473704 & SDT & 09/27/2012 & 1250 & Env & - & - & 0.047 & 0.013 \\
\hline \multicolumn{9}{|c|}{ Groundwater sites 2012 - Continued } \\
\hline 385731119471401 & ULB2 & $08 / 03 / 2012$ & 1800 & Env & - & - & 0.061 & 0.010 \\
\hline 385731119471401 & ULB2 & $08 / 29 / 2012$ & 1330 & Env & - & - & 0.063 & 0.008 \\
\hline 385731119471401 & ULB2 & $09 / 26 / 2012$ & 1410 & Env & - & - & 0.064 & 0.012 \\
\hline 385731119471402 & UMS3 & $08 / 03 / 2012$ & 1625 & Env & - & - & 0.049 & 0.053 \\
\hline 385731119471402 & UMS3 & 08/29/2012 & 1255 & Env & - & - & 0.059 & 0.058 \\
\hline 385731119471402 & UMS3 & 09/26/2012 & 1315 & Env & 14.87 & 8.31 & 0.056 & 0.057 \\
\hline 385731119471402 & UMS3 & $09 / 26 / 2012$ & 1325 & Rep & - & - & 0.056 & 0.057 \\
\hline 385731119471403 & URB4 & 08/03/2012 & 1445 & Env & - & - & 0.066 & 0.073 \\
\hline 385731119471403 & URB4 & 08/29/2012 & 1210 & Env & - & - & 0.071 & 0.077 \\
\hline 385731119471403 & URB4 & 09/26/2012 & 1200 & Env & 13.66 & 5.33 & 0.074 & 0.084 \\
\hline 385731119471403 & URB4 & $09 / 26 / 2012$ & 1210 & Rep & 13.82 & 5.68 & - & - \\
\hline 385731119471404 & URBFS5 & $08 / 03 / 2012$ & 1240 & Env & - & - & 0.083 & 0.081 \\
\hline 385731119471404 & URBFS5 & $08 / 29 / 2012$ & 1115 & Env & - & - & 0.086 & 0.084 \\
\hline 385731119471404 & URBFS5 & 08/29/2012 & 1120 & Rep & - & - & 0.085 & 0.085 \\
\hline 385731119471404 & URBFS5 & $09 / 26 / 2012$ & 0945 & Blank & - & - & $<0.004$ & $<0.004$ \\
\hline 385731119471404 & URBFS5 & $09 / 26 / 2012$ & 1030 & Env & 21.6 & 8.90 & 0.080 & 0.078 \\
\hline 385733119471505 & MLB7 & $08 / 02 / 2012$ & 2000 & Env & - & - & 0.130 & 0.031 \\
\hline 385733119471505 & MLB7 & 08/29/2012 & 0845 & Blank & - & - & $<0.004$ & $<0.004$ \\
\hline 385733119471505 & MLB7 & $08 / 29 / 2012$ & 0940 & Env & - & - & 0.122 & 0.069 \\
\hline 385733119471505 & MLB7 & $09 / 25 / 2012$ & 1455 & Env & - & - & 0.123 & 0.029 \\
\hline 385733119471506 & MMS8 & $08 / 2 / 2012$ & 1835 & Env & - & - & 0.065 & 0.044 \\
\hline
\end{tabular}


Table 2-1. Field measurements and nutrient, chloride, dissolved organic carbon, and isotope concentrations in stream and groundwater samples collected along the East Fork Carson River, 2012, Carson Valley, west-central Nevada.-Continued

[b, value extrapolated at low end; Blank, blank sample; d, sample was diluted; Env, environmental sample; hhmm, hour minute; mg/L, milligram per liter; mm/dd/yyyy, month/day/year; $\mathrm{n}$, below the reporting level but at or above the detection level; N, nitrogen; O, oxygen; P, phosphorus; Rep, replicate sample; USGS, U.S. Geological Survey; —, no data; <, less than; ${ }^{\circ} \mathrm{C}$, degree Celsius; $\mu \mathrm{S} / \mathrm{cm}$, microsiemen per centimeter at $\left.25^{\circ} \mathrm{C}\right]$

\begin{tabular}{|c|c|c|c|c|c|c|c|c|}
\hline $\begin{array}{c}\text { USGS site } \\
\text { identification } \\
\text { number }\end{array}$ & $\begin{array}{l}\text { Site short } \\
\text { name }\end{array}$ & $\begin{array}{c}\text { Date } \\
\text { (mm/dd/yyyy) }\end{array}$ & $\begin{array}{c}\text { Time } \\
\text { (hhmm) }\end{array}$ & $\begin{array}{c}\text { Sample } \\
\text { type }\end{array}$ & $\begin{array}{l}\text { delta } \mathrm{N}-15 \text { in nitrate } \\
\text { fraction, water, filtered } \\
\text { (per mil) }\end{array}$ & $\begin{array}{c}\text { delta } \mathbf{0 - 1 8} \text { in nitrate } \\
\text { fraction, water, filtered } \\
\text { (per mil) }\end{array}$ & $\begin{array}{c}\text { Total } \\
\text { phosphorus } \\
\text { (mg/L as } \mathrm{P} \text { ) }\end{array}$ & $\begin{array}{c}\text { Dissolved } \\
\text { orthophosphate } \\
\text { (mg/L as P) }\end{array}$ \\
\hline \multicolumn{9}{|c|}{ Groundwater sites 2012-Continued } \\
\hline 385733119471506 & MMS8 & $08 / 29 / 2012$ & 1020 & Env & - & - & 0.058 & 0.048 \\
\hline 385733119471506 & MMS8 & $09 / 25 / 2012$ & 1415 & Env & - & - & 0.053 & 0.015 \\
\hline 385733119471507 & MRB9 & $08 / 02 / 2012$ & 1635 & Env & - & - & 0.053 & 0.052 \\
\hline 385733119471507 & MRB9 & $08 / 02 / 2012$ & 1640 & Rep & - & - & 0.053 & 0.053 \\
\hline 385733119471507 & MRB9 & $08 / 28 / 2012$ & 1505 & Env & - & - & 0.073 & 0.072 \\
\hline 385733119471507 & MRB9 & $09 / 25 / 2012$ & 1300 & Env & 30.36 & 11.11 & 0.046 & 0.046 \\
\hline 385733119471508 & MRBMFS 10 & $08 / 02 / 2012$ & 1400 & Env & - & - & 0.099 & 0.089 \\
\hline 385733119471508 & MRBMFS 10 & $08 / 28 / 2012$ & 1425 & Env & - & - & 0.101 & 0.098 \\
\hline 385733119471508 & MRBMFS10 & $09 / 25 / 2012$ & 1110 & Env & 18.57 & 7.36 & 0.099 & 0.100 \\
\hline 385733119471508 & MRBMFS10 & $09 / 25 / 2012$ & 1115 & Rep & - & - & 0.099 & 0.099 \\
\hline 385733119471510 & MRBFFS12 & $08 / 02 / 2012$ & 1200 & Env & - & - & $0.221 \mathrm{~d}$ & $0.205 \mathrm{~d}$ \\
\hline 385733119471510 & MRBFFS12 & $08 / 28 / 2012$ & 1335 & Env & - & - & $0.326 \mathrm{~d}$ & $0.296 \mathrm{~d}$ \\
\hline 385733119471510 & MRBFFS12 & $09 / 25 / 2012$ & 0955 & Env & - & - & $0.370 \mathrm{~d}$ & $0.339 \mathrm{~d}$ \\
\hline 385735119471501 & DLB14 & $08 / 04 / 2012$ & 1505 & Env & - & - & $0.208 \mathrm{~d}$ & 0.055 \\
\hline 385735119471501 & DLB14 & $08 / 28 / 2012$ & 0900 & Blank & - & - & $<0.004$ & $<0.004$ \\
\hline 385735119471501 & DLB14 & $08 / 28 / 2012$ & 0955 & Env & - & - & $0.216 \mathrm{~d}$ & 0.096 \\
\hline 385735119471501 & DLB14 & $09 / 24 / 2012$ & 1630 & Env & - & - & $0.251 \mathrm{~d}$ & 0.023 \\
\hline 385735119471502 & DMS15 & 08/04/2012 & 1255 & Env & - & - & 0.018 & 0.019 \\
\hline 385735119471502 & DMS15 & $08 / 28 / 2012$ & 1035 & Env & - & - & 0.025 & 0.015 \\
\hline 385735119471502 & DMS15 & 09/24/2012 & 1530 & Env & 30.29 & 12.88 & 0.018 & 0.019 \\
\hline 385735119471503 & DRB16 & 08/04/2012 & 1110 & Env & - & - & 0.124 & 0.123 \\
\hline 385735119471503 & DRB16 & $08 / 28 / 2012$ & 1125 & Env & - & - & 0.125 & 0.132 \\
\hline 385735119471503 & DRB16 & $09 / 24 / 2012$ & 1250 & Blank & - & - & $<0.004$ & $<0.004 \mathrm{n}$ \\
\hline 385735119471503 & DRB16 & 09/24/2012 & 1420 & Env & 19.5 & 8.35 & 0.126 & 0.131 \\
\hline 385735119471506 & DRBFS20 & $08 / 28 / 2012$ & 1225 & Env & - & - & 0.130 & 0.139 \\
\hline 385735119471506 & DRBFS20 & 09/24/2012 & 1140 & Env & 17.06 & 7.74 & 0.134 & 0.146 \\
\hline
\end{tabular}




\section{Appendix 3. Quality Assurance and Quality Control Procedures for Water- Quality Samples}

Quality control consisted of collection and analysis of split replicate samples and analysis of field blanks for surface water-quality and groundwater-quality samples. Quality control for groundwater and stream sampling consisted of the collection and analysis of (1) field blanks to check for potential contamination in environmental water samples from field and laboratory procedures and (2) split replicate samples to check for variability in environmental water samples owing to sample processing methods and laboratory analysis.

\section{Nutrient and Chloride Quality Control Samples}

During 2010, five groundwater and stream field blank samples were collected and had nitrate plus nitrite (hereafter referred to as nitrate), ammonia, dissolved chloride, total phosphorus, and orthophosphate concentrations less than the laboratory reporting limit (LRL). One stream field blank sample had a total Kjeldahl nitrogen (TKN, also referred to as total ammonia plus organic nitrogen) concentration of 0.05 milligrams per liter $(\mathrm{mg} / \mathrm{L})$ as nitrogen $(\mathrm{N})$, which is a value below the LRL but above the long-term method detection level (LTMDL). The rest of the field blanks had TKN concentrations below the LRLs.

During 2010, 12 groundwater and stream split replicate samples were collected. Using percent difference (the difference between two values divided by the average of the two values, shown as a percentage), three stream split replicate samples indicate good agreement between environmental and replicate samples for TKN, ammonia, nitrate, dissolved chloride, total phosphorus, and orthophosphate concentrations (12.5-percent difference or less). Nine split replicate groundwater samples indicate good agreement (10-percent difference or less) for all the parameters except TKN concentrations, where the percent differences in TKN values ranged from 0 to 82 percent. The median percent difference for the nine split replicate TKN samples was 13 percent. Six of nine split replicates for TKN were equal to or below 18-percent difference, but three split replicates had 25-, 26-, and 82-percent difference.

\section{Nutrient, Chloride, and Dissolved Organic Carbon Quality Control Samples}

During 2012, five groundwater and stream field blank samples were collected and had ammonia, nitrate, nitrite, TKN, total phosphorus, orthophosphate, chloride, and dissolved organic carbon (DOC) concentrations less than the LRL, indicating that the equipment used for these water samples was sufficiently cleaned between each use and that no sample contamination occurred from the equipment or methods used to collect and process the samples.

During 2012, seven groundwater and stream split replicate samples were collected. Two stream split replicate samples indicate good agreement (11-percent difference or less) between TKN, ammonia, nitrate, nitrite, total phosphorus, orthophosphate, chloride, and DOC concentrations in environmental and replicate samples in all but one case. In that case, the stream environmental sample had a nitrite concentration of $0.003 \mathrm{mg} / \mathrm{L}$ as $\mathrm{N}$ and the replicate was $0.002 \mathrm{mg} / \mathrm{L}$ as $\mathrm{N}$, giving a percent difference of 40 percent; however, these concentrations are very close to the LT-MDL of $0.001 \mathrm{mg} / \mathrm{L}$ as $\mathrm{N}$. When concentrations are close to the detection level, small differences in concentrations can translate to large percent differences. Four split replicate groundwater samples indicate good agreement (16-percent difference or less) between TKN, ammonia, nitrate, nitrite, total phosphorus, orthophosphate, chloride, and DOC concentrations in the environmental and replicate samples. Groundwater replicates for TKN ranged from 0 - to 16-percent difference, with a median of 13-percent difference.

\section{Dissolved-Gas and Nitrogen and Oxygen Isotope Quality Control Samples}

Two samples per observation well were collected for all dissolved-gas analysis. The percent differences for nitrogen gas $\left(\mathrm{N}_{2}\right)$ and argon gas (Ar) in environmental and replicate samples were small and ranged from 1 to 4 percent. One set of replicates was collected for the nitrogen and oxygen isotope samples and had percent differences of 1 and 6 percent for the nitrogen and oxygen samples, respectively. 


\section{Organic Wastewater Compounds Quality Control Samples}

Quality control for organic wastewater compound analyses included collection of one field blank and one split replicate. The split replicate sample and the environmental sample collected for observation well URBFS5 (fig. 6) had no detections of organic wastewater compounds (appendix 5). The field blank was collected the first day of sampling prior to the collection of the environmental sample at DRBFS20. The field blank was processed using laboratory-grade organic-free water in the same way as environmental sample, except that for the environmental sample a larger volume of well water passed through the Teflon tubing prior to hooking up to the filter plate compared to the amount of organic-free water that passed through the Teflon tubing prior to hooking it up to the filter plate. Similar amounts of water ran through the filter plate once the Teflon tubing was connected for both the blank and environmental samples. The field blank had detections of 7 out of 59 constituents analyzed (appendix 5). The field blank had two detections of compounds at concentrations higher than the LRL, one detection of a compound at a concentration higher than the LT-MDL but less than the LRL, and four detections of compounds at concentrations less than the LT-MDL.

The two detections in the field blank with concentrations that exceeded the LRL were for $N, N$-diethyl- $m$-toluamide (DEET; 0.09 micrograms per liter, $\mu \mathrm{g} / \mathrm{L}$ ) and phenol $(0.98 \mu \mathrm{g} / \mathrm{L})$. These detections were verified by the laboratory at these concentrations. DEET was detected in one environmental sample at a concentration $(0.86 \mu \mathrm{g} / \mathrm{L})$ well above the LRL $(0.06 \mathrm{ug} / \mathrm{L})$ and the concentration found in the field blank. A second environmental sample had a DEET concentration below the LT-MDL, but third and fourth environmental samples showed no DEET concentrations above the LRL. The only detection of phenol above the LRL was for the field blank. All phenol concentrations in environmental and replicate samples were below the LRL $(0.16 \mu \mathrm{g} / \mathrm{L})$. Given the precautions taken with personal care products, it is unclear when the contamination of the blank samples occurred, but the presence of these compounds in the field blank sample does not influence the analytical results or data interpretations with respect to the organic wastewater compounds.

The one detection in the field blank with a concentration greater than the LT-MDL but less than the LRL was for acetophenone. There were no detections of acetophenone in environmental and replicate samples. Acetophenone was noted as having been detected in the laboratory blank; therefore, it is possible that the contamination occurred at the laboratory. Acetophenone is used in fragrances, chewing gum, and as an additive to cigarettes. Similar to DEET, it is unclear where the contamination took place; however, its detection in the field blank sample did not influence the data obtained for environmental or replicate samples; all other concentrations of acetophenone were below the LRL $(0.4 \mu \mathrm{g} / \mathrm{L})$.

The four detections in the field blank with concentrations less than the LT-MDL were for benzophenone, methyl salicylate, beta-sitosterol, and beta-stigmastanol. Benzophenone and methyl salicylate were noted as having been detected in the laboratory blank, and it is possible that the contamination occurred at the laboratory. There were no detects of benzophenone and methyl salicylate in environmental and replicate samples. 
Appendix 4. Dissolved-Gas Concentrations, Assumed Recharge Elevation, Calculated Recharge Temperature, and Excess Air for Samples of Water From Select Groundwater Wells Located In and Near the East Fork Carson River, 2012, Carson Valley, West-Central Nevada 
Table 4-1. Dissolved-gas concentrations, assumed recharge elevation, calculated recharge temperature, and excess air for samples of water from select groundwater wells located in and near the East Fork Carson River, 2012, Carson Valley, west-central Nevada.

[Abbreviations: $\mathrm{cm}^{3} / \mathrm{L}$, cubic centimeter per liter; ft, foot; hhmm, hour minute; $\mathrm{mg} / \mathrm{L}$, milligram per liter; $\mathrm{mm} / \mathrm{dd} / \mathrm{yyy}$, month/day/year; $\mathrm{N}_{2}$, nitrogen gas; ${ }^{\circ} \mathrm{C}$, degree Celsius]

\begin{tabular}{|c|c|c|c|c|c|c|c|c|c|c|c|c|c|}
\hline \multirow{2}{*}{$\begin{array}{c}\text { Site } \\
\text { short name }\end{array}$} & \multirow{2}{*}{$\begin{array}{c}\text { Date } \\
\text { (mm/dd/yyyy) }\end{array}$} & \multirow{2}{*}{$\begin{array}{c}\text { Time } \\
\text { (hhmm) }\end{array}$} & \multicolumn{5}{|c|}{$\begin{array}{c}\text { Dissolved gases } \\
(\mathrm{mg} / \mathrm{L})\end{array}$} & \multicolumn{3}{|c|}{$\begin{array}{l}\text { Assumed recharge } \\
\text { (elevation } 8,500 \mathrm{ft} \text { ) }\end{array}$} & \multicolumn{3}{|c|}{$\begin{array}{l}\text { Assumed recharge } \\
\text { (elevation } 4,700 \mathrm{ft} \text { ) }\end{array}$} \\
\hline & & & Nitrogen & Argon & Oxygen & Methane & $\begin{array}{l}\text { Carbon } \\
\text { dioxide }\end{array}$ & $\begin{array}{c}\text { Recharge } \\
\text { temperature } \\
\left({ }^{\circ} \mathrm{C}\right)\end{array}$ & $\begin{array}{c}\text { Excess } \\
\text { air } \\
\left(\mathrm{cm}^{3} / \mathrm{L}\right)\end{array}$ & $\begin{array}{c}\text { Excess } \\
\mathrm{N}_{2} \\
(\mathrm{mg} / \mathrm{L})\end{array}$ & $\begin{array}{c}\text { Recharge } \\
\text { temperature } \\
\left({ }^{\circ} \mathrm{C}\right)\end{array}$ & $\begin{array}{c}\text { Excess } \\
\text { air } \\
\left(\mathrm{cm}^{3} / \mathrm{L}\right)\end{array}$ & $\begin{array}{c}\text { Excess } \\
\mathrm{N}_{2} \\
(\mathrm{mg} / \mathrm{L})\end{array}$ \\
\hline URBFS5 & $09 / 26 / 2012$ & 1031 & 15.99 & 0.541 & 0.2 & $<0.0010$ & 98.1 & 11.0 & 3.2 & 0 & 17.1 & 3.0 & 0 \\
\hline URBFS5 & 09/26/2012 & 1032 & 15.50 & 0.533 & 0.2 & $<0.0010$ & 104.3 & 11.0 & 2.7 & 0 & 17.1 & 2.4 & 0 \\
\hline URB4 & 09/26/2012 & 1201 & 17.39 & 0.584 & 0.2 & $<0.0010$ & 67.5 & 8.2 & 3.8 & 0 & 14.0 & 3.5 & 0 \\
\hline URB4 & 09/26/2012 & 1202 & 17.32 & 0.581 & 0.2 & $<0.0010$ & 66.0 & 8.5 & 3.8 & 0 & 14.3 & 3.5 & 0 \\
\hline URB4 duplicate & 09/26/2012 & 1203 & 17.24 & 0.580 & 0.2 & $<0.0010$ & 68.0 & 8.5 & 3.7 & 0 & 14.4 & 3.5 & 0 \\
\hline URB4 duplicate & 09/26/2012 & 1204 & 17.15 & 0.578 & 0.2 & $<0.0010$ & 67.0 & 8.6 & 3.6 & 0 & 14.4 & 3.4 & 0 \\
\hline UMS3 & 09/26/2012 & 1316 & 19.82 & 0.609 & 0.2 & $<0.0010$ & 21.4 & 10.6 & 7.0 & 0 & 16.6 & 6.7 & 0 \\
\hline UMS3 & 09/26/2012 & 1317 & 19.63 & 0.604 & 0.2 & 0.001 & 21.2 & 10.8 & 6.8 & 0 & 16.9 & 6.6 & 0 \\
\hline ULB2 & 09/26/2012 & 1411 & 18.69 & 0.632 & 0.2 & 0.003 & 43.0 & 5.0 & 4.0 & 0 & 10.5 & 3.7 & 0 \\
\hline ULB2 & 09/26/2012 & 1412 & 18.97 & 0.637 & 0.2 & 0.002 & 43.6 & 5.0 & 4.3 & 0 & 10.5 & 4.0 & 0 \\
\hline MRBFFS12 & $09 / 25 / 2012$ & 0956 & 16.23 & 0.539 & 0.2 & 0.041 & 52.7 & 12.0 & 3.7 & 0 & 18.2 & 3.4 & 0 \\
\hline MRBFFS12 & 09/25/2012 & 0957 & 16.43 & 0.544 & 0.2 & 0.039 & 53.3 & 11.8 & 3.8 & 0 & 17.9 & 3.6 & 0 \\
\hline MRBMFS 10 & 09/25/2012 & 1111 & 16.28 & 0.544 & 0.2 & 0.010 & 73.3 & 11.3 & 3.6 & 0 & 17.4 & 3.3 & 0 \\
\hline MRBMFS10 & $09 / 25 / 2012$ & 1112 & 16.23 & 0.543 & 0.2 & 0.010 & 73.7 & 11.3 & 3.5 & 0 & 17.4 & 3.3 & 0 \\
\hline MRB9 & $09 / 25 / 2012$ & 1301 & 18.61 & 0.596 & 0.2 & 0.014 & 23.4 & 9.5 & 5.4 & 0 & 15.4 & 5.1 & 0 \\
\hline MRB9 & $09 / 25 / 2012$ & 1302 & 18.43 & 0.595 & 0.2 & 0.013 & 24.5 & 9.2 & 5.1 & 0 & 15.1 & 4.9 & 0 \\
\hline MMS8 & $09 / 25 / 2012$ & 1416 & 17.96 & 0.575 & 0.2 & 0.016 & 22.8 & 10.9 & 5.2 & 0 & 17.0 & 4.9 & 0 \\
\hline MMS8 & $09 / 25 / 2012$ & 1417 & 18.24 & 0.580 & 0.2 & 0.026 & 24.0 & 10.9 & 5.4 & 0 & 17.0 & 5.2 & 0 \\
\hline MLB7 & $09 / 25 / 2012$ & 1456 & 18.91 & 0.633 & 0.2 & 0.006 & 46.8 & 5.4 & 4.3 & 0 & 10.9 & 4.1 & 0 \\
\hline MLB7 & $09 / 25 / 2012$ & 1457 & 19.09 & 0.637 & 0.2 & 0.007 & 47.7 & 5.3 & 4.5 & 0 & 10.8 & 4.3 & 0 \\
\hline DRBFS20 & 09/24/2012 & 1141 & 17.52 & 0.587 & 0.2 & $<0.0010$ & 65.8 & 8.2 & 3.9 & 0 & 14.0 & 3.7 & 0 \\
\hline DRBFS 20 & 09/24/2012 & 1142 & 17.47 & 0.585 & 0.2 & $<0.0010$ & 69.5 & 8.2 & 3.9 & 0 & 14.0 & 3.6 & 0 \\
\hline DRB16 & 09/24/2012 & 1421 & 16.79 & 0.560 & 0.2 & $<0.0010$ & 69.3 & 10.1 & 3.7 & 0 & 16.1 & 3.5 & 0 \\
\hline DRB16 & $09 / 24 / 2012$ & 1422 & 16.72 & 0.561 & 0.2 & $<0.0010$ & 69.0 & 9.9 & 3.6 & 0 & 15.9 & 3.4 & 0 \\
\hline DMS15 & 09/24/2012 & 1531 & 19.30 & 0.607 & 0.2 & $<0.0010$ & 32.2 & 9.7 & 6.2 & 0 & 15.6 & 5.9 & 0 \\
\hline DMS15 & $09 / 24 / 2012$ & 1532 & 20.24 & 0.624 & 0.2 & $<0.0010$ & 32.1 & 9.4 & 7.0 & 0 & 15.3 & 6.8 & 0 \\
\hline
\end{tabular}


Appendix 5. Organic Wastewater Compound Concentrations for Blank, Replicate, and Environmental Samples From Select Groundwater Wells Located In and Near the East Fork Carson River, 2012, Carson Valley, West-Central Nevada 
Table 5-1. Organic wastewater compound concentrations for blank, replicate, and environmental samples from select groundwater wells located in and near the East Fork Carson River, 2012, Carson Valley, west-central Nevada.

[Value in parentheses is the NWIS parameter code. Abbreviations: b, value extrapolated at low end; Blank, blank sample; E, estimated; Env, environmental sample; M, presence verified but not quantified; $\mathrm{m}$, value is highly variable by this method; $\mathrm{mm} / \mathrm{dd} / \mathrm{yyyy}$, month/day/year; $\mathrm{n}$, below the reporting level but at or above the detection level; Rep, replicate sample; $\mathrm{t}$, below the detection level; USGS, U.S. Geological Survey; v, analyte detected in laboratory blank; <, less than; $\mu \mathrm{g} / \mathrm{L}$, microgram per liter]

\begin{tabular}{|c|c|c|c|c|c|c|c|c|c|c|c|c|}
\hline $\begin{array}{c}\text { USGS site } \\
\text { identification } \\
\text { number }\end{array}$ & $\begin{array}{l}\text { Site short } \\
\text { name }\end{array}$ & $\begin{array}{c}\text { Date } \\
\text { (mm/dd/yyyy) }\end{array}$ & $\begin{array}{c}\text { Time } \\
\text { (hhmm) }\end{array}$ & $\begin{array}{l}\text { Sample } \\
\text { type }\end{array}$ & $\begin{array}{c}\text { 4-Cumylphenol } \\
(\mu \mathrm{g} / \mathrm{L}) \\
(62060)\end{array}$ & $\begin{array}{c}\text { 4-n- } \\
\text { Octylphenol } \\
(\mu \mathrm{g} / \mathrm{L}) \\
(62061)\end{array}$ & $\begin{array}{c}\text { 4-tert- } \\
\text { Octylphenol } \\
(\mu \mathrm{g} / \mathrm{L}) \\
(62062)\end{array}$ & $\begin{array}{l}\text { 4-Nonylphenol } \\
\text { diethoxylate } \\
\text { (sum of all } \\
\text { isomers) } \\
\text { ( } \mu \mathrm{g} / \mathrm{L}) \\
(62083)\end{array}$ & \multicolumn{2}{|c|}{$\begin{array}{c}\text { ol } \\
\text { e } \\
\text { (sum of all } \\
\text { isomers) } \\
(\mu \mathrm{g} / \mathrm{L}) \\
(62085)\end{array}$} & $\begin{array}{c}\text { 4-tert- } \\
\text { Octylphenol } \\
\text { diethoxylate } \\
(\mu \mathrm{g} / \mathrm{L}) \\
(61705)\end{array}$ & $\begin{array}{c}\text { 4-tert- } \\
\text { Octylphenol } \\
\text { onoethoxylate } \\
\text { ( } \mu \mathrm{g} / \mathrm{L}) \\
(61706)\end{array}$ \\
\hline 385735119471506 & DRBFS20 & 09/24/2012 & 1140 & Env & $<0.060$ & $<0.06 \mathrm{~m}$ & $<0.14 \mathrm{~m}$ & $<5.0 \mathrm{~m}$ & \multicolumn{2}{|c|}{$<2 \mathrm{~m}$} & $<1.0 \mathrm{~m}$ & $<1.0 \mathrm{~m}$ \\
\hline 385735119471506 & DRBFS20 & 09/24/2012 & 1235 & Blank & $<0.060$ & $<0.06 \mathrm{~m}$ & $<0.14 \mathrm{~m}$ & \multicolumn{3}{|l|}{$<5.0 \mathrm{~m}$} & $<1.0 \mathrm{~m}$ & $<1.0 \mathrm{~m}$ \\
\hline 385733119471510 & MRBFFS12 & $09 / 25 / 2012$ & 0955 & Env & $<0.060$ & $<0.06 \mathrm{~m}$ & $<0.14 \mathrm{~m}$ & $<5.0 \mathrm{~m}$ & \multicolumn{2}{|c|}{$<2 \mathrm{~m}$} & $<1.0 \mathrm{~m}$ & $<1.0 \mathrm{~m}$ \\
\hline 385733119471508 & MRBMFS10 & 09/25/2012 & 1110 & Env & $<0.060$ & $<0.06 \mathrm{~m}$ & $<0.14 \mathrm{~m}$ & \multicolumn{3}{|c|}{$<2 \mathrm{~m}$} & $<1.0 \mathrm{~m}$ & $<1.0 \mathrm{~m}$ \\
\hline 385731119471404 & URBFS5 & $09 / 26 / 2012$ & 1030 & Env & $<0.060$ & $<0.06 \mathrm{~m}$ & $<0.14 \mathrm{~m}$ & \multicolumn{3}{|c|}{$<2 \mathrm{~m}$} & $<1.0 \mathrm{~m}$ & $<1.0 \mathrm{~m}$ \\
\hline 385731119471404 & URBFS5 & $09 / 26 / 2012$ & 1040 & Rep & $<0.060$ & $<0.06 \mathrm{~m}$ & $<0.14 \mathrm{~m}$ & \multicolumn{3}{|c|}{$<2 \mathrm{~m}$} & $<1.0 \mathrm{~m}$ & $<1.0 \mathrm{~m}$ \\
\hline $\begin{array}{c}\text { USGS site } \\
\text { identification } \\
\text { number }\end{array}$ & $\begin{array}{l}\text { Site short } \\
\text { name }\end{array}$ & $\begin{array}{c}\text { Date } \\
\text { (mm/dd/yyyy) }\end{array}$ & $\begin{array}{c}\text { Time } \\
\text { (hhmm) }\end{array}$ & $\begin{array}{c}\text { Sample } \\
\text { type }\end{array}$ & $\begin{array}{c}\text { 3-Methyl- } \\
\text { 1H-indole } \\
\text { ( } \mu \mathrm{g} / \mathrm{L}) \\
(62058)\end{array}$ & $\begin{array}{l}\text { Acetophenone } \\
\text { ( } \mu \mathrm{g} / \mathrm{L}) \\
(62064)\end{array}$ & $\begin{array}{c}\text { Acetyl } \\
\text { hexamethyl } \\
\text { tetrahydro } \\
\text { naphthalene } \\
(\mu \mathrm{g} / \mathrm{L}) \\
(62065) \\
\end{array}$ & $\begin{array}{c}\text { Camphor } \\
(\mu \mathrm{g} / \mathrm{L}) \\
(62070)\end{array}$ & $\begin{array}{l}\text { Hexahydro- } \\
\text { hexamethyl } \\
\text { cyclopenta- } \\
\text { benzopyran } \\
\text { ( } \mathrm{gg} / \mathrm{L}) \\
(62075)\end{array}$ & $\begin{array}{c}\text { Indole } \\
(\mu \mathrm{g} / \mathrm{L}) \\
(62076)\end{array}$ & $\begin{array}{l}\text { Isoborneol } \\
(\mu \mathrm{g} / \mathrm{L}) \\
(62077)\end{array}$ & $\begin{array}{c}\text { Isoquinoline } \\
\text { ( } \mu \mathrm{g} / \mathrm{L}) \\
(62079)\end{array}$ \\
\hline 385735119471506 & DRBFS20 & $09 / 24 / 2012$ & 1140 & Env & $<0.036$ & $<0.4$ & $<0.028$ & $<0.044$ & $<0.052$ & $<0.08$ & $<0.08$ & $<0.046$ \\
\hline 385735119471506 & DRBFS20 & 09/24/2012 & 1235 & Blank & $<0.036$ & $0.3 \mathrm{vn}$ & $<0.028$ & $<0.044$ & $<0.052$ & $<0.08$ & $<0.08$ & $<0.046$ \\
\hline 385733119471510 & MRBFFS12 & 09/25/2012 & 0955 & Env & $<0.036$ & $<0.4$ & $<0.028$ & $<0.044$ & $<0.052$ & $<0.08$ & $<0.08$ & $<0.046$ \\
\hline 385733119471508 & MRBMFS10 & 09/25/2012 & 1110 & Env & $<0.036$ & $<0.4$ & $<0.028$ & $<0.044$ & $<0.052$ & $<0.08$ & $<0.08$ & $<0.046$ \\
\hline 385731119471404 & URBFS5 & 09/26/2012 & 1030 & Env & $<0.036$ & $<0.4$ & $<0.028$ & $<0.044$ & $<0.052$ & $<0.08$ & $<0.08$ & $<0.046$ \\
\hline 385731119471404 & URBFS5 & 09/26/2012 & 1040 & Rep & $<0.036$ & $<0.4$ & $<0.028$ & $<0.044$ & $<0.052$ & $<0.08$ & $<0.08$ & $<0.046$ \\
\hline $\begin{array}{c}\text { USGS site } \\
\text { identification } \\
\text { number }\end{array}$ & $\begin{array}{l}\text { Site short } \\
\text { name }\end{array}$ & $\begin{array}{c}\text { Date } \\
\text { (mm/dd/yyyy) }\end{array}$ & $\begin{array}{c}\text { Time } \\
\text { (hhmm) }\end{array}$ & $\begin{array}{l}\text { Sample } \\
\text { type }\end{array}$ & $\begin{array}{c}\text { Menthol } \\
(\mu \mathrm{g} / \mathrm{L}) \\
(62080)\end{array}$ & $\begin{array}{c}\text { 4-Dichlorobenzene } \\
(\mu \mathrm{g} / \mathrm{L}) \\
(34572) \\
\end{array}$ & $\begin{array}{c}\text { Bromacil } \\
(\mu \mathrm{g} / \mathrm{L}) \\
(04029) \\
\end{array}$ & $\begin{array}{c}\text { Carbaryl } \\
(\mu \mathrm{g} / \mathrm{L}) \\
(\mathbf{8 2 6 8 0})\end{array}$ & $\begin{array}{c}\text { Carbazole } \\
(\mu \mathrm{g} / \mathrm{L}) \\
(62071) \\
\end{array}$ & $\begin{array}{c}\text { Chlorpyrifos } \\
(\mu \mathrm{g} / \mathrm{L}) \\
(38933) \\
\end{array}$ & $\begin{array}{c}\text { D-Limonene } \\
(\mu \mathrm{g} / \mathrm{L}) \\
(62073) \\
\end{array}$ & $\begin{array}{c}\text { Diazinon } \\
(\mu \mathrm{g} / \mathrm{L}) \\
(39572)\end{array}$ \\
\hline 385735119471506 & DRBFS20 & $09 / 24 / 2012$ & 1140 & Env & $<0.32$ & $<0.040$ & $<0.36$ & $<0.16 \mathrm{~m}$ & $<0.030$ & $<0.16$ & $<0.08$ & $<0.16$ \\
\hline 385735119471506 & DRBFS20 & 09/24/2012 & 1235 & Blank & $<0.32$ & $<0.040$ & $<0.36$ & $<0.16 \mathrm{~m}$ & $<0.030$ & $<0.16$ & $<0.08$ & $<0.16$ \\
\hline 385733119471510 & MRBFFS12 & $09 / 25 / 2012$ & 0955 & Env & $<0.32$ & $<0.040$ & $<0.36$ & $<0.16 \mathrm{~m}$ & $<0.030$ & $<0.16$ & $<0.08$ & $<0.16$ \\
\hline 385733119471508 & MRBMFS10 & 09/25/2012 & 1110 & Env & $<0.32$ & $<0.040$ & $<0.36$ & $<0.16 \mathrm{~m}$ & $<0.030$ & $<0.16$ & $<0.08$ & $<0.16$ \\
\hline 385731119471404 & URBFS5 & $09 / 26 / 2012$ & 1030 & Env & $<0.32$ & $<0.040$ & $<0.36$ & $<0.16 \mathrm{~m}$ & $<0.030$ & $<0.16$ & $<0.08$ & $<0.16$ \\
\hline 385731119471404 & URBFS5 & 09/26/2012 & 1040 & Rep & $<0.32$ & $<0.040$ & $<0.36$ & $<0.16 \mathrm{~m}$ & $<0.030$ & $<0.16$ & $<0.08$ & $<0.16$ \\
\hline
\end{tabular}


Table 5-1. Organic wastewater compound concentrations for blank, replicate, and environmental samples from select groundwater wells located in and near the East Fork Carson River, 2012, Carson Valley, west-central Nevada.-Continued

[Value in parentheses is the NWIS parameter code. Abbreviations: b, value extrapolated at low end; Blank, blank sample; E, estimated; Env, environmental sample; M, presence verified but not quantified; $\mathrm{m}$, value is highly variable by this method; mm/dd/yyyy, month/day/year; $\mathrm{n}$, below the reporting level but at or above the detection level; Rep, replicate sample; $\mathrm{t}$, below the detection level; USGS, U.S. Geological Survey; v, analyte detected in laboratory blank; <, less than; $\mu \mathrm{g} / \mathrm{L}$, microgram per liter]

\begin{tabular}{|c|c|c|c|c|c|c|c|c|c|c|c|}
\hline $\begin{array}{c}\text { USGS site } \\
\text { identification } \\
\text { number }\end{array}$ & $\begin{array}{l}\text { Site short } \\
\text { name }\end{array}$ & $\begin{array}{c}\text { Date } \\
\text { (mm/dd/yyyy) }\end{array}$ & $\begin{array}{c}\text { Time } \\
\text { (hhmm) }\end{array}$ & $\begin{array}{c}\text { Sample } \\
\text { type }\end{array}$ & $\begin{array}{c}\text { Metalaxyl } \\
(\mu \mathrm{g} / \mathrm{L}) \\
(50359)\end{array}$ & $\begin{array}{c}\text { Metolachlor } \\
\text { ( } \mu \mathrm{g} / \mathrm{L}) \\
(39415)\end{array}$ & $\begin{array}{c}N, N \text {-Diethyl- } \\
m \text {-toluamide } \\
\text { (DEET) } \\
(\mu \mathrm{g} / \mathrm{L}) \\
(62082)\end{array}$ & $\begin{array}{l}\text { Prometon } \\
(\mu \mathrm{g} / \mathrm{L}) \\
(04037)\end{array}$ & $\begin{array}{c}\text { 5-Methyl-1H- } \\
\text { benzotriazole } \\
(\mu \mathrm{g} / \mathrm{L}) \\
(62063)\end{array}$ & $\begin{array}{l}\text { 10-Anthraquinone } \\
(\mu \mathrm{g} / \mathrm{L}) \\
(62066)\end{array}$ & $\begin{array}{c}\text { Benzophenone } \\
(\mu \mathrm{g} / \mathrm{L}) \\
(62067)\end{array}$ \\
\hline 385735119471506 & DRBFS20 & $09 / 24 / 2012$ & 1140 & Env & $<0.12$ & $<0.028$ & $\mathrm{E} 0.01 \mathrm{bt}$ & $<0.12$ & $<1.2$ & $<0.16 \mathrm{~m}$ & $<0.08$ \\
\hline 385735119471506 & DRBFS20 & $09 / 24 / 2012$ & 1235 & Blank & $<0.12$ & $<0.028$ & 0.09 & $<0.12$ & $<1.2$ & $<0.16 \mathrm{~m}$ & $0.03 \mathrm{vbt}$ \\
\hline 385733119471510 & MRBFFS12 & $09 / 25 / 2012$ & 0955 & Env & $<0.12$ & $<0.028$ & 0.86 & $0.03 \mathrm{bt}$ & $<1.2$ & $<0.16 \mathrm{~m}$ & $<0.08$ \\
\hline 385733119471508 & MRBMFS10 & $09 / 25 / 2012$ & 1110 & Env & $<0.12$ & $<0.028$ & $<0.06$ & $0.02 \mathrm{bt}$ & $<1.2$ & $<0.16 \mathrm{~m}$ & $<0.08$ \\
\hline 385731119471404 & URBFS5 & 09/26/2012 & 1030 & Env & $<0.12$ & $<0.028$ & $<0.06$ & $<0.12$ & $<1.2$ & $<0.16 \mathrm{~m}$ & $<0.08$ \\
\hline 385731119471404 & URBFS5 & $09 / 26 / 2012$ & 1040 & Rep & $<0.12$ & $<0.028$ & $<0.06$ & $<0.12$ & $<1.2$ & $<0.16 \mathrm{~m}$ & $<0.08$ \\
\hline $\begin{array}{c}\text { USGS site } \\
\text { identification } \\
\text { number }\end{array}$ & $\begin{array}{l}\text { Site short } \\
\text { name }\end{array}$ & $\begin{array}{c}\text { Date } \\
\text { (mm/dd/yyyy) }\end{array}$ & $\begin{array}{c}\text { Time } \\
\text { (hhmm) }\end{array}$ & $\begin{array}{c}\text { Sample } \\
\text { type }\end{array}$ & $\begin{array}{l}\text { Isophorone } \\
(\mu \mathrm{g} / \mathrm{L}) \\
(34409)\end{array}$ & $\begin{array}{c}\text { Isopropylbenzen } \\
(\mu \mathrm{g} / \mathrm{L}) \\
(\mathbf{6 2 0 7 8})\end{array}$ & $\begin{array}{c}\text { Methyl } \\
\text { salicylate } \\
(\mu \mathrm{g} / \mathrm{L}) \\
(\mathbf{6 2 0 8 1 )}\end{array}$ & $\begin{array}{c}p \text {-Cresol } \\
(\mu \mathrm{g} / \mathrm{L}) \\
(\mathbf{6 2 0 8 4})\end{array}$ & $\begin{array}{c}\text { Tetrachloroethene } \\
(\mu \mathrm{g} / \mathrm{L}) \\
(34476)\end{array}$ & $\begin{array}{l}\text { Triethyl } \\
\text { citrate } \\
(\mu \mathrm{g} / \mathrm{L}) \\
(\mathbf{6 2 0 9 1 )}\end{array}$ & $\begin{array}{l}\text { ibromomethane } \\
\text { ( } \mu \mathrm{g} / \mathrm{L}) \\
(34288)\end{array}$ \\
\hline 385735119471506 & DRBFS20 & $09 / 24 / 2012$ & 1140 & Env & $<0.032$ & $<0.30$ & $<0.044$ & $<0.08$ & $<0.12 \mathrm{~m}$ & $<0.16$ & $<0.10$ \\
\hline 385735119471506 & DRBFS20 & 09/24/2012 & 1235 & Blank & $<0.032$ & $<0.30 \mathrm{v}$ & $0.016 \mathrm{vbt}$ & $<0.08$ & $<0.12 \mathrm{~m}$ & $<0.16$ & $<0.10$ \\
\hline 385733119471510 & MRBFFS12 & $09 / 25 / 2012$ & 0955 & Env & $<0.032$ & $<0.30$ & $<0.044$ & $<0.08$ & $<0.12 \mathrm{~m}$ & $<0.16$ & $<0.10$ \\
\hline 385733119471508 & MRBMFS10 & $09 / 25 / 2012$ & 1110 & Env & $<0.032$ & $<0.30$ & $<0.044$ & $<0.08$ & $<0.12 \mathrm{~m}$ & $<0.16$ & $<0.10$ \\
\hline 385731119471404 & URBFS5 & $09 / 26 / 2012$ & 1030 & Env & $<0.032$ & $<0.30$ & $<0.044$ & $<0.08$ & $<0.12 \mathrm{~m}$ & $<0.16$ & $<0.10$ \\
\hline 385731119471404 & URBFS5 & $09 / 26 / 2012$ & 1040 & Rep & $<0.032$ & $<0.30$ & $<0.044$ & $<0.08$ & $<0.12 \mathrm{~m}$ & $<0.16$ & $<0.10$ \\
\hline $\begin{array}{c}\text { USGS site } \\
\text { identification } \\
\text { number }\end{array}$ & $\begin{array}{l}\text { Site short } \\
\text { name }\end{array}$ & $\begin{array}{c}\text { Date } \\
\text { (mm/dd/yyyy) }\end{array}$ & $\begin{array}{c}\text { Time } \\
\text { (hhmm) }\end{array}$ & $\begin{array}{c}\text { Sample } \\
\text { type }\end{array}$ & $\begin{array}{c}\text { Phenol } \\
(\mu g / L) \\
(34466)\end{array}$ & $\begin{array}{c}\text { Triclosan } \\
(\mu \mathrm{g} / \mathrm{L}) \\
(62090)\end{array}$ & $\begin{array}{l}\text { ethylnaphthalene } \\
(\mu \mathrm{g} / \mathrm{L}) \\
(62054)\end{array}$ & \multicolumn{2}{|c|}{$\begin{array}{c}\text { 2,6-Dimethylnaphthalene } \\
(\mu \mathrm{g} / \mathrm{L}) \\
(62055)\end{array}$} & $\begin{array}{c}\text {-Methylnaphthalene } \\
(\mu \mathrm{g} / \mathrm{L}) \\
(62056)\end{array}$ & $\begin{array}{c}\text { Anthracene } \\
(\mu \mathrm{g} / \mathrm{L}) \\
(34221) \\
\end{array}$ \\
\hline 385735119471506 & DRBFS20 & $09 / 24 / 2012$ & 1140 & Env & $<0.16$ & $<0.20$ & $<0.022$ & \multicolumn{2}{|r|}{$<0.06$} & $<0.036$ & $<0.010$ \\
\hline 385735119471506 & DRBFS20 & $09 / 24 / 2012$ & 1235 & Blank & 0.98 & $<0.20$ & $<0.022$ & \multicolumn{2}{|r|}{$<0.06$} & $<0.036$ & $<0.010$ \\
\hline 385733119471510 & MRBFFS12 & $09 / 25 / 2012$ & 0955 & Env & $<0.16$ & $<0.20$ & $<0.022$ & \multicolumn{2}{|r|}{$<0.06$} & $<0.036$ & $<0.010$ \\
\hline 385733119471508 & MRBMFS10 & $09 / 25 / 2012$ & 1110 & Env & $<0.16$ & $<0.20$ & $<0.022$ & \multicolumn{2}{|r|}{$<0.06$} & $<0.036$ & $<0.010$ \\
\hline 385731119471404 & URBFS5 & $09 / 26 / 2012$ & 1030 & Env & $<0.16$ & $<0.20$ & $<0.022$ & \multicolumn{2}{|r|}{$<0.06$} & $<0.036$ & $<0.010$ \\
\hline 385731119471404 & URBFS5 & 09/26/2012 & 1040 & Rep & $<0.16$ & $<0.20$ & $<0.022$ & \multicolumn{2}{|r|}{$<0.06$} & $<0.036$ & $<0.010$ \\
\hline
\end{tabular}


Table 5-1. Organic wastewater compound concentrations for blank, replicate, and environmental samples from select groundwater wells located in and near the East Fork Carson River, 2012, Carson Valley, west-central Nevada.-Continued

[Value in parentheses is the NWIS parameter code. Abbreviations: b, value extrapolated at low end; Blank, blank sample; E, estimated; Env, environmental sample; M, presence verified but not quantified; $\mathrm{m}$, value is highly variable by this method; $\mathrm{mm} / \mathrm{dd} / \mathrm{yyyy}$, month/day/year; $\mathrm{n}$, below the reporting level but at or above the detection level; Rep, replicate sample; $\mathrm{t}$, below the detection level; USGS, U.S. Geological Survey; v, analyte detected in laboratory blank; <, less than; $\mu \mathrm{g} / \mathrm{L}$, microgram per liter]

\begin{tabular}{|c|c|c|c|c|c|c|c|c|c|c|c|c|}
\hline $\begin{array}{c}\text { USGS site } \\
\text { identification } \\
\text { number }\end{array}$ & $\begin{array}{l}\text { Site short } \\
\text { name }\end{array}$ & $\begin{array}{c}\text { Date } \\
\text { (mm/dd/yyyy) }\end{array}$ & $\begin{array}{c}\text { Time } \\
\text { (hhmm) }\end{array}$ & $\begin{array}{l}\text { Sample } \\
\text { type }\end{array}$ & $\begin{array}{c}\text { Benzo[a] } \\
\text { pyrene } \\
(\mu \mathrm{g} / \mathrm{L}) \\
(\mathbf{3 4 2 4 8 )}\end{array}$ & $\begin{array}{c}\text { Fluoranthene } \\
(\mu \mathrm{g} / \mathrm{L}) \\
(34377)\end{array}$ & $\begin{array}{c}\text { Naphthalene } \\
(\mu \mathrm{g} / \mathrm{L}) \\
(34443)\end{array}$ & $\begin{array}{c}\text { Phenanthrene } \\
(\mu \mathrm{g} / \mathrm{L}) \\
(34462)\end{array}$ & $\begin{array}{c}\text { Pyrene } \\
\text { ( } \mu \mathrm{g} / \mathrm{L}) \\
(34470)\end{array}$ & $\begin{array}{cc}\text { Tris(2- } & \\
\text { chloroethyl) } & \mathrm{T} \\
\text { phosphate } & \mathrm{pr} \\
(\mu \mathrm{g} / \mathrm{L}) & \\
(62087) & \end{array}$ & $\begin{array}{l}\text { Tris(dichloroiso- } \\
\text { propyl) phosphate } \\
\text { ( } \mu \mathrm{g} / \mathrm{L}) \\
(62088)\end{array}$ & $\begin{array}{c}\text { Tributyl } \\
\text { phosphate } \\
\text { ( } \mu \mathrm{g} / \mathrm{L}) \\
(62089)\end{array}$ \\
\hline 385735119471506 & DRBFS20 & $09 / 24 / 2012$ & 1140 & Env & $<0.06$ & $<0.024$ & $<0.040$ & $<0.016$ & $<0.042$ & $<0.10$ & $<0.16$ & $<0.16$ \\
\hline 385735119471506 & DRBFS20 & 09/24/2012 & 1235 & Blank & $<0.06$ & $<0.024$ & $<0.040$ & $<0.016$ & $<0.042$ & $<0.10$ & $<0.16$ & $<0.16$ \\
\hline 385733119471510 & MRBFFS12 & $09 / 25 / 2012$ & 0955 & Env & $<0.06$ & $<0.024$ & $<0.040$ & $<0.016$ & $<0.042$ & $0.03 \mathrm{bt}$ & $0.13 \mathrm{n}$ & $<0.16$ \\
\hline 385733119471508 & MRBMFS10 & 09/25/2012 & 1110 & Env & $<0.06$ & $<0.024$ & $<0.040$ & $<0.016$ & $<0.042$ & $<0.10$ & $<0.16$ & $<0.16$ \\
\hline 385731119471404 & URBFS5 & 09/26/2012 & 1030 & Env & $<0.06$ & $<0.024$ & $<0.040$ & $<0.016$ & $<0.042$ & $<0.10$ & $<0.16$ & $<0.16$ \\
\hline 385731119471404 & URBFS5 & $09 / 26 / 2012$ & 1040 & Rep & $<0.06$ & $<0.024$ & $<0.040$ & $<0.016$ & $<0.042$ & $<0.10$ & $<0.16$ & $<0.16$ \\
\hline $\begin{array}{c}\text { USGS site } \\
\text { identification } \\
\text { number }\end{array}$ & $\begin{array}{l}\text { Site short } \\
\text { name }\end{array}$ & $\begin{array}{c}\text { Date } \\
\text { (mm/dd/yyyy) }\end{array}$ & $\begin{array}{c}\text { Time } \\
\text { (hhmm) }\end{array}$ & $\begin{array}{l}\text { Sample } \\
\text { type }\end{array}$ & $\begin{array}{c}\text { Triphenyl } \\
\text { phosphate } \\
(\mu \mathrm{g} / \mathrm{L}) \\
(62092)\end{array}$ & $\begin{array}{c}\text { Tris(2- } \\
\text { butoxyethyl) } \\
\text { phosphate } \\
(\mu \mathrm{g} / \mathrm{L}) \\
(62093)\end{array}$ & $\begin{array}{c}\text { beta- } \\
\text { Sitosterol } \\
(\mu \mathrm{g} / \mathrm{L}) \\
(\mathbf{6 2 0 6 8 )}\end{array}$ & $\begin{array}{c}\text { beta- } \\
\text { Stigmastanol } \\
(\mu \mathrm{g} / \mathrm{L}) \\
(\mathbf{6 2 0 8 6 )}\end{array}$ & $\begin{array}{c}\text { Cholesterol } \\
(\mu \mathrm{g} / \mathrm{L}) \\
(62072)\end{array}$ & $\begin{array}{c}\text { 3-beta- } \\
\text { Coprostanol } \\
(\mu \mathrm{g} / \mathrm{L}) \\
(62057)\end{array}$ & $\begin{array}{c}\text { Caffeine } \\
\text { ( } \mu \mathrm{g} / \mathrm{L}) \\
(50305)\end{array}$ & $\begin{array}{c}\text { Cotinine } \\
\text { ( } \mu \mathrm{g} / \mathrm{L}) \\
(62005)\end{array}$ \\
\hline 385735119471506 & DRBFS20 & $09 / 24 / 2012$ & 1140 & Env & $<0.12$ & $<0.8$ & $\mathrm{M} \mathrm{mt}$ & $<2.6 \mathrm{~m}$ & $<2.0 \mathrm{~m}$ & $<1.8 \mathrm{~m}$ & $<0.06$ & $<0.800 \mathrm{~m}$ \\
\hline 385735119471506 & DRBFS20 & $09 / 24 / 2012$ & 1235 & Blank & $<0.12$ & $<0.8$ & $\mathrm{M} \mathrm{mt}$ & $\mathrm{E} 0.3 \mathrm{mt}$ & $<2.0 \mathrm{~m}$ & $<1.8 \mathrm{~m}$ & $<0.06$ & $<0.800 \mathrm{~m}$ \\
\hline 385733119471510 & MRBFFS12 & $09 / 25 / 2012$ & 0955 & Env & $<0.12$ & $\mathrm{E} 0.4 \mathrm{t}$ & $<4 \mathrm{~m}$ & E0.4 mt & $\mathrm{E} 0.2 \mathrm{mt}$ & $<1.8 \mathrm{~m}$ & $<0.06$ & $<0.800 \mathrm{~m}$ \\
\hline 385733119471508 & MRBMFS10 & $09 / 25 / 2012$ & 1110 & Env & $<0.12$ & $<0.8$ & $<4 \mathrm{~m}$ & $<2.6 \mathrm{~m}$ & $<2.0 \mathrm{~m}$ & $<1.8 \mathrm{~m}$ & $<0.06$ & $<0.800 \mathrm{~m}$ \\
\hline 385731119471404 & URBFS5 & $09 / 26 / 2012$ & 1030 & Env & $<0.12$ & $<0.8$ & $<4 \mathrm{~m}$ & $<2.6 \mathrm{~m}$ & $<2.0 \mathrm{~m}$ & $<1.8 \mathrm{~m}$ & $<0.06$ & $<0.800 \mathrm{~m}$ \\
\hline 385731119471404 & URBFS5 & $09 / 26 / 2012$ & 1040 & Rep & $<0.12$ & $<0.8$ & $<4 \mathrm{~m}$ & $<2.6 \mathrm{~m}$ & $<2.0 \mathrm{~m}$ & $<1.8 \mathrm{~m}$ & $<0.06$ & $<0.800 \mathrm{~m}$ \\
\hline
\end{tabular}


Publishing support provided by the U.S. Geological Survey Science Publishing Network, Sacramento Publishing Service Center

For more information concerning the research in this report, contact the Nevada Water Science Center

U.S. Geological Survey

2730 N. Deer Run Rd.

Carson City, NV 89701 

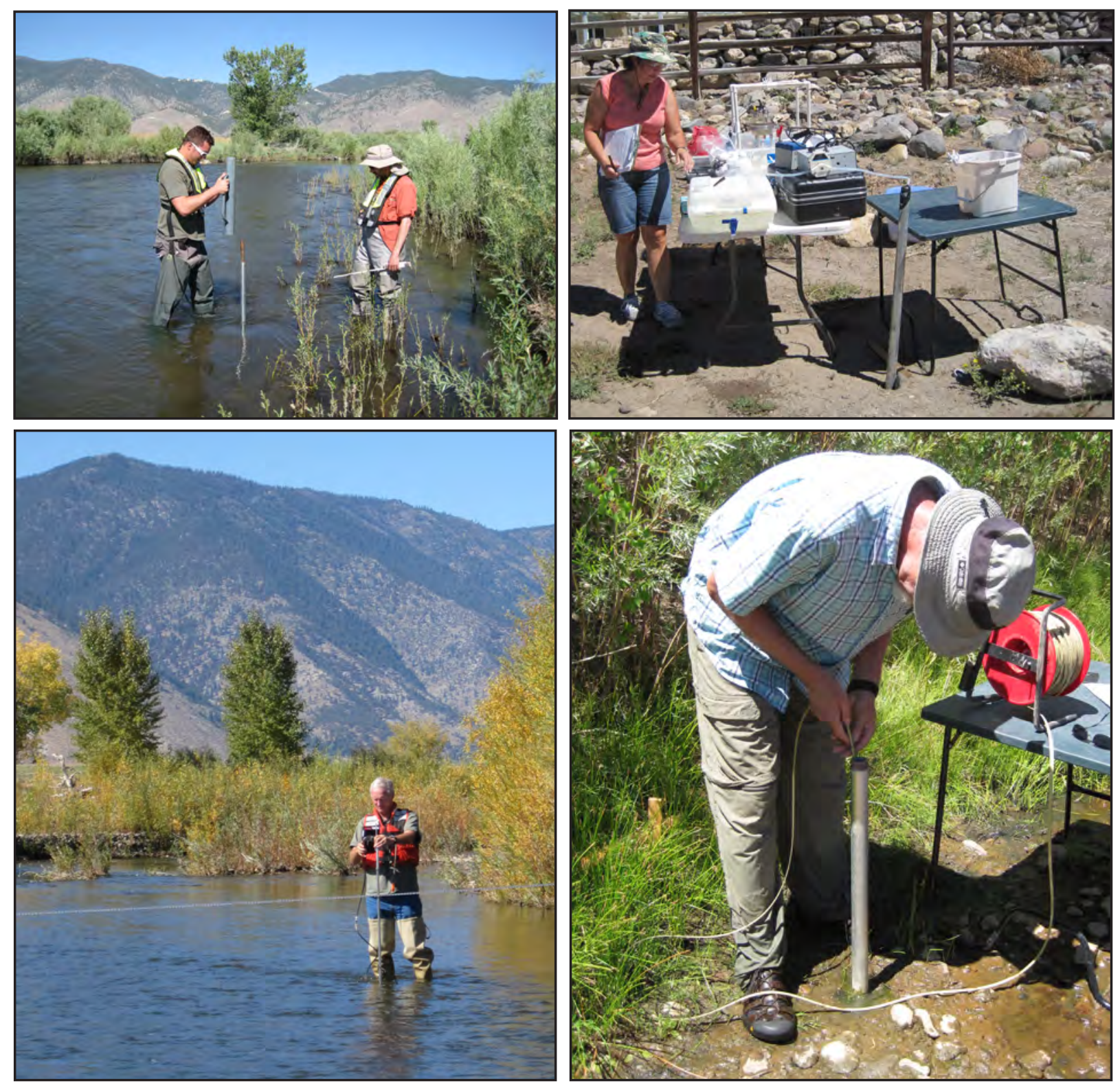